Portland State University

PDXScholar

$1-1-2011$

\title{
Scratched Petroglyphs in the Bennett Hills, Idaho
}

Karla Lucille Hambelton

Portland State University

Follow this and additional works at: https://pdxscholar.library.pdx.edu/open_access_etds Let us know how access to this document benefits you.

\section{Recommended Citation}

Hambelton, Karla Lucille, "Scratched Petroglyphs in the Bennett Hills, Idaho" (2011). Dissertations and Theses. Paper 329.

https://doi.org/10.15760/etd.329

This Thesis is brought to you for free and open access. It has been accepted for inclusion in Dissertations and Theses by an authorized administrator of PDXScholar. Please contact us if we can make this document more accessible: pdxscholar@pdx.edu. 
Scratched Petroglyphs in the Bennett Hills, Idaho

by

Karla Lucille Hambelton

A thesis submitted in partial fulfillment of the requirements for the degree of

Master of Arts

in

Anthropology

Thesis Committee:

Kenneth M. Ames, Chair

Jeremy Spoon

Virginia L. Butler

Portland State University

2012 


\begin{abstract}
This study examines rock art sites containing scratched petroglyphs in the Bennett Hills, Idaho. Despite their research potential, scratched petroglyphs have received little attention in rock art research or literature. This study contributes valuable data to scratched rock art research and the corpus of rock art research in general. Two samples of ten scratched petroglyph sites were examined and recorded for a total of twenty petroglyph sites. Using formal and contextual research methods, multiple attributes of scratched petroglyphs are identified and analyzed. The formal qualities of scratched petroglyphs are examined to define the extent and to characterize the motif assemblage. Formal qualities were also studied to test hypotheses concerning the relationship between scratched and pecked petroglyph styles and associations between scratched petroglyphs and other archaeological phenomena. The contexts of scratched petroglyphs are studied on site and landscape scales to identify correlations with other archaeological phenomena and environments.
\end{abstract}

The formal analyses revealed that there are more scratched petroglyphs in the Bennett Hills than records and literature currently indicate. Few site records document the presence of scratched petroglyphs, although as a result of this analysis it appears to be ubiquitous in the Bennett Hills. It is possible that scratched petroglyphs are under recorded in other locales as well, and that further investigations may identify a greater frequency of scratched petroglyphs throughout the Great Basin. Proper identification of 
scratched petroglyphs may alter how these properties are evaluated and in turn how they are managed. The Bennett Hills encompass a limited and unique assemblage of scratched petroglyph motifs that are dissimilar to petroglyphs manufactured using other techniques. This is significant in that it helps support the idea that scratched petroglyphs are distinct. Rather than just an alternative method to pecking, scratched petroglyphs serve a unique function that is different from and independent of pecked petroglyphs. Contextual analyses indicated that scratched petroglyphs are located in patterned and significant associations with artifacts, features, environments, and landscapes. The contextual analysis suggested that scratched rock art was produced in a public context in close proximity to subsistence related activities, perhaps in association with resource gathering events.

There are various hypotheses that deal with the interaction between scratched and pecked petroglyph styles. Scratched petroglyphs occur both independent of and in association with other pecked petroglyph styles, although scratched petroglyphs do not commonly occur with any one pecked motif. When scratched and pecked petroglyph styles overlap scratched petroglyphs are always later than and superimposed over earlier pecked petroglyphs. Data was collected to test three hypotheses concerning the intention of association between scratched and pecked petroglyphs. It does not appear that scratched petroglyphs serve to obliterate earlier pecked petroglyphs or function as a sketch that would be pecked later. There is evidence that some scratched petroglyphs enhance earlier pecked petroglyphs however, this hypothesis cannot sufficiently describe the range of patterns and associations found in the Bennett Hills scratched petroglyph 
assemblage. Hypotheses suggesting associations between scratched rock art and other archaeological phenomena were also examined. The association between scratched petroglyphs and scratched stones is deserving of further research. It may also be too soon to dismiss the association between scratched petroglyphs and quartz. The examination of scratched petroglyphs in the Bennett Hills provides a unique insight into the minds of the makers of these petroglyphs, contributing valuable data our knowledge of the prehistoric peoples of the Bennett Hills and surrounding areas. 


\section{Acknowledgements}

I would like to thank the following individuals and organizations for their invaluable guidance and support: Ken Ames, Virginia Butler, Jeremy Spoon, Lisa Cresswell, Carolynne Merrell, Jim Keyser, the Oregon Archaeological Society, Gene Titmus, John Fagan, Joe Reese, Anna Prentiss, George Poetschat, Teacie Hambelon, Bob Hambelton, John Hambelton, Carissa Hambelton, Kristen Fuld, Daniel Medders, Kristin Murdoch, and Scott Slowinski. I remain responsible for all statements of opinions and errors of fact. 


\section{Table of Contents}

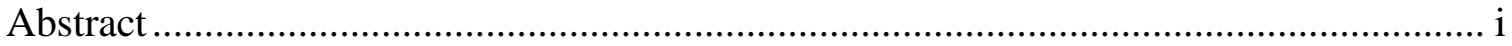

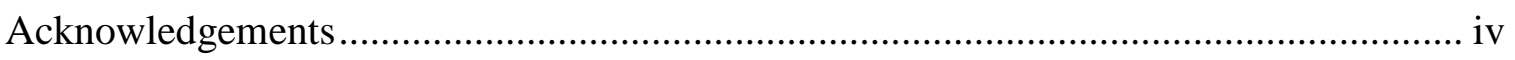

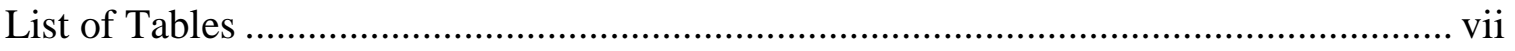

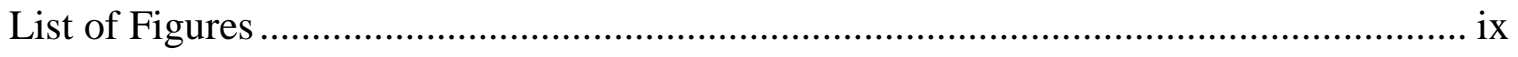

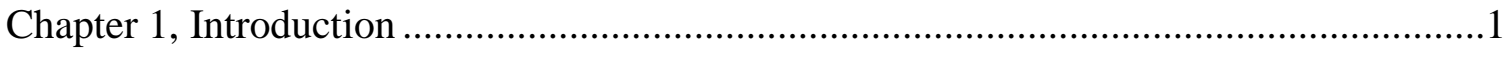

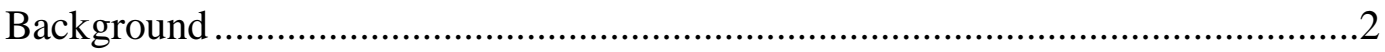

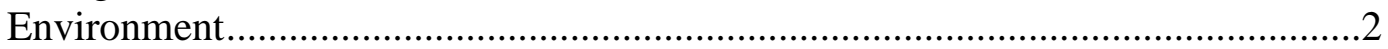

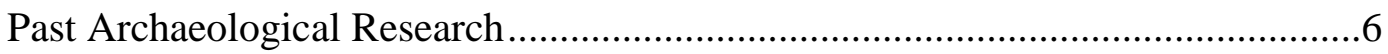

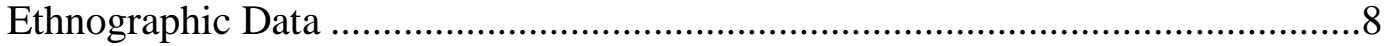

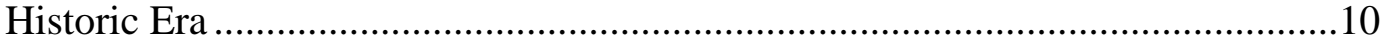

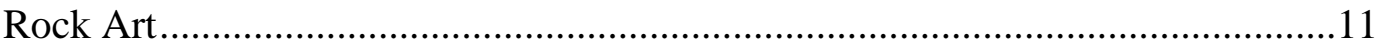

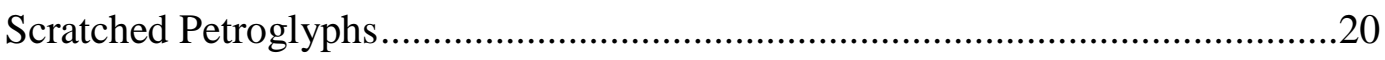

Chapter 2, Hypotheses and Methods ..........................................................................26

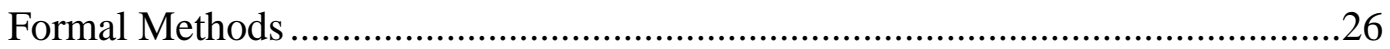

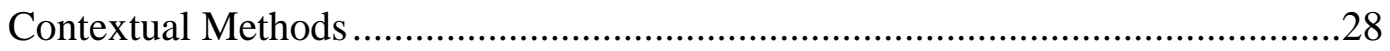

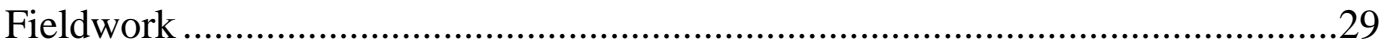

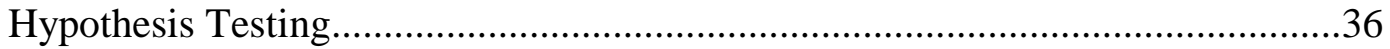

Associations between Scratched and Pecked Petroglyphs.....................................36

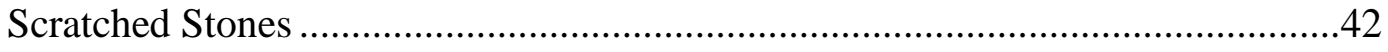

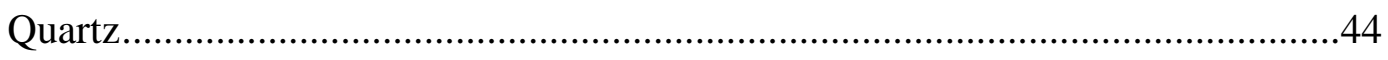

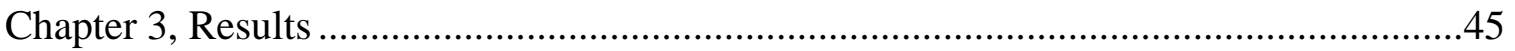

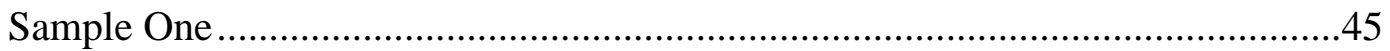

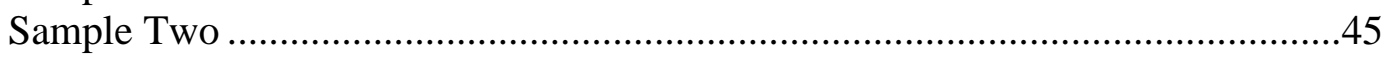

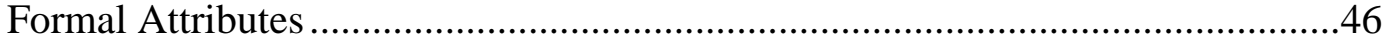

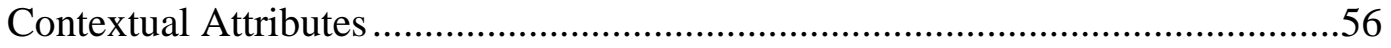

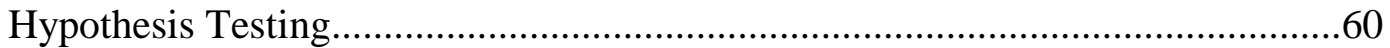

Associations between Scratched and Pecked Petroglyphs......................................60

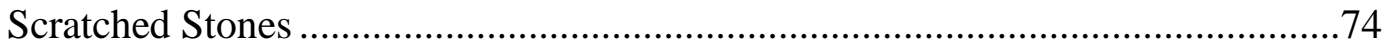


Assemblage 1, Huntley and Nance (1976), Plew (1976), and Arkush (2011).......75

Assemblage 2, Santini (1974) Collection ...........................................................81

Assemblage 3, Thomas (1983) Gatecliff Rockshelter Collection ........................87

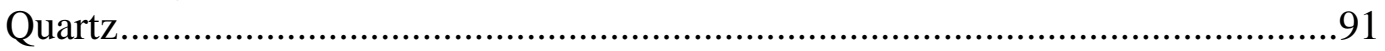

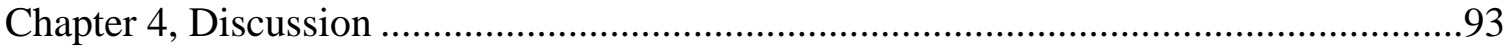

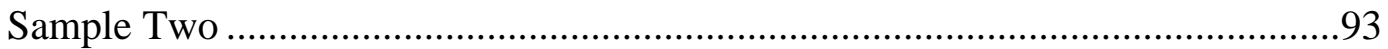

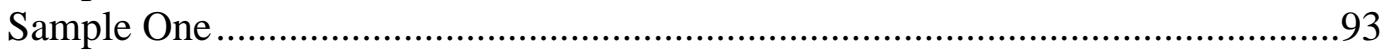

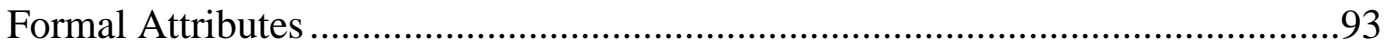

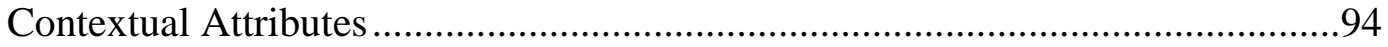

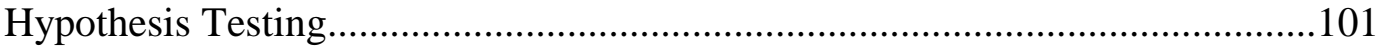

Associations between Scratched and Pecked Petroglyphs.................................101

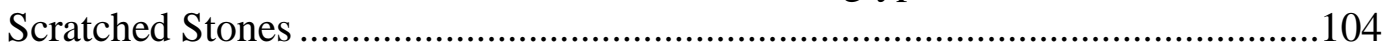

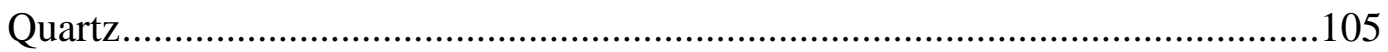

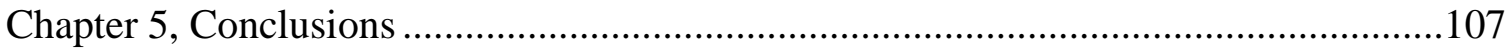

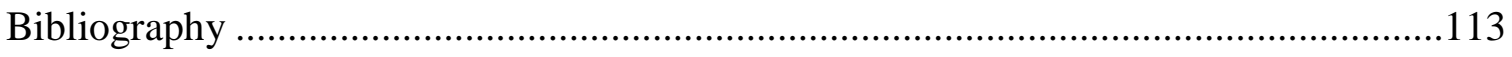

Appendix A, Scratched Petroglyph Tracings........................................................132

Appendix B, Scratched Petroglyph Survey Form .................................................213

Appendix C, Issues with Using Munsell Color Charts to Determine Relative Repatination

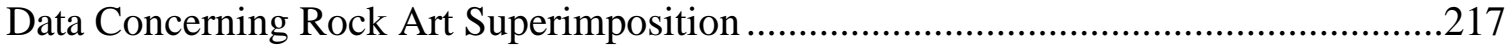




\section{List of Tables}

Table 3.1. Description of Scratched Motif and Figure Reference

Table 3.2. Scratched Petroglyph Motifs in the Bennett Hills .52

Table 3.3. Quantity of Scratched and Pecked Petroglyph Panels at Each Site in the Bennett Hills .56

Table 3.4. Scratched Petroglyph Site Data .57

Table 3.5. Artifact and Feature Association with Scratched Petroglyph Panels in the Bennett Hills .59

Table 3.6. Aspect of Scratched Petroglyph Panels in the Bennett Hills .59

Table 3.7. Inclination of Scratched Petroglyph Panels in the Bennett Hills .60

Table 3.8. Impacts at Scratched Petroglyph Panels in the Bennett Hills .60

Table 3.9. Pecked and Abraded Petroglyphs Associated with Scratched Petroglyphs......62

Table 3.10. Association and Superimposition between Scratched and Abraded or Pecked

Petroglyphs .63

Table 3.11. Comparative Percentages of the Crosshatch, Parallel Line, and Plant-like Motifs. .80

Table 3.12. Description of Santini Motifs .86

Table 3.13. Santini Design Elements Present in Bennett Hills Scratched Petroglyph Assemblage

Table 3.14. Percentage of Scratched Motifs in the Gatecliff Collection and the Bennett

Hills $.89,90$

Table 3.15. Manufacturing Techniques in the Gatecliff Collection and the Bennett Hills... 


\section{List of Figures}

Figure 1.1. Study area, the Bennett Hills and petroglyph sites .......................................

Figure 1.2. Map of Tribal Territories in the Great Basin ...............................................

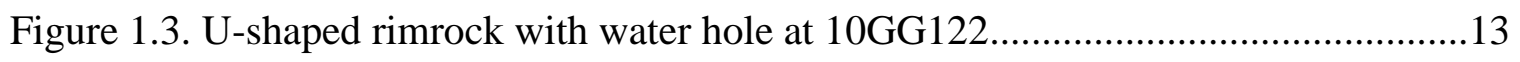

Figure 1.4. 10GG284, View shed from petroglyphs, facing south, illustrating a wide field of vision, aesthetic panorama, and a unique geologic feature ......................................14

Figure 1.5. 10GG33, Great Basin Representational style ...........................................16

Figure 1.6. 10GG33, Great Basin Pecked Abstract Style, curvilinear.............................16

Figure 1.7. Great Basin Pecked Abstract Style, rectilinear...........................................17

Figure 1.8. 10GG783, Great Basin Scratched Style .................................................17

Figure 1.9. Tom's Spring, Great Basin Carved Abstract style (Merell and Dorn 2009) ...18

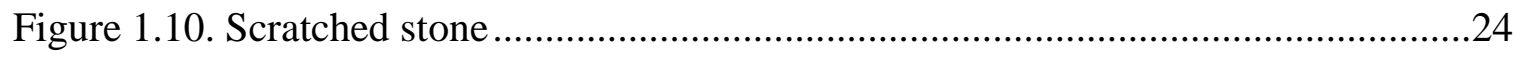

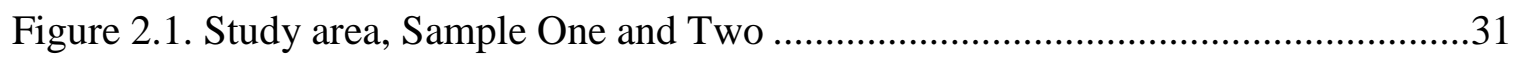

Figure 2.2. 10GG122, associated scratched and abraded petroglyphs ............................39

Figure 2.3. 10GG122, non-associated scratched petroglyph .......................................39

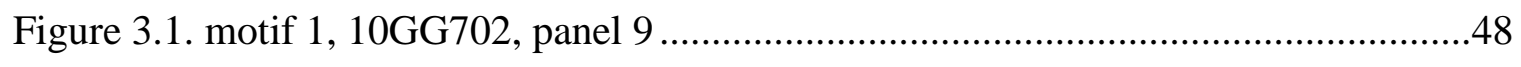

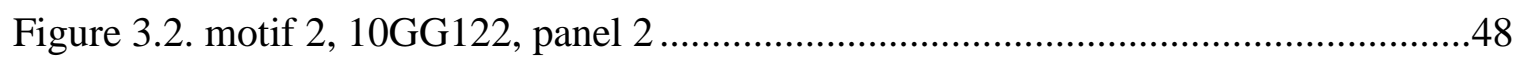

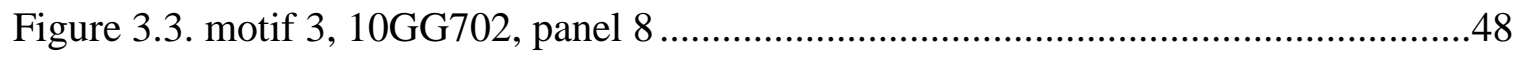

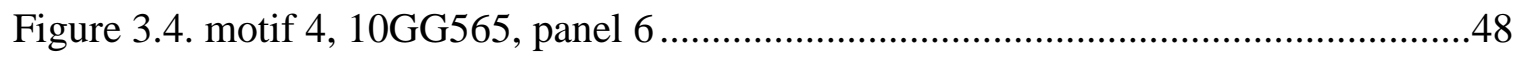

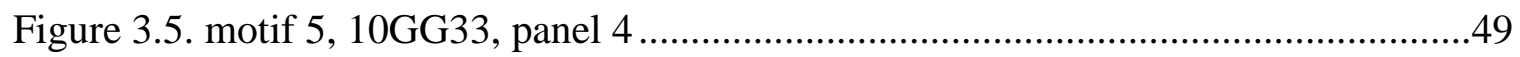

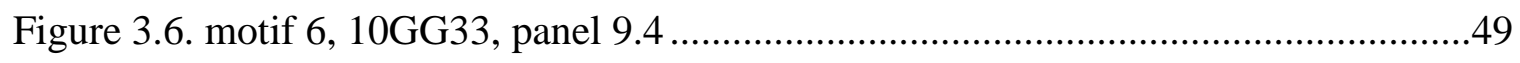

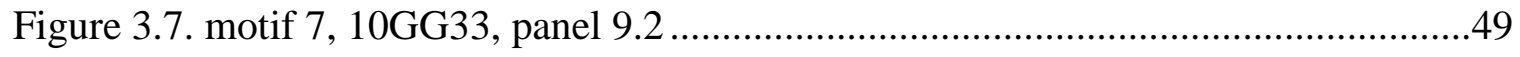




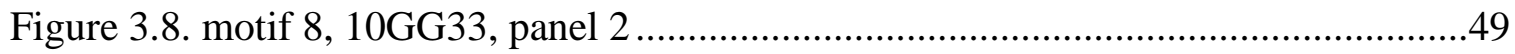

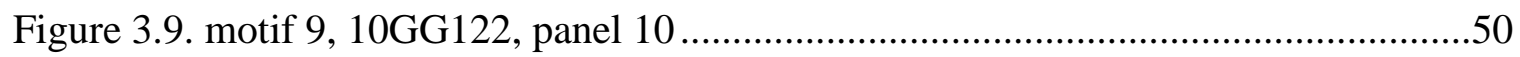

Figure 3.10. motif 10, 10GG33, panel 9.6 ……………...........................................50

Figure 3.11. motif 11, 10GG565, panel 14 ……………..............................................50

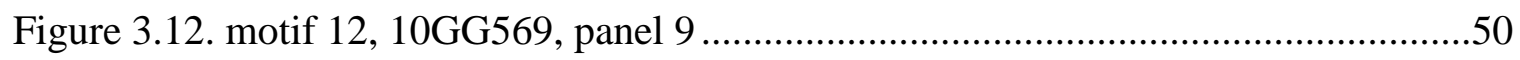

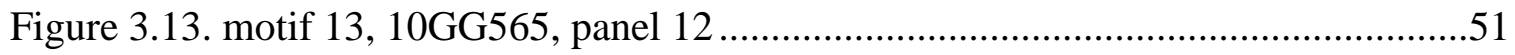

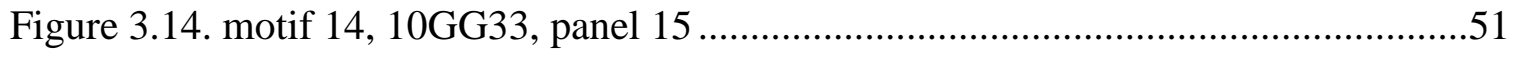

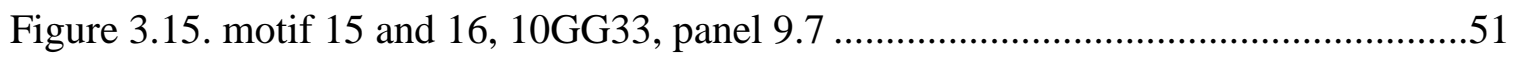

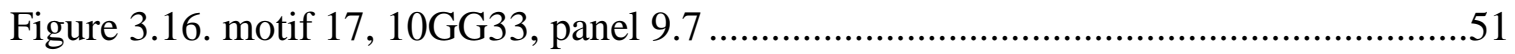

Figure 3.17. 10GG284, distinctive scratched petroglyph ...............................................53

Figure 3.18. 10-GG-565, panel 2, example of the standard width and depth of scratched

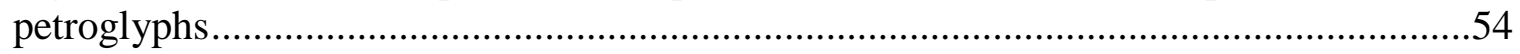

Figure 3.19. 10-GG-702, panel 6, example of a deep and thin scratched petroglyph .......54

Figure 3.20. 10GG33, panel 1, example of a shallow and wide scratched petroglyph......55

Figure 3.21. 10GG165, scratched petroglyph associated, but not superimposed over pecked representational petroglyph ...........................................................................64

Figure 3.22. 10GG122, scratched petroglyph $>50 \%$ superimposed over indistinct Abrasion.

Figure 3.23. 10GG569 scratched petroglyph < 50\% superimposed over a pecked curvilinear petroglyph

Figure 3.24. 10GG122, scratched petroglyph 100\% superimposed over a pecked rectilinear petroglyph

Figure 3.25. 10GG565, panel 3. A pecked vertical line with radiating scratched lines towards the bottom of the pecked motif .66

Figure 3.26. 10GG565, panel 7. Two pecked representational human figures. The arms and legs on both figures are embellished with scratches 
Figure 3.27. 10GG565, panel 8. A pecked motif resembling the body and neck of an animal. Within the body of the animal there are nine scratched vertical lines parallel to one another.

Figure 3.28. 10GG122, panel 11. A pecked abstract curvilinear motif. Scratched are traced over the pecked motif.

Figure 3.29. 10GG783, panel 3. An abstract pecked motif with radiating scratched lines. This association looks similar to panel three at 10GG565

Figure 3.30. 10GG33, panel 7. An abstract circular-shaped abraded motif with scratches radiating from the top and bottom of the circle.

Figure 3.31. 10GG33, panel 8. A representational human figure with a headpiece. There are many scratches radiating off the bottom of the head piece

Figure 3.32. 10GG33, panel 9.5. A representational shield figure with a phallic appendage embellished with three vertical and parallel scratches

Figure 3.33. 10GG33, panel 12. A pecked abstract curvilinear motif with many scratches

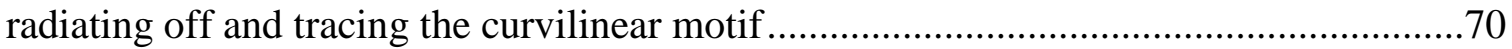

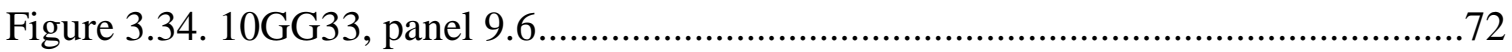

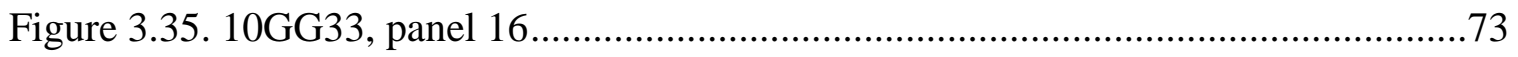

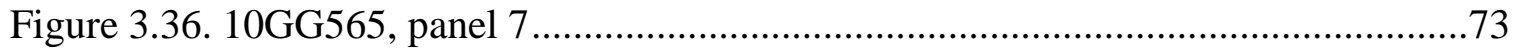

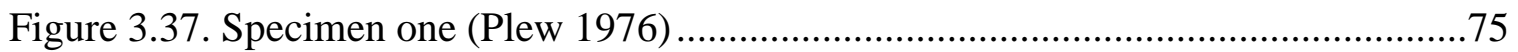

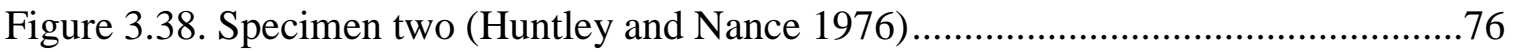

Figure 3.39. Specimen three (Huntley and Nance 1976) ...........................................77

Figure 3.40. Specimen four (Huntley and Nance 1976) .............................................78

Figure 3.41, Nine scratched stones from Trapper Cliff, southeast Idaho (Arkush 2011)..79

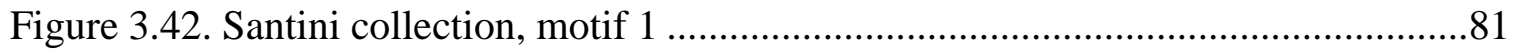

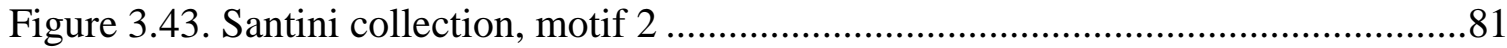

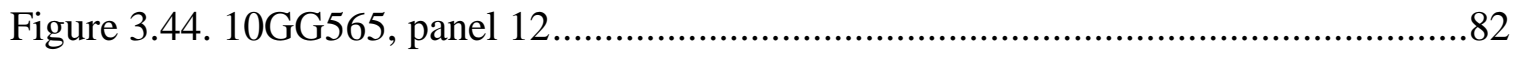

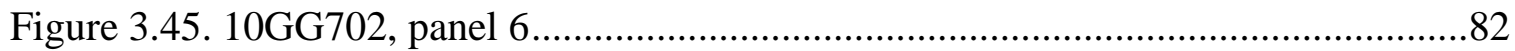




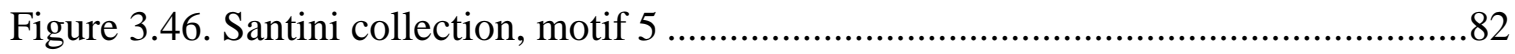

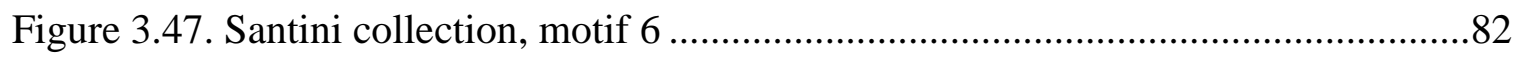

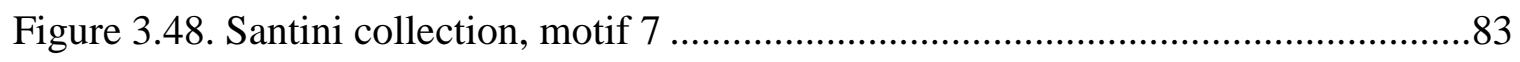

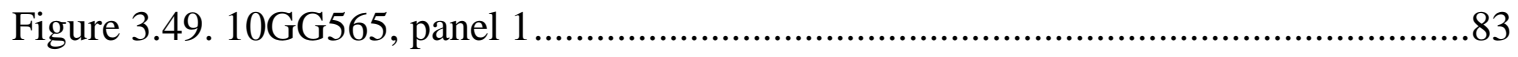

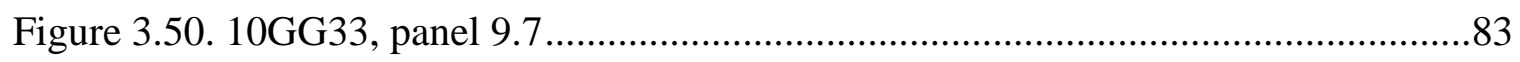

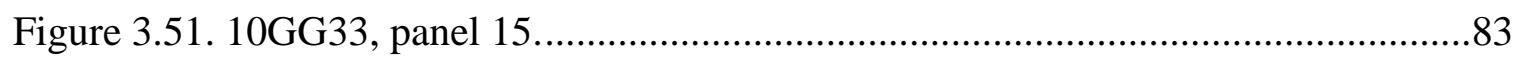

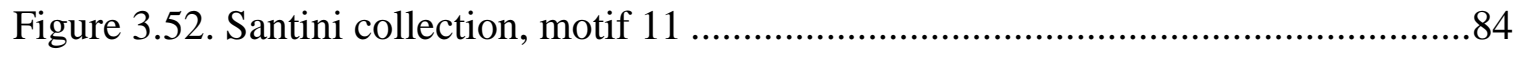

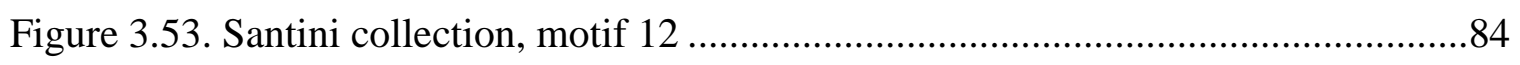

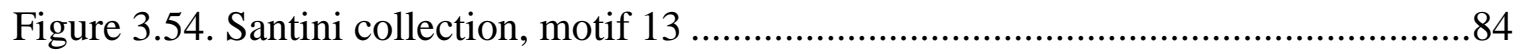

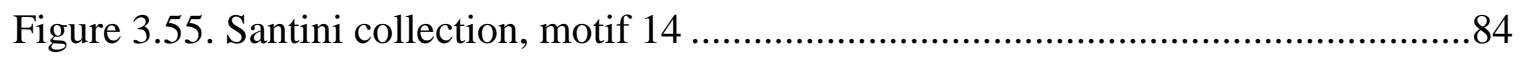

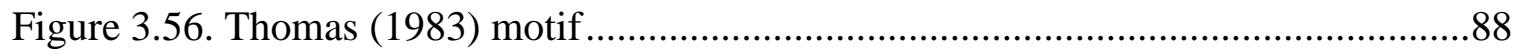

Figure 4.1. 10GG565, panel 12, scratched petroglyph possibly representing a feather,

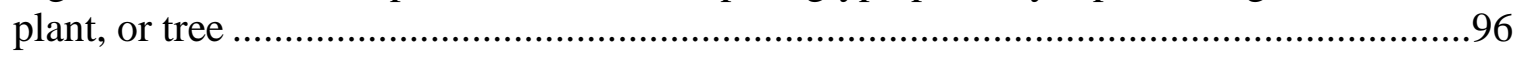




\section{Chapter 1, Introduction}

The Scratched Rock Art Style as defined in the Great Basin rock art typology (Heizer and Baumhoff 1962) is a unique petroglyph style with an unusual manufacturing technique, wide geographic distribution, and characteristic motifs. Scratched petroglyphs are thought to reflect nonmaterial concepts and ideologies not necessarily represented in other rock art styles or aspects of the archaeological record (Schaafsma 1985). Despite their research potential, scratched petroglyphs have received little attention in rock art research or literature in comparison to other rock art related studies. Syntheses of limited data (Stoney 1994; Christensen 1992; Ritter 1994; Hedges 1989) have identified patterns and produced hypotheses about its interpretation but these hypotheses have not been adequately tested.

The main goal of this research was to gain a better understanding of scratched petroglyphs in the Bennett Hills. Scratched rock art data were collected from a representative sample of 63 previously recorded rock art sites in the Bennett Hills of south central Idaho. The Bennett Hills are rich in prehistoric cultural resources including extensive rock art. Using formal and contextual analyses, multiple attributes of scratched petroglyphs are identified and analyzed. This study attempts to define the physical characteristics of scratched petroglyphs and establish how many there are within the study area. Formal analyses are used to quantify the extent and characterize the motif assemblage of scratched petroglyphs in the Bennett Hills. This study also aims to 
establish where scratched petroglyphs are located. The contexts of scratched petroglyphs are studied on multiple scales to identify associations with other archaeological phenomena, environments, and landscapes. This study also examines the relationship between scratched and pecked petroglyph styles. Associations between scratched and pecked petroglyphs are investigated concentrating on the quantity of scratched petroglyphs that are associated with pecked petroglyphs, the temporal order of these two styles, and if scratched petroglyphs are associated with a specific pecked motifs. Data was also collected to test three hypotheses concerning the intention of association between scratched and pecked petroglyphs. Scholars have identified that scratched petroglyphs serve to obliterate earlier pecked petroglyphs, function as a sketch that would be pecked later, and enhance earlier pecked petroglyphs. Last two hypotheses suggesting associations between scratched rock art and other archaeological phenomena were also examined. This analysis tested the possibility that scratched petroglyphs are manufactured with quartz tools. Similarities between scratched petroglyphs and scratched stones from the Great Basin are also considered. This research contributes valuable data to the rich yet understudied concentration of rock art in the Bennett Hills and adds valuable data to our limited understanding of scratched petroglyphs.

\section{Background}

\section{Environment}

The Bennett Hills study area is in south central Idaho in western North America (figure 1.1). The Bennett Hills are located at the conjunction of three major physiographic regions; the Great Basin, the Colombia Plateau, and the Rocky Mountains. 


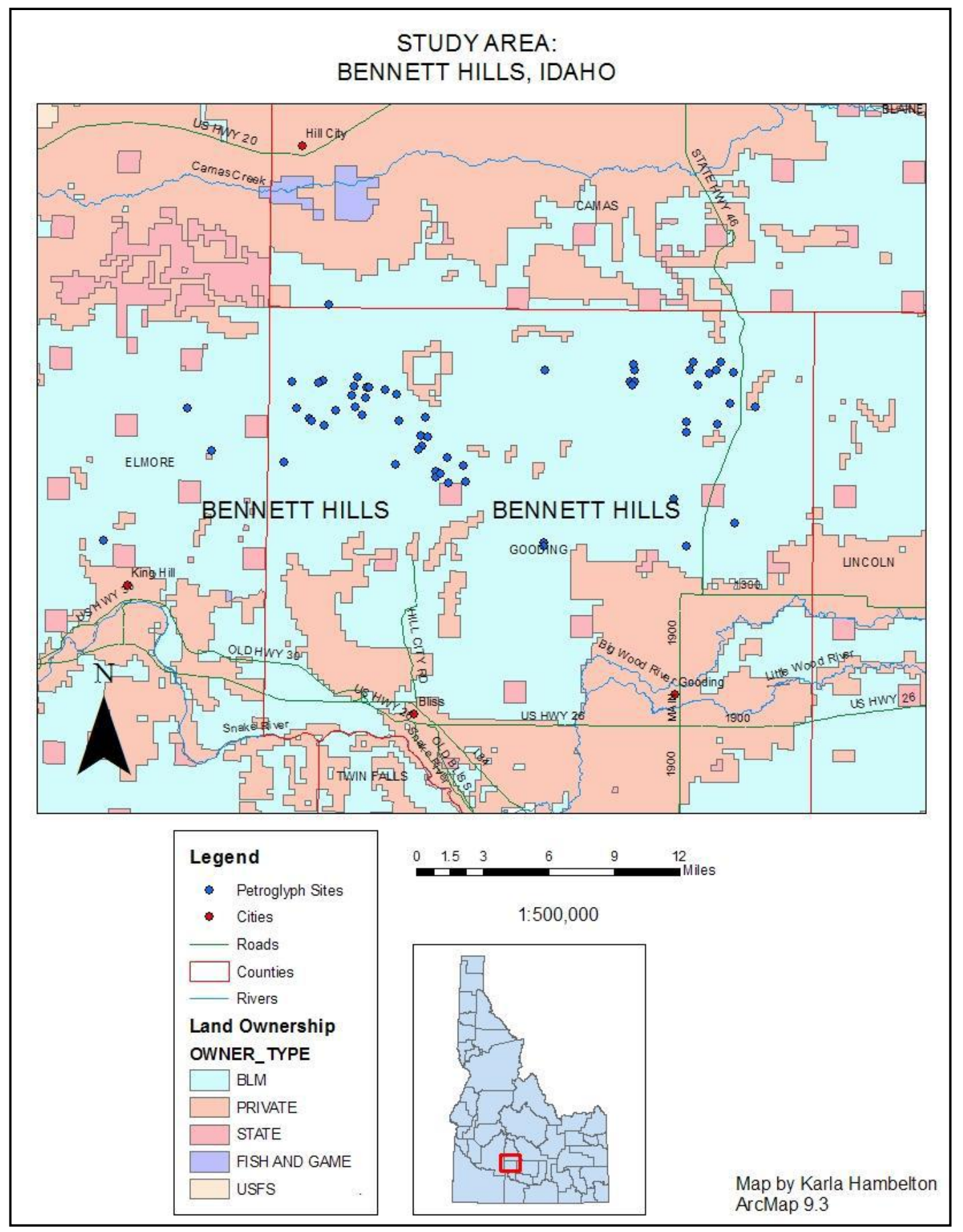

Figure 1.1. Study Area, the Bennett Hills and Petroglyph Sites. 
Cultural and environmental attributes of the Bennett Hills are most consistent with patterns found in the Great Basin, although there are clear influences from other regions. The study area is an environmental and geographic transitional zone between the Rocky Mountains to the north and the Snake River Plain to the south. The Bennett Hills span roughly 70 miles from east to west and 15 miles north to south. Ownership of the study area is dominated by the Federal government administered by the Bureau of Land Management (BLM) with limited state and private land. All the archaeological sites examined as part of this research are located on lands managed by the BLM.

The southern slopes of the Bennett Hills rise gradually out of the central Snake River plain. The north facing slopes rise steeply from the Camas Prairie, located just north of the hills. The Bennett Hills are often flat at higher elevations, resembling a mesa in some places rather than hills. The mountains north of the Camas Prairie extend into the northwestern Rocky Mountains, a vast mountainous area covering most of central Idaho.

The Camas Prairie is fertile, comprised of relatively deep soils in contrast with the Bennett Hills. Extensive columnar rhyolite, block faulted and eroded basalts, and welded tuff dominates. Many boulders, cobbles, and pebbles occur in a matrix of basaltic sand, termed "melon gravels" (Malde et al. 1963). Soils are shallow and the landscape is very rocky, punctuated by mesas and canyons. The extensive columnar rhyolite and basalt within the study area provides many quality surfaces for the production of petroglyphs. Elevation varies considerably within the project area. The Snake River plain averages roughly $762 \mathrm{~m}$ asl, Mount Bennett is 2,267 $\mathrm{m}$ asl at the summit, and the Camas Prairie averages $1,493 \mathrm{~m}$ asl. 
The Snake River and its major local tributaries, the Big Wood River and the Little Wood River, are the largest perennial water bodies in the region. There are seven major creeks within the study area fed by springs, seeps, and snow melt that hold ephemeral water. Precipitation ranges between 25 and $38 \mathrm{~cm}$ annually. Most of the precipitation falls as snow during the winter months. Typically the winters are moderately cold. Summers are hot and dry. Flowing water dries up in the mid to late summer months depending on the year. From roughly July to October creeks are mostly dry with the exception of pools of water in catch basins. Many sites in the Bennett Hills are located along creeks and drainages that hold ephemeral water suggesting wetter conditions when these sites were occupied in the past (Cinadr 1976). Water sources are important in determining how the area was used in the past. Small open camp sites often cluster around ephemeral catch basins, springs, and creeks indicating these features served as important water sources in the Bennett Hills (Cinadr 1976).

The Bennett Hills are within the Northern Great Basin Biotic Area (Davis 1939). The study area is inhabited by a variety of small and large mammals, birds, reptiles, and a few amphibians. The study area is dominated by xerophytic vegetation. This type of biota is adapted to survive in arid regions often dominated by sagebrush (Artemesia tridentate), rabbitbrush (Chrysothamnus nauseosus), and bitterbrush (Purshia tridentate). There are other micro-environmental niches found within the Northern Great Basin Biotic Area that contain distinct flora and fauna. Associations deemed important to the area archaeology located within the Bennett Hills include marsh, meadow, prairie, chaparral, deciduous forest, and coniferous forest. These micro-environmental niches contain plants, animals, 
and other resources that were important to Shoshone, Bannock, and Northern Paiute peoples.

Flora and fauna have changed dramatically in recent history due to overhunting, fire management, grazing, climate change, and encroaching development. Recent changes in flora and fauna make it difficult to correlate the location of prehistoric sites with current environmental observations (Cinadr 1976). It is essential to consider dramatic changes in landscape through time. Paleoenvironmental and archaeological data can help reconstruct past environments.

\section{Past Archaeological Research}

Despite there being great potential for research in the Bennett Hills, there have been few studies focused on rock art in the area. Most of the archaeological sites containing petroglyphs were recorded by BLM employees as part of section 106 and section 110 compliance and were not incorporated into any larger research projects. Many rock art sites were recorded as part of the Idaho State University Museum, Mt. Bennett Hills Project during the 1974 and 1975 field seasons (Cinadr 1976). Although the project recorded many petroglyph sites, rock art was not a focus of the research, thus there are little data or discussions of petroglyphs in the Bennett Hills besides the site forms.

More recently, Carolynne Merrell and Ronald Dorn (Merrell and Dorn 2009, Merrell 2007) conducted research at three Bennett Hills petroglyph sites and other rock art sites throughout southern Idaho. Their work focused on recordation, mapping, dating, and petroglyph typology. Because little rock art research has been conducted in the 
Bennett Hills, research from other areas containing comparable rock art (eg. Plew 1996; Ritter 1994; Cannon and Ricks 2007; Leen 1988) is critical in this study.

Lisa Cresswell, BLM Archaeologist, examined root and berry processing in the Bennett Hills (Cresswell 2008). Testing groundstone for pollen residue she found that grasses, sage, yampa, biscuitroot, and plants from the mint and sunflower family were collected and processed in the Bennett Hills. Small circular rock features may have served as caches or root collecting pits, particularly when they are associated with groundstone and root gathering areas (Cresswell 2008). She also notes that groundstone is commonly located at sites containing rock art.

In 2008 University of California, Bakersfield crews excavated four 1x1 m test units at Calf Creek Oasis (10GG122, included in Sample One of this study). This site is located at a U-shaped rimrock feature with a small waterhole. This limited excavation yielded 26 small biface fragments, two scrapers, an Eastgate projectile point, a high density of mostly tertiary reduction phase flakes $\left(6,100\right.$ flakes from $.3 \mathrm{~m}^{3}$ of soil), two thin walled grey ware pottery shards, and a hearth feature (Decarlo 2008). Charcoal from the hearth dated to 510 to 420 cal B.P. Bighorn sheep was identified from stone tool tested for protein residue. Nineteen petroglyph panels are located in close proximity to the test excavations, thirteen of which display scratched petroglyphs. Unfortunately, rock art was not included as part of the preliminary site analysis.

As a result of the most complete survey of the Bennett Hills (Cinadr 1976) six site types were identified; open sites, micro-open sites, quarry sites, petroglyph/pictograph sites, cave/rockshelter sites, sites with rock structures, and historic sites. Winter village 
sites were also identified along the Snake River. Based on pedestrian surveys of the surface alone, open lithic scatters representing small campsites are the most common site type in the Bennett Hills (Cinadr 1976).

Archaeological data suggest Native American peoples occupied the Bennett Hills from the late Pleistocene up until the contact era. Ranges of projectile point styles found in the Bennett Hills suggest a long span of occupation in the area (Cinadr 1976). However, due to the difficulty in dating rock art, it is unclear how long Native American inhabitants have produced rock art in the region.

\section{Ethnographic Data}

Julian Steward's ethnographic work contributed valuable data concerning the region, Native American peoples, the contact era, the Snake River Shoshone, and the Northern Paiute (Steward 1938). Northern Paiute peoples lived within the western regions of the Snake River in southern Idaho, while the Snake River Shoshone lived throughout the Snake River plain. Snake River Shoshone were a mix of Northern Shoshone and Bannock peoples. Linguistically the Bannock are more closely related to the Northern Paiute than the Northern Shoshone (figure 1.2). Both Snake River Shoshone and Paiute were bilingual and performed activities together (Walker 1971).

Steward (1938) identified a seasonal round subsistence pattern among the Snake River Shoshone and the Northern Paiute peoples. Winters were spent in encampments or small villages along the Snake River. Spring time salmon runs attracted people to the Snake River. Small scale gathering activities also occurred along the Snake River in the spring. After the salmon runs people moved to the Camas Prairie to gather camas and 
engage in trade with other groups. The Lemhi, Shoshone-Paiute, and Nez Perce traveled long distances to trade and gather resources on the Camas Prairie (Steward 1938).

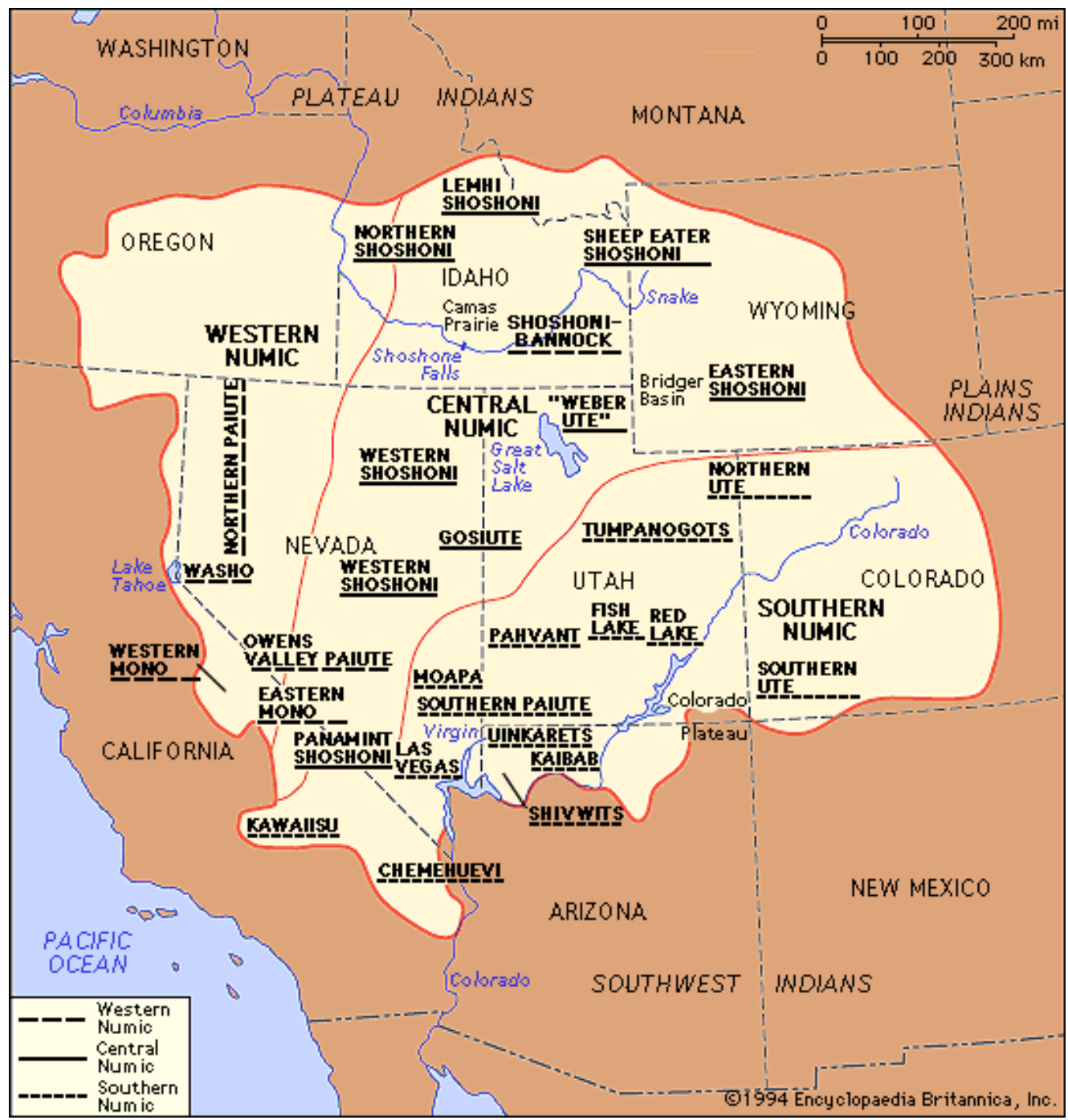

Figure 1.2. Map of Tribal Territories in the Great Basin.

A final salmon run occurred in the fall after which people would return to their winter village or encampment. This $240 \mathrm{~km}$ round trip took them through the Bennett Hills twice. Here chokecherries, sunflowers, yampa, camas, and other roots were gathered. In addition to plant foods, the region also supplied both small and big game, lithic raw material, and apparently stimulated the creation of a plethora of rock art. 


\section{Historic Era}

Basque sheepherders and cattle ranchers had and continue to have a major impact on the natural and cultural resources in the area. There are historic herding camps, homesteads, and ranches in the Bennett Hills. Basque sheepherders and ranchers are also responsible for the production of some rock art in the area. At 10GG30 and 10GG102 petroglyphs and pictographs have been identified and attributed to Basque herders. At 10GG30 the presence of Basque sheep herders is indicated by the petroglyph "Gora Euskadi” (long live independent Basque country) accompanied by a swastika symbol (Merrell 2007). Basque rock art is easily distinguishable from Native American rock art. Basque rock art often includes a name, date, birthplace, and some type of symbology. Both Native American and Basque rock art often occur at the same site location so it is important to be able to differentiate. Early ranchers also produced petroglyphs in the Bennett Hills. Brand rock, located within the study area, is a large boulder covered by 145 carved cattle brands (Merrell and Rodman 2005).

The Basque also constructed rock piles, walls, and circles. Various interpretations are offered on the function and meaning of these features. Historic rock features possibly mark limits of range for sheep (White and Malouf 1963), alleviate boredom (Georgette 1965; Douglas 1973), mark graves (White and Malouf 1963), mark mining claims (White and Malouf 1963), and cover garbage. Prehistoric rock features are often straight, semicircular, circular, cairns, and talus pits. Suggested purposes for prehistoric rock structures include hunting blinds (Touhy 1963), root caches or collecting pits (Cresswell 2008), structures, and components of religious ceremonies (Ray 1963; Minor et al. 1979; Aikens 
1993; Daehnke and Raymond 2008). It can be extremely difficult to differentiate between historic and prehistoric rock features, particularly since many sites in the Bennett Hills have both historic and prehistoric site components. At least some of these structures appear to be historic as indicated by the absence of lichens on exposed surfaces of the stacked rocks.

\section{Rock Art}

As of September 2008 there were 63 recorded rock art sites in Gooding and Elmore counties (figure 1.1). These counties are unique and were selected for this research because they contain a high density of petroglyph sites with scratched rock art. Petroglyphs greatly outnumber pictographs in the study area. With the exception of the Great Basin Scratched style, petroglyphs are manufactured by pecking directly onto the rock surface using a stone chisel and hammerstone. A pictograph is a rock art motif that is painted or drawn using pigments. For the purpose of this study petroglyphs are recorded and organized spatially using panels and motifs. A rock art panel is defined as a natural rock cleavage, plane, or weathering surface on which rock art occurs (Whitley 2005). Rock art is commonly recorded using panels to organize space and distribution within a rock art site (Whitley 2005). A rock art panel is comprised of one or more rock art motifs. A rock art motif is a single petroglyph or pictograph image. Multiple motifs can be combined into more complex compositions.

Only one site (10GG10) contains pictographs and petroglyphs in comparison with 62 sites having only petroglyphs. There are two recorded sites (10LN61 and 10LN74) containing pictographs in Lincoln county, just east of the study area. At both sites the 
pictographs are located within lava tube caves. The pictographs at 10GG10 are located within a rock shelter. Merrell (2007) recognize a distinct distribution of petroglyphs and pictographs in this region. They found that pictographs are found in lava tube caves, while petroglyphs are located in above ground settings. Pictographs are thought to have been manufactured in this region sometime between the late archaic and the late prehistoric periods (Pavesic and Studebaker 1993). Petroglyphs can be significantly older, ranging from the late archaic to the late prehistoric (Merrell and Dorn 2009).

Scratched petroglyphs are not associated with pictographs in the Bennett Hills but they have been found in association with pictographs within Birch Creek Valley and Black Canyon Wilderness Study Area in southeastern Idaho (Merrell 2000, 2002, 2003), the middle fork of the Salmon River in central Idaho (Merrell 2004), Hells Canyon on the western boarder of Idaho (Leen 1988), and the Bruneau River in south central Idaho (Murphy 1994). These areas were historically occupied by peoples from the Shoshone, Bannock, and Paiute tribes, suggesting they were closely related to people who visited the Bennett Hills.

Rock art sites in the Bennett Hills cluster in association with specific physiographic and environmental features (Cinadr 1976; Hambelton 2008). The unprotected and steep north facing rock outcrops in the Bennett Hills are too uneven for rock art production, and thus petroglyphs are not commonly located on those slopes. Instead, petroglyphs almost exclusively occur on heavily varnished rock surfaces on the south facing slope of the Bennett Hills. Rimrock at the top and bottom edges of mesas are favored locations for the production of rock art. Rimrock is the sheer rock wall at the 
upper edge of a plateau, canyon, or geological uplift. In the Bennett Hills rimrock often occurs along the edges of a canyon, shallow drainages, and high terraces. The U-shaped rimrock with a water hole is a common geological feature in the Bennett Hills where many petroglyph sites have been previously located. The height of the rimrock can vary between 1 to $40 \mathrm{~m}$. An ephemeral drainage runs through the center of the U-shape. There is a small shallow pool of water at the base of the " $U$ " that lasts through the driest late summer months (figure 1.3). The "U" shaped rimrock feature often possesses strong acoustic properties. Scholars have identified that some rock art in western North America is located at sites with strong acoustic properties (Merell and Dorn 2009). Echoes may have been interpreted by Native American peoples as a means of communication with the spirit world (Waller 2011). Out of 63 rock art sites in the Bennett Hills 27 (43 percent) occur at U-shaped rimrocks with water holes (Hambelton 2008). Hambelton (2008) recognizes a strong association between rock art sites, close proximity to water, and specific elevation intervals 1,464 to 1,769 $\mathrm{m}$ asl in the Bennett Hills.

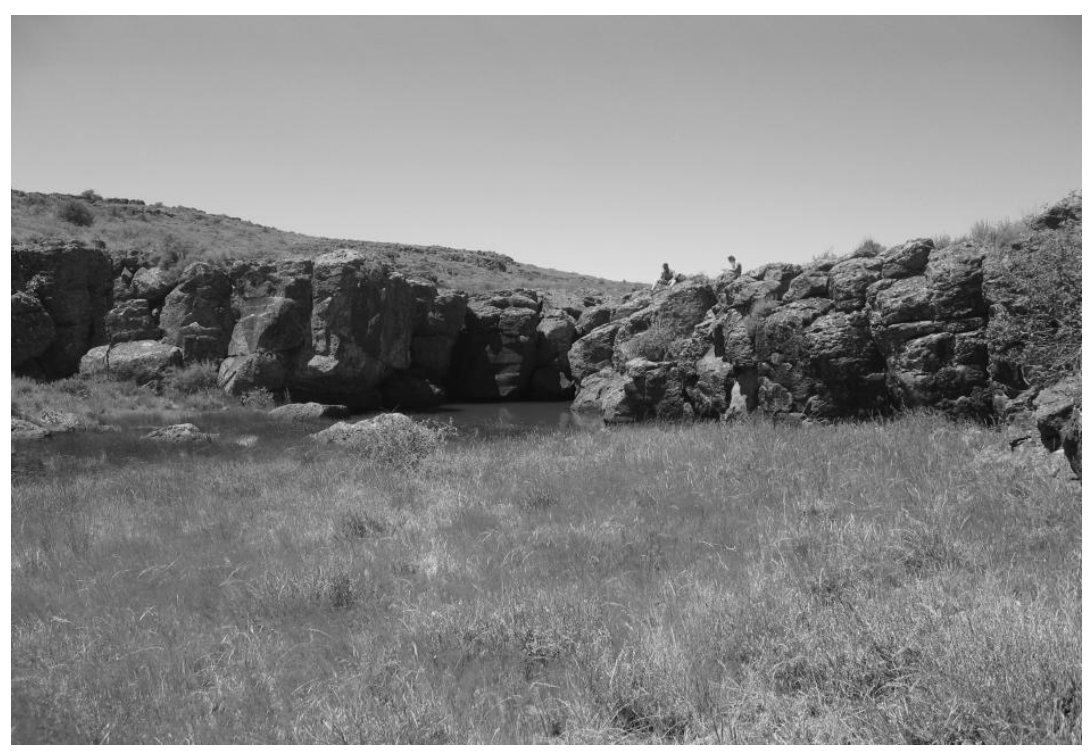

Figure 1.3. U-shaped rimrock with water hole at 10GG122. 
Rock art sites often occur at a location that provides a broad and or aesthetic view of surrounding terrain from and into the site, at springs, and at locations with distinctive geologic landforms (figure 1.4). Merrell (2005) recognizes that rock art sites in Idaho are located in relation to specific cultural and physical landscapes. Exceptional viewsheds, unique geologic and environmental features, and events occurring at specific locations imbue landscapes with cultural significance (Merrell 2005). Rock art is often located within these landscapes. This is consistent with the landscape symbolism model (Whitley et al. 2004). This model, drawn from ethnographies and oral narratives, examines the distribution of power on the landscape and how that effects the interaction between Native Americans and their physical surroundings. Rock art and other objects occur at specific locations as an expression of the power at that location (Whitley et al. 2004; David 2009)

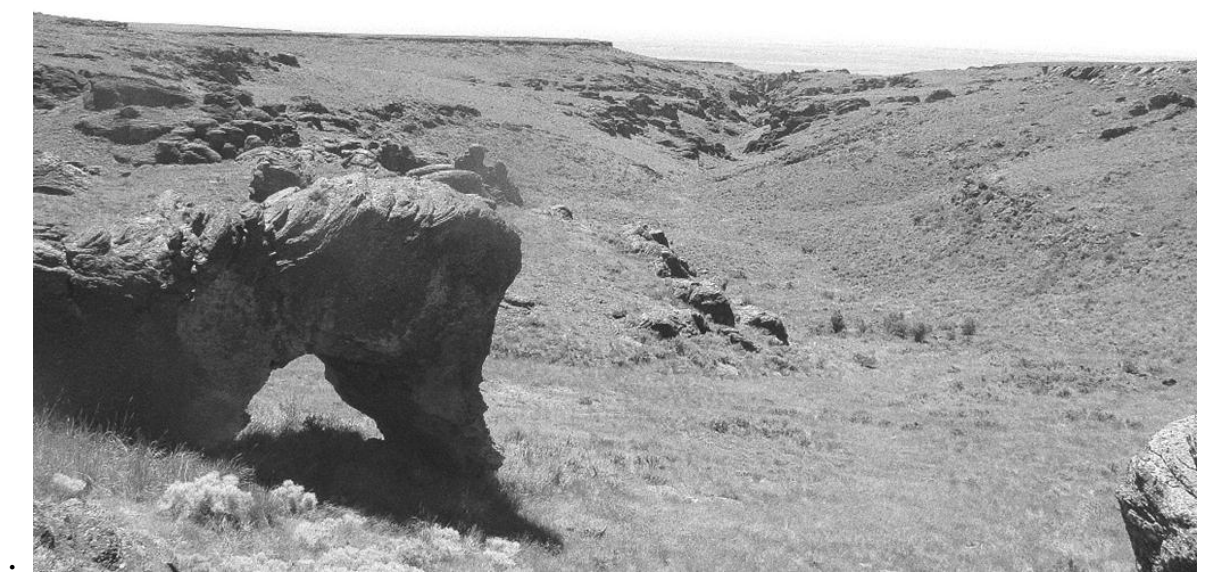

Figure 1.4. 10GG284, View shed from petroglyphs, facing south, illustrating a wide field of vision, aesthetic panorama, and a unique geologic feature. 
The rock art elements in the Bennett Hills are consistent with the Great Basin rock art tradition, although there are also clear influences of rock art traditions in other neighboring regions. For example, the shield figure, a common representational motif found in the Bennett Hills, closely parallels shield figures located throughout the Great Plains (Keyser 1975). The Great Basin rock art tradition is used here to describe the Bennett Hills rock art. Styles present are the Great Basin Representational style, the Pecked Abstract style, the Great Basin Scratched style, and the Carved Abstract style. The Great Basin Representational style (figure 1.5) occurs regularly in the Bennett Hills. It is commonly executed as anthropomorph, zoomorph, or shield figure. The Pecked Abstract style is also common in the Bennett Hills. This style includes the curvilinear variant (figure 1.6) dominated by round abstract motifs, and the rectilinear variant (figure 1.7) consisting of abstract geometric motifs. The Great Basin Scratched style is well represented in the Bennett Hills (figure 1.8). It is thought to be one of the later rock art styles (Heizer and Baumhoff 1962). This style is dominated by abstract geometric motifs. The Great Basin Carved Abstract style was recently added by Cannon and Ricks (1999) (figure 1.9). Although the name of the style implies that these petroglyphs were carved, it is more likely that they were deeply pecked using the same method as other Great Basin styles. These petroglyphs can be up to an inch deep. It is thought to be one of the older petroglyph styles (Cannon and Ricks 2007). This style is not common in the Bennett Hills. It was not encountered as part of this research but has been previously recorded at other sites in the Bennett Hills. 


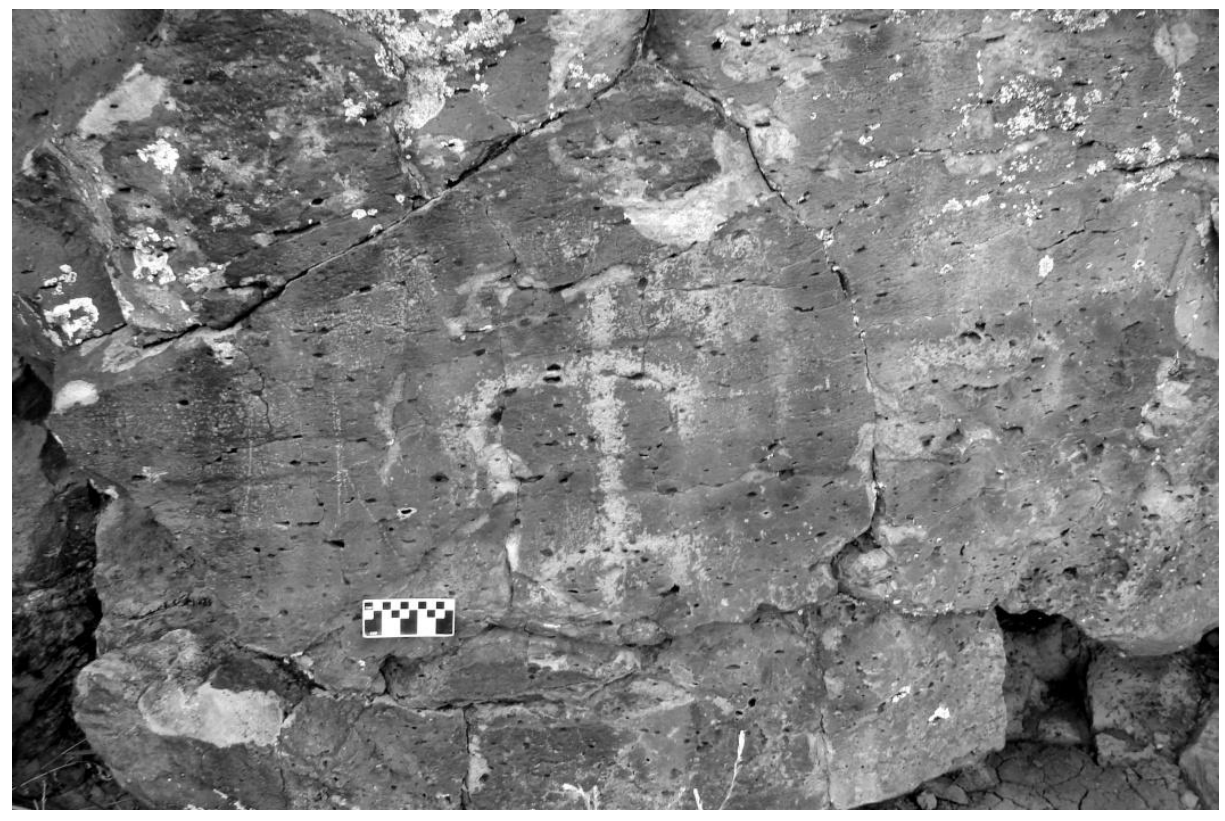

Figure 1.5. 10GG33, Great Basin Representational Style.

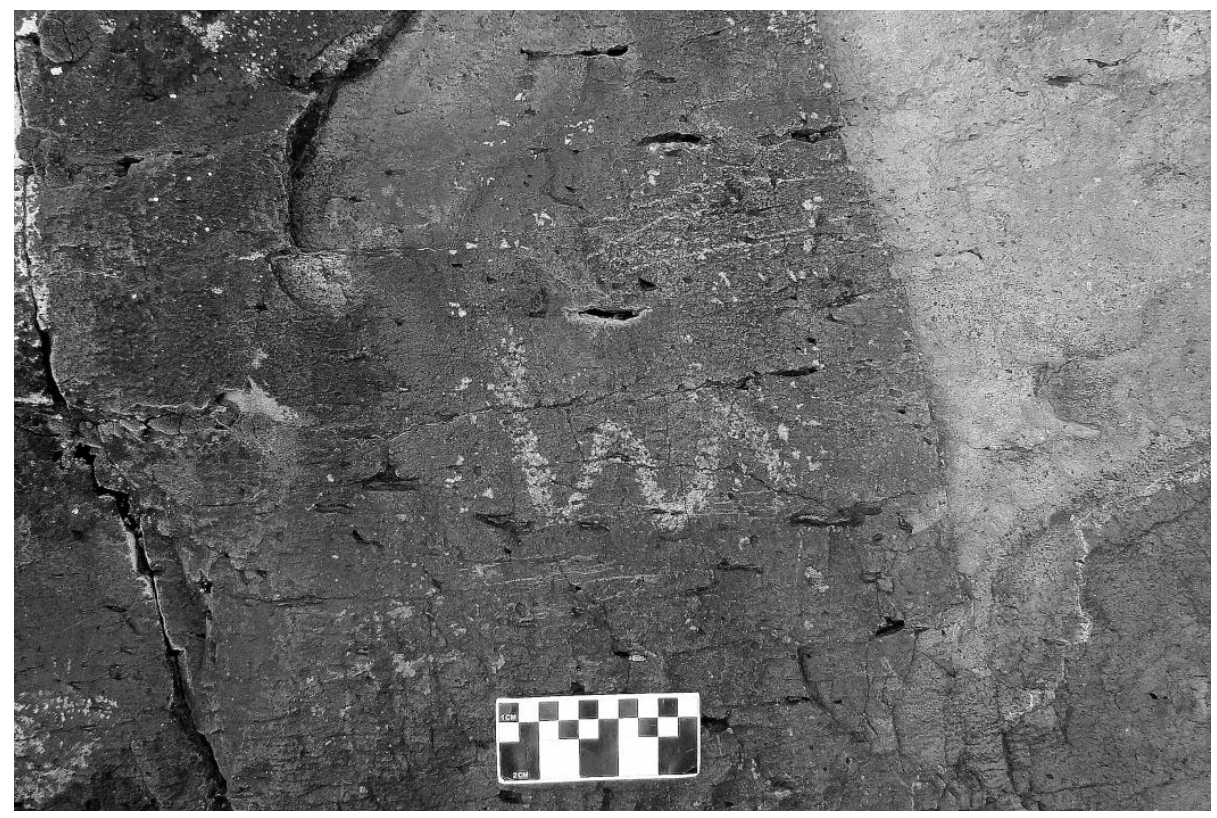

Figure 1.6. 10GG33, Great Basin Pecked Abstract Style, curvilinear variant. 


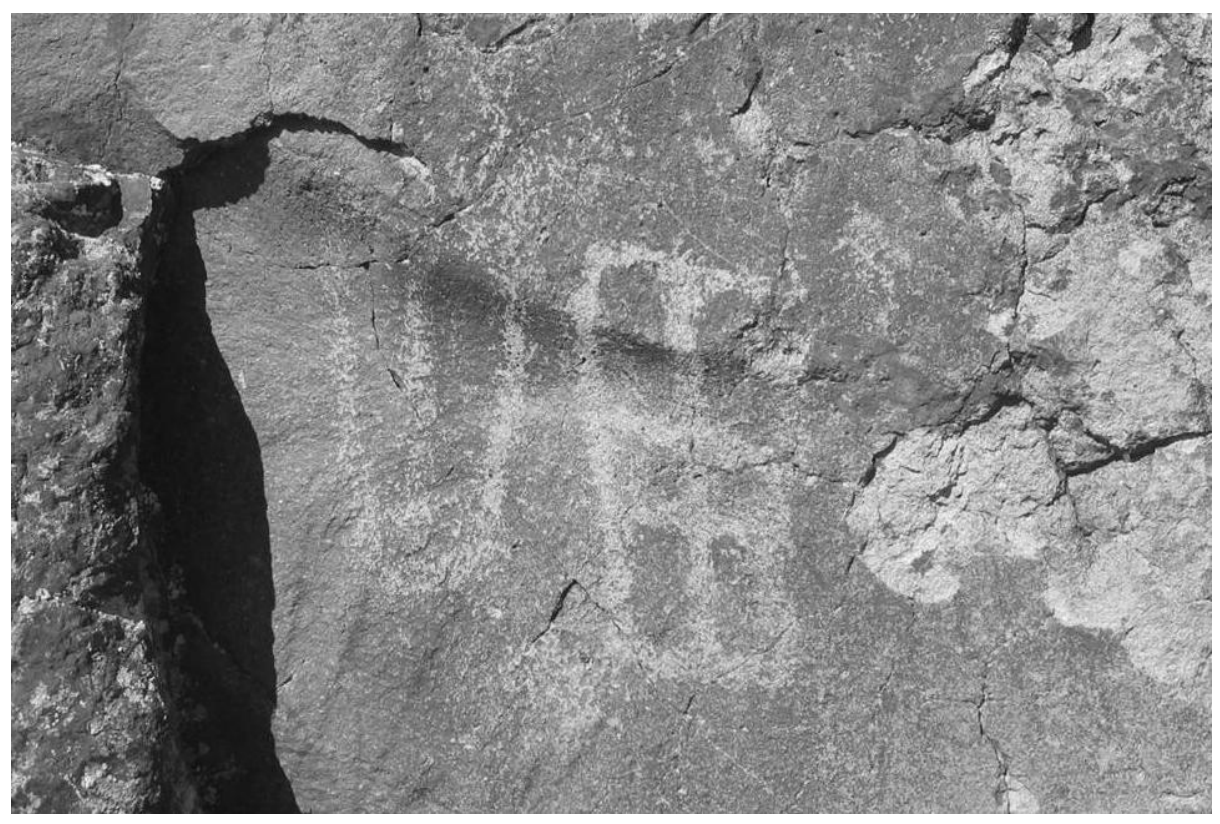

Figure 1.7. Great Basin Pecked Abstract style, rectilinear variant.

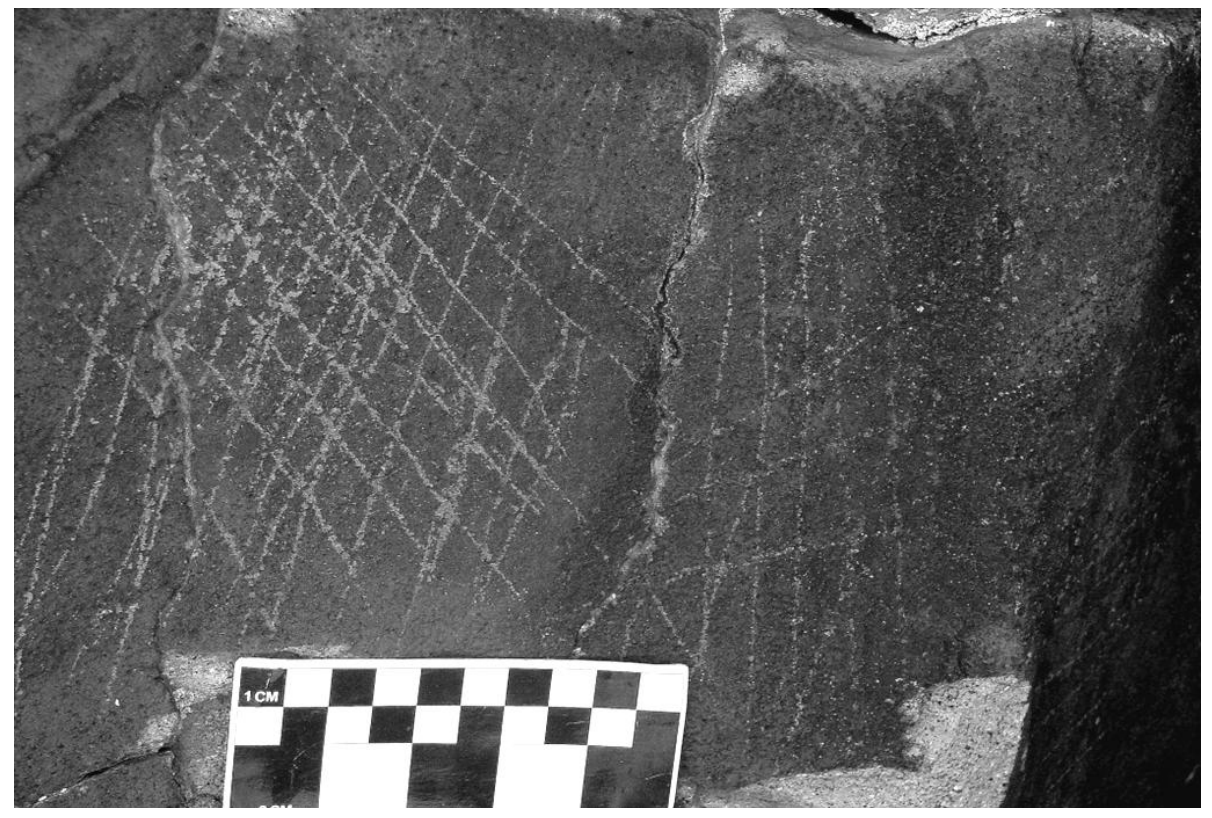

Figure 1.8. 10GG783, Great Basin Scratched Style. 


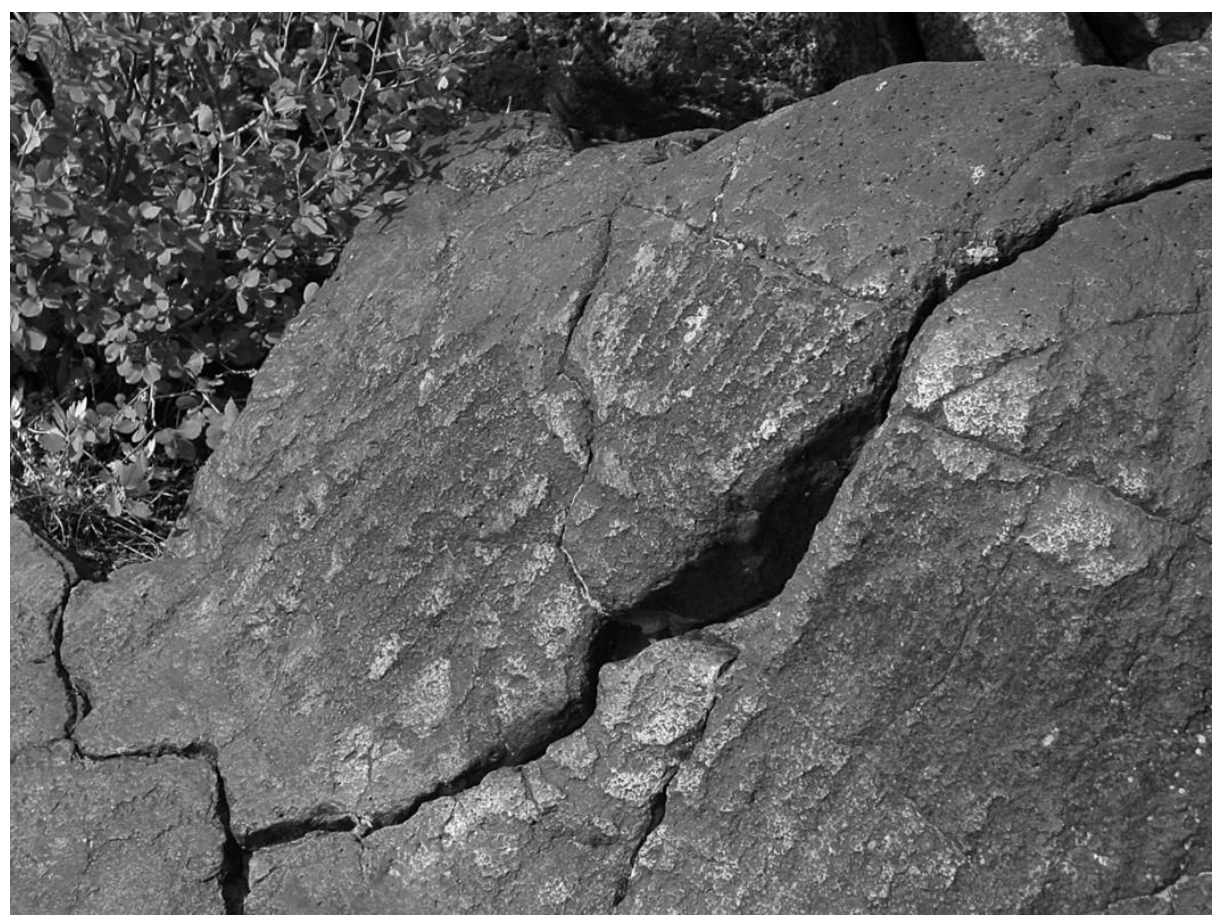

Figure 1.9. Tom's Spring, Great Basin Carved Abstract style (Merell and Dorn 2009).

There have been some relative chronological generalizations concerning the Great Basin rock art typology but the styles do not represent specific culture periods. This typology defines an assemblage of rock art styles having considerable chronological overlap spanning a long period of time (Whitley et al. 1984). The Great Basin rock art typology has been subject to criticism (Gebhard 1963; Hedges 1982; Schaafsma 1985, 1971; Dewdney 1979), but there has been no attempt to develop better style categories. The Great Basin rock art typology continues to be widely applied in modern rock art literature.

Most scholars accept that the technical and artistic skills of North American prehistoric hunter-gatherers did not evolve from simple to complex (Whitley 1998). One cannot assume that rock art styles and motifs that appear simple and rudimentary, the Great Basin Scratched Style for example, are older and attributable to less complex 
cultures. Furthermore, intricate and elaborate rock art styles and motifs are not necessarily the product of highly developed, complex cultures.

Archaeologists (Heizer and Baumhoff 1962; Plew 1996; Thomas 1979) argued that rock art in the Great Basin is produced in association with resource acquisition. Plew (1996) made this association during his investigation of three rock art sites in the South Central Owyhee Uplands. Plew recognized an association between these three rock art sites, modern game trails, water, and rock alignments representing big game corralling sites. A connection is also made between camas meadows, biscuit root fields, and petroglyph elements representing these vital resources. He suggests the petroglyph sites function as a practical marking of resource areas.

Thomas (1979) is of the same opinion as Heizer and Baumhoff (1962), holding that rock art sites have had spiritual importance related to success in hunting and gathering activities. Scratched rock art serves as "symbolic correlates in the dramatization of concepts relevant to a cultural system which coordinated plant and food gathering and cooperative hunting into a complementary spatial and temporal scheme" (Thomas 1983b: 352). She points to an association between water, game trails, hunting alignments representing big game corralling sites, and rock art sites. In her research, Thomas (1979) demonstrates how certain petroglyphs ritually mark ambush stations related to communal big-game hunting. Alternatively, the art may have been generated for other reasons. Petroglyphs may have been produced in association with ceremonial, spiritual, or shamanic activities. Although this study examines some basic variables, like food and water, rock art sites in the Great Basin are also considered in shamanic contexts. 
Furthermore it is possible that rock art was produced in association with multiple activities including hunting, gathering, and spiritual guidance. Schaafsma (1986) recognizes that "Both locational and graphic evidence exist to indicate that the rock art styles in the area functioned in some capacity in connection with hunting ritual and in other shamanic contexts". However, explanations regarding the meaning of petroglyphs in the Bennett Hills may be subject to oversimplification. According to Pavesic and Studebaker (1993:49), the rock art of southern Idaho "is obscured by its own abstractness and by the fact that it does not, commonly, rest in meaningful juxtaposition with other artifacts."

\section{Scratched Petroglyphs}

Heizer and Baumhoff (1962:232-234) briefly defined scratched petroglyphs in their synthesis and classification of Great Basin and eastern Californian rock art. They initially identified the style as a crude rock art form with straight lines, sun figures, and cross hatches. Geometric motifs are common; curvilinear motifs are rare (Ritter 1994). Scratched petroglyphs are unique in that they are manufactured using a single stroke with a sharp instrument to produce a shallow scratch, unlike pecking with a chisel and hammerstone. Since Heizer and Baumhoff's (1962) brief initial identification and classification some progress has been made in understanding scratched petroglyphs (Stoney 1994; Ritter 1994; Hedges 1989). Ritter's (1994) work concerning two scratched petroglyph sites in northern Nevada is the most relevant to this research. He collected data to test hypotheses concerning their function and interpretation. The formal attributes and contexts of the scratched petroglyphs in Nevada appear similar to those of the 
Bennett Hills. He found that scratched petroglyphs occur at large community centers near camps, trails, springs, and primary hunting and foraging locations. He also found that the neuropsychological model (Blackburn 1977), suggesting that some scratched petroglyphs were made by individuals in a trance state, is the best fit for the hypothesis he tested. $\mathrm{He}$ makes an association between shamans, the spiritual realm, and physical sustenance. Overall, most researchers agree that scratched petroglyphs take a wider variety of forms, occur in more numerous contexts, and are more extensively distributed than initially thought.

The Great Basin scratched style has been located throughout the Desert West (Ritter 1994). Scholars identified and analyzed scratched petroglyphs in the Columbia Plateau (Keyser and Taylor 2002; Taylor and Keyser 2003; Keyser et al. 2006; Leen 1988), the Great Plains (Keyser and Klassen 2001), and the Southwest (Christensen 1992; Simonis 1968). These regions contain scratched petroglyphs that are unique and distinct, although there are some similarities with Great Basin scratched style petroglyphs. Cultural exchange is evident in similarities between the rock art in these regions.

The Great Basin the scratched petroglyph motif assemblage is surprisingly homogenous despite the presence of numerous archaeologically prehistoric and protohistoric cultures within the Great Basin through time. However, there is some meaningful variability in content and context, perhaps representing separate styles in different regions (Ritter 1994). If scratched petroglyphs were distinguished in specific areas then styles could be assigned reflecting specific cultural traditions. Determining 
rock art styles can assist in reconstructing cultural boundaries, interaction, and isolation (Schaafsma 1985).

Scratched petroglyphs have been previously located in other areas throughout Idaho including Hells Canyon on the western boarder of Idaho (Leen 1988), Birch Creek Valley in southeast Idaho (Merrell 2002, 2003), Black Canyon Wilderness Study Area also in southeastern Idaho (Merrell 2000), the Middle Fork of the Salmon River in central Idaho (Merrell 2004), and the Bruneau River in south central Idaho (Murphy 1994). These are areas frequented by the same peoples who occupied the Bennett Hills during historic times (Shoshone, Paiute, and Bannock tribes). In these regions scratched petroglyphs are associated with pictographs and petroglyphs.

There are a few ideas concerning the interpretation of scratched petroglyphs in western North America that are not tested or discussed in detail because the ideas have not been sufficiently developed. Simonis (1986), Davis et al. (1965), and Stoney (1994) identified an association between scratched petroglyphs, trails, and trail markers in California and the Southwest. Many scholars have identified an association between motifs found in scratched petroglyphs and basketry (Fowler and Dawson 1986; Thomas 1983a; Whitley 1988; Jones 1986, Ritter 1994). Scratched petroglyphs have also been attributed to counting or tally marks (Davis et al. 1965). In Mendocino California there is also documentation of scratching rocks for controlling rain and for women wishing to conceive a child as part of a fertility enhancing ritual, rain being strongly associated with fertility (Clewlow 1978). Scratched petroglyphs may potentially represent varying ideas, intentions, and perceptions (Conkey and Hastorf 1990). 
Based on a synthesis of associations among scratched rock art, portable art, and other datable archaeological remains, Ritter (1994) concluded that scratched petroglyphs in the Desert West date within the last 1,000 to 1,500 years, although some scratched petroglyphs are likely older, dating to at least the Middle Archaic (5,500 - 3,500 B.P.) in parts of the Great Basin (Ritter 1994). Using lead-profile dating and varnish microlamination (VML) a scratched petroglyph from an extensive petroglyph site (Indian Writing Waterhole, 10GG30) in the Bennett Hills is dated between 100 and 350 B.P. (Merrell and Dorn 2009). Both of these dating methods are preliminary and still under review. Local historians recounted that Indian Writing Waterhole was a favorite camp site and rock art site into the 1920's (Bard 2000, 2005), suggesting rock art, and possibly scratched petroglyphs, were produced in the study area as late as the early $20^{\text {th }}$ century. In addition to cliff faces, scratched petroglyphs have also been identified on small portable stones (figure 1.10). The term for this phenomena has little consistency in the literature, but will be designated as scratched stones in this study. Some parallels between portable scratched stones and scratched rock art on non-portable rock surfaces have been hypothesized (Pilling 1957; Santini 1974; Pilles 1975; Moriarty 1982; Christensen 1992; Hedges 1989; Thomas 1983a). Scratched stones are commonly small enough to fit in the palm of a hand or smaller. They are either scratched using straight lines, a zigzag pattern, or a dotted line spaced at regular intervals (Klimowicz 1988). Seventy five percent of a sample of scratched stones from the Great Basin are made using the straight line technique (Klimowicz 1988), which is the only technique used to 
manufacture scratched petroglyphs (Stoney 1994). The scratches may be incised on one or multiple sides of the stone.

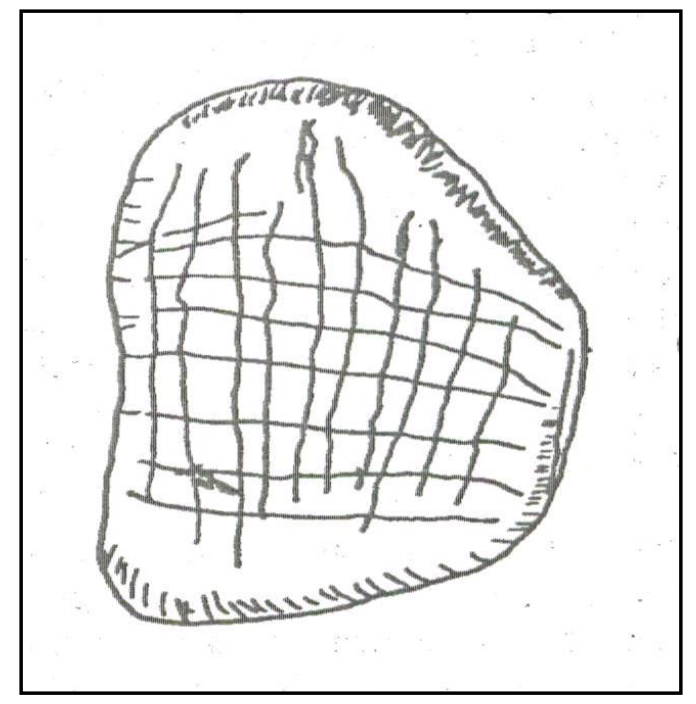

Figure 1.10. Scratched stone (Santini 1974).

Scratched stones are a widespread and long-standing archaeological phenomena (Thomas 1983a). They have been located throughout the Great Basin, in other regions of North America, and throughout the world. This broad distribution correlates with that of scratched petroglyphs. The earliest example from North America were recovered in North Carolina dating to 8,000 B.P. (Coe 1964; Schuster 1968). Examining parallels between scratched stones and scratched petroglyphs may be useful because portable stones can be recovered from datable archaeological deposits. It is far more difficult to obtain dates for scratched petroglyphs. If there are stylistic parallels between scratched petroglyphs and stones, then the stones may help build a chronology for scratched petroglyphs. It is also possible that if scratched petroglyphs and stones were found to be stylistically similar then one could assume that they share similar social functions (Pilling 1957). This may bolster our understanding of both scratched stones and 
petroglyphs. Stylistic similarities between scratched petroglyphs and stones are examined in more detail later in this study.

Overall, scratched petroglyphs have not been properly recorded or represented in rock art literature in comparison with other rock art related studies. Scratched rock art can often be very faint, thus less visible than other rock art styles. Scratched petroglyphs do not always penetrate the rock varnish of the host rock and can also accumulate varnish quickly (Christensen 1992). It is often overlooked in the field as a result of bias towards more impressive and elaborate rock art styles. In the past scratched rock art was mistaken for modern graffiti. Because scratched petroglyphs are often faint, less elaborate, and resemble graffiti they were often ignored or misunderstood and as a result have not been sufficiently recorded or researched.

The main goal of this research was to gain a better understanding of scratched petroglyphs in the Bennett Hills. The proposed study will add valuable data to the rich yet understudied concentration of rock art in the Bennett Hills and also contributes data to our limited understanding of scratched petroglyphs. It may raise and possibly answer questions that better known rock art research has not. 


\section{Chapter 2, Hypotheses and Methods}

This study draws from formal and contextual methods. The best rock art research employs multiple approaches including both formal and informed approaches (Whitley 2005). The main goal of this research was to gain a better understanding of scratched petroglyphs in the Bennett Hills. This study attempted to establish what scratched petroglyphs look like, how many there are within the study area, and where they are located. Formal qualities were also studied to test hypotheses concerning the relationship between scratched and pecked petroglyph styles and associations between scratched petroglyphs and other archaeological phenomena. Schaafsma (1985) is critical

of arbitrary and systematic recordation forms and techniques that are not relevant to anything in particular, carry no theoretical justification, and have no relevance to rock art problems. In this study, multiple lines of evidence informed by a broad set of methods are examined to understand specific attributes and functions of scratched petroglyphs in the Bennett Hills.

\section{Formal Methods}

Formal approaches use quantative, qualitative, and locational data to study rock art. These types of analyses employ an etic, or outside interpretation, and are often concerned with social functions of rock art rather than symbolic interpretation. Studies concerning classification of style and motif have dominated the history of rock art research. Formalism is significant in that it has led to the identification of rock art styles 
and traditions assigned to specific cultures and chronologies (Schaafsma 1985). Studies using formal rock art research help determine cultural boundaries, interaction, and isolation (Bettinger and Baumhoff 1982; Castleton and Madsen 1981; Curtis 1990; Keyser 1975; Lee and Hyder 1991; Monteleone 1998; Quinlan and Woody 2003). Recognizing patterns and structure in rock art can lead to identification of styles and traditions with specific cultural and chronological definitions. This is one of the aspects of style that make it valuable as an archaeological tool (Schaafsma 1985). Associating rock art with a specific cultural phase is difficult due to the limited temporal correlations between rock art and other datable archaeological materials. Rock art styles with temporal and cultural definitions do not require correlations with other archaeological phenomena.

Various formal attributes of scratched petroglyphs were collected and analyzed in this research contributing valuable qualitative and quantative data. Scratched petroglyphs were traced and photographed to collect detailed images. These images were used to create 17 motif categories that help quantify and qualify the scratched petroglyph motif assemblage in the Bennett Hills. Because these sites contain scratched and pecked petroglyphs both were counted at each site to quantify the proportion of scratched petroglyphs in comparison with pecked petroglyphs. To estimate the extent of scratched petroglyphs in the Bennett Hills a sample of ten petroglyph sites were tested to determine if scratched petroglyphs were present or not. This data is used to estimate the number of petroglyph sites where scratched rock art is present in the Bennett Hills. 


\section{Contextual Methods}

Contextual rock art studies are productive in associating rock art with other aspects of the archaeological record. Molyneaux (1977) distinguishes between "formalism" and "contextualism", two basic theoretical camps in rock art research. Formalism deals only with the formal qualities of rock art imagery. Formalism is the study of the physical form of rock art, independent of the archaeological context in which it may occur. Formalist studies are mainly concerned with style classification. Contextualism is the study of rock art emphasizing the cultural context and the physical environment in which the art occurs. Molyneaux (1977) argues that the history of rock art research has been dominated by formalist studies and calls for a balance in contextual interpretations.

Contextual rock art studies are significant in that they can be used to gain an understanding of the activities and social practices associated with rock art production and use (Bradley 1997). Studies concerning rock art patterning and distribution on landscapes have seen significant advancement (Chippendale and Nash 2004; Hambelton 2008; Cannon and Ricks 2007, 1986; Ricks 1995; Plew 1996). The spatial context in which rock art occurs has functional implications. The assumption that rock art is distributed on the landscape in a patterned way in relationship to environmental variables (plants, animals, water, elevation, geologic landforms) and other cultural remains suggests it is integrated within a variety of non-random activities (Schaafsma 1985). Contextual relationships among rock art motifs, panels, archaeological phenomena, and 
the environmental setting of the site location are important factors in interpreting rock art as well as identifying patterns of ritual, social, and political behavior (Schaafsma 1985).

This research examines a number of contextual associations between scratched petroglyphs and other archaeological and natural phenomena. At each site, elevation, distance to water, aspect, site type, and significant geological features are recorded to analyze broad associations between the landscape and scratched petroglyphs. Smaller scale contextual associations include aspect and inclination of the rock art panel, artifact and feature associations, and association with other petroglyphs on the panel and throughout the site.

\section{Fieldwork}

Two samples of ten rock art sites were drawn for this research for a total of 20 sites examined representing 32 percent of the 63 previously recorded rock art sites within the study area (figure 2.1). Data were collected from the second sample to estimate the number of sites in the Bennett Hills that contain scratched petroglyphs. Sample One was a non-random selection of 10 out of the 63 petroglyph sites where scratched petroglyphs have been previously identified and recorded. Within this sample specific contextual and formal data were collected. Data were also drawn from Sample One to test hypotheses concerning the relationship between scratched and pecked petroglyph styles and associations between scratched petroglyphs and other archaeological phenomena.

Fieldwork was conducted from 6/19/2010 to 6/28/2010 by Karla Hambelton, a graduate student at Portland State University, and assisted by Teacie Hambelton. A four wheel drive vehicle was used to navigate the rough and unimproved roads of the Bennett 
Hills. Most sites are located off-road and required a hike between a quarter to three miles round trip. To make the most efficient use of time and funds, a field camp was set up on Clover Creek, in a central location within the Bennett Hills. Regular contact was maintained with Lisa Cresswell (BLM archaeologist) while in the field to report progress and confirm safety and well being.

The study area encompasses lands primarily managed by the BLM Shoshone Field Office with limited private and state ownership. Because most of the lands within the study area are managed by the BLM, drawing exclusively from BLM site records does not exclude large parcels of land from the study. Fieldwork was conducted in accordance with BLM permit number ID-I-36784. Site records were obtained through the Idaho State Historic Preservation Office (ISHPO). Site data were also obtained from a database of petroglyph sites previously compiled for the Shoshone Field Office by California State University, Bakersfield (CSUB). This database contains information compiled from site forms for each rock art site. The quality and quantity of data greatly varies between each record due to inconsistencies throughout the last 50 years in recording practices and standards.

Data were collected from the second sample to estimate the number of sites in the Bennett Hills that contain scratched petroglyphs. The second sample (Sample One is discussed below) is a random sample of 10 sites drawn from the Bennett Hills rock art sample which had no previously recorded scratched petroglyphs. These sites were selected using a random number generator. The purpose of this sample was just to 


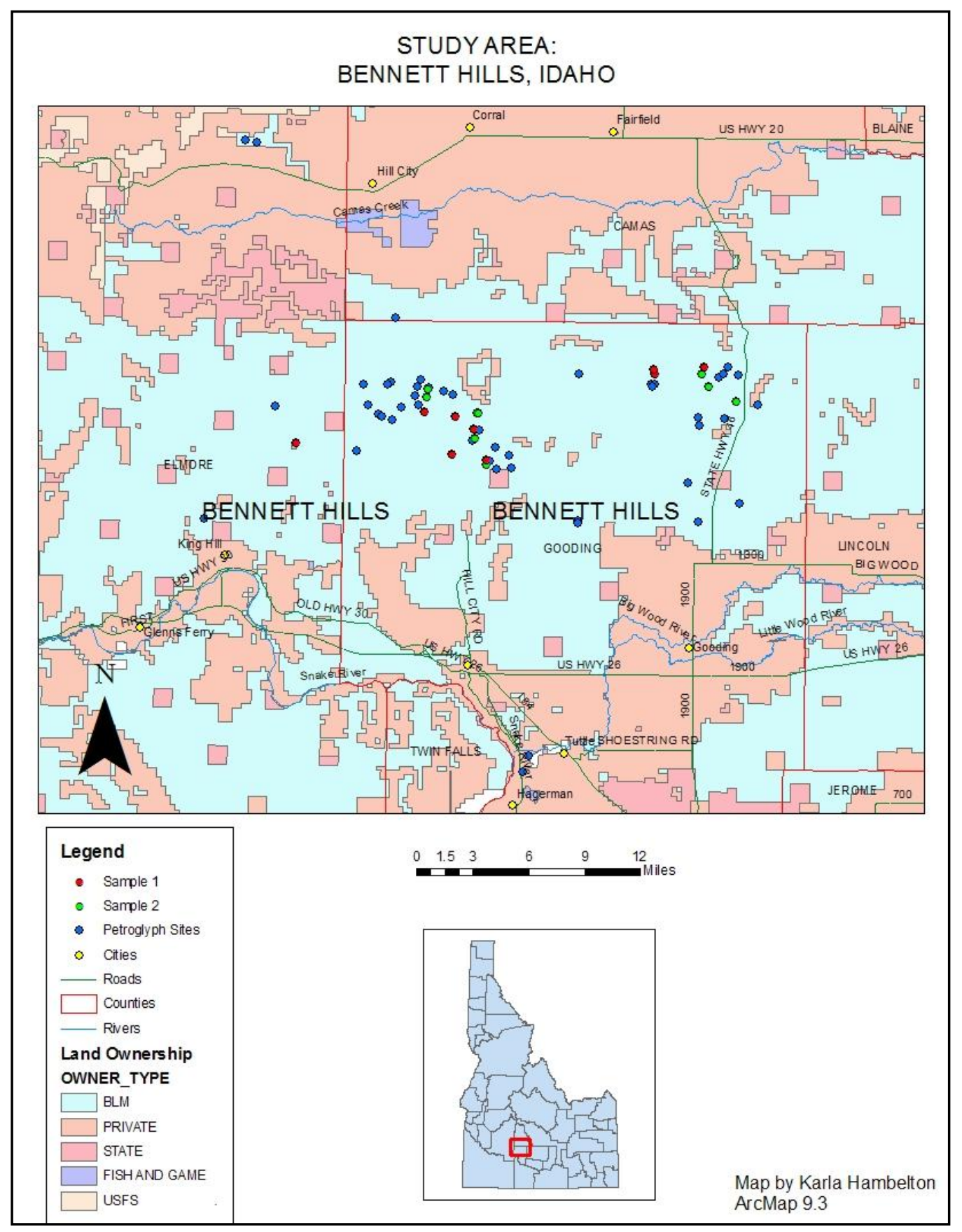

Figure 2.1. Study area, Sample One and Two.

record whether scratched petroglyphs were present or absent in order to estimate the overall frequency of scratched petroglyphs in the Bennett Hills. Because of inconsistencies in recording standards specific detail concerning the motif and style of 
petroglyphs were not recorded on some site forms. Rather, site forms simply indicate the presence of petroglyphs, but provide no further elaboration. There are also instances where details concerning petroglyphs are included, but scratched petroglyphs are ignored. This may be the result of people bypassing scratched petroglyphs for more interesting and elaborate rock art styles, mistaking them for graffiti, or overlooking them as they are at times faint and difficult to see. These inconsistencies make the petroglyph site forms an unreliable source for determining if scratched petroglyphs are present, and thus an inaccurate tool for estimating the number of petroglyph sites containing scratched petroglyphs in the Bennett Hills.

At each of the ten petroglyph site locations comprising the second sample the entire site was carefully examined. Some site forms contained detailed site data and maps concerning the location and description of artifacts and features. Other site records are very brief and vague. Each site was carefully examined to determine if the site record was an accurate representation of the current site condition. This prevented the bypassing of rock art, features, and artifacts that had not been previously located and recorded within the site boundary that would contribute to the research. As part of an agreement with the BLM those site records that were not accurate were updated and amended. If the site record was sufficient then a Cultural Resource Monitoring Form was completed also in agreement with the BLM. This form provides data concerning the overall site condition in response to wild animal, livestock, environmental, and human impacts. It provides important baseline data for preservation. 
After each site was carefully examined, the rock art within the site boundaries was surveyed specifically to identify scratched petroglyphs. Since the purpose of this sample is only to estimate the number of petroglyph sites where scratched rock art is present in the Bennett Hills, scratched rock art was neither recorded in detail nor counted. The second sample was only tested to determine if scratched petroglyphs are present or not.

Sample One was a non-random selection of 10 out of the 63 petroglyph sites where scratched petroglyphs have been previously identified and recorded. These sites were selected because they are known to contain scratched petroglyphs, but also selected for their accessibility. To meet time and budget constraints two weeks were allotted to fieldwork. Selecting sites that required minimal travel time helped meet those constraints. The bulk of the data for this thesis was collected in Sample One. At each of the ten petroglyph site locations comprising the first sample each scratched rock art panel was recorded using the "Scratched Petroglyph Survey Form" (Appendix B). This form streamlined the recordation process and ensured a uniform and organized data set in the field. The Scratched Petroglyph Survey Form was carefully designed before fieldwork began to collect specific contextual and formal data and to test hypotheses concerning the relationship between scratched and pecked petroglyph styles and associations between scratched petroglyphs and other archaeological phenomena.

At each scratched petroglyph the aspect or the direction the rock art was facing was measured using a hand held compass. Because volcanic rocks may distort compass readings the aspect was recorded roughly 10 meters from the rock. Many of the site locations were very rocky making it difficult to find an area free of rocks and close 
enough to the petroglyph to take an accurate aspect reading. Because of these potential sources for error aspect readings were recorded in eight general directions; north, northeast, east, southeast, south, southwest, west, and northwest. Recording aspect in these eight general directions instead of to the nearest degree was less precise, but reduced the margin for error and made it easier to recognize patterning in aspect.

Inclination was recorded at each scratched petroglyph. Inclination of the rock surface on which the petroglyph occurred was measured using a hand held compass. Similar precautions were taken for error associated with using a compass near rock. Inclination was recorded to the nearest degree, but will be analyzed in ranges of degree (0-44 degrees and 45-90 degrees) to recognize patterning.

Artifacts and features within a ten meter radius of the scratched petroglyph panel were identified and recorded. Standard pedestrian survey methods were employed to examine the ground surface. Both cultural artifacts and features and relevant natural features were recorded. Relevant natural features included caves, rockshelters, and overhangs.

Vandalism and natural disturbances including graffiti, natural chipping and spalling, and lichen growth were identified and recorded at each scratched petroglyph panel. This data will be used to assess the general condition of the rock art and to discuss future management concerns.

At sites in the first sample each scratched rock art motif was tallied. A separate count was kept for pecked and petroglyphs. These counts are calculated to establish the percentage of scratched petroglyphs and the percentage of pecked petroglyphs at each 
site. These are used in conjunction with the data from Sample Two to help establish a quantitative estimate of scratched petroglyphs within the study area.

Digital photography was used to visually record scratched rock art. The number of photos taken at each panel depended on the size and complexity of the panel. At each rock art panel with scratched petroglyphs a wide shot of the entire panel was taken to record the general location and context. In addition to the wide shot a close up of each separate scratched motif was taken to provide a detailed record of the motif. A scale was included in each photo. Direct sun on the panel resulted in washed out and unclear photos. Most panels had to be completely shaded to capture a clear image. A detailed photo log was kept to record the date, site number, photo number, direction, and content. It was difficult to clearly photograph some scratched rock art. The scratches are often faint and difficult to see. The tracing method provided an excellent primary record and the photos served as a backup record. At each petroglyph panel sheets of clear plastic were carefully placed over the rock art and secured with a small piece of removable sticky tack. Using a black sharpie pen the petroglyph panel was traced onto the clear plastic sheet. Tracing the rock art created an accurate and clear image of the rock art that was often difficult to capture in a photograph. Great care was taken to assure the sticky tack was fully removed from the rocks and that no sticky tack was directly placed on the petroglyphs. Care was also taken to assure that the plastic sheets were fully intact and completely covering the rock art so that there was no chance of pen bleeding through or slipping onto the rock art below. All precautions were taking to assure that this method 
had zero impact on the rock art. These tracings were reduced using a photo copier to fit on standard sized paper, and are listed in Appendix A.

Site forms from each site were studied to collect and analyze additional site data. Site description, environmental, and geographic data were compiled and described.

Initially the ten sites and the associated petroglyphs in the first sample were to be recorded and mapped using a hand held GPS and GIS software. Unfortunately, there were some issues with the Garmin GPS unit that would have been employed to assist in navigation, mapping petroglyphs, and designing site maps. Accuracy for this particular unit was only up to 10 meters with excellent satellite coverage. Because the petroglyph panels were often lumped in a small area this degree of precision was not sufficient. Furthermore, it was very difficult to obtain enough satellites for the unit to work properly despite clear and open skies. Detailed mapping of the petroglyph sites was included in the original thesis proposal, but was omitted due to these technical difficulties. United States Geological Survey (USGS) 7.5 series quadrangles of the study area provided general mapping and navigation data.

\section{Hypothesis Testing}

\section{Associations between Scratched and Pecked Petroglyphs}

There are various hypotheses that deal with the interaction between scratched petroglyphs and pecked petroglyph styles. Many of these hypotheses suggest that scratched petroglyphs are later than other Great Basin pecked petroglyph styles. Scratched petroglyphs are often located in association with pecked petroglyphs and have been identified superimposed over one another. Establishing the temporal order of 
scratched and pecked petroglyphs would provide important data concerning the relative dates of petroglyph styles in the study area. This data would also help inform what the intention of association or superimposition was between these two petroglyph styles.

To determine the temporal order of scratched and pecked petroglyph styles a Munsell rock color chart was used to measure relative accumulation of varnish to determine if scratched petroglyphs are contemporaneous, earlier, or later than associated pecked or abraded petroglyphs. During fieldwork a number of issues arose with this method. Applying the Munsell rock color chart to measure relative accumulation of varnish has significant room for error. As a result, this data was omitted from the final results. Sources for error are discussed in Appendix C.

Another method to recognize if scratched petroglyphs are earlier and superimposed over pecked and abraded petroglyphs is to identify if scratches are visible where the motifs are superimposed. If pecked petroglyphs were superimposed over scratched petroglyphs then the scratches would be destroyed and not be visible. Pecking covers the entire surface and fully penetrates the rock varnish. If a pecked motif was superimposed over a scratched petroglyph then it would completely obliterate the scratched motif where they overlap. This method can establish which motif was superimposed over the other with more accuracy than the relative repatination method.

Determining superimposition of the two techniques is difficult and somewhat subjective (Ritter 1994). Busby et al. (1978) are critical of this method. In their replicative study of petroglyph manufacture they found that when a scratched petroglyph is superimposed over a deeply pecked petroglyph it was not possible to determine which 
petroglyph was superimposed over the other. They also found that when a lightly pecked petroglyph was superimposed over a scratched petroglyph it was also not possible to determine which petroglyph was superimposed over the other. Other scholars trust that this method is accurate. With some experience and careful examination it should be clear which petroglyph is superimposed over the other (James Keyser, personal communication 2011). This method is not free of error but is superior to the Munsell method.

There are various hypotheses concerning the intention of association between scratched and pecked petroglyphs. Scratched petroglyphs occur in independent and isolated contexts but they are also often associated with other pecked petroglyph styles. First, data was collected to identify how many scratched petroglyphs are associated with pecked petroglyph styles and how many occur in isolated contexts. At each scratched rock art panel in Sample One the panel was examined for abraded and or pecked petroglyphs. If scratched rock art and abraded and or pecked petroglyphs occurred on the same panel then the scratched rock art was designated as associated (figure 2.2). If scratched rock art was the only type of rock art to occur on the panel then it was designated as not associated (figure 2.3). 


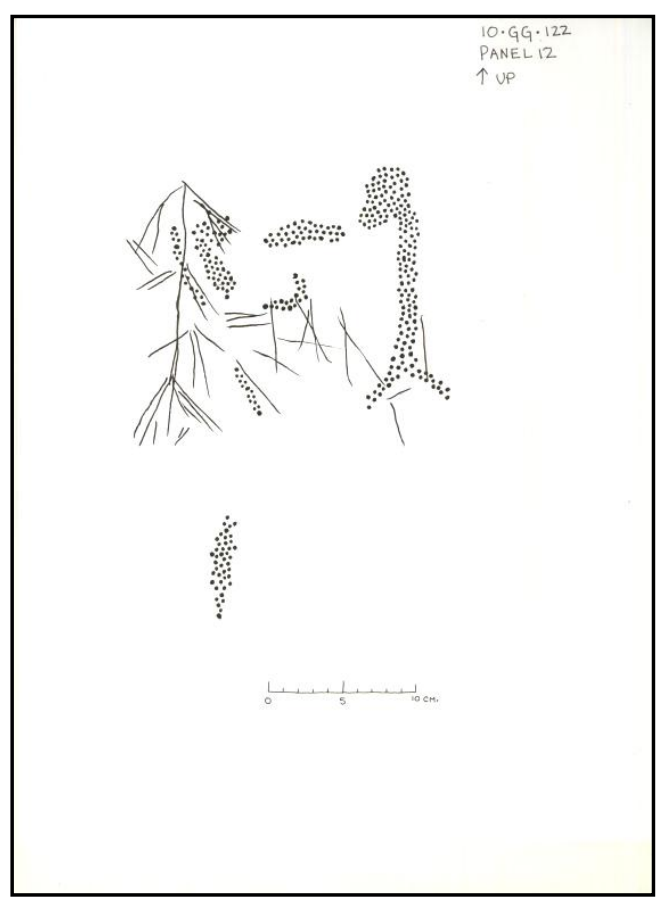

Figure 2.2. 10GG122, associated scratched and abraded petroglyphs.

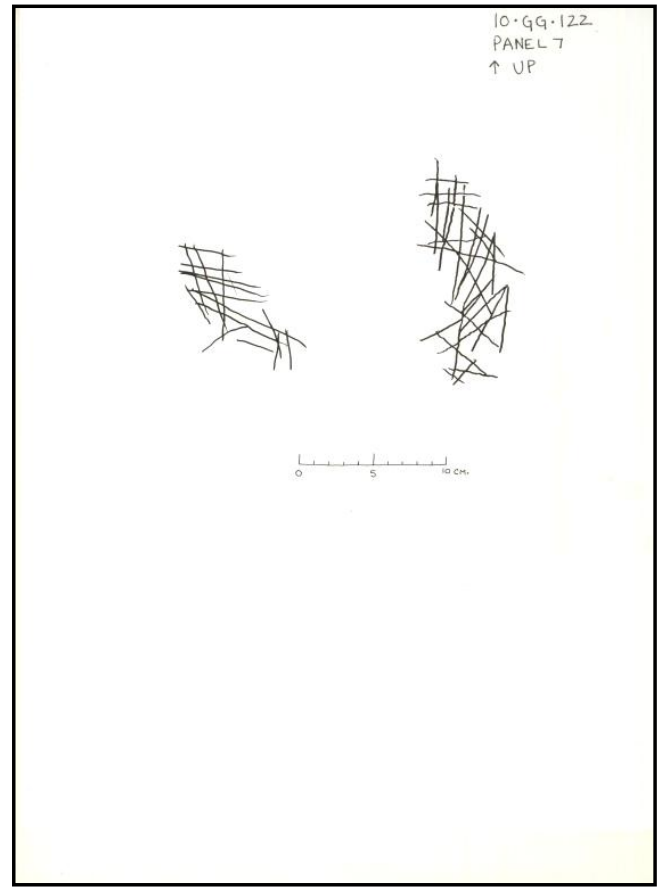

Figure 2.3. 10GG122, not associated scratched petroglyph. 
Data was also collected to identify if scratched petroglyphs are associated with specific pecked petroglyph styles. At each rock art panel where scratched petroglyphs were associated with pecked petroglyphs the associated pecked petroglyph was identified and recorded using the styles defined in the Great Basin rock art tradition.

Data was collected to test three hypotheses concerning the intention of association between scratched and pecked petroglyphs. Researchers have identified that scratched petroglyphs serve to obliterate earlier pecked petroglyphs, enhance earlier pecked petroglyphs, and serve as a sketch that would be pecked later. Specific data was collected to test these hypotheses and gain a better understanding of why scratched and pecked petroglyphs are associated.

The first hypothesis suggest superimposition of scratched petroglyphs over earlier pecked petroglyphs serves to obliterate earlier rock art and any power or significance it may possess Heizer and Baumhoff (1962) and Bettinger and Baumhoff (1982). This hypothesis is based on the idea that scratched petroglyphs in the Great Basin are the result of Numic speakers expanding north into the Great Basin who superimposed scratched petroglyphs over earlier petroglyph styles manufactured by pre-Numic inhabitants of the Great Basin. Specific data was not collected to test the Numic expansion hypothesis. The goal was to identify if scratched petroglyphs are superimposed over pecked petroglyphs for the purpose of obliteration. To test this hypothesis each rock art panel where scratched rock art was identified was examined to determine if scratched rock art was superimposed over the abraded or pecked rock art. Next, the percentage of superimposition was recorded. Percentage of superimposition was split in four categories; 
no superimposition, greater than 50 percent superimposition, less than 50 percent superimposition, and 100 percent superimposition. To ensure that these categories were adhered to consistently, diagrams representing the four categories were displayed on the Scratched Petroglyph Survey Form (Appendix B). These diagrams visually displayed the four categories of superimposition. Each time superimposition was recorded these diagrams were consulted to assign an accurate and consistent percentage category. This hypothesis suggests that scratched petroglyphs are later and superimposed over earlier pecked petroglyph styles. Data collected to determine the temporal order of scratched and pecked petroglyphs is also applied to help test this hypothesis.

The second hypothesis recognizes that scratched petroglyphs are often added to pecked or abraded petroglyphs as an embellishment. Its possible that these scratches were added after pecked or abraded petroglyphs were manufactured to alter the original purpose of the design either in a positive or negative manner (Hedges 1973). To identify this pattern each scratched petroglyph was examined to indicate whether the scratches are part of an abraded or pecked motif or a self contained scratched petroglyph, occurring independently. If the scratched rock art was associated then a brief description of the association was written concentrating on characteristic that either support or diverge from the hypothesis. This hypothesis suggests that scratched petroglyphs are later and superimposed over earlier pecked petroglyph styles. Data collected to determine the temporal order of scratched and pecked petroglyphs is applied to help test this hypothesis.

The third hypothesis posits that Scratched petroglyphs are a sketch or pre-form to plan a design that would be pecked or abraded later (Turner 1971; Pilles 1975). This 
phenomena is apparent when the design is not completed or the artist strays for the original scratched outline. This was identified in the Little Colorado drainage (Pilles 1975) and the Glen Canyon region in the Southwest (Turner 1971). Most common were geometric scratched pre-forms, but zoomorphic figures were also laid out using scratches. To test this hypothesis it is determined whether scratched petroglyphs are integrated into a pecked or abraded motif or if they are self contained scratched petroglyphs, occurring independently of any other petroglyphs. If the scratched rock art was associated then a brief description of the association was written concentrating on characteristics that either support or diverge from the hypothesis. This hypothesis suggests that pecked petroglyphs are later and superimposed over earlier scratched petroglyph styles. Data collected to determine the temporal order of scratched and pecked petroglyphs is also applied to help test this hypothesis.

\section{Scratched Stones}

This thesis also examines hypotheses suggesting associations between scratched rock art and other archaeological phenomena. The first hypothesis suggests portable scratched stones and scratched rock art on non-portable rock surfaces represent the same activity (Pilling 1957; Santini 1974; Pilles 1975; Moriorty 1982; Christensen 1992). If scratched petroglyphs and stones were found to be stylistically similar then one could argue they share similar social or ideological functions (Pilling 1957). This may bolster our understanding of both scratched stones and petroglyphs. Data were collected in the Bennett Hills to determine if scratched petroglyphs in that area are comparable to scratched stones in the Great Basin. 
Scratched petroglyphs in the Bennett Hills were compared to three assemblages of scratched stones in the Great Basin. The first is a small collection of 14 incised stones from southwestern Idaho (Plew 1976; Huntley and Nance 1980; Arkush 2011). Although the collection is small, it is significant in being adjacent to the Bennett Hills. Parallel lines, cross-hatches, and plant-like motifs are represented in this collection of stones and are the basis for comparison with Bennett Hills scratched petroglyphs.

The second collection from southern Nevada is comprised of 767 scratched stones analyzed by Santini (1974). Santini has quantified and categorized popular design elements within this collection. These design elements were the basis for comparison with Bennett Hills scratched petroglyphs.

The third collection is comprised of 428 incised stones from Gatecliff Rockshelter in Nevada analyzed by Thomas (1983a). Thomas (1983a) quantified and categorized a random sample of 165 incised stones using five elements combined into 48 motif elements. These motif elements are the basis for comparison with the Bennett Hills scratched petroglyphs.

Digital photos and tracings were taken at each scratched petroglyph in the Bennett Hills. Each scratched petroglyph motif was quantified using the categories laid out in each of the four scratched stone assemblages. Three separate comparisons were used to determine if there are substantial similarities between the stylistic attributes of scratched petroglyphs in Bennett Hills and a sample of scratched stones from the Great Basin. 


\section{Quartz}

The last hypothesis postulates an association between scratched rock art and quartz crystals. There is limited evidence that suggests scratched petroglyphs were manufactured with quartz artifacts. Quartz artifacts have been located in close proximity to scratched petroglyphs either on the ground surface (Murphy 1994) or wedged into cracks in the rock (Whitley et al. 1999). Some scholars believe scratched petroglyphs were manufactured using quartz because of the religious properties associated with both quartz and scratched petroglyphs (Merrell and Dorn 2009; Murphy 1994; Whitley 1994; Whitley et al. 1999). Two separate methods were implemented to test this hypothesis. All Bennett Hills rock art site records within the study area were reviewed to look for quartz artifacts that could possibly be associated with the manufacture of scratched petroglyphs. Second, at panels with scratched rock art, the ground surface was examined to locate quartz artifacts. A 10 meter radius around the scratched rock art panel was surveyed using standard pedestrian survey methods. 


\section{Chapter 3, Results}

Two samples of ten rock art sites were drawn for this research for a total of 20 sites examined (figure 2.1). This sample represents 32 percent of the 63 previously recorded rock art sites within the study area.

\section{Sample One}

Sample One was a non-random selection of 10 out of the 63 petroglyph sites where scratched petroglyphs have been previously identified and recorded. The bulk of the data for this thesis was collected as part of this sample. Data were collected in Sample One to define the extent, characteristics, and contexts of scratched petroglyphs in the Bennett Hills and to test hypotheses concerning the relationship between scratched and pecked petroglyph styles and associations between scratched petroglyphs and other archaeological phenomena.

\section{Sample Two}

Sample Two was used to estimate the number of sites containing scratched petroglyphs in the Bennett Hills. Ten sites were randomly selected from a sample of 63 petroglyph sites representing a 16 percent sample: 10GG101, 10GG103, 10GG137, 10GG284, 10GG478, 10GG566, 10GG666, 10GG735, 10GG736, and 10GG738. These sites were surveyed for the presence or absence of scratched petroglyphs. Scratched petroglyphs were located at all 10 sites in Sample Two. These results support the author's 
impression that scratched petroglyphs are severely under reported within the Bennett Hills.

\section{Formal Attributes}

In Sample One various formal attributes of scratched petroglyphs were collected and analyzed, contributing valuable qualitative and quantative data. Scratched petroglyphs were traced and photographed to collect detailed images. These images were used to create 17 motif categories that help quantify and qualify the scratched petroglyph motif assemblage in the Bennett Hills. Table 3.1 provides descriptions of each motif and a corresponding figure following the table. Table 3.2 displays the number and percentage of motifs in each category. Motif five (random lines), are scratched petroglyphs that do not appear to have any repeated patterns, composition, or association. This category was not quantified, due to the difficulty in determining how many motifs were represented. For example, it would be difficult to determine if a group of five random lines on a panel would be counted as five separate random line motifs or a single motif made up of random lines. Random lines were recorded as present or not present at each panel but they were not included in the total motif count in table 3.2. Random lines were located at 42 of the 69 scratched petroglyph panels (61 percent). A tally was counted at each panel for the other 16 categories. 
Table 3.1. Description of Scratched Motif and Figure Reference.

\begin{tabular}{|c|c|c|}
\hline $\begin{array}{c}\text { Motif } \\
\text { No. }\end{array}$ & Description & $\begin{array}{c}\text { Figure } \\
\text { No. }\end{array}$ \\
\hline 1 & $\begin{array}{l}\text { Motif } 1 \text { is a crosshatch, two or more vertical lines bisected } \\
\text { by two or more horizontal lines. These lines do not have to } \\
\text { be exactly perpendicular. }\end{array}$ & $\begin{array}{l}\text { Figure } \\
3.1\end{array}$ \\
\hline 2 & $\begin{array}{l}\text { Motif } 2 \text { is a crosshatch with two or more additional lines } \\
\text { bisecting at a } 45^{\circ} \text { angle. }\end{array}$ & $\begin{array}{l}\text { Figure } \\
3.2\end{array}$ \\
\hline 3 & $\begin{array}{l}\text { Motif } 3 \text { is parallel lines, two or more straight lines running } \\
\text { generally parallel to one another and the same length. }\end{array}$ & \begin{tabular}{|l} 
Figure \\
3.3 \\
\end{tabular} \\
\hline 4 & $\begin{array}{l}\text { Motif } 4 \text { is striations, a set of semi-parallel straight lines } \\
\text { closely set near one another that fill space. }\end{array}$ & $\begin{array}{l}\text { Figure } \\
3.4\end{array}$ \\
\hline 5 & $\begin{array}{l}\text { Motif } 5 \text { is random lines, lines with no repeated patterns, } \\
\text { composition, or association. }\end{array}$ & $\begin{array}{l}\text { Figure } \\
3.5\end{array}$ \\
\hline 6 & $\begin{array}{l}\text { Motif } 6 \text { is a cross, one horizontal line bisecting one vertical } \\
\text { line between a } 45^{\circ} \text { to } 90^{\circ} \text { angle. }\end{array}$ & $\begin{array}{l}\text { Figure } \\
3.6\end{array}$ \\
\hline 7 & $\begin{array}{l}\text { Motif } 7 \text { is a star, three or more straight lines that bisect one } \\
\text { another at a common center point. }\end{array}$ & $\begin{array}{l}\text { Figure } \\
3.7\end{array}$ \\
\hline 8 & Motif 8 is a "V" shaped line. & $\begin{array}{l}\text { Figure } \\
3.8\end{array}$ \\
\hline 9 & $\begin{array}{l}\text { Motif } 9 \text { is an arrow, a single straight line with two } 45^{\circ} \text { lines } \\
\text { extending off each side of one end. }\end{array}$ & \begin{tabular}{|l|l} 
Figure \\
3.9 \\
\end{tabular} \\
\hline 10 & Motif 10 is a human figure. & \begin{tabular}{|l} 
Figure \\
3.10
\end{tabular} \\
\hline 11 & $\begin{array}{l}\text { Motif } 11 \text { is a plant-like motif, a straight line with many } \\
\text { straight lines extending off both sides of the line at roughly } \\
\text { a } 45^{\circ} \text { angle. }\end{array}$ & $\begin{array}{l}\text { Figure } \\
3.11\end{array}$ \\
\hline 12 & Motif 12 is a crosshatch within two parallel lines. & \begin{tabular}{|l} 
Figure \\
3.12 \\
\end{tabular} \\
\hline 13 & $\begin{array}{l}\text { Motif } 13 \text { is a half plant-like motif. A straight line with many } \\
\text { straight lines extending on one side of the line at roughly a } \\
45^{\circ} \text { angle. }\end{array}$ & $\begin{array}{l}\text { Figure } \\
3.13\end{array}$ \\
\hline 14 & $\begin{array}{l}\text { Motif } 14 \text { is a ladder, two straight parallel lines with } \\
\text { perpendicular parallel lines running through the middle. }\end{array}$ & \begin{tabular}{|l} 
Figure \\
3.14
\end{tabular} \\
\hline 15 & Motif 15 is a circle. & \begin{tabular}{|l} 
Figure \\
3.15
\end{tabular} \\
\hline 16 & Motif 16 is a circle with parallel lines inside. & $\begin{array}{l}\text { Figure } \\
3.15\end{array}$ \\
\hline 17 & Motif 17 is a concentric circle, a circle within a circle. & \begin{tabular}{|l} 
Figure \\
3.16 \\
\end{tabular} \\
\hline
\end{tabular}




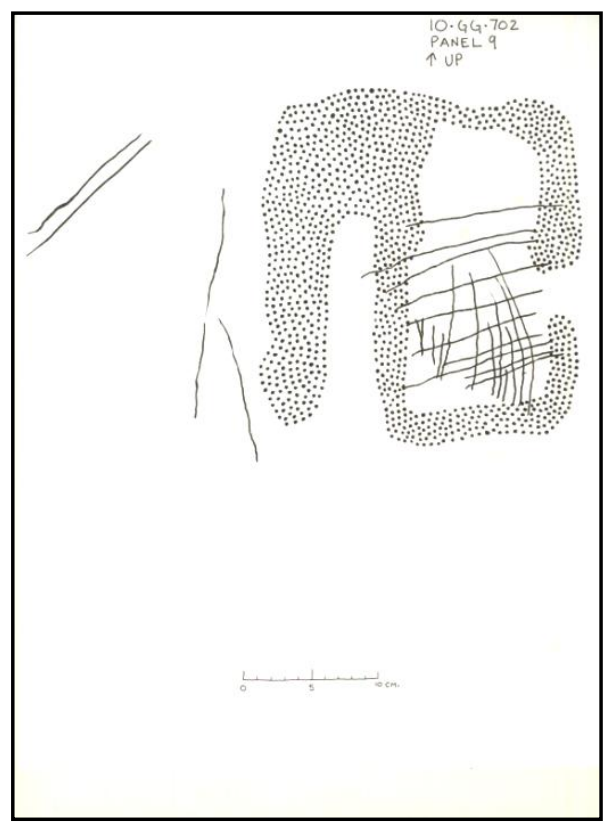

Figure 3.1. motif 1, 10GG702, panel 9.

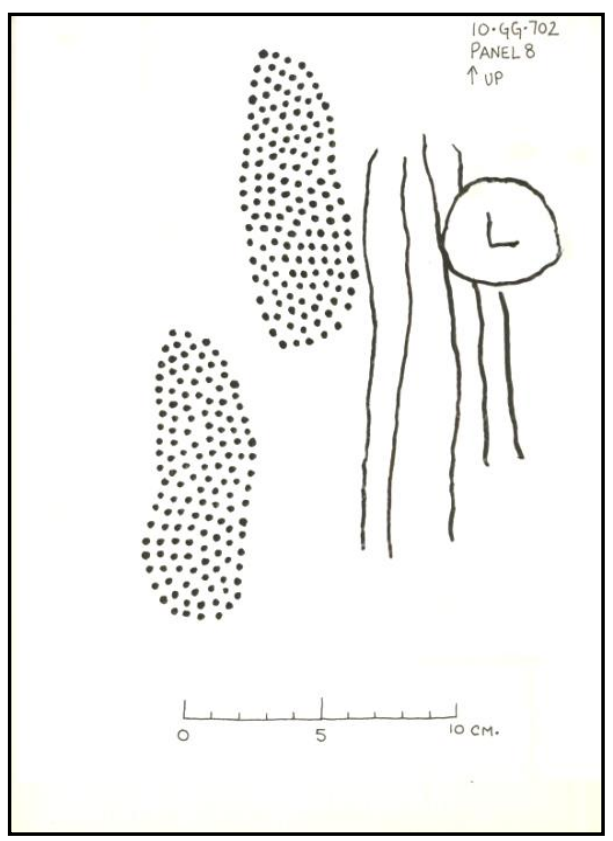

Figure 3.3. motif 3, 10GG702, panel 8 .

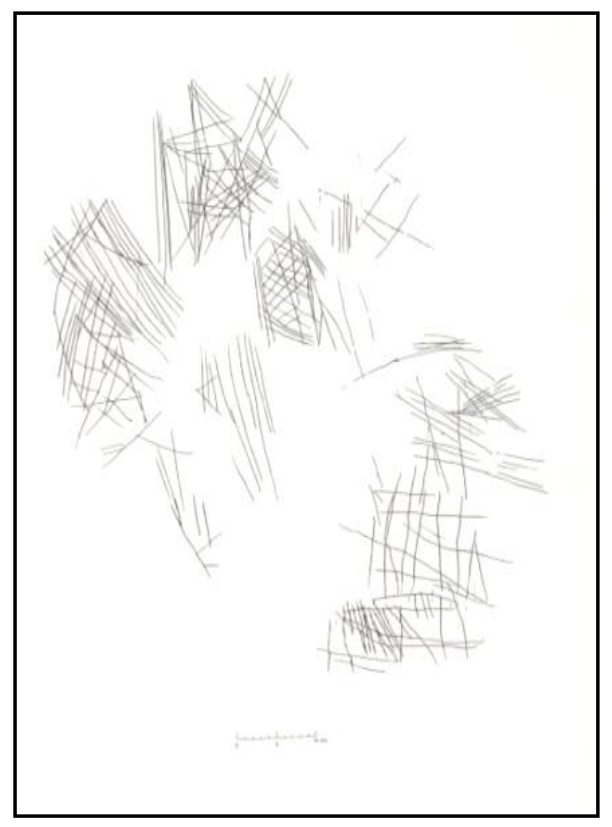

Figure 3.2. motif 2, 10GG122, panel 2.

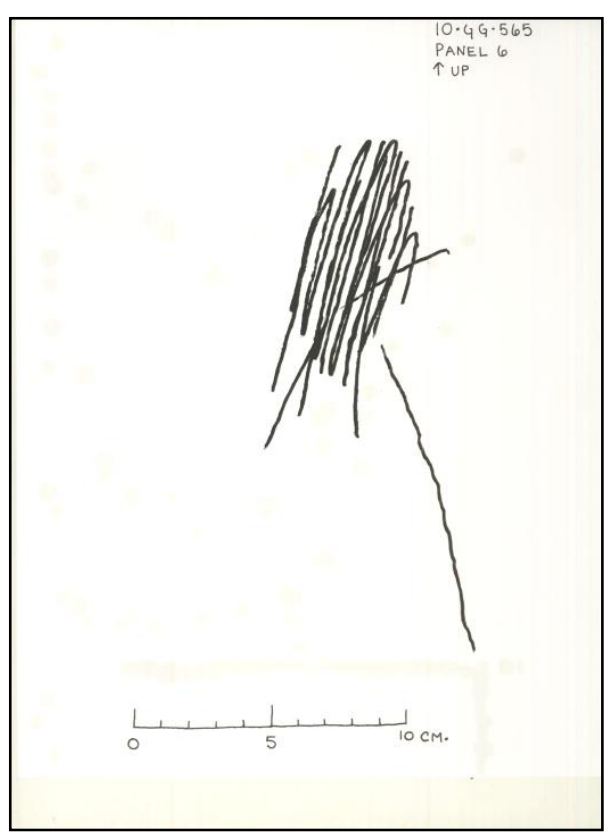

Figure 3.4. motif 4, 10GG565, panel 6. 


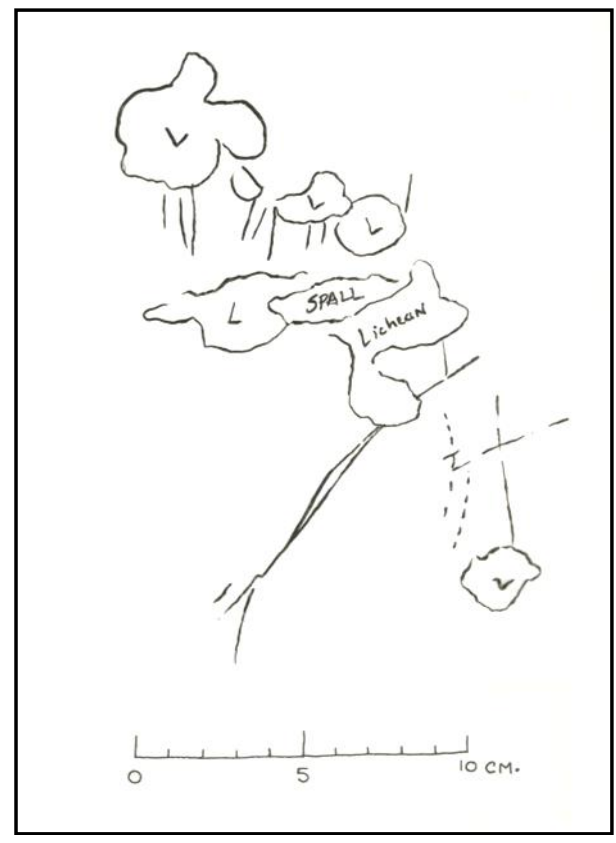

Figure 3.5. motif 5, 10GG33, panel 4.

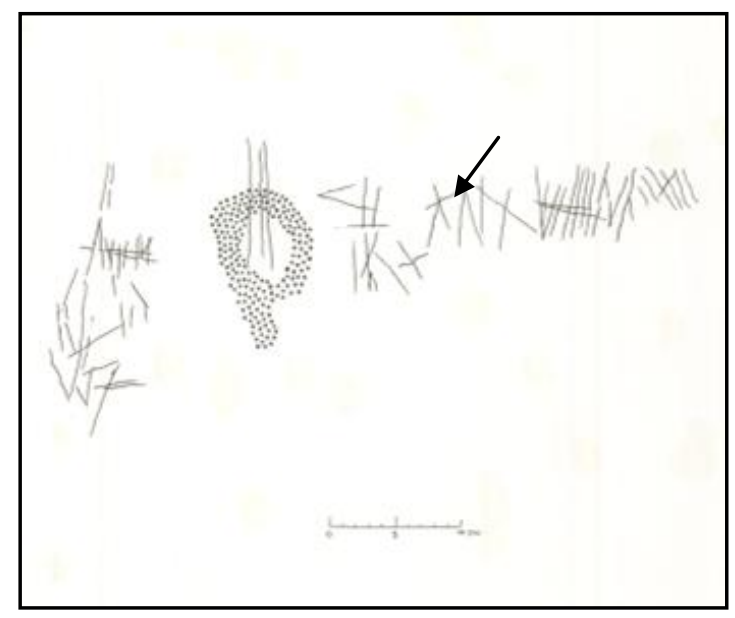

Figure 3.7. motif 7, 10GG33, panel 9.2.

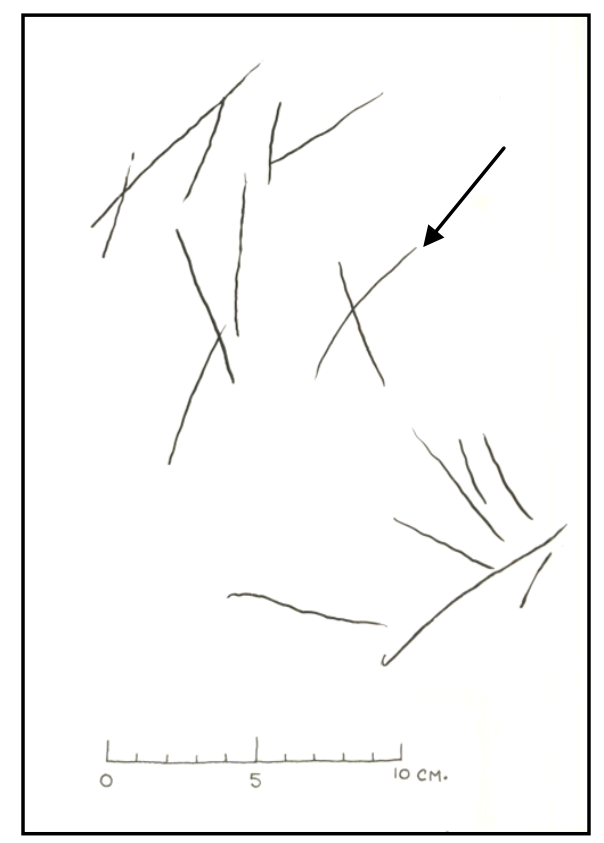

Figure 3.6. motif 6, 10GG33, panel 9.4.

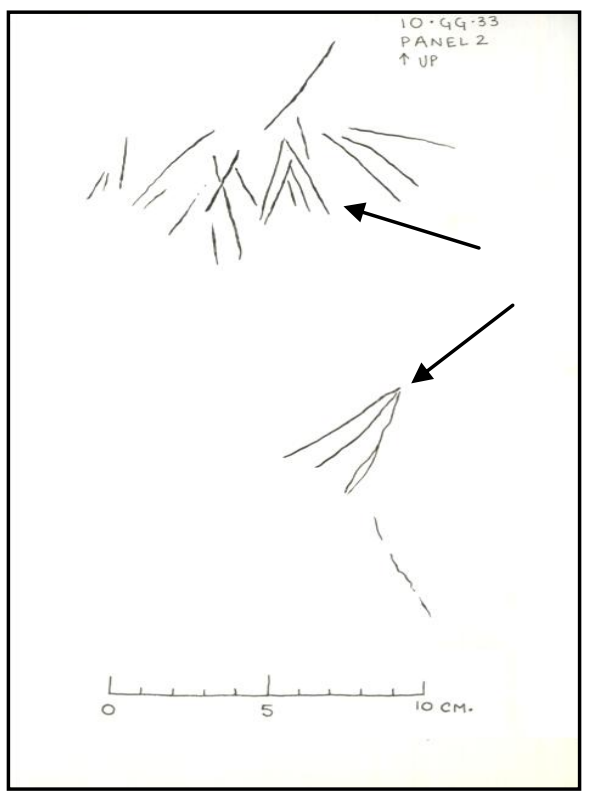

Figure 3.8. motif 8, 10GG33, panel 2. 


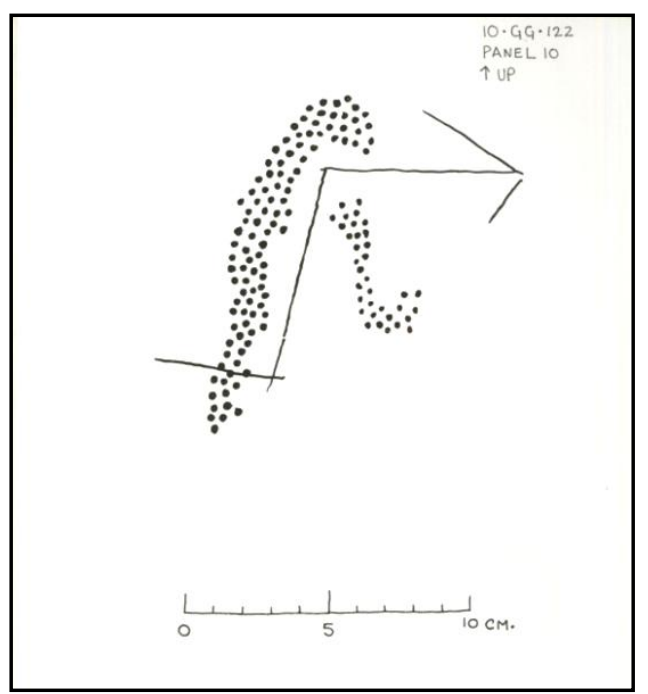

Figure 3.9. motif 9, 10GG122, panel 10.

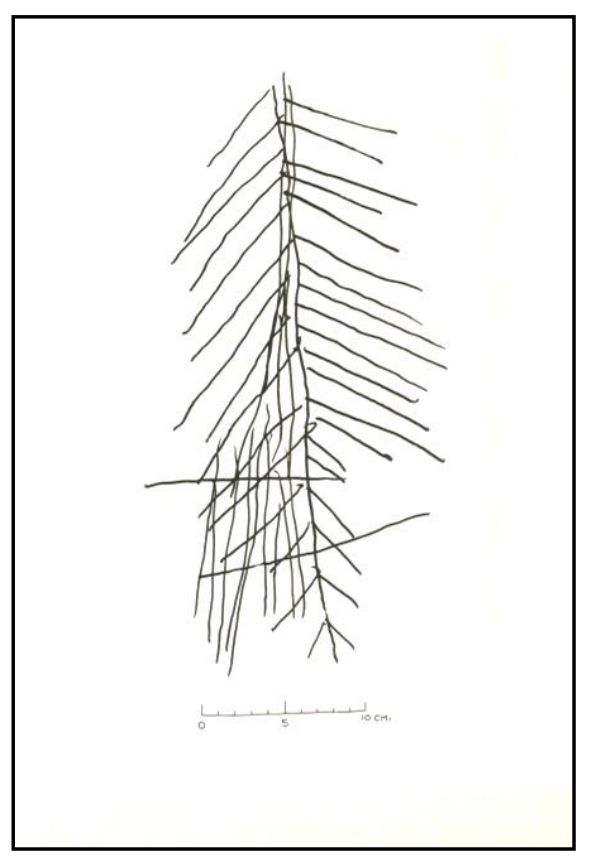

Figure 3.11. motif 11, 10GG565, panel 14.

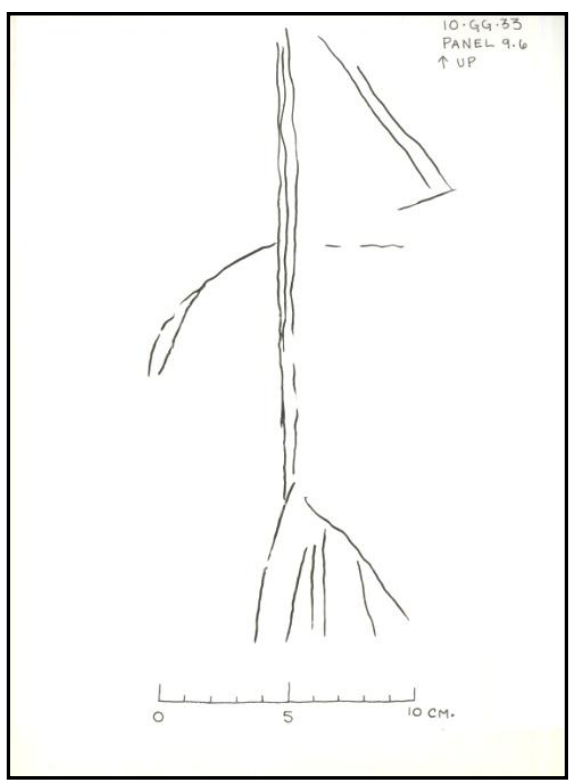

Figure 3.10. motif 10, 10GG33, panel 9.6.

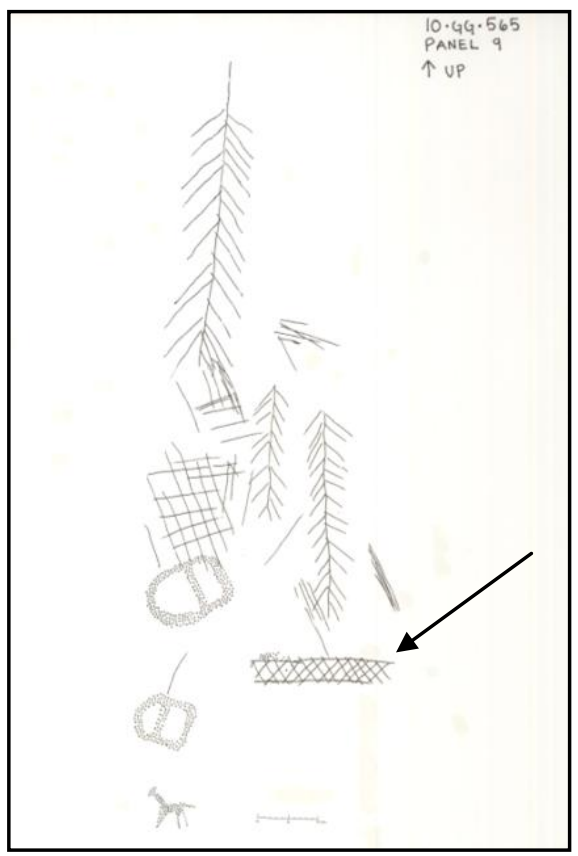

Figure 3.12. motif 12, 10GG565, panel 9. 


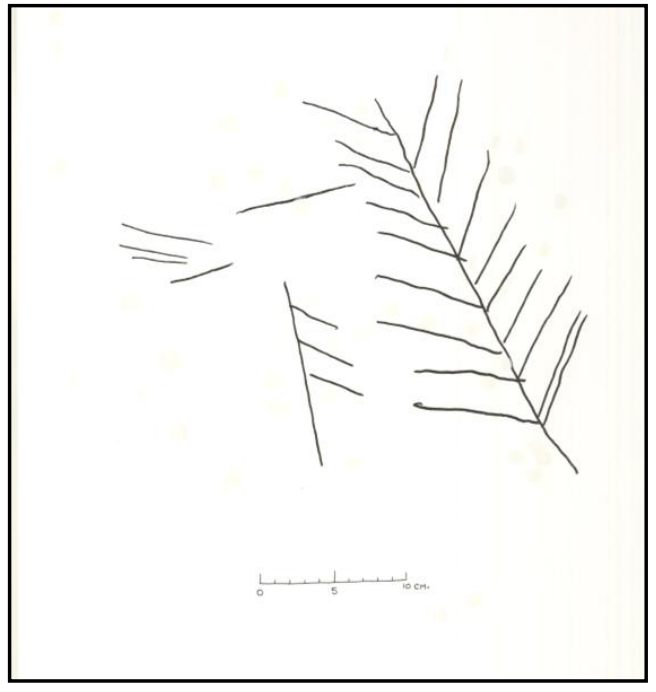

Figure 3.13. motif 13, 10GG565, panel 12.

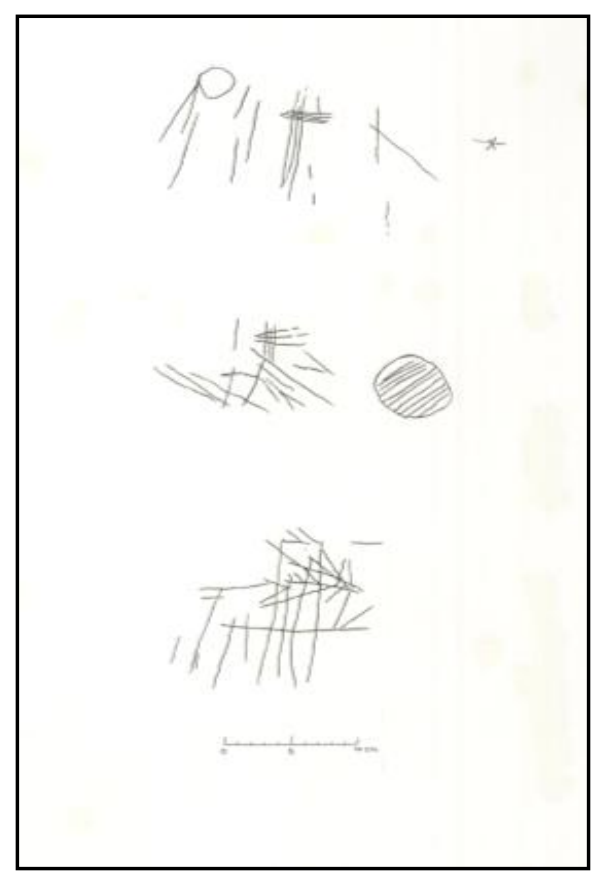

Figure 3.15, motif 15 and 16, 10GG33, panel 9.7.

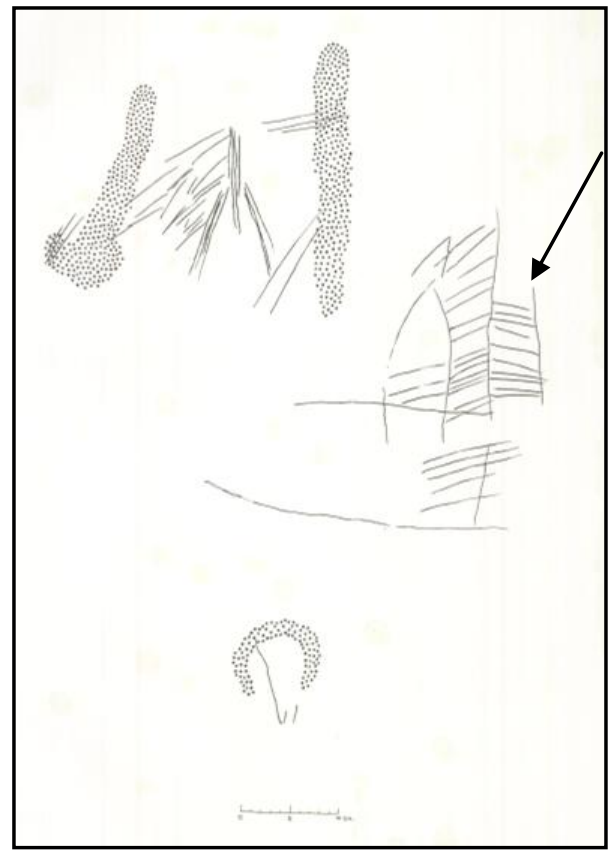

Figure 3.14. motif 14, 10GG33, panel 15 .

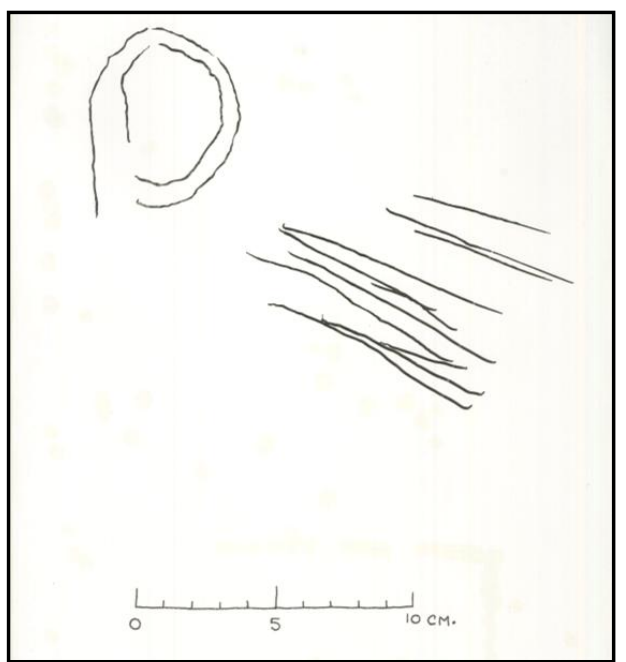

Figure 3.16., motif 17, 10GG33, panel 9.7. 
Table 3.2. Scratched Petroglyph Motifs in the Bennett Hills.

\begin{tabular}{|r|r|r|}
\hline \multicolumn{1}{|c|}{ Motif No. } & \multicolumn{1}{|c|}{ Total } & Percentage \\
\hline 1 & 56 & $17 \%$ \\
\hline 2 & 15 & $5 \%$ \\
\hline 3 & 63 & $19 \%$ \\
\hline 4 & 69 & $21 \%$ \\
\hline 6 & 14 & $2 \%$ \\
\hline 7 & 8 & $22 \%$ \\
\hline 8 & 72 & $1 \%$ \\
\hline 9 & 4 & $2 \%$ \\
\hline 10 & 8 & $2 \%$ \\
\hline 11 & 5 & $1 \%$ \\
\hline 12 & 2 & $1 \%$ \\
\hline 13 & 3 & $1 \%$ \\
\hline 14 & 4 & $1 \%$ \\
\hline 15 & 1 & $1 \%$ \\
\hline 16 & 1 & $1 \%$ \\
\hline 17 & 1 & $1 \%$ \\
\hline & 326 & $100 \%$ \\
\hline
\end{tabular}

This is not an exhaustive list of all scratched motifs in the Bennett Hills.

Scratched petroglyph sites comprising Sample Two contained motifs that were not present at the sites in Sample One. Specifically, 10GG284 (figure 3.17) and 10GG738 contained scratched petroglyphs that were not present in Sample One. 


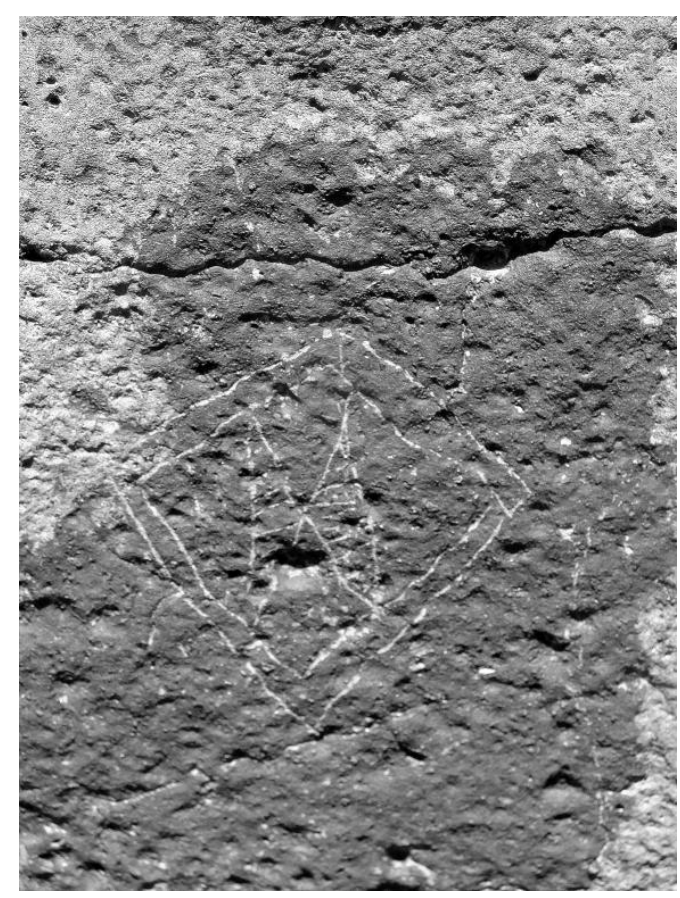

Figure 3.17. 10GG284, distinctive scratched petroglyph.

The depth and width of the scratched petroglyphs varied considerably. Variability in the quality of the scratched line suggests different types of tools and techniques were employed to manufacture scratched petroglyphs. The width and depth were not calculated because the scratches were too small to accurately measure with the naked eye. Special photographic equipment and skills would have to be used to capture and measure variation in width and depth. Generally, the scratches were shallow in depth and thin in width (figure 3.18). There were a few scratched petroglyphs that were relatively deep and thin (figure 3.19) suggesting a particularly sharp and strong tool was employed with great force, perhaps a metal knife. There were also a few scratches that were relatively thick and shallow (figure 3.20), as if they had been manufactured with a blunt tool with only slight pressure. 


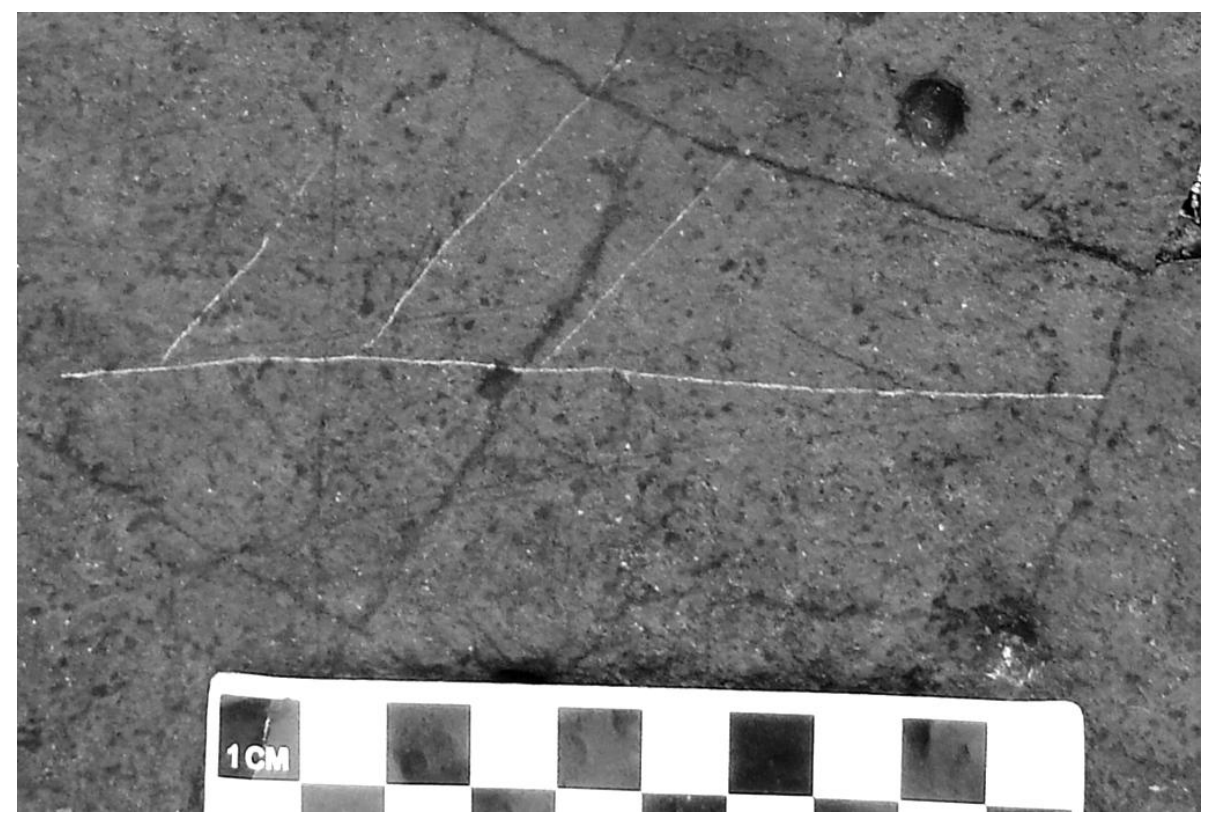

Figure 3.18. 10-GG-565, panel 2, example of the standard width and depth of scratched petroglyphs.

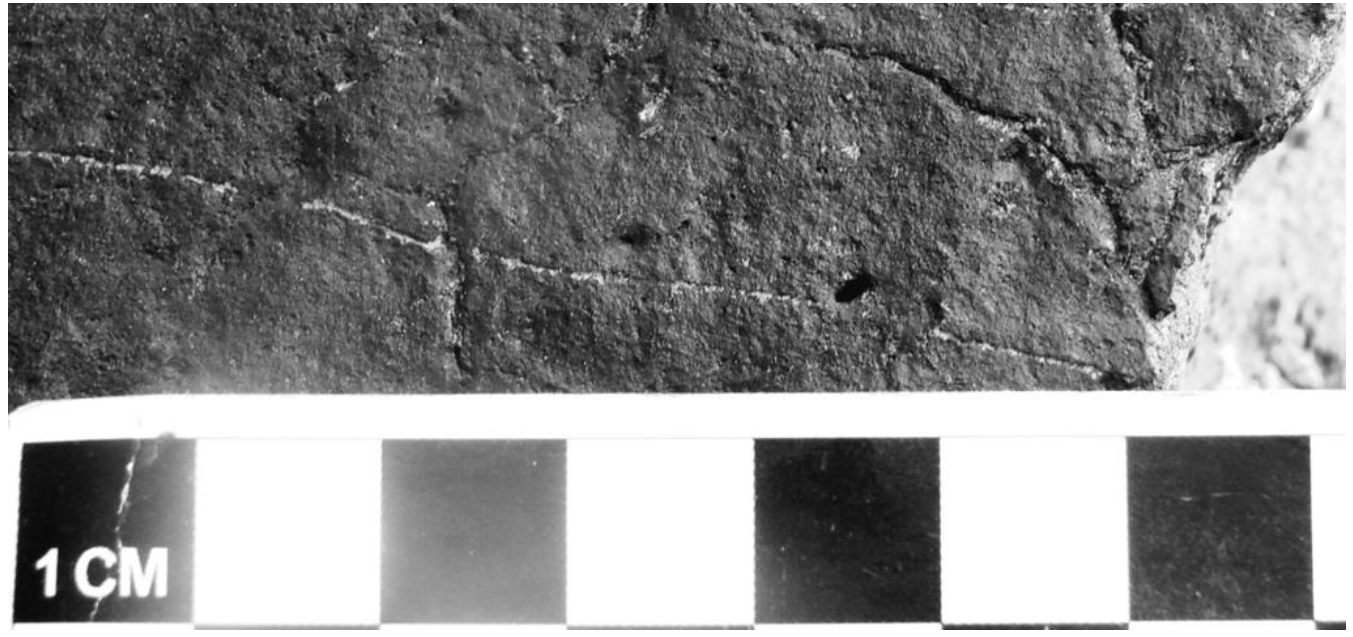

Figure 3.19. 10-GG-702, panel 6, example of a deep and thin scratched petroglyph. 


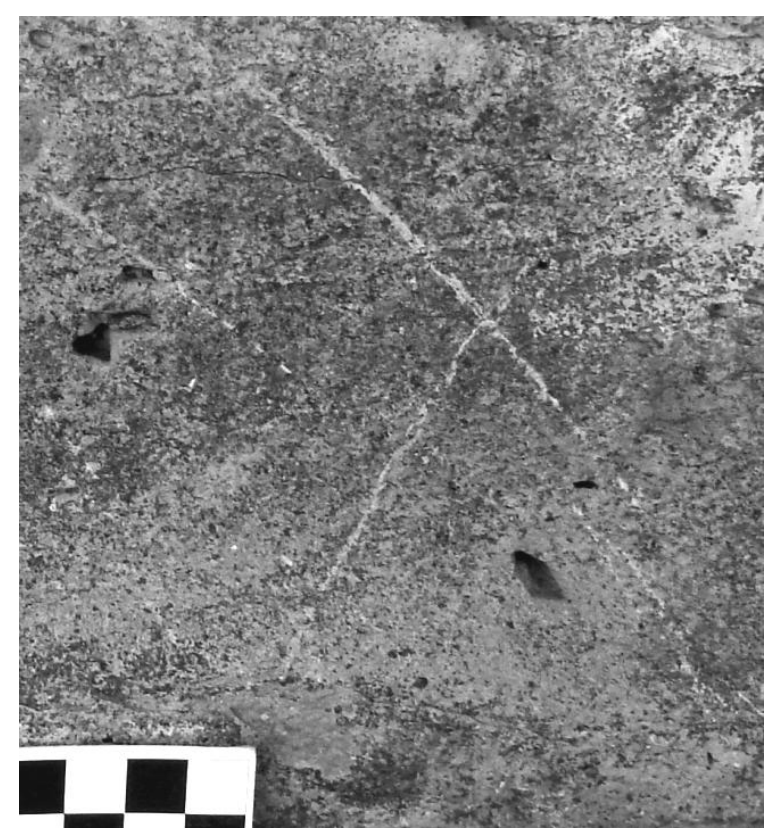

Figure 3.20. 10GG33, panel 1, example of a shallow and wide scratched petroglyph.

Scratched and pecked petroglyphs were counted at each site to quantify the proportion of scratched petroglyphs in comparison with pecked petroglyphs. Table 3.3 presents the number of petroglyph panels with either scratched petroglyphs or both scratched and pecked petroglyphs and the number of panels with only pecked petroglyphs at each site.

Among the 10 sites in Sample One there are more panels containing only pecked petroglyphs $(94,57$ percent) than panels containing either scratched petroglyphs or both scratched and pecked petroglyphs $(71,43$ percent), but the margin is not great. There are four sites (10GG33, 10GG783, 10GG565, 10GG122) that contain more panels with scratched petroglyphs or both scratched and pecked styles than panels with only pecked petroglyphs. 
Table 3.3. Quantity of Scratched and Pecked Petroglyph Panels at Each Site in the Bennett Hills.

\begin{tabular}{|l|l|l|l|l|}
\hline \multicolumn{1}{|c|}{ Site No. } & $\begin{array}{c}\text { N } \\
\text { Scratched } \\
\text { Panels }\end{array}$ & $\begin{array}{c}\text { N } \\
\text { Pecked } \\
\text { Panels }\end{array}$ & $\begin{array}{c}\text { \% } \\
\text { Scratched } \\
\text { Panels }\end{array}$ & $\begin{array}{c}\text { \% } \\
\text { Pecked } \\
\text { Panels }\end{array}$ \\
\hline 10GG569 & 2 & 8 & $20 \%$ & $80 \%$ \\
\hline 10GG165 & 2 & 6 & $25 \%$ & $75 \%$ \\
\hline 10GG122 & 12 & 6 & $56 \%$ & $44 \%$ \\
\hline 10GG474 & 1 & 10 & $9 \%$ & $90 \%$ \\
\hline 10EL1934 & 1 & 1 & $50 \%$ & $50 \%$ \\
\hline 10GG702 & 10 & 31 & $24 \%$ & $74 \%$ \\
\hline 10GG565 & 14 & 9 & $61 \%$ & $39 \%$ \\
\hline 10GG783 & 5 & 2 & $71 \%$ & $29 \%$ \\
\hline 10GG782 & 2 & 5 & $29 \%$ & $71 \%$ \\
\hline 10GG33 & 20 & 16 & $57 \%$ & $43 \%$ \\
\hline Sum & $\mathbf{6 9}$ & $\mathbf{9 4}$ & $\mathbf{4 2 \%}$ & $\mathbf{5 8 \%}$ \\
\hline
\end{tabular}

These data provide a rough estimate of the number of scratched and pecked petroglyphs in Sample One. A more exact method of quantifying would have been to count the number of individual scratched and pecked motifs at each site rather than just quantifying the panels. However, it can be very difficult and counterproductive to count individual motifs on complex petroglyph panels which may have intended to represent a single composition rather than individual motifs. Nevertheless, this information was not collected and as a result these data only provide a rough estimate of the proportion of scratched and pecked petroglyphs at each site in Sample One.

\section{Contextual Attributes}

This research examines a number of contextual associations between scratched petroglyphs and other archaeological and natural phenomena. At each site in Sample One, elevation, distance to water, aspect, site type, and significant geological features 
were recorded to analyze broad associations between the landscape and scratched

petroglyphs. Smaller scale contextual associations include aspect and inclination of the rock art panel, artifact and feature associations, and impacts.

The 10 sites comprising Sample One were reviewed to gather data about the site, where it is located on the landscape, and other geological features. Elevation, distance to water, aspect, site type, and the geological feature on which the rock art occurs were determined using data from the site records (table 3.4).

Table 3.4. Scratched Petroglyph Site Data.

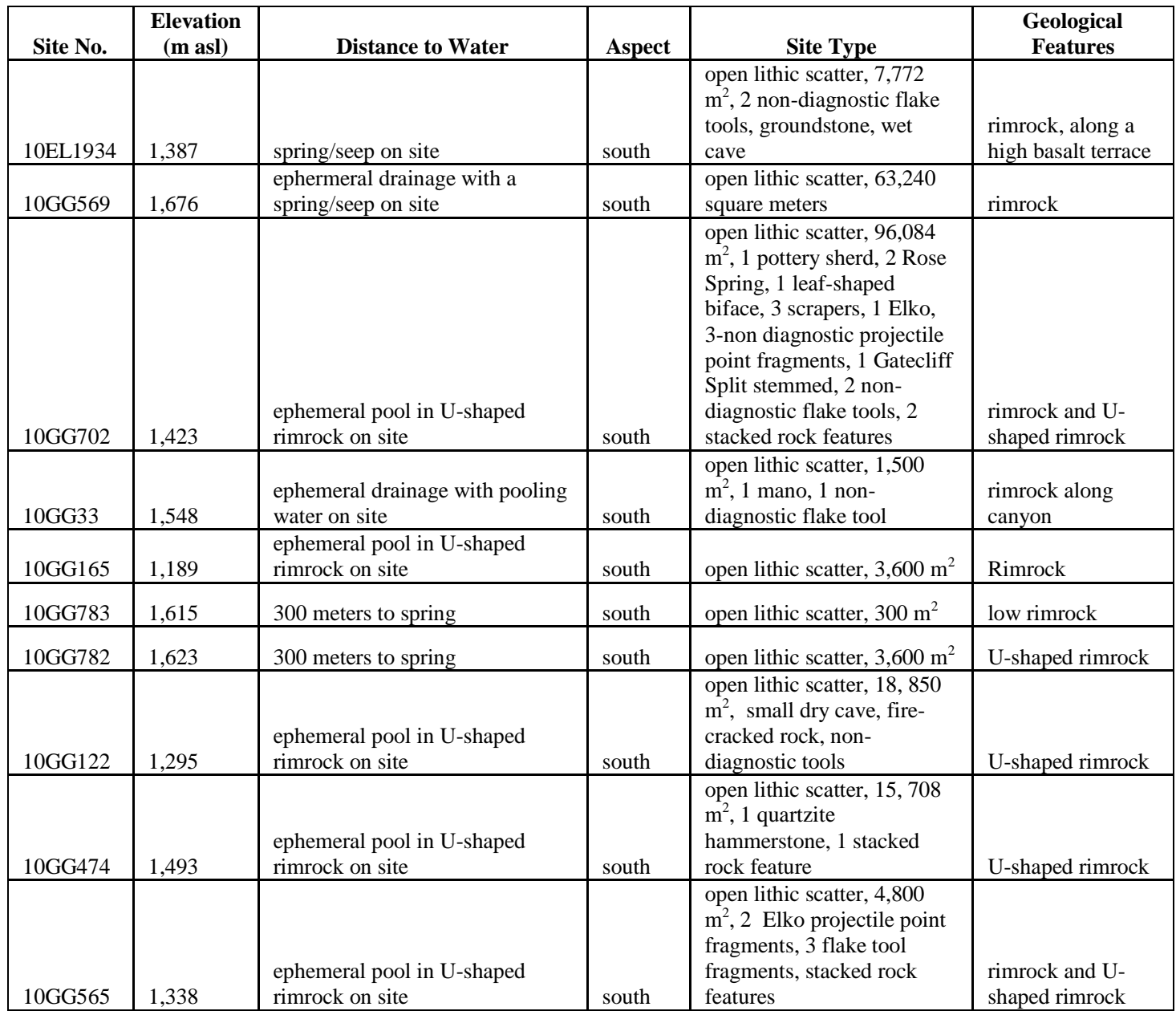


The sites in Sample One range between 1,188 to 1,676 m asl (the study area ranges between 762 and 2,255 m asl). Eight of the 10 (80 percent) sites in Sample One have water on site. Two of the 10 sites have water within $300 \mathrm{~m}$. It is significant to note that ephemeral water sources were also included in these data. It is likely that if a site is located at an ephemeral water source then it was occupied when that source held water. Furthermore, water sources would have been easier to come by in the spring en route to the Camas Prairie, than in the fall on the return trip to the Snake River. Additional investigations should focus on current water availability versus water sources that may or may not have been available during portions of the Holocene. All 10 sites were located on south facing slopes. All sites in Sample One have an open lithic scatter component. The site size varies greatly from 300 to $96,084 \mathrm{~m}^{2}$. Obsidian, ignimbrite, quartzite, and chert are common lithic materials. Flake tools include scrapers, bifaces, and projectile points. Diagnostic projectile point types include the Gatecliff Split Stemmed dating to the Early Archaic (4,000-2,000 B.C.), Elko Corner-Notched diagnostic of the Middle Archaic (1,500 B.C. - A.D. 500), and Rose Spring representative of the Late Archaic (A.D. 500 to the contact era). One site has a single potsherd, three sites contain stacked rock features, three sites contain ground stone, one site contains fire cracked rock, and two sites contain a cave. Five out of the ten sites in Sample One have rock art located along a rimrock geological feature. The other five sites have rock art located along a Ushaped rimrock with a waterhole. This data provides valuable insight into the environment, setting, and context in which scratched petroglyphs were produced. 
Table 3.5. Artifact and Feature Association with Scratched Petroglyph Panels in the Bennett Hills.

\begin{tabular}{|l|l|l|}
\hline $\begin{array}{l}\text { Feature/Artifact } \\
\text { Association }\end{array}$ & No. of Panels & Percentage \\
\hline None & 29 & $34 \%$ \\
\hline Overhang & 5 & $6 \%$ \\
\hline Flakes & 34 & $39 \%$ \\
\hline Cave & 7 & $8 \%$ \\
\hline tool fragment & 5 & $6 \%$ \\
\hline projectile point & 4 & $45 \%$ \\
\hline
\end{tabular}

The majority (40, 58 percent) of scratched petroglyph panels were located within 10 meters of an artifact or feature (table 3.5). The most common association is that of flakes located near 34 (49 percent) panels. Other artifacts and natural features, listed in order of declining frequency (table 3.5) include caves, tool fragments, overhangs, and projectile points.

Additional information was collected to further contextualize scratched petroglyphs on a smaller scale. Aspect, inclination, and impacts were recorded at each panel. A majority of scratched petroglyph panels $(52,75$ percent) face south, southeast, or east (table 3.6).

Table 3.6. Aspect of Scratched Petroglyph Panels in the Bennett Hills.

\begin{tabular}{|l|l|l|}
\hline Aspect & $\begin{array}{c}\text { No. of } \\
\text { Panels }\end{array}$ & Percentage \\
\hline SE & 15 & $22 \%$ \\
\hline E & 15 & $22 \%$ \\
\hline NE & 3 & $4 \%$ \\
\hline W & 4 & $6 \%$ \\
\hline SW & 5 & $7 \%$ \\
\hline S & 22 & $32 \%$ \\
\hline NW & 1 & $0 \%$ \\
\hline N & 1 & $1 \%$ \\
\hline $\begin{array}{l}\text { Facing Up }\left(0^{\circ}\right. \\
\text { horizontal } \\
\text { surface })\end{array}$ & 4 & $6 \%$ \\
\hline
\end{tabular}


A majority of rock panels on which scratched petroglyphs occur are between a $90^{\circ}$ to $45^{\circ}$ angle (table 3.7$)$.

Table 3.7. Inclination of Scratched Petroglyph Panels in the Bennett Hills.

\begin{tabular}{|l|l|l|}
\hline Inclination & No. of Panels & Percentage \\
\hline $90-45^{\circ}$ & 64 & $94 \%$ \\
\hline $44-0^{\circ}$ & 5 & $7 \%$ \\
\hline
\end{tabular}

Various natural impacts were identified and recorded at scratched petroglyph panels (table 3.8).

Table 3.8. Impacts at Scratched Petroglyph Panels in the Bennett Hills.

\begin{tabular}{|l|l|l|}
\hline Impacts & No. of Panels & Percentage \\
\hline spalling/chipping & 8 & $11 \%$ \\
\hline Lichen & 52 & $69 \%$ \\
\hline Moss & 1 & $1 \%$ \\
\hline None & 14 & $19 \%$ \\
\hline
\end{tabular}

Only 14 (6 percent) panels were free of impacts. All impacts were naturally occurring rather than human caused, including lichen and moss growth, and chipping and weathering of the rock surface. Lichen growth is the most common impact identified at fifty-two (70 percent) of the petroglyph panels. This information is important for future monitoring and management of petroglyph sites.

\section{Hypothesis Testing}

\section{Associations between Scratched and Pecked Petroglyphs}

Scratched petroglyphs occur in independent and isolated contexts but they are also often associated with other pecked petroglyph styles. First, data was collected to identify how many scratched petroglyphs are associated with pecked petroglyph styles 
and how many occur in isolated contexts. Forty (58 percent) panels contain scratched petroglyphs that are associated with pecked or abraded motifs. Twenty-nine (42 percent) panels contain scratched petroglyphs that are freestanding motifs, not associated with other abraded or pecked petroglyphs. These data suggest that scratched petroglyphs are not exclusively related to pecked petroglyph styles, but also occur in independent contexts.

There are various hypotheses that deal with the interaction between scratched and pecked petroglyph styles. These hypotheses suggest that scratched and pecked petroglyphs are consistently manufactured in a specific temporal order. In Sample One all of the scratched motifs that are associated with pecked petroglyphs are completely visible suggesting scratched petroglyphs are later and superimposed over earlier pecked petroglyphs. There are no instances where scratched petroglyphs appear to be obliterated by pecked petroglyphs. However, it is difficult to determine the time elapsed between when the pecked petroglyph was manufactured and when the scratched petroglyph was superimposed over the pecked petroglyph. Scratches could have been drawn immediately after the pecked petroglyph was manufactured or hundreds of years later.

The petroglyph style and motif associated with scratches were recorded to determine whether scratched petroglyphs are associated with specific pecked or abraded motifs (table 3.9). 
Table 3.9. Pecked and Abraded Petroglyphs Associated with Scratched Petroglyphs.

\begin{tabular}{|l|l|l|}
\hline Associated Petroglyphs & No. of Motifs & $\begin{array}{l}\text { Percentage of } \\
\text { Motifs }\end{array}$ \\
\hline Representational, Shield & 8 & $22 \%$ \\
\hline Representational, Animal & 2 & $.05 \%$ \\
\hline Representational, Figure & 7 & $19 \%$ \\
\hline Representational, Hand & 1 & $.03 \%$ \\
\hline Total Representational & $\mathbf{1 8}$ & $\mathbf{5 0 \%}$ \\
\hline Abstract, Curvilinear, half-circle & 3 & $8 \%$ \\
\hline Abstract, Curvilinear, "m"-shaped & 1 & $.03 \%$ \\
\hline Abstract, Curvilinear, "n"-shaped & 1 & $.03 \%$ \\
\hline Abstract, Curvilinear, "w"-shaped & 1 & $.03 \%$ \\
\hline Abstract, Curvilinear, "p"-shaped & 1 & $.03 \%$ \\
\hline Abstract, Curvilinear, "complex" & 1 & $.03 \%$ \\
\hline Abstract, Curvilinear, "8" & 2 & $.05 \%$ \\
\hline Total Abstract, Curvilinear & $\mathbf{1 0}$ & $\mathbf{2 7 \%}$ \\
\hline Abstract, Geometric, "x" & 2 & $.05 \%$ \\
\hline Abstract, Geometric, lines & 3 & $8 \%$ \\
\hline Abstract, Geometric, "complex" & 3 & $8 \%$ \\
\hline Total Abstract, Geometric & $\mathbf{8}$ & $\mathbf{2 2 \%}$ \\
\hline Total Abstract & $\mathbf{1 8}$ & $\mathbf{5 0 \%}$ \\
\hline Total & $\mathbf{3 6}$ & $\mathbf{1 0 0 \%}$ \\
\hline & & \\
\hline
\end{tabular}

Scratched petroglyphs do not commonly occur with any one abraded or pecked petroglyph motif. The most common associated motifs were eight (22 percent) associated representational shield figures and seven associated (19 percent) representational figures.

Data was collected to test three hypotheses concerning the intention of association between scratched and pecked petroglyphs. Researchers have identified that scratched petroglyphs serve to obliterate earlier pecked petroglyphs, enhance earlier pecked petroglyphs, and serve as a sketch that would be pecked later. Specific data was collected to test these hypotheses and gain a better understanding of why scratched and pecked petroglyphs are associated. 
The first hypothesis suggest superimposition of scratched petroglyphs over earlier pecked petroglyphs serves to obliterate earlier rock art and any power or significance it may possess Heizer and Baumhoff (1962) and Bettinger and Baumhoff (1982). Although superimposition can be easily identified, interpreting its behavioral intention is not straightforward. Data were collected to quantify and qualify superimposition of scratched petroglyphs in the Bennett Hills (table 3.10).

Table 3.10. Association and Superimposition between Scratched and Abraded or Pecked Petroglyphs.

\begin{tabular}{|l|l|l|l|}
\hline Superimposition & \multicolumn{1}{|c|}{ N } & \multicolumn{1}{|c|}{ Percentage } & \multicolumn{1}{c|}{ Figure } \\
\hline Associated & 40 & $57.97 \%$ & - \\
\hline Not Associated & 29 & $42.03 \%$ & - \\
\hline Not Superimposed & 6 & $15 \%$ & Figure 3.21 \\
\hline $\begin{array}{l}>50 \% \\
\text { Superimposed }\end{array}$ & 4 & $10 \%$ & Figure 3.22 \\
\hline $\begin{array}{l}<50 \% \\
\text { Superimposed }\end{array}$ & 22 & $55 \%$ & Figure 3.23 \\
\hline $100 \%$ Superimposed & 8 & $20 \%$ & Figure 3.24 \\
\hline
\end{tabular}

Of the 40 scratched petroglyphs that were associated with pecked petroglyphs only eight (20 percent) were 100 percent superimposed. None of those eight covered or obliterated the motif below to the point where it was unrecognizable and or obliterated. Of the 40 associated scratched petroglyph panels in Sample One 34 (85 percent) are superimposed over pecked petroglyphs. Superimposition appears to be a significant association between scratched and pecked petroglyphs. Furthermore, data collected concerning temporal order suggests scratched petroglyphs are later than and always superimposed over earlier pecked petroglyph styles. However, there is no evidence 


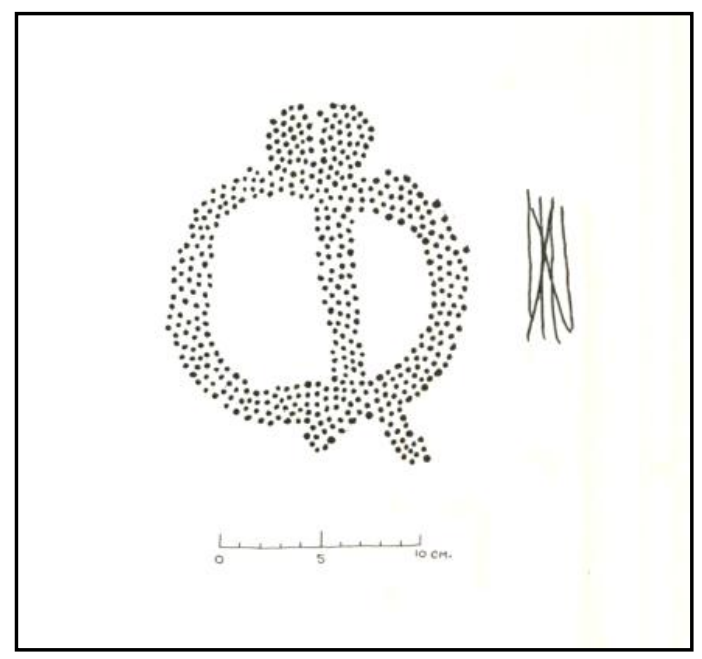

Figure 3.21. 10GG165, panel 2.

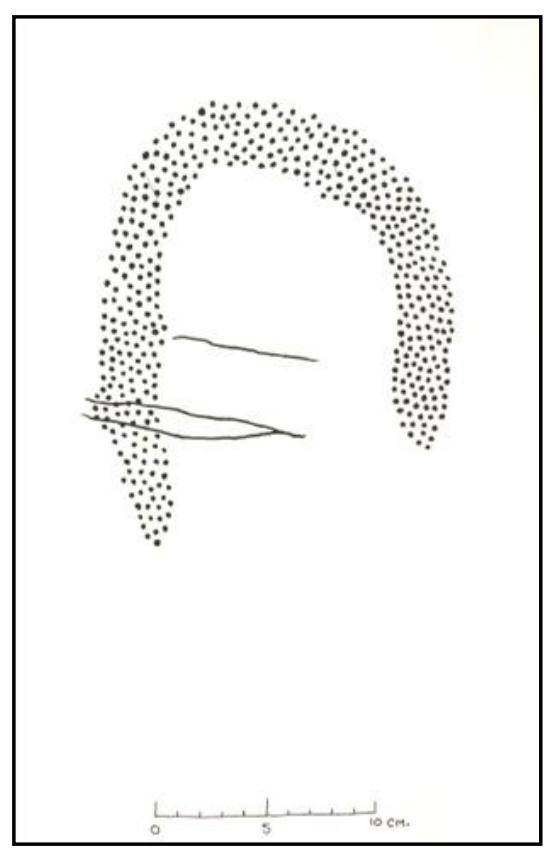

Figure 3.23. 10GG569, panel 2.

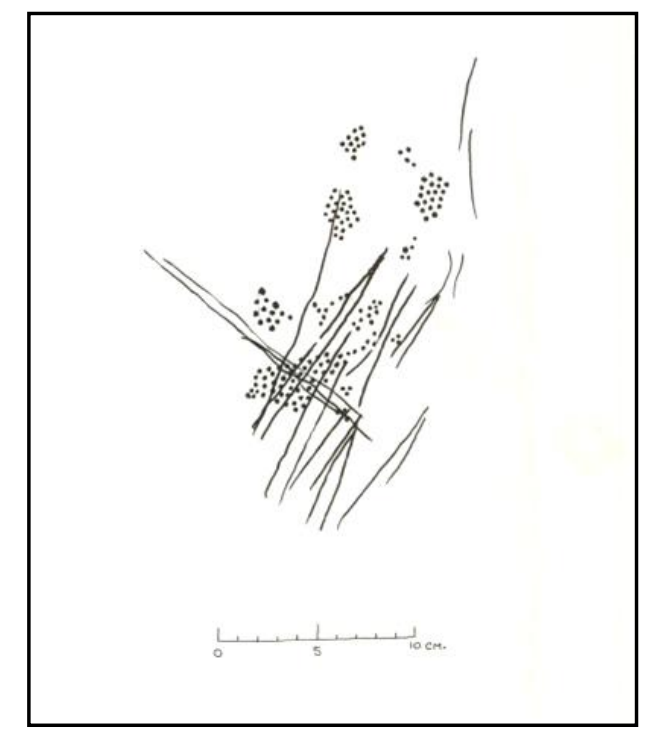

Figure 3.22. 10GG122, panel 13.

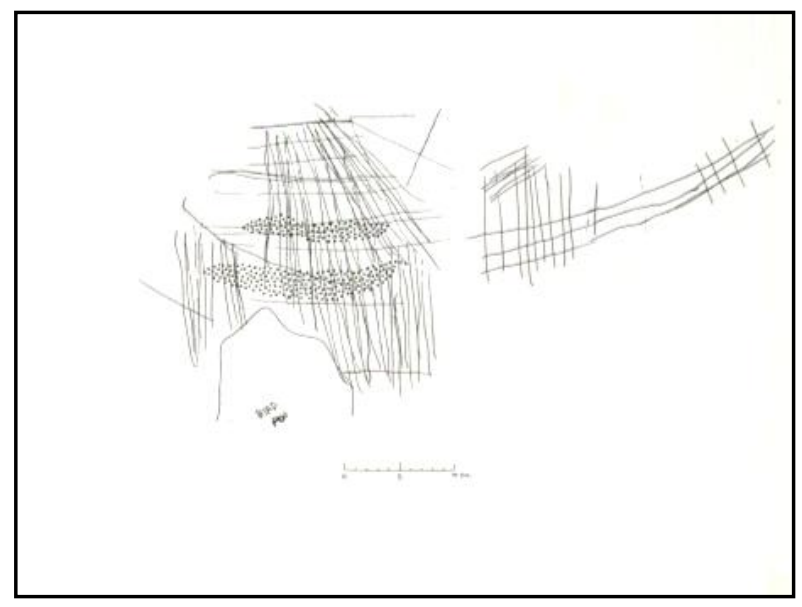

Figure 3.24. 10GG122, panel 4.

suggesting scratched petroglyphs were superimposed over earlier pecked petroglyphs to obliterate earlier rock art and any power or significance it may possess (Heizer and 
Baumhoff 1962, Bettinger and Baumhoff 1982). Superimposition is significant but the function remains unexplained.

Superimposition cannot be attributed to a lack of space on the rock surface. In all instances there is plenty of room for both motifs to coexist on the panel without one being superimposed over the other. Superimposition is intentional, rather than required due to a lack of space. Its also important to note that instances of superimposition do not cluster at a specific site. Rather instances of superimposition are present at all sites in Sample One.

The second hypothesis recognizes that scratched petroglyphs are often added to pecked petroglyphs as an embellishment. Its possible that these scratches were added after pecked petroglyphs were manufactured to alter the original purpose of the design either in a positive or negative manner (Hedges 1973). As with testing the function of superimposition, it would be difficult to test the intention of adding scratches to an earlier petroglyph. Instead, data were collected to identify and quantify these phenomena in the Bennett Hills. These data may help support Hedges (1973) hypothesis, but it cannot be used to determine why scratched petroglyphs were used to alter the original purpose of the design.

According to the hypothesis, scratched embellishments should be added sometime after the pecked motifs are manufactured. All of the scratched petroglyphs in Sample One are later and superimposed over earlier pecked petroglyph styles, consistent with this hypothesis. Of the 40 associated scratched petroglyph panels in Sample One there are 9 (22 percent) petroglyph panels that display characteristics of scratched petroglyphs being integrated into pecked petroglyph motifs as an embellishment (Hedges 1973). These 
panels are described concentrating on the characteristics that are consistent with this hypothesis. It is important to note that defining characteristics of embellishment is somewhat subjective. There is not a well defined set of characteristics to objectively identify and quantify embellishment. Rather this research makes a subjective judgment based on experience with the subject matter and careful examination of the panels. Not all of the panels are clearly examples of embellishment. Some are more convincing than others. Many of these panels include other scratched and pecked motifs that do not display characteristics of embellishment. Each of the nine scratched embellishments is associated with a different pecked motif and are unique displaying no reoccurring patterns.

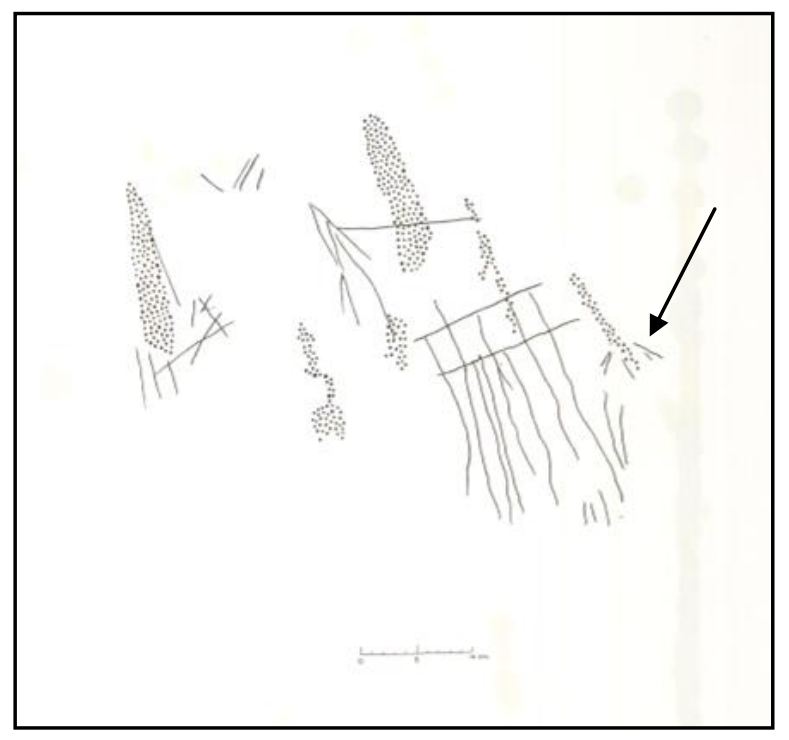

Figure 3.25. 10GG565, panel 3. A pecked vertical line with radiating scratched lines towards the bottom of the pecked motif. 


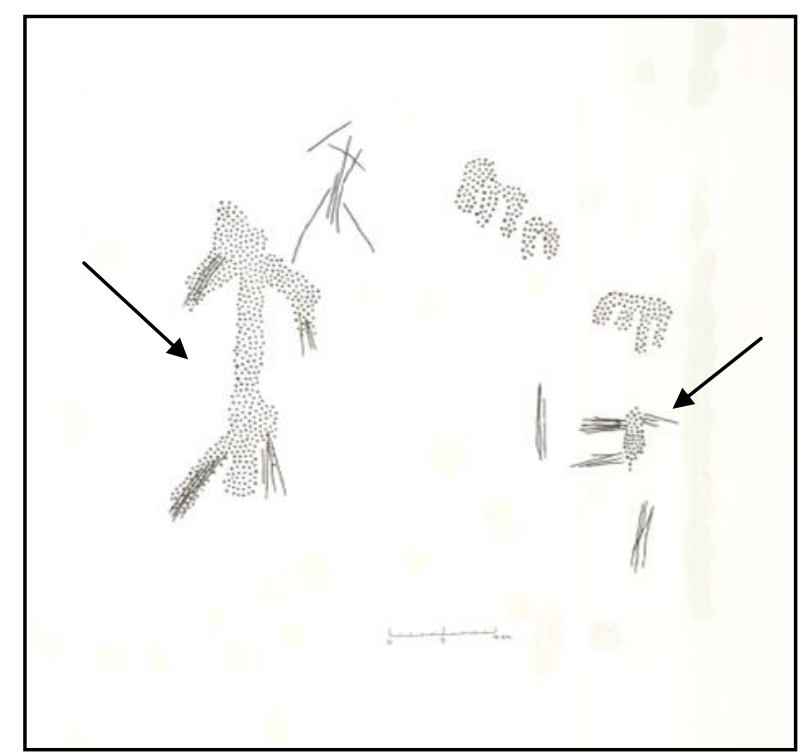

Figure 3.26. 10GG565, panel 7. Two pecked representational human figures. The arms and legs on both figures are embellished with scratches.

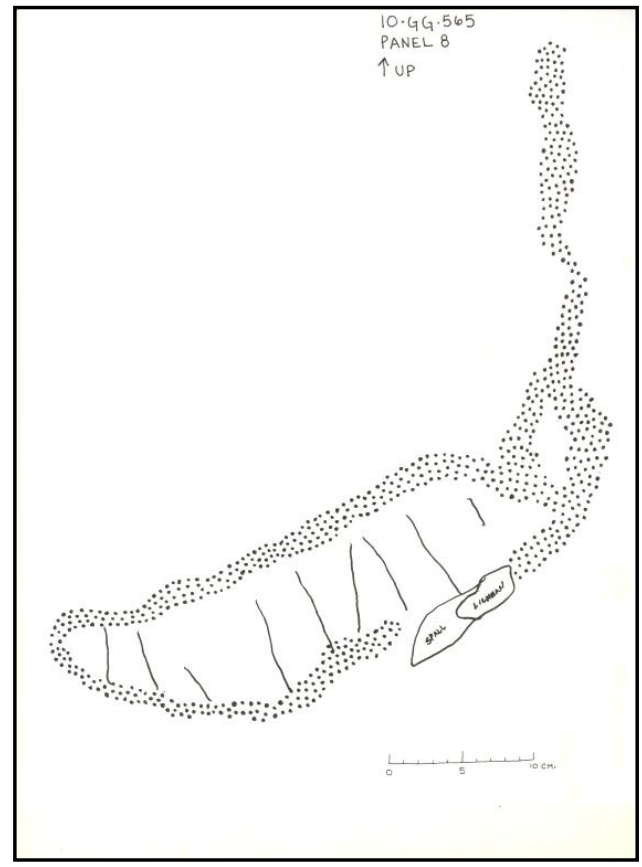

Figure 3.27. 10GG565, panel 8. A pecked motif resembling the body and neck of an animal. Within the body of the animal there are nine scratched vertical lines parallel to one another. 


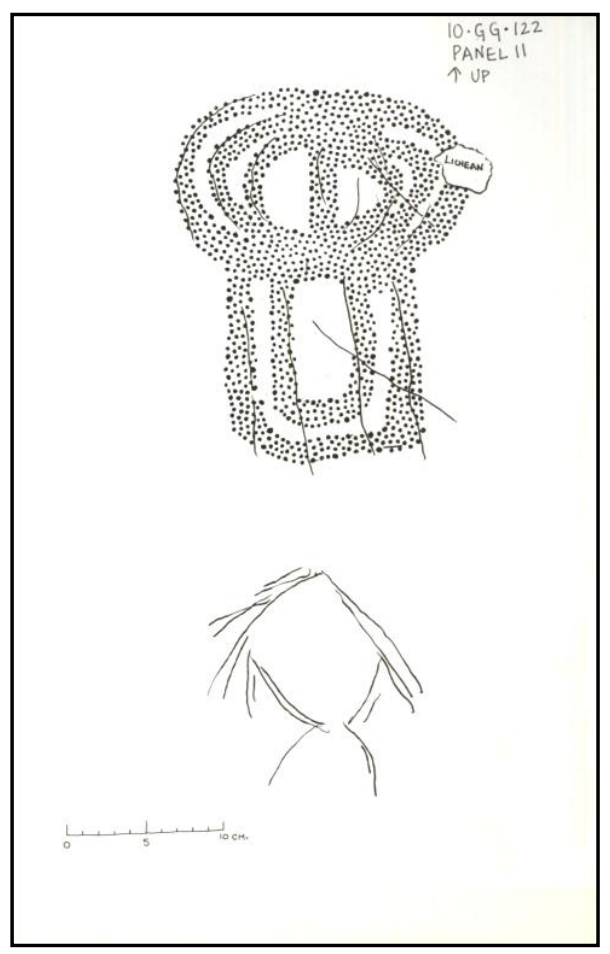

Figure 3.28. 10GG122, panel 11. A pecked abstract curvilinear motif. Scratched are traced over the pecked motif.

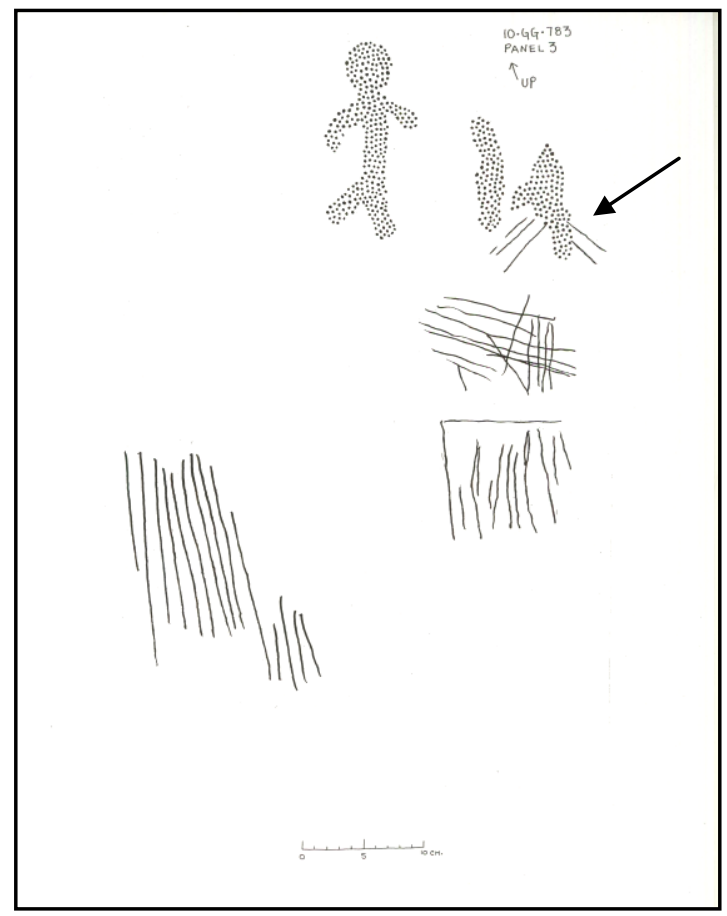

Figure 3.29. 10GG783, panel 3. An abstract pecked motif with radiating scratched lines. This association looks similar to panel three at 10GG565. 


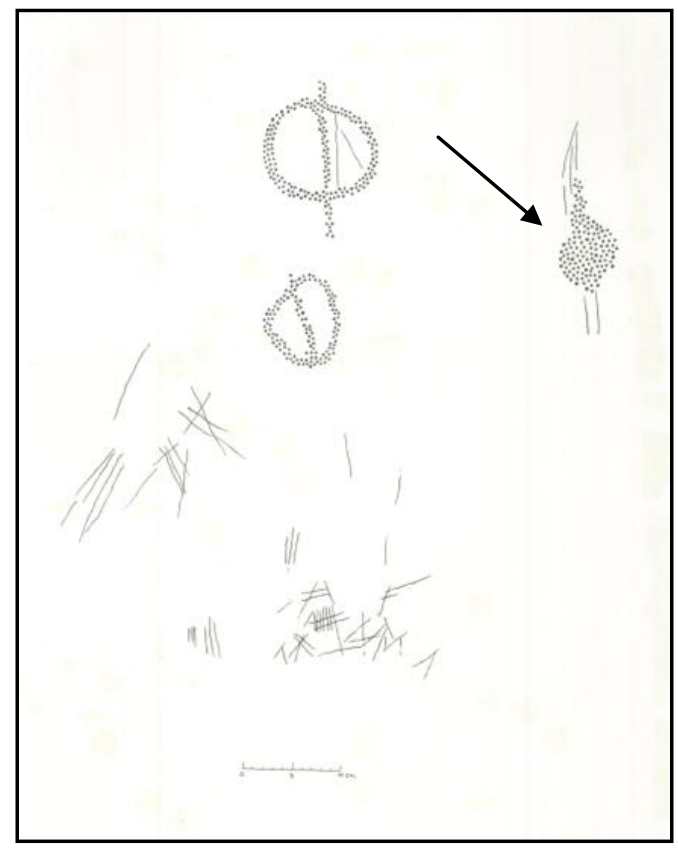

Figure 3.30. 10GG33, panel 7. An abstract circular-shaped abraded motif with scratches radiating from the top and bottom of the circle.

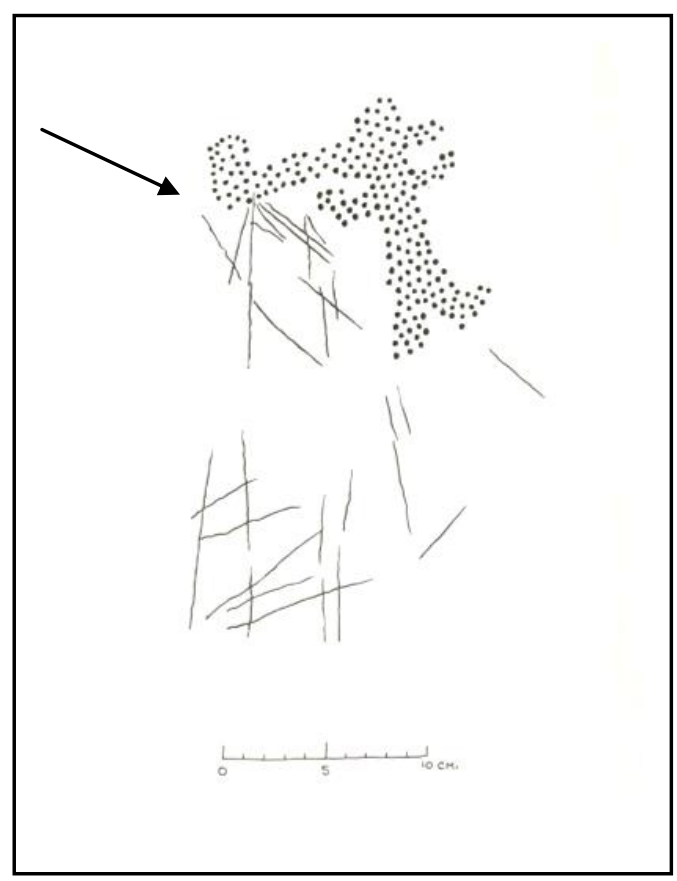

Figure 3.31. 10GG33, panel 8. A representational human figure with a headpiece. There are many scratches radiating off the bottom of the head piece. 


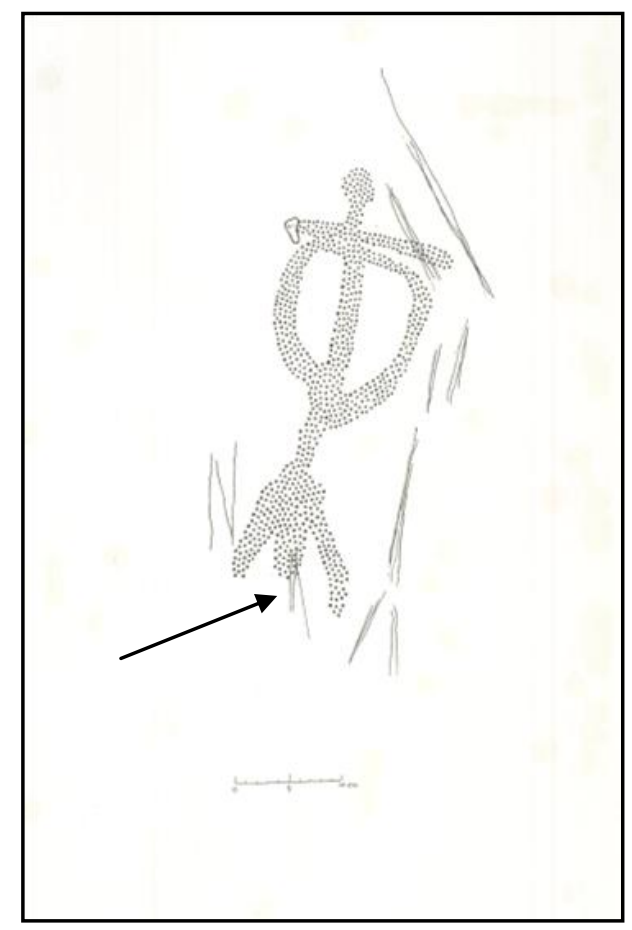

Figure 3.32. 10GG33, panel 9.5. A representational shield figure with a phallic appendage embellished with three vertical and parallel scratches.

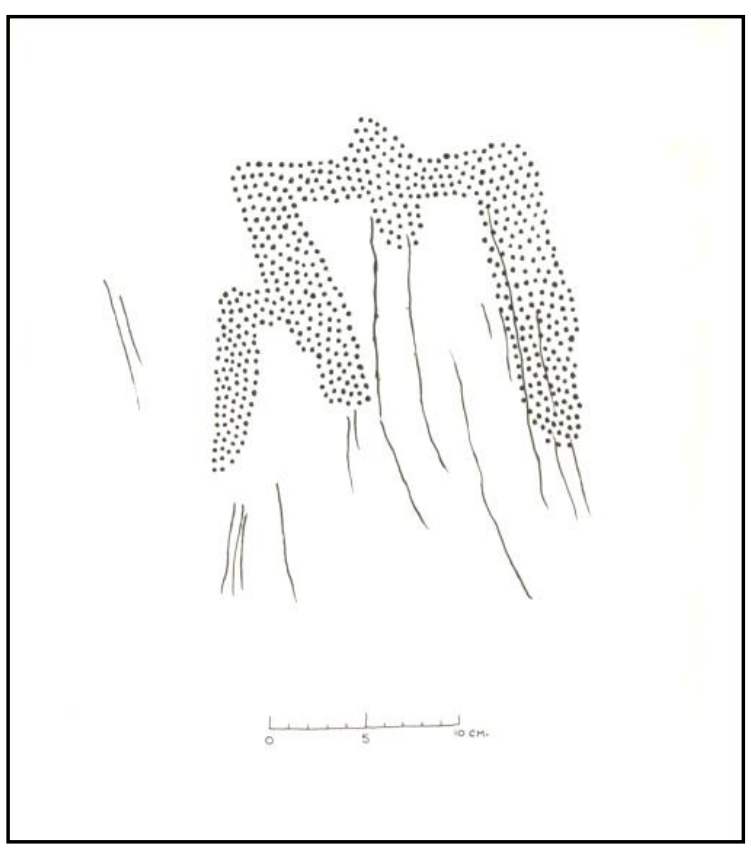

Figure 3.33. 10GG33, panel 12. A pecked abstract curvilinear motif with many scratches radiating off and tracing the curvilinear motif. 
Only 22 percent of the associated scratched petroglyphs panels in Sample One display characteristics in support of this hypothesis. All of the associated scratched petroglyphs in Sample One are clearly not added to pecked petroglyphs as an embellishment. However, nine scratched petroglyph panels can be interpreted using this hypothesis.

The third hypothesis posits that Scratched petroglyphs are a sketch or pre-form to plan a design that would be pecked or abraded later (Turner 1971; Pilles 1975). This phenomena is apparent when the design is not completed or the artist strays for the original scratched outline. There are three ( 8 percent) petroglyph panels that display characteristics in support of this hypothesis. These panels are described concentrating on the characteristics that are consistent with this hypothesis. These panels display characteristics of pre-forms and can possibly be interpreted using this hypothesis. Two of these panels include other scratched or pecked motifs that do not display characteristics of a sketch or pre-form.

Panel 9.6 at 10GG33 displays a scratched representational human figure. There are no associated pecked motifs (figure 3.34). The figure is often executed using pecking but rarely scratched. Perhaps the scratched figure served as an outline for later pecking or abrading that never occurred. 


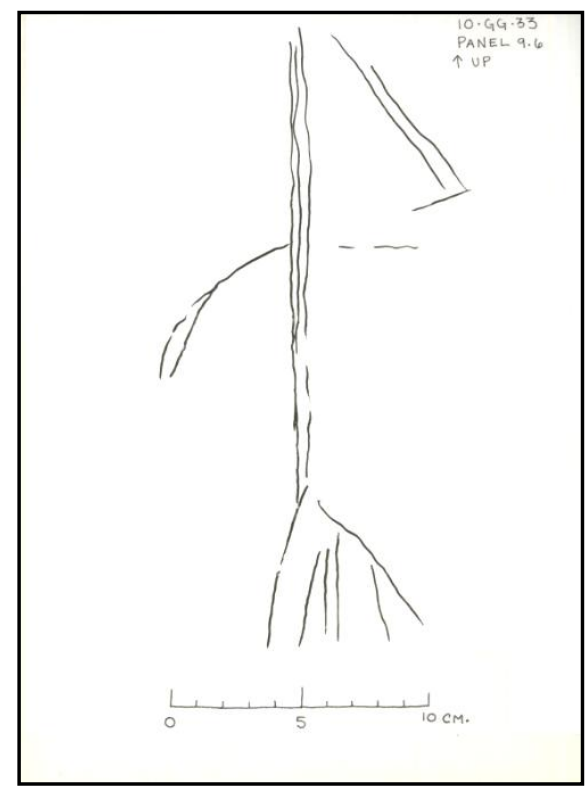

Figure 3.34. 10GG33, panel 9.6.

Panel 16 at 10GG33 also displays a scratched representational human figure, but a pecked circle for a head (figure 3.35). The scratched body could have served as an outline for later pecking that never occurred or perhaps the artist intentionally designed a scratched figure with a pecked head. 


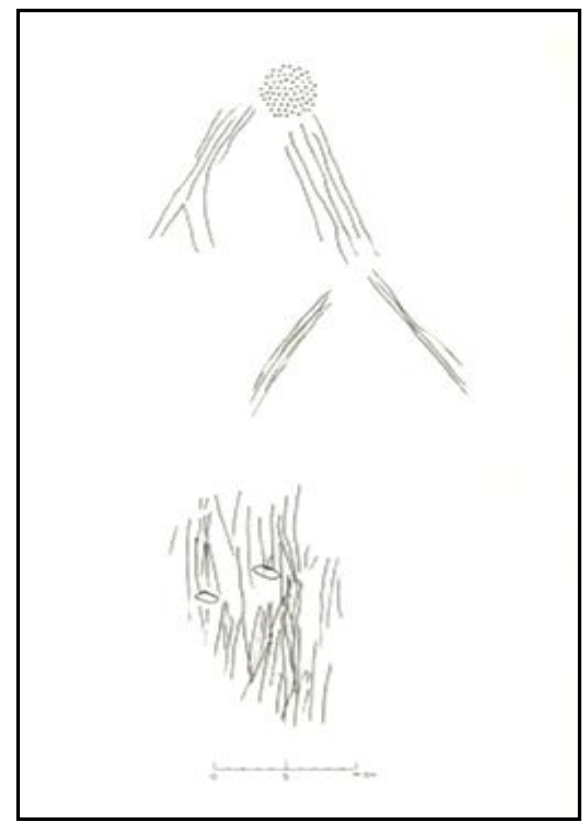

Figure 3.35. 10GG33, panel 16.

Panel seven at 10GG565 displays a scratched representational human figure.

There are no associated pecked motifs (figure 3.36). The figure is often executed using pecking or abrasion, but rarely scratched. Perhaps the scratched figure served as an outline for later pecking or abrading that never occurred.

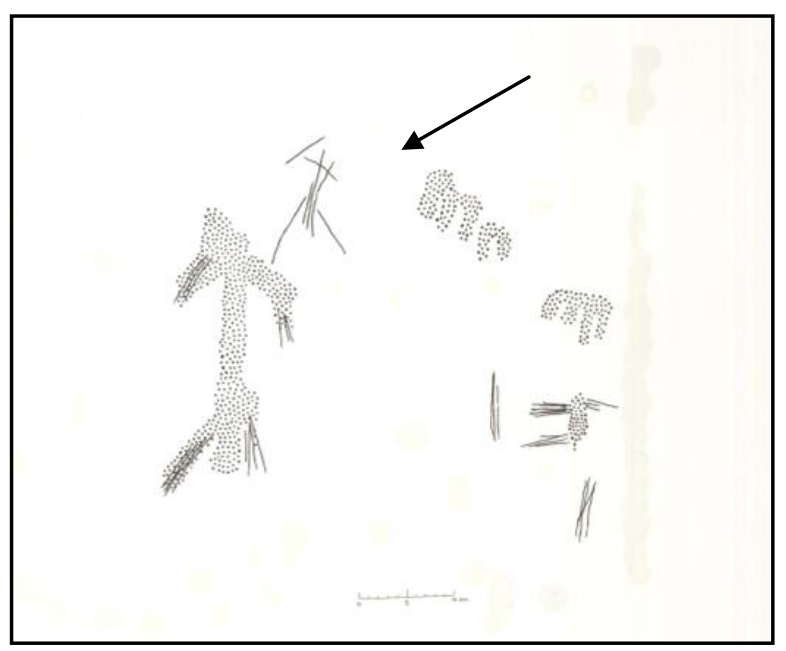

Figure 3.36. 10GG565, panel 7. 
All three of the panels displaying characteristics consistent with this hypothesis are scratched human figures. This motif is often pecked in the Bennett Hills. These panels may represent occurrences where scratched outlines were never completed with pecking, although there is no way of knowing if pecking would have followed. A scratched figure partially completed by pecking would help prove this theory, but was not encountered during this study. Of these three panels there are no instances where the scratches are superimposed over pecked motifs or vice versa, thus no data is available concerning the temporal order of scratching and pecking. Heizer and Baumhoff (1962) also recognized the possibility for scratched petroglyphs to serve as rough pattern for pecked petroglyphs, but dismiss the idea suggesting that scratched petroglyphs usually appear to be later than pecked petroglyphs. Only 4 percent of the panels display characteristics of pre-form or tracing, providing very little support for this hypothesis in the Bennett Hills.

\section{Scratched Stones}

This thesis also examines hypotheses suggesting associations between scratched rock art and other archaeological phenomena. The fourth hypothesis examines parallels between portable scratched stones and scratched rock art on non-portable rock surfaces (Pilling 1957; Santini 1974; Pilles 1975; Moriorty 1982; Christensen 1992). It is possible that if scratched petroglyphs and stones were found to be stylistically similar then one could argue that they share similar social functions (Pilling 1957). This may bolster our understanding of both scratched stones and petroglyphs. Data were collected in the Bennett Hills to determine if scratched petroglyphs in that area are comparable to 
scratched stones throughout the Great Basin. Scratched petroglyphs in the Bennett Hills were compared to three assemblages of scratched stones from the Great Basin.

\section{Assemblage 1, Huntley and Nance (1977), Plew (1976), Arkush (2011)}

The first is a small collection of 14 scratched stones from southern Idaho (Plew 1976; Huntley and Nance 1980; Arkush 2011). Although the collections are small, they are significant in being adjacent to the Bennett Hills.

The first specimen is a quartzite cobble from Camas Creek drainage of south central Owyhee County, Idaho (figure 3.37). The stone has three large flakes removed from one end. On the end with removed flakes there are six parallel scratches ranging from 1 to $2 \mathrm{~cm}$ in length. Plew (1976) speculates that the cobble was used as part of a game or form of gambling.

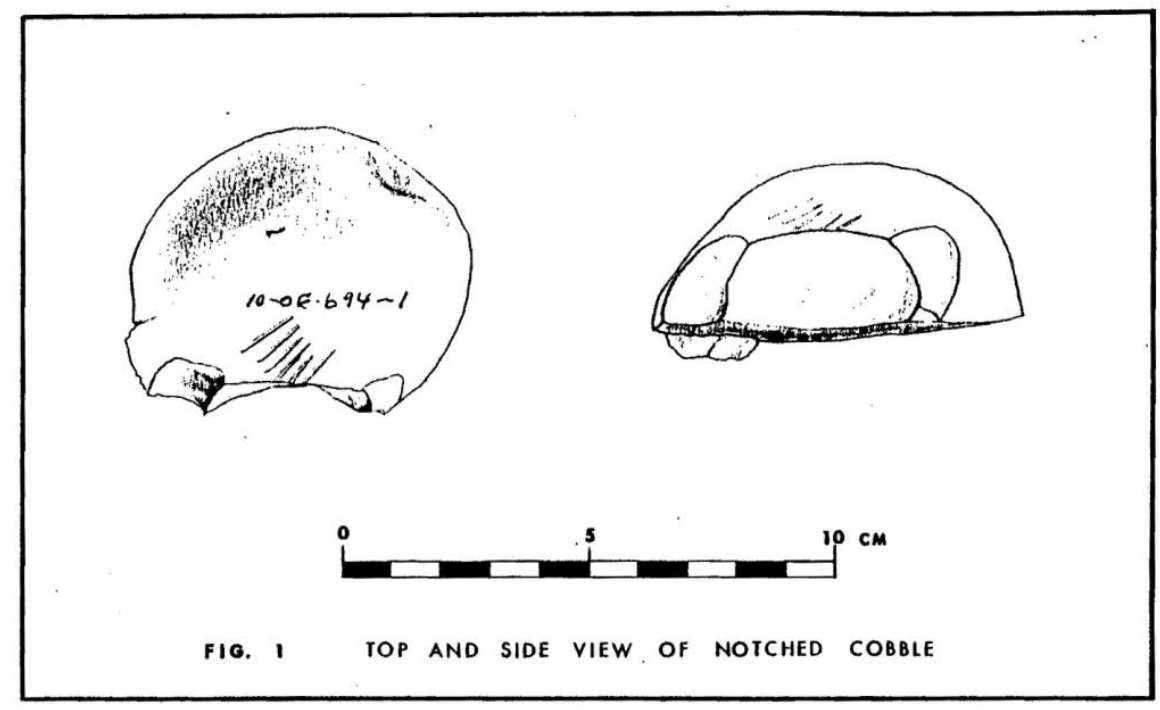

Figure 3.37. Specimen one (Plew 1976).

The second specimen is a flat grey cobble, $11.5 \mathrm{~cm}$ long, $7.6 \mathrm{~cm}$ wide, and 2 $\mathrm{cm}$ thick (figure 3.38). Parallel lines are incised on the edge of the cobble. The lines range from 1 to $8 \mathrm{~mm}$ in length and vary in width and depth. The specimen was located 
near Coyote Lake, Malheur County, Oregon. Huntley and Nance (1980) speculate the stone was the product of utilitarian use.

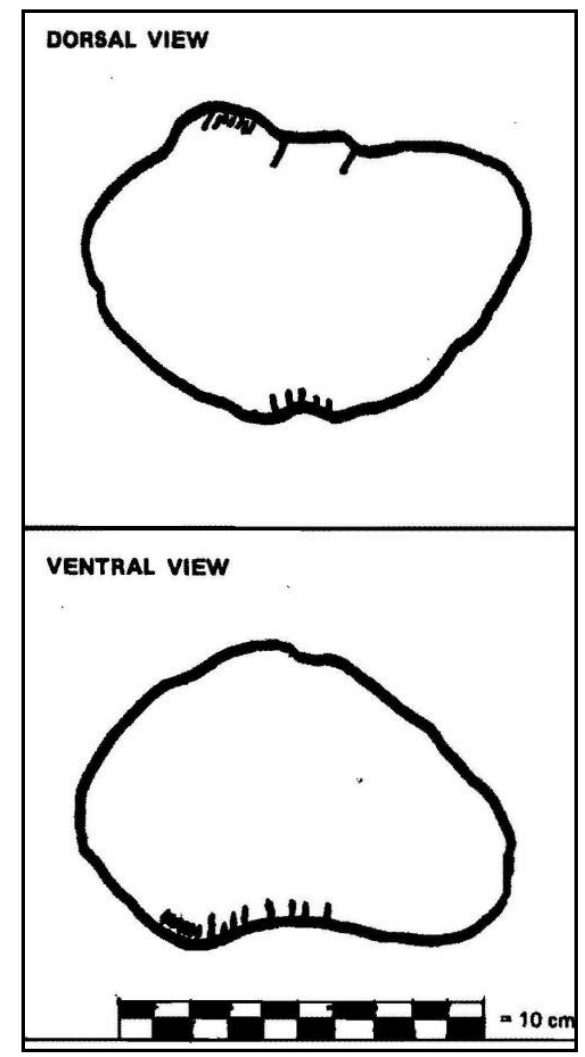

Figure 3.38. Specimen two (Huntley and Nance 1980).

The third specimen is a smooth, round, and flat incised quartzite cobble, $9 \mathrm{~cm}$ in length and $6 \mathrm{~cm}$ in width (figure 3.39). There are eight lengthwise incised lines, $2 \mathrm{~mm}$ apart, and $3.5 \mathrm{~mm}$ in length. The stone was recovered from a prehistoric campsite along Jordan Creek, a tributary of Washington Gulch of the Owyhee Mountains, located in the southwestern corner of Idaho. 


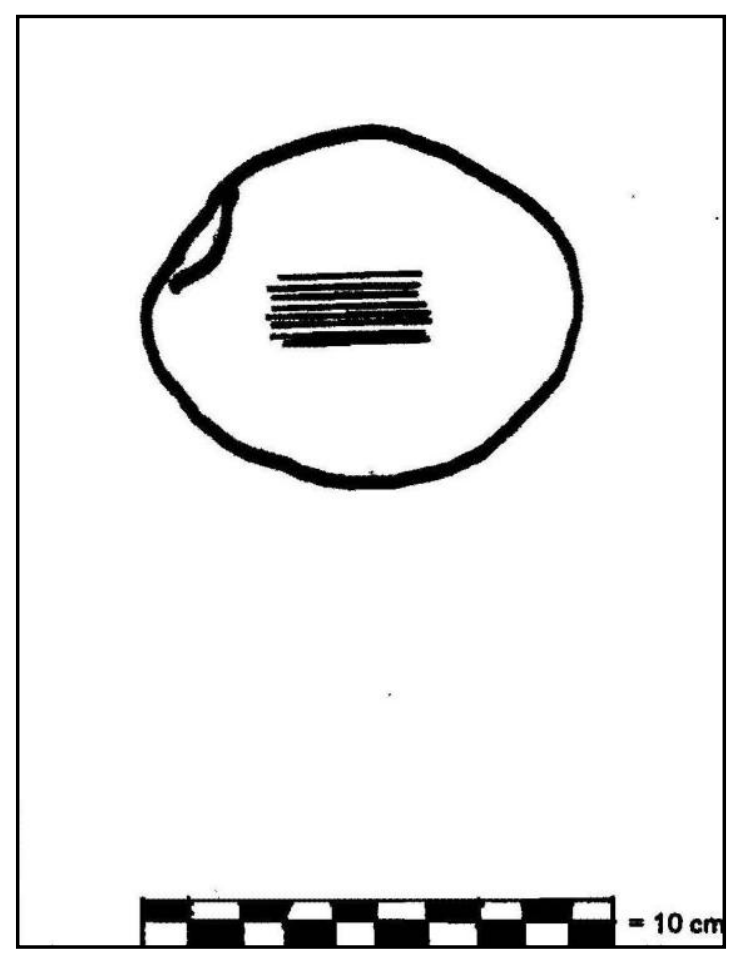

Figure 3.39. Specimen three (Huntley and Nance 1980).

The fourth specimen is a highly polished dense, fine grained, elongated, semicylindrical cobble (figure 3.40). The design is a $3.5 \mathrm{~cm}$ wide, $5 \mathrm{~cm}$ long rectangular crosshatch, comprised of 10 parallel lines bisecting 13 parallel lines at a $90^{\circ}$ angle. The lines are a uniform depth. The stone was located in a plowed field on a low gravel terrace in the middle of Bennett Creek drainage in Elmore County. This is the closest specimen to the study area. Huntley and Nance (1980) suggest scratched cobbles may be associated with charm or medicine activities. 


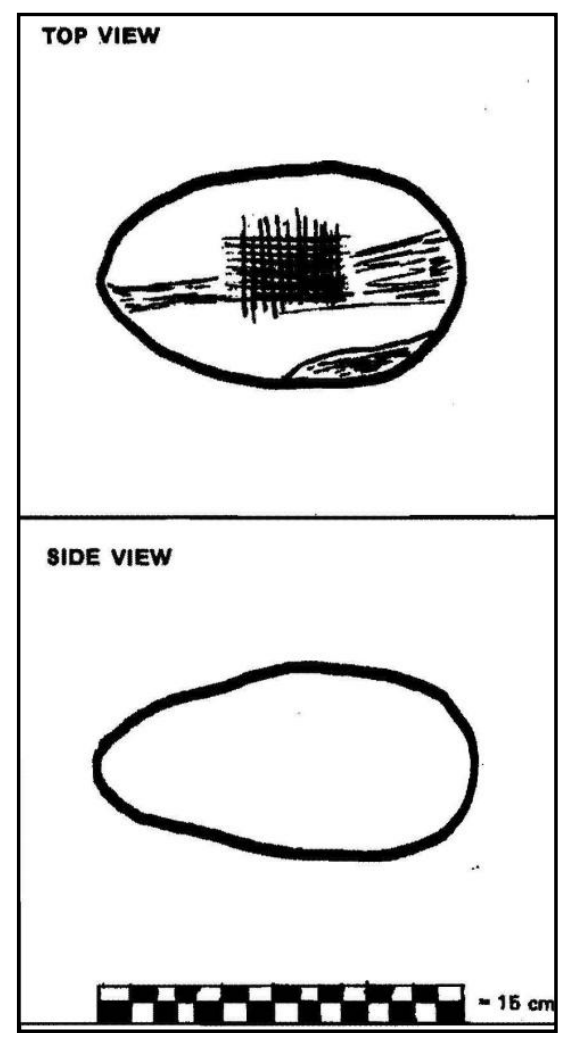

Figure 3.40. Specimen four, (Huntley and Nance 1980).

Nine scratched stones were located at Trapper Cliff (10CA20) in southeast

Idaho (Arkush 2011). All the stones are made from tabular-shaped welded tuff and derived from context dating between 600 to 1,600 A.D. (Arkush 2011). These scratched stones represent a variety of motifs (figure 3.41). One of the stones in the Arkush assemblage (upper left corner of figure 3.41) resembles two of the stones from the Santini (1974) collection from the spring Mountains in southern Nevada (figures 3.55 and 3.48). It is dissimilar to the other scratched stones from Idaho and the scratched petroglyphs in the Bennett Hills. There is a crosshatch design at the bottom of the stone but it is part of a larger composition. The other side of this stone displays a row of triangles with "tufts" emanating from the top. The crosshatch motif in the Bennett Hills and other scratched 
stones from Idaho is usually an independent abstract design, not part of a design composition. Six of the stones display the crosshatch motif, two of the stones display the parallel line motif, and one of the stones displays the plant-like motif (figure 3.41). One of the stones with the parallel line motif also has a serrated edge (upper right corner of figure 3.41).

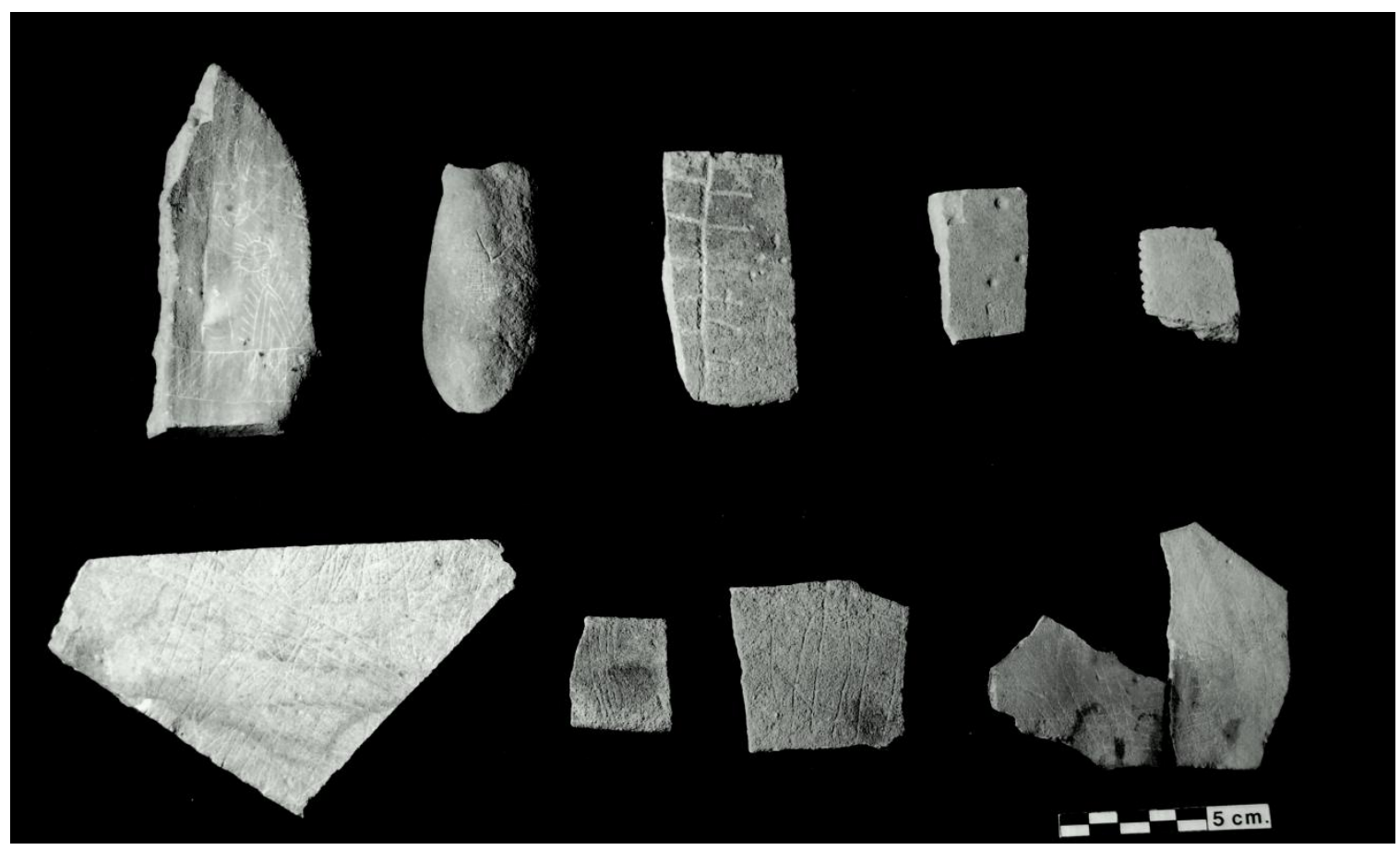

Figure 3.41, Nine scratched stones from Trapper Cliff, southeast Idaho (Arkush 2011).

The 14 scratched stones described in this sample are grouped into three distinct motifs, the crosshatch, the parallel line, and the plant-like motif. The crosshatch is defined as two or more parallel lines bisecting another set of two or more parallel lines. The parallel line motif is defined as two or more lines running parallel to one another. The plant-like motif is a straight line with many straight lines extending off both sides of the line at roughly a $90^{\circ}$ to $45^{\circ}$ angle. These motifs may be elements within a more 
complex petroglyph composition. These three motifs will serve as the basis for comparison with the scratched petroglyph assemblage from the Bennett Hills. Each scratched petroglyph panel in Sample Ones was examined to determine if the crosshatch, parallel line, or plant-like motifs were present or absent (table 3.11).

Table 3.11. Comparative Percentages of the Crosshatch, Parallel Line, and Plant-like Motif.

\begin{tabular}{|c|c|c|c|c|c|c|}
\hline $\begin{array}{c}\text { Scratched } \\
\text { Assemblage }\end{array}$ & $\begin{array}{l}\text { Crosshatch, } \\
\text { percentage }\end{array}$ & $\begin{array}{c}\text { Crosshatch, } \\
\text { n }\end{array}$ & $\begin{array}{c}\text { Parallel } \\
\text { lines, } \\
\text { percentage }\end{array}$ & $\begin{array}{l}\text { Parallel } \\
\text { lines, } \mathbf{n}\end{array}$ & $\begin{array}{l}\text { Plant-like } \\
\text { motif, } \\
\text { percentage }\end{array}$ & $\begin{array}{c}\text { Plant- } \\
\text { like } \\
\text { motif, } \\
\text { n }\end{array}$ \\
\hline $\begin{array}{l}\text { Huntley and } \\
\text { Nance (1989), } \\
\text { Plew (1977), } \\
\text { and Arkush } \\
\text { (2011). }\end{array}$ & $50 \%$ & 7 & $36 \%$ & 5 & $7 \%$ & 1 \\
\hline $\begin{array}{l}\text { Bennett Hills, } \\
\text { Scratched } \\
\text { Petroglyph } \\
\text { Panels, Sample } \\
\text { One } \\
\end{array}$ & $52 \%$ & 36 & $86 \%$ & 59 & $2 \%$ & 5 \\
\hline
\end{tabular}

The crosshatch, parallel line, and plant-like motifs are present in the Huntley and Nance (1980), Plew (1976), and Arkush (2011) scratched stone collections and the scratched petroglyph motif assemblage in the Bennett Hills. Both the scratched stones and the Bennett Hills scratched ptroglyphs are similar in that the motifs are simple and stand alone, except for the Arkush (2011) stone that is like the Santini (1974) collection, where simple motifs are combined into complex compositions. The scratched stones from the Huntley and Nance (1980), Plew (1976), and Arkush (2011) collections are located in closer proximity to the Bennett Hills in comparison to the other collections. These collections may share similar motif assemblages because of their close proximity. 
Unfortunately, the small sample size provides a weak association between scratched stones and petroglyphs in the Bennett Hills.

\section{Assemblage 2, Santini (1974) Collection}

The third assemblage is comprised of scratched stones from two sites in southern Nevada analyzed by Santini (1974). One contains 564 incised stones, the other 203, for a total of 767 incised stones in the collection. Santini has categorized popular design elements within this collection. These design elements will be the basis for comparison with Bennett Hills scratched petroglyphs. Santini (1974) recognized that the design elements may come in any combination, but often have specific rules of placement in relation to one another. These design elements are described in table 3.12 using Santini's (1974) descriptions and terminology. If the motif is present in the Bennett Hills Sample One collection, an example from that collection is provided. Otherwise an example from the Santini (1974) collection is provided.

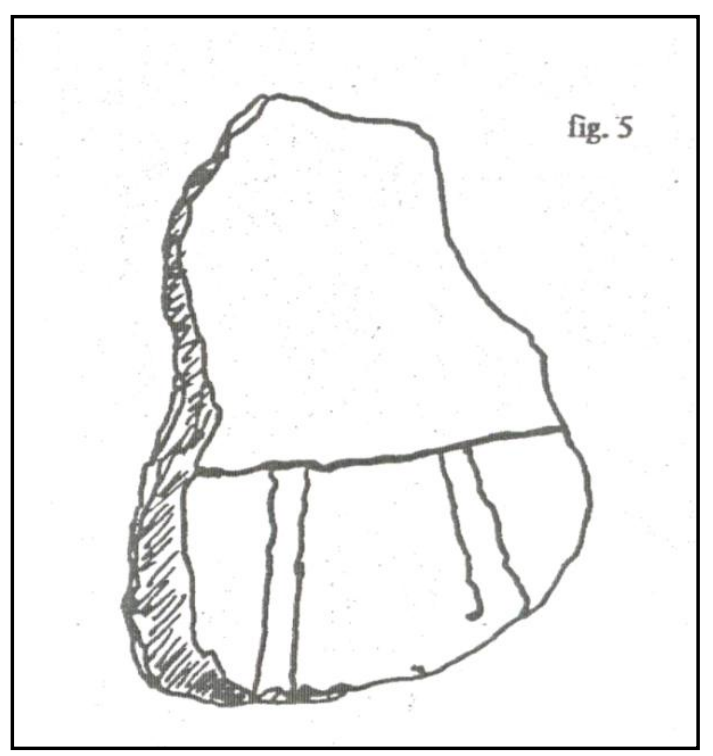

Figure 3.42. Santini collection, motif 1.

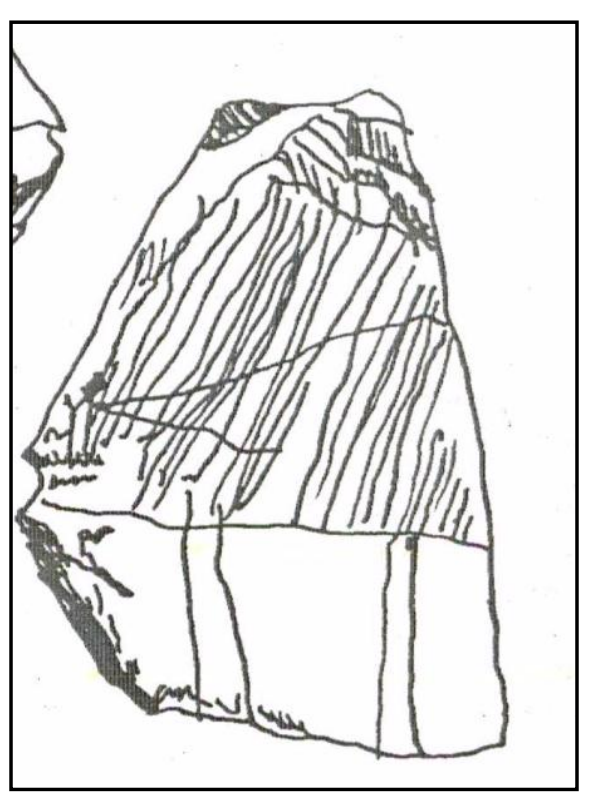

Figure 3.43. Santini collection, motif 2. 


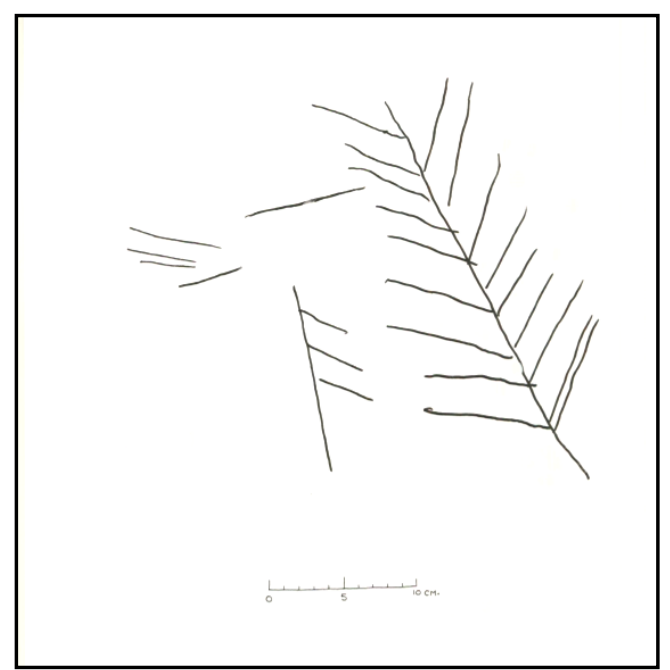

Figure 3.44. 10GG565, panel 12, motif 3.

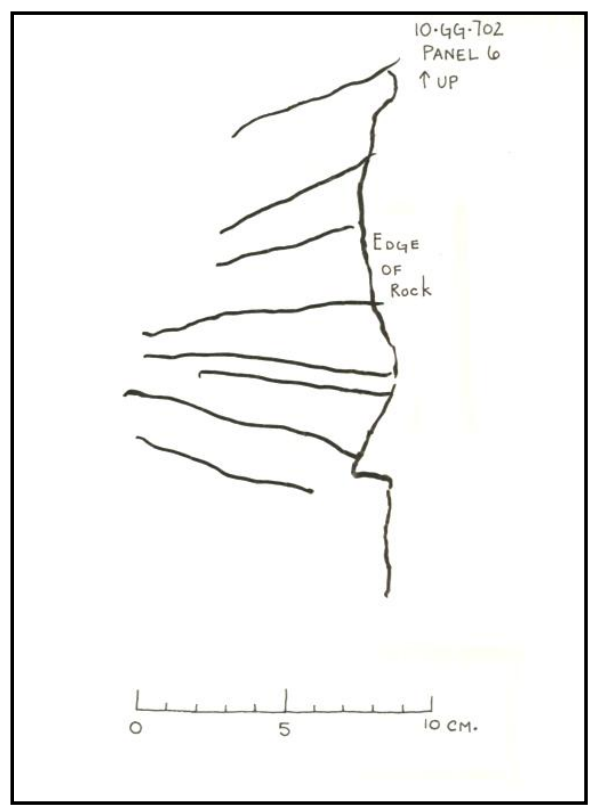

Figure 3.45. 10GG702, panel six, motif 4.

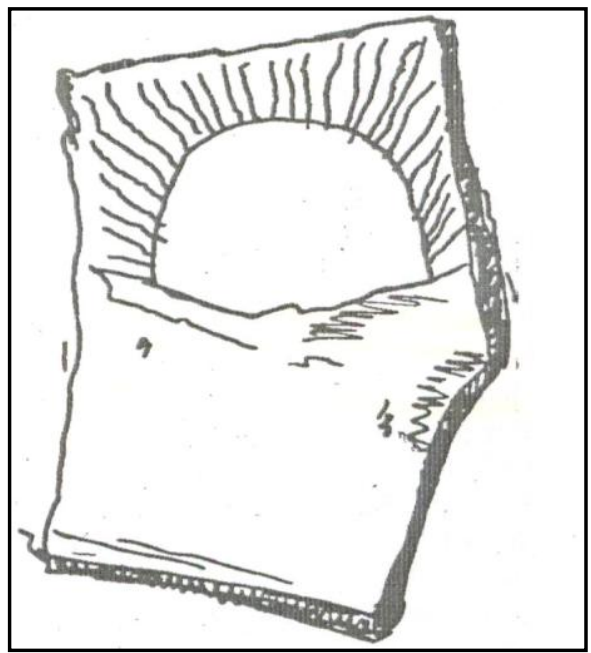

Figure 3.46. Santini collection, motif 5.

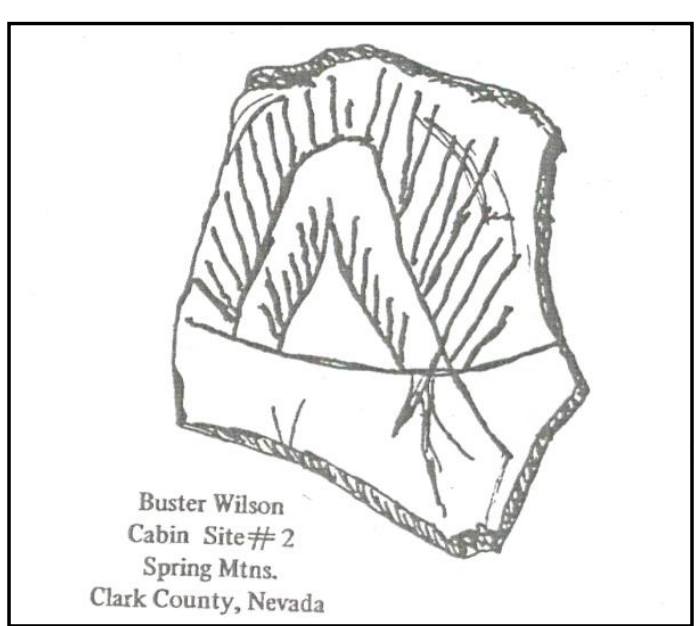

Figure 3.47. Santini collection, motif 6. 82 


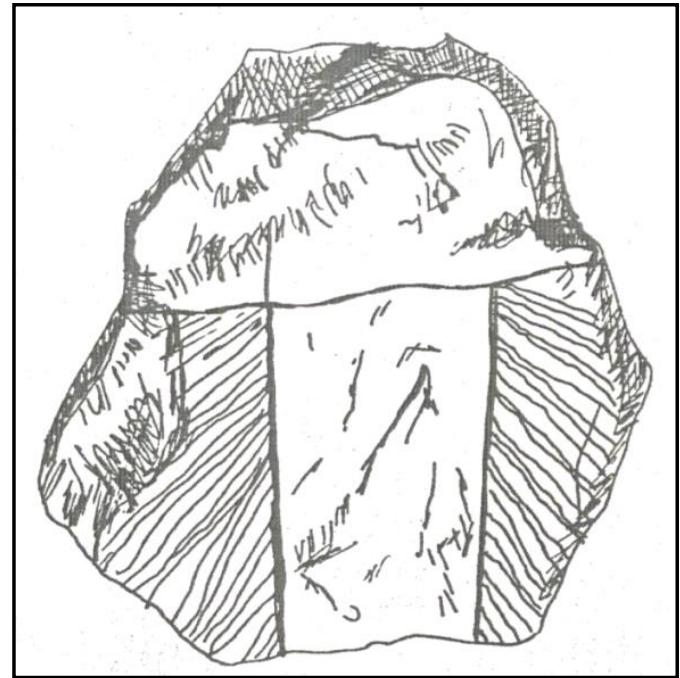

Figure 3.48. Santini collection, motif 7.

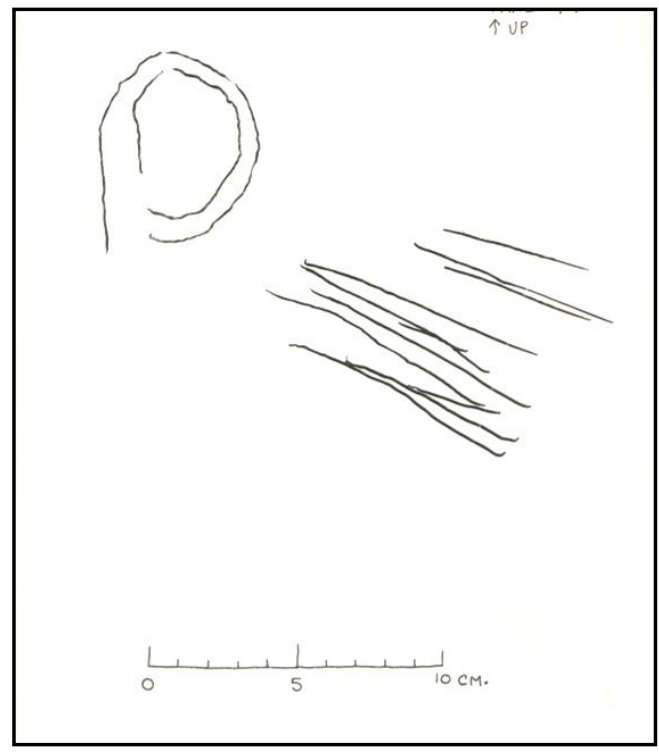

Figure 3.50. 10GG33, panel 9.7, motif 9 .

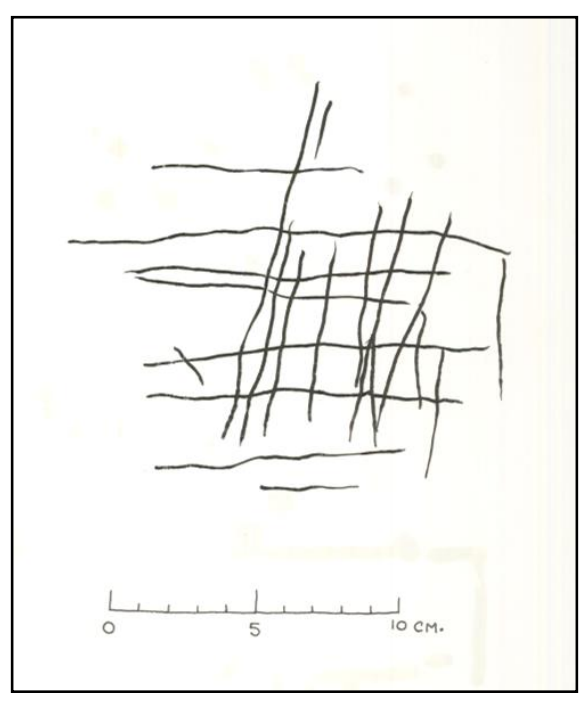

Figure 3.49. 10GG565, panel 1, motif 8 .

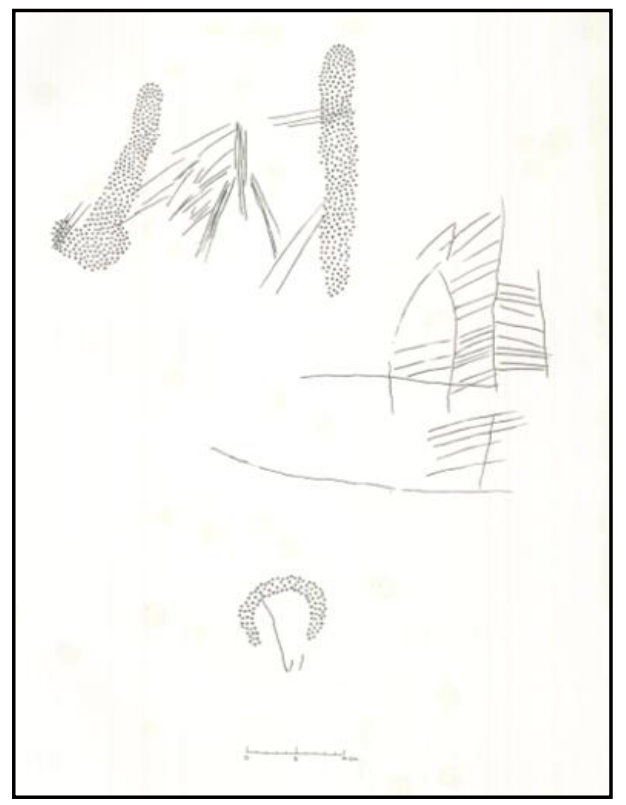

Figure 3.51, 10GG33, panel 15, motif 10. 


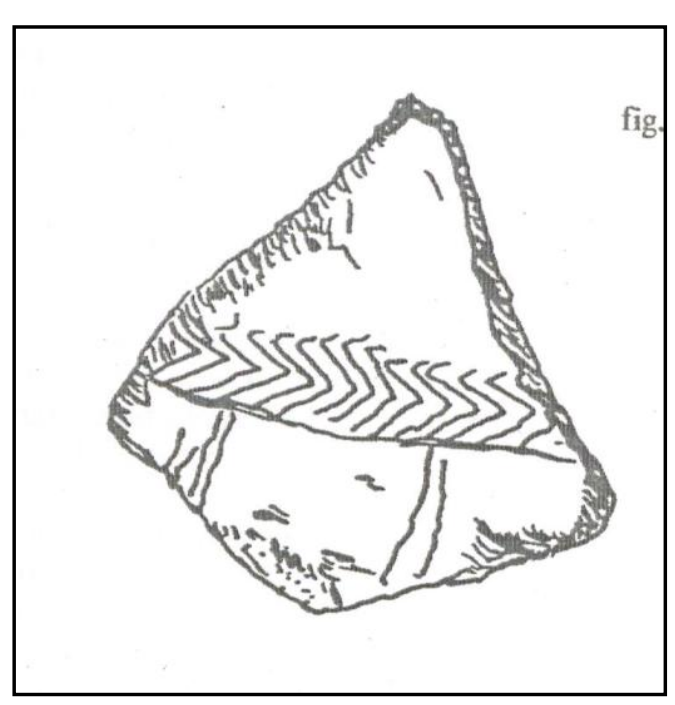

Figure 3.52. Santini collection, motif 11.

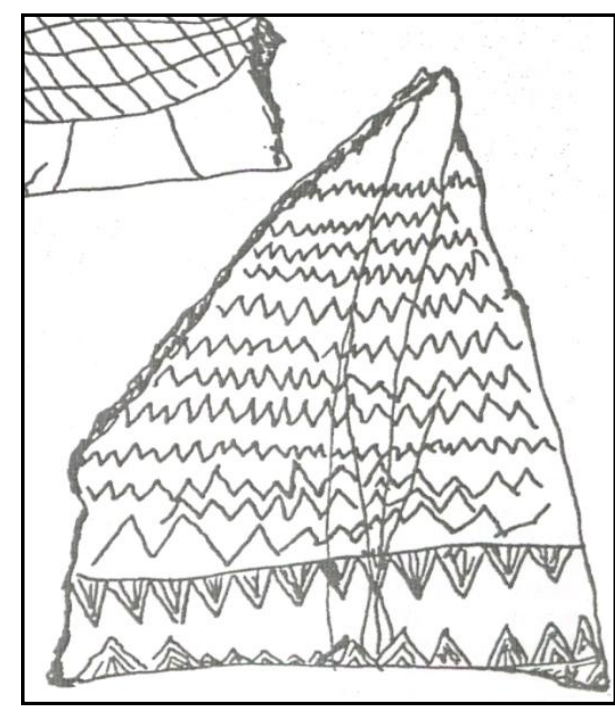

Figure 3.53. Santini collection, motif 12.

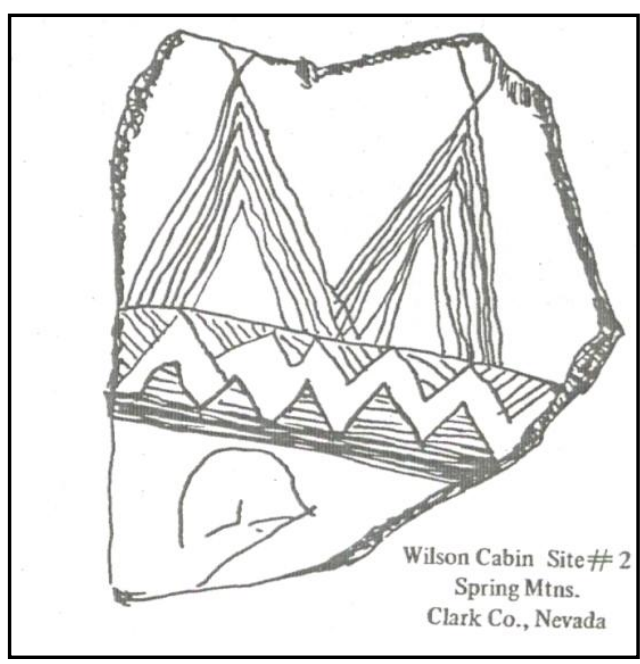

Figure 3.54. Santini collection, motif 13.

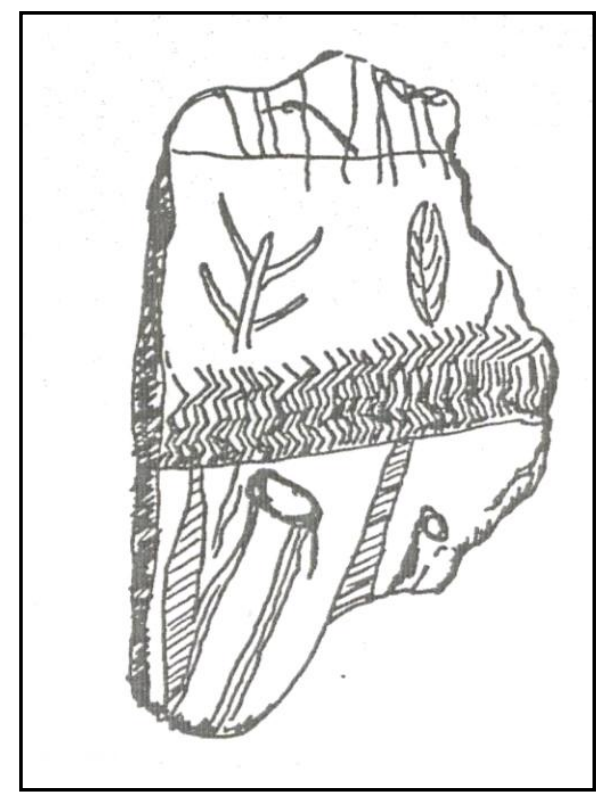

Figure 3.55. Santini collection, motif 14 . 
Table 3.13 lists each Santini design element and the number of each element present in the Bennett Hills, Sample One. There is no quantative data available from the Santini collection.

Only six of 14 design elements represented in the Santini (1974) collection are present in the Bennett Hills scratched petroglyph assemblage. A major dissimilarity between the two motif assemblages is that the Santini (1974) scratched stones are more complex than the scratched petroglyphs from the Bennett Hills. The scratched stones contain many separate design elements that are combined into complex compositions. The design elements in the Bennett Hills occur as independent motifs in a simple composition. Santini (1974) also recognizes that the design elements have specific rules of placement in relation to one another. It does not appear that the Bennett Hills scratched petroglyphs have any patterns of association or placement. Overall it appears that the Santini scratched stone motifs are complex and display distinct patterns while the Bennett Hills Scratched petroglyphs are mostly simple and do not appear to be governed by patterns or rules of composition. The two collections share some design elements, but appear to be more dissimilar than similar. 
Table 3.12, Description of Santini Motifs.

\begin{tabular}{|c|c|c|}
\hline $\begin{array}{l}\text { Motif } \\
\text { No. }\end{array}$ & Description of Motif & $\begin{array}{l}\text { Figure } \\
\text { No. }\end{array}$ \\
\hline Motif 1 & $\begin{array}{l}\text { A parallel line across the face of the stone near the bottom } \\
\text { one-third of the design. The parallel line is often supported } \\
\text { from below by one or more perpendicular lines. }\end{array}$ & $\begin{array}{l}\text { Figure } \\
3.44\end{array}$ \\
\hline Motif 2 & $\begin{array}{l}\text { Several short to long straight lines incised across the top of } \\
\text { the parallel line. }\end{array}$ & $\begin{array}{l}\text { Figure } \\
3.45\end{array}$ \\
\hline Motif 3 & $\begin{array}{l}\text { A short perpendicular line with shorter oblique lines on each } \\
\text { side, best characterized as a "tree-like symbol". }\end{array}$ & $\begin{array}{l}\text { Figure } \\
3.46\end{array}$ \\
\hline Motif 4 & Radiating lines. & $\begin{array}{l}\text { Figure } \\
3.47\end{array}$ \\
\hline Motif 5 & A half or three-quarter circle. & $\begin{array}{l}\text { Figure } \\
3.48 \\
\end{array}$ \\
\hline Motif 6 & $\begin{array}{l}\text { A triangle located above a parallel line, usually expanded to } \\
\text { a triangle within a triangle. }\end{array}$ & $\begin{array}{l}\text { Figure } \\
3.49\end{array}$ \\
\hline Motif 7 & $\begin{array}{l}\text { Parallel lines and legs with feather-like incising on the } \\
\text { outside of the legs. }\end{array}$ & $\begin{array}{l}\text { Figure } \\
3.50\end{array}$ \\
\hline Motif 8 & A checkerboard. & $\begin{array}{l}\text { Figure } \\
3.51 \\
\end{array}$ \\
\hline Motif 9 & A circle within a circle. & $\begin{array}{l}\text { Figure } \\
3.52 \\
\end{array}$ \\
\hline $\begin{array}{l}\text { Motif } \\
10\end{array}$ & A step ladder. & $\begin{array}{l}\text { Figure } \\
3.53\end{array}$ \\
\hline $\begin{array}{l}\text { Motif } \\
11\end{array}$ & A Herringbone. & $\begin{array}{l}\text { Figure } \\
3.54 \\
\end{array}$ \\
\hline $\begin{array}{l}\text { Motif } \\
12\end{array}$ & A zig-zag. & $\begin{array}{l}\text { Figure } \\
3.55 \\
\end{array}$ \\
\hline $\begin{array}{l}\text { Motif } \\
13\end{array}$ & An independent triangle. & \begin{tabular}{|l} 
Figure \\
3.56
\end{tabular} \\
\hline $\begin{array}{l}\text { Motif } \\
14\end{array}$ & Two short lines with a circle on top. & $\begin{array}{l}\text { Figure } \\
3.57 \\
\end{array}$ \\
\hline
\end{tabular}


Table 3.13. Santini Design Elements Present in Bennett Hills Scratched Petroglyph Assemblage.

\begin{tabular}{|r|r|r|}
\hline $\begin{array}{c}\text { Design } \\
\text { Element }\end{array}$ & $\begin{array}{c}\text { Number of Motifs } \\
\text { in Bennett Hills, } \\
\text { Sample 1 }\end{array}$ & $\begin{array}{c}\text { Percentage of the } \\
\text { Bennett Hills } \\
\text { scratched } \\
\text { petroglyph } \\
\text { assemblage }\end{array}$ \\
\hline 1 & 0 & $0 \%$ \\
\hline 2 & 0 & $0 \%$ \\
\hline 3 & 11 & $3 \%$ \\
\hline 4 & 1 & $.3 \%$ \\
\hline 5 & 0 & $0 \%$ \\
\hline 6 & 0 & $0 \%$ \\
\hline 7 & 0 & $0 \%$ \\
\hline 8 & 76 & $23 \%$ \\
\hline 9 & 1 & $.3 \%$ \\
\hline 10 & 5 & $0 \%$ \\
\hline 11 & 0 & $0 \%$ \\
\hline 12 & 0 & $0 \%$ \\
\hline 13 & 0 & $.3 \%$ \\
\hline 14 & 1 & $29 \%$ \\
\hline Total & 95 & \\
\hline
\end{tabular}

\section{Assemblage 3, Thomas (1983) Gatecliff Rockshelter Collection}

The third assemblage is comprised of 428 scratched stones from Gatecliff Shelter in Nevada analyzed by Thomas (1983a). Thomas quantified and categorized a random sample of 165 incised stones using five elements which can be combined in characteristic ways to achieve a great variety of motifs. Thomas (1983) combined these five elements into 48 motif categories (figure 3.58). These categories will be the basis for comparison to determine if there are substantial similarities between the stylistic attributes of scratched petroglyphs in Bennett Hills and a sample of scratched stones from the Gatecliff Shelter (table 3.14). In addition to the scratched motif assemblages, Thomas (1983) identified three techniques employed to scratch stones at Gatecliff Rock shelter. 
The first technique is a simple incision to form a straight line by drawing a sharply pointed instrument across the surface. The second technique is achieved through crushing the surface by rocking or walking a double tipped tool to produce a series of pivot points connected by legs of crushed rock. The third technique results in a series of dots produced by the pivot points of the rocking technique without the connecting lines. These techniques are compared to the techniques used to scratch petroglyphs in the Bennett Hills to identify if similar methods were used to make scratches (table 3.15).

\begin{tabular}{|c|c|c|c|c|c|c|c|c|c|c|c|c|c|c|c|c|c|c|c|c|c|c|c|}
\hline 1 & 2 & 3 & 4 & 5 & 6 & 7 & 8 & 9 & $\begin{array}{l}1 \\
0\end{array}$ & $\begin{array}{l}1 \\
1 \\
\end{array}$ & $\begin{array}{l}1 \\
2 \\
\end{array}$ & $\begin{array}{l}1 \\
3 \\
\end{array}$ & $\begin{array}{l}1 \\
4 \\
\end{array}$ & $\begin{array}{l}1 \\
5 \\
\end{array}$ & $\begin{array}{l}1 \\
6 \\
\end{array}$ & $\begin{array}{l}1 \\
7 \\
\end{array}$ & $\begin{array}{l}1 \\
8 \\
\end{array}$ & $\begin{array}{l}1 \\
9 \\
\end{array}$ & $\begin{array}{l}2 \\
0\end{array}$ & $\begin{array}{l}2 \\
1 \\
\end{array}$ & $\begin{array}{l}2 \\
2 \\
\end{array}$ & $\begin{array}{l}2 \\
3 \\
\end{array}$ & $\begin{array}{l}2 \\
4 \\
\end{array}$ \\
\hline 1 & & Ih & & & & 켸| & 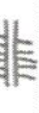 & 병 & 8 & 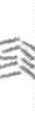 & $\frac{4}{4}$ & $\frac{4}{*}$ & & & & & & & 8 & & & & \\
\hline 2 & 2 & 2 & 2 & 2 & 3 & 3 & 3 & 3 & 3 & $\begin{array}{l}3 \\
5\end{array}$ & 3 & 3 & 3 & $\begin{array}{l}3 \\
0\end{array}$ & 4 & 4 & 4 & 4 & 4 & 4 & 4 & $\begin{array}{l}4 \\
7\end{array}$ & $\begin{array}{l}4 \\
8\end{array}$ \\
\hline 5 & 6 & 7 & 8 & 9 & 0 & 1 & 2 & 3 & 4 & 5 & 6 & 7 & 8 & 9 & 0 & 1 & 2 & 3 & 4 & 5 & 6 & 7 & 8 \\
\hline & & & & & & & & & & & & g) & (9) & & & & r & & & & & & \\
\hline
\end{tabular}

Figure 3.56. Thomas (1983a) motifs. 
Table 3.14. Percentage of Scratched Motifs in the Gatecliff Collection and the Bennett Hills.

\begin{tabular}{|c|c|c|c|c|}
\hline Motif & $\begin{array}{c}\text { Number } \\
\text { of motifs } \\
\text { in the } \\
\text { Bennett } \\
\text { Hills } \\
\end{array}$ & $\begin{array}{c}\text { Percentage, } \\
\text { Bennett } \\
\text { Hills } \\
\end{array}$ & $\begin{array}{c}\text { Number of } \\
\text { motifs in the } \\
\text { Gatecliff } \\
\text { collection }\end{array}$ & $\begin{array}{c}\text { Percentage, } \\
\text { Gatecliff } \\
\text { Collection }\end{array}$ \\
\hline 1 & 3 & $3 \%$ & 20 & $8 \%$ \\
\hline 2 & 7 & $6 \%$ & 13 & $5 \%$ \\
\hline 3 & 10 & $9 \%$ & 5 & $2 \%$ \\
\hline 4 & 15 & $13 \%$ & 60 & $23 \%$ \\
\hline 5 & 2 & $2 \%$ & 20 & $8 \%$ \\
\hline 6 & 6 & $5 \%$ & 6 & $2 \%$ \\
\hline 7 & 0 & $0 \%$ & 3 & $1 \%$ \\
\hline 8 & 0 & $0 \%$ & 2 & $1 \%$ \\
\hline 9 & 2 & $2 \%$ & 14 & $5 \%$ \\
\hline 10 & 2 & $2 \%$ & 2 & $1 \%$ \\
\hline 11 & 0 & $0 \%$ & 3 & $1 \%$ \\
\hline 12 & 35 & $30 \%$ & 19 & $7 \%$ \\
\hline 13 & 5 & $4 \%$ & 3 & $1 \%$ \\
\hline 14 & 0 & $0 \%$ & 22 & $8 \%$ \\
\hline 15 & 0 & $0 \%$ & 3 & $1 \%$ \\
\hline 16 & 0 & $0 \%$ & 1 & $0 \%$ \\
\hline 17 & 3 & $3 \%$ & 1 & $0 \%$ \\
\hline 18 & 0 & $0 \%$ & 5 & $2 \%$ \\
\hline 19 & 1 & $1 \%$ & 6 & $2 \%$ \\
\hline 20 & 0 & $0 \%$ & 3 & $1 \%$ \\
\hline 21 & 0 & $0 \%$ & 3 & $1 \%$ \\
\hline 22 & 0 & $0 \%$ & 1 & $0 \%$ \\
\hline 23 & 0 & $0 \%$ & 1 & $0 \%$ \\
\hline 24 & 0 & $0 \%$ & 2 & $1 \%$ \\
\hline 25 & 0 & $0 \%$ & 1 & $0 \%$ \\
\hline 26 & 0 & $0 \%$ & 2 & $1 \%$ \\
\hline 27 & 0 & $0 \%$ & 1 & $0 \%$ \\
\hline 28 & 0 & $0 \%$ & 1 & $0 \%$ \\
\hline 29 & 0 & $0 \%$ & 1 & $0 \%$ \\
\hline 30 & 0 & $0 \%$ & 1 & $0 \%$ \\
\hline 31 & 0 & $0 \%$ & 1 & $0 \%$ \\
\hline 32 & 0 & $0 \%$ & 1 & $0 \%$ \\
\hline
\end{tabular}


Table $3.14 \quad$ (continued)

\begin{tabular}{|r|r|r|r|r|}
\hline Motif & $\begin{array}{c}\text { Number } \\
\text { of motifs } \\
\text { in the } \\
\text { Bennett } \\
\text { Hills }\end{array}$ & $\begin{array}{c}\text { Percentage, } \\
\text { Bennett } \\
\text { Hills }\end{array}$ & $\begin{array}{c}\text { Number of } \\
\text { motifs in the } \\
\text { Gatecliff } \\
\text { collection }\end{array}$ & $\begin{array}{c}\text { Percentage, } \\
\text { Gatecliff } \\
\text { Collection }\end{array}$ \\
\hline 33 & 0 & $0 \%$ & 1 & $0 \%$ \\
\hline 34 & 0 & $0 \%$ & 2 & $1 \%$ \\
\hline 35 & 0 & $0 \%$ & 1 & $0 \%$ \\
\hline 36 & 0 & $0 \%$ & 1 & $0 \%$ \\
\hline 37 & 0 & $0 \%$ & 1 & $0 \%$ \\
\hline 38 & 1 & $1 \%$ & 1 & $0 \%$ \\
\hline 39 & 0 & $0 \%$ & 1 & $0 \%$ \\
\hline 40 & 1 & $1 \%$ & 2 & $1 \%$ \\
\hline 41 & 0 & $0 \%$ & 1 & $0 \%$ \\
\hline 42 & 0 & $0 \%$ & 3 & $1 \%$ \\
\hline 43 & 0 & $0 \%$ & 1 & $0 \%$ \\
\hline 44 & 0 & $0 \%$ & 1 & $0 \%$ \\
\hline 45 & 24 & $20 \%$ & 12 & $5 \%$ \\
\hline 46 & 0 & $0 \%$ & 2 & $1 \%$ \\
\hline 47 & 0 & $0 \%$ & 2 & $1 \%$ \\
\hline 48 & 0 & $0 \%$ & 1 & $0 \%$ \\
\hline & 117 & $100 \%$ & 260 & $100 \%$ \\
\hline & & & & \\
\hline & 0 & & 1 & 1 \\
\hline
\end{tabular}

Table 3.15. Manufacturing Techniques in the Gatecliff Collection and the Bennett Hills.

\begin{tabular}{|l|l|l|l|l|}
\hline \multicolumn{1}{|c|}{ Technique } & $\begin{array}{c}\text { Number of } \\
\text { motifs, } \\
\text { Bennett Hills }\end{array}$ & $\begin{array}{c}\text { Pennett Hills, } \\
\text { Percentage }\end{array}$ & $\begin{array}{c}\text { Number of } \\
\text { motifs, } \\
\text { Gatecliff }\end{array}$ & $\begin{array}{c}\text { Gatecliff, } \\
\text { Percentage }\end{array}$ \\
\hline $\begin{array}{l}\text { Simple Incision, } \\
\text { straight line } \\
\text { (scratches) }\end{array}$ & 326 & $100 \%$ & - & $71 \%$ \\
\hline Crushing, Zig-zag & 0 & $0 \%$ & - & $19 \%$ \\
\hline Dotted Line & 0 & $0 \%$ & - & $0 \%$ \\
\hline
\end{tabular}

Fifteen of the forty-eight motif categories represented in the Thomas (1983a) collection were present in the Bennett Hills scratched petroglyph assemblage. The 
scratched stones at Gatecliff rock shelter have a larger motif assemblage than that of the Bennett Hills. Like the Santini (1974) collection, the scratched stones from Gatcliff rock shelter are more complex in comparison to the more simple motifs and design compositions of the Bennett Hills. The Gatecliff scratched stone assemblage is similar to the Bennett Hills scratched petroglyphs in that they are all manufactured using the same technique, a simple incision to form a straight line by drawing a sharply pointed instrument across the surface. Like the other collections dissimilarities between these collections may be attributed to regional variability in style.

\section{Quartz}

The last hypothesis postulates an association between scratched rock art and quartz crystals. There is limited evidence that suggests scratched petroglyphs were manufactured with quartz artifacts. Quartz artifacts have been located in close proximity to scratched petroglyphs on the ground surface in Idaho (Murphy 1994) and wedged into cracks in the rock in California (Whitley et al. 1999). The Black Deer site (10OE517) located near the lower Bruneau River in south central Idaho is described by Murphy (1994). Among other pictograph and petroglyph panels he describes "a single circle cross petroglyph carved over a painting and then an intense scratching of the entire painting, this scratching was done presumably with quartz crystals found on the ground immediately below" (Murphy 1994:18). At Indian Writing Waterhole in the Bennett Hills (10GG30) a scratched petroglyph was dated using cation-ratio (CR) and varnish microlamination (VML) methods (Merrell and Dorn 2009). Lead profile-dating and electron dispersive spectroscopy (EDS) were used to determine what if any residue was 
left on the scratched petroglyph (Merrell and Dorn 2009). The residue analysis came back positive for quartz, suggesting the scratched petroglyph was manufactured using a quartz tool (Merrell and Dorn 2009). Quartz serves various religious and shamanic purposes in the western United States (Whitley 1994; Whitley et al. 1999). Some scholars believe scratched petroglyphs were manufactured using quartz because of the religious properties associated with both that material and scratched petroglyphs (Merrell and Dorn 2009; Murphy 1994; Whitley 1994; Whitley et al. 1999). Shamans were known to carry crystals as part of their toolkits (Miller 1983). At this point two case studies are not sufficient to make an association.

All Bennett Hills rock art site records within the study area were reviewed to look for quartz artifacts that could possibly be associated with the manufacture of scratched petroglyphs. Because quartz does not occur naturally in the study area, any quartz artifacts on site would have been transported. Quartz artifacts were recorded on many of the site forms, but were not located in close proximity to scratched petroglyph panels. In addition to the site records review, the ground surface adjacent to the scratched petroglyph panel was examined to locate quartz artifacts. A 10 meter radius around the scratched rock art panel was surveyed using standard pedestrian survey methods. Visibility of the ground surface was excellent around most panels No quartz artifacts were located as a result of survey adjacent to scratched petroglyphs within Sample One. 


\section{Chapter 4, Discussion}

\section{Sample Two}

Data from Sample Two supports the notion that scratched petroglyphs are underrecorded in the Bennett Hills, and possibly other areas throughout the Great Basin. Overall, scratched petroglyphs have not been properly recorded or represented in rock art literature in comparison with other rock art related studies. Scratched rock art can often be very faint, thus less visible than other rock art styles. Scratched petroglyphs do not always penetrate the rock varnish of the host rock and can also accumulate varnish quickly (Christensen 1992). It is often overlooked in the field as a result of bias towards more impressive and elaborate rock art styles. In the past scratched rock art was mistaken for modern graffiti. Because scratched petroglyphs are often faint, less elaborate, and resemble graffiti they were often ignored or misunderstood and as a result have not been sufficiently recorded or researched. Most researchers agree that scratched petroglyphs take a wider variety of forms, occur in more numerous contexts, and are more extensively distributed than initially thought.

\section{Sample One}

\section{Formal Attributes}

The Bennett Hills encompass a limited and distinct assemblage of scratched petroglyph motifs that is dissimilar to petroglyphs manufactured using other techniques. This is significant in that it helps support the idea that scratched petroglyphs are distinct 
not only because scratching is an alternative method to pecking petroglyphs, but also because scratched petroglyphs reflect a unique assemblage of motifs that is different from other petroglyph styles.

Future research should examine possible tools and methods for manufacturing scratched petroglyphs. Experimental archaeology could be employed to replicate scratched petroglyphs. Microscopic analysis could reveal use wear attributes of each tool and technique and then compared to real scratched petroglyphs to help determine how they were made. Residue analysis could also be used to examine the scratched petroglyphs for microscopic residues that may have been left behind by the manufacturing tool. This could help determine if quartz was a common material used to manufacture scratched petroglyphs (as discussed in the fifth hypothesis), or if metal tools were employed, providing a post contact date range for scratched petroglyphs.

\section{Contextual Attributes}

Data was collected to identify contextual associations with scratched petroglyphs. All sites in Sample One are located between 1,188 to 1,676 m asl. The study area is between 762 to 2,255 m asl. According to the Shoshone BLM Field Office Biologist, plants and animals occur in more concentrated numbers in the Bennett Hills between roughly 1,219 and 1,676 m asl, especially during the spring and fall. Evidence also suggests that the environment above $1,767 \mathrm{~m}$ asl would have been relatively inhospitable during much of the year. Snow, strong winds, cold temperatures, and a general lack of resources may have prevented people from lingering above 1,767 $\mathrm{m}$ asl, except during the summer months (Julie Hilty, personal communication 2008). 
This elevation data is consistent with ethnographic data collected in the region. Steward (1938) identified a seasonal round subsistence pattern among the Snake River Shoshoni and the Northern Paiute peoples. This $240 \mathrm{~km}$. round trip took them through the Bennett Hills twice, in the spring and again in the fall. Here chokecherries, sunflowers, yampa, camas, bitterroot, currant, wild rose, elderberry, serviceberry, Great Basin wild rye, and other roots were gathered. Cresswell (2008) identified evidence for plant collection and processing in the Bennett Hills. Testing groundstone for pollen residue she found that grasses, sage, yampa, biscuitroot, and plants from the mint and sunflower family were collected and processed in the Bennett Hills. She identifies that small circular rock features may have served as caches or root collecting pits, particularly when they are associated with groundstone and root gathering areas. She also notes that groundstone is commonly located at sites containing rock art. In addition to plant foods, the region also supplied both small and large game. These vital resources clustered within a specific elevation interval in which scratched petroglyph sites are also found.

Archaeologists (Heizer and Baumhoff 1962; Plew 1996; Thomas 1976) have argued that rock art in the Great Basin is produced in association with the acquisition of resources. Plew (1996) made this association during his investigation of three rock art sites in the South Central Owyhee Uplands. A connection is made between camas meadows, biscuit root fields, and petroglyph elements representing these vital resources. He suggests the petroglyph sites function as a practical marking of resource areas.

Only a few scratched petroglyph motifs in the Bennett Hills can be interpreted as representations of resources (figure 4.1). This motif could possibly represent a feather, 
tree, or plant. Other scratched petroglyphs may be abstracted motifs representing resources.

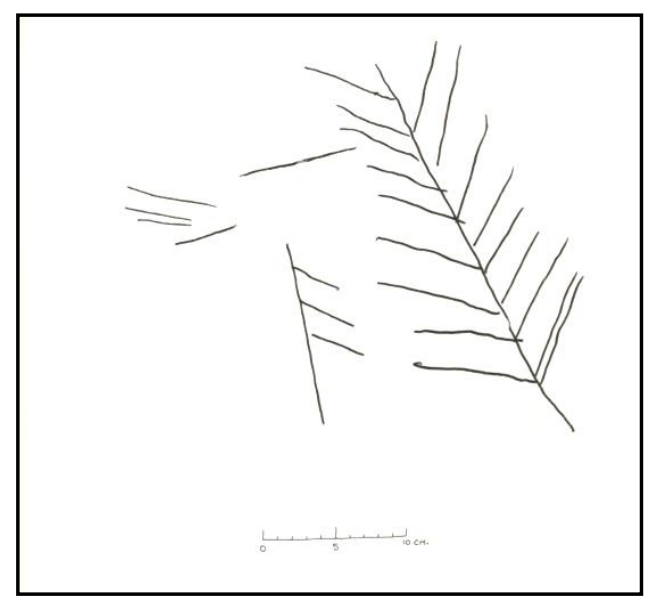

Figure 4.1. 10GG565, panel 12, scratched petroglyph possibly representing a feather, plant, or tree.

A significant percentage of petroglyph sites appear to cluster at water sources.

Eight of the 10 (80 percent) sites in Sample One have water on site. Two of the 10 sites have water within $300 \mathrm{~m}$. This is consistent with data collected at previously recorded petroglyph sites in the Bennett Hills (Hambelton 2008). However, sites without petroglyphs also cluster at water suggesting this phenomenon is not unique to sites containing scratched petroglyphs. The Bennett Hills offered highly localized permanent water sources, surrounded by relatively arid, rocky terrain. As such, the availability of water may have greatly influenced the location of seasonal camps. Valuable resources cluster around water sources, including small and large game and a wide diversity of vital plant life.

Its important to recognize that previously recorded rock art sites were identified through both reconnaissance and intensive surveys. Previous to this research, archaeologists working in the Bennett Hills have identified that sites are located in 
association with water. Using reconnaissance methods surveys are conducted at locations where archaeologists predict sites will be located. One could simply survey lands adjacent to water. Sites may be located in other contexts but if the region were surveyed using only reconnaissance methods then there would be a bias towards sites located near water. Intensive level surveys apply transects at regular intervals in areas that are often associated with projects involving ground disturbance initiating section 106 of the National Historic Preservation Act (NHPA). Intensive methods within a region result in a more broad and random survey sample. The Bennett Hills have been subject to both reconnaissance and intensive level surveys. Site patterning in association with water is not the result of sampling bias.

All ten of the sites in Sample One were located on south facing slopes. The south facing slopes of the Bennett Hills are more gradual than the north facing slopes making the south side easier to traverse. The south facing slopes also have more sun exposure and are warmer than the north facing slopes. Increased sun exposure promotes plant growth which in turn attracts animals. The south facing slopes have more plant and animal resources than the north slopes. Furthermore, the exposed rock surfaces on the north side of the Bennett Hills are different than those of the south facing slopes. The exposed rock on the south facing slopes is abundant, smooth, flat, heavily varnished, and easily accessible. These qualities make an excellent palette for rock art. The exposed rock on the north facing slopes is limited, rough, uneven, and difficult to access. These characteristics do not allow for ideal rock art production. There are likely many factors involved in deciding where rock art is produced, but an adequate rock surface is a 
primary requirement. Satisfactory rocks on which to make rock art are limited in the study area, thus the production of rock art is confined to areas that contain rocks with specific attributes.

Five out of the ten sites in Sample One have rock art located along a rimrock geological feature. The other five sites have rock art located along a U-shaped rimrock with a waterhole. These rhyolite rimrock features are excellent for rock art because they are smooth, flat, accessible, and heavily varnished resulting in petroglyphs that strongly contrast against the dark background. These features are often adjacent to water and provide shade, wind block, and protection from the elements, and possess good acoustic properties.

Rock art sites often occur at an aspect that provides a broad and or aesthetic view of surrounding terrain from and into the site, at springs, and at locations with distinctive geologic landforms. Merrell (2005) recognizes that rock art sites in Idaho are located in relation to specific cultural and physical landscapes. Exceptional viewsheds, unique geologic and environmental features, and events occurring at specific locations imbue landscapes with cultural significance (Merrell 2005). Rock art is often located within these landscapes. This is consistent with the landscape symbolism model (Whitley et al. 2004). This model, drawn from ethnographies and oral narratives, examines the distribution of supernatural power on the landscape and how that effects the interaction between Native Americans and their physical surroundings. Rock art and other significant objects occur at specific locations as an expression of the power at that location (Whitley et al. 2004; David 2009). Recognizing the aesthetic and supernatural 
qualities of landscapes is subjective and cannot be measured. Ethnography can help identify landscapes with cultural or sacred qualities but this data is not currently available in the Bennett Hills. Its important to consider that scratched petroglyphs may be located in association with culturally significant landscapes.

All the sites in Sample One are adjacent to open lithic scatters. In addition to rock art, these sites contain artifacts and features representing small seasonal field camps. These sites not only inspired the manufacture of rock art, but were also locations in which hunting, gathering, and camping occurred. Many of the sites are too dense and large to be produced by a small family group during a single short term occupation, but rather were occupied repeatedly. Scratched rock art occurs at sites with projectile point styles ranging from the Early Archaic to the contact era. There is no way of knowing if these projectile points were deposited at the same time scratched petroglyphs were manufactured, but it does provide a rough estimate of when these sites were occupied.

Three out of 10 sites in Sample One contain stacked rock features. Stacked rock features have been associated with personal quests for spirit power and esoteric knowledge in the Colombia Plateau (Caldwell and Carlson 1954; Ray 1942; Spier and Sapir 1930) and the northern Great Basin (Ray 1963; Minor et al. 1979; Aikens 1993; Miller 1983; Daehnke and Raymond 2008). Loubser and Whitley (1999) recognize that stacked rock features and rock art occur alongside one another at Lava Beds National Monument in northern California. Daehnke and Raymond (2008) also recognize an association between stacked rock features and petroglyphs at Petroglyph Lake in south central Oregon. Daehnke and Raymond (2008) recognize that the water, commanding 
views, petroglyphs, and a concentration of subsistence resources create a powerful landscape in which peoples engage in subsistence, social, and ritual activities. There appears to be a similar phenomena happening in the Bennett Hills. There may be significance in these features co-occurring at these sites. The evidence for a possible association between stacked rock features and petroglyphs in the Bennett Hills is compelling, but preliminary, requiring more research.

It is possible that the production of rock art occurred alongside other activities in view of the peoples currently occupying the site. This is consistent with other rock art sites in the Great Basin (Cannon and Ricks 2007; Leach 1988; Stoney 1990; Ritter 1994). This context is similar to rock art in the Warner Valley and surrounding uplands of south central Oregon. Cannon and Ricks (2007) recognize that rock art in this region was created in public, in a participatory context, as part of daily life, for a sizable group of people, at locations where resource gathering and processing occurred. Ritter (1994) also identified a similar association at two scratched rock art sites in Nevada. He found that scratched rock art occurs near hunting and gathering locals, springs, and trails.

These studies hypothesize that the production of rock art and other subsistence related activities were occurring contemporaneously and possibly in association with one another. It is important not to assume that because activities occured in the same space that they are interrelated. Perhaps the production of rock art was confined to certain hours or days in which the individual or group were abstaining from other activities. There are not sufficient data to determine if the rock art was produced while other activities were occurring and possibly in association with those activities. The production of scratched 
petroglyphs could represent an independent event occurring at different times of the year, certain days, or a specific time of day at the same location where other activities were occurring. It is also possible that only slight spatial removal from other activities would have been sufficient to produce rock art in an independent context. An avenue for future research would be to gain a stronger understanding of how the production of rock art is organized in time and space in relation to other activities combining archaeological and ethnographic methods.

\section{Hypothesis Testing}

\section{Associations between Scratched and Pecked Petroglyphs}

There are various hypotheses that deal with the interaction between scratched and pecked petroglyph styles. Data was collected to identify how many scratched petroglyphs are associated with pecked petroglyph styles, whether scratched petroglyphs are associated with specific pecked motifs, and if scratched and pecked petroglyphs are consistently manufactured in a specific temporal order.

Scratched petroglyphs occur in independent and isolated contexts but the majority is associated with other pecked petroglyph styles. Many scratched petroglyphs are intentionally associated with pecked styles but the purpose of this relationship remains obscure. Scratched petroglyphs do not commonly occur with any one pecked petroglyph motif. It is clear that scratched petroglyphs are always later and superimposed over earlier pecked petroglyphs. Scratched petroglyphs also serve some purpose in isolated contexts. Scratched petroglyphs alone are significant and need to be considered independent of other pecked motifs. 
Data was collected to test three hypotheses concerning the intention of association between scratched and pecked petroglyphs. Researchers have identified that scratched petroglyphs serve to obliterate earlier pecked petroglyphs, enhance earlier pecked petroglyphs, and serve as a sketch that would be pecked later. None of the three hypotheses concerning the intention of association between scratched and pecked petroglyphs can sufficiently describe the range of patterns and associations found in the Bennett Hills scratched petroglyph assemblage.

The first hypothesis suggest superimposition of scratched petroglyphs over earlier pecked petroglyphs serves to obliterate earlier rock art Heizer and Baumhoff (1962) and Bettinger and Baumhoff (1982). Superimposition appears to be a significant association between scratched and pecked petroglyphs. Data collected concerning temporal order suggests scratched petroglyphs are later than and always superimposed over earlier pecked petroglyph styles, consistent with this hypothesis. However, there is no evidence suggesting scratched petroglyphs were superimposed over earlier pecked petroglyphs to obliterate earlier rock art (Heizer and Baumhoff 1962, Bettinger and Baumhoff 1982). Superimposition is significant but the function remains unexplained. This data is consistent with Ritter's (1994) examination of scratched petroglyphs in Nevada. He also found that scratched petroglyphs occur both independently and associated with pecked petroglyphs, but not for the purpose of obliteration.

The second hypothesis recognizes that scratched petroglyphs are often added to pecked petroglyphs as an embellishment. All of the scratched petroglyphs in Sample One are later and superimposed over earlier pecked petroglyph styles, consistent with this 
hypothesis. Nine (22 percent) of the associated scratched petroglyphs panels in Sample One display characteristics in support of this hypothesis, but all associated scratched petroglyphs in cannot be explained with this hypothesis. Its possible that these scratches were added after pecked petroglyphs were manufactured to alter the original purpose of the design either in a positive or negative manner (Hedges 1973).There is evidence that rock art sites were and continue to be revisited to renew and obtain power from these culturally significant sites (Whitley 1992). Adding scratches to a pecked petroglyph may have served to instill older images with additional or renewed power (Schaafsma 1985). Its difficult to test the intention of adding scratches to an earlier petroglyph. These data may help support Hedges (1973) hypothesis, but it cannot be used to determine why scratched petroglyphs were added to earlier pecked petroglyphs. It appears that many rock art sites in the Bennett Hills were revisited numerous times and that rock art accumulated at a site over a long period of time. It is possible that earlier petroglyphs were altered as the sites were revisited over time.

The third hypothesis posits that Scratched petroglyphs are a sketch or pre-form to plan a design that would be pecked or abraded later (Turner 1971; Pilles 1975). Of the associated scratched petroglyph panels there are only three ( 8 percent) that display characteristics of pre-form or tracing, providing very little support for this hypothesis in the Bennett Hills. This hypothesis requires that scratched petroglyphs were manufactured before pecked petroglyphs. Of these three panels there are no instances where the scratches are superimposed over pecked motifs or vice versa, thus no data is available concerning the temporal order of scratching and pecking. However, in all instances of 
superimposition in Sample One scratched petroglyphs are later and superimposed over earlier pecked petroglyphs. Data concerning the temporal order of scratched and pecked petroglyphs are not consistent with this hypothesis. Heizer and Baumhoff (1962) also recognized the possibility for scratched petroglyphs to serve as rough pattern for pecked petroglyphs, but dismiss the idea suggesting that scratched petroglyphs usually appear to be later than pecked petroglyphs.

\section{Scratched Stones}

This thesis also examines hypotheses suggesting associations between scratched rock art and other archaeological phenomena. Parallels between portable scratched stones and scratched rock art on non-portable rock surfaces (Pilling 1957; Santini 1974; Pilles 1975; Moriorty 1982; Christensen 1992, Hedges 1989, Thomas 1983) were examined. It is possible that if scratched petroglyphs and stones were found to be stylistically similar then one could assume that they share similar social functions (Pilling 1957). Data was collected in the Bennett Hills to determine if scratched petroglyphs in that area are comparable to three assemblages of scratched stones from the Great Basin.

Scratched petroglyphs in the Bennett Hills share a few similarities with scratched stones from the Great Basin, but are overall more dissimilar. There are some distinct motifs represented in both contexts. For example, the crosshatch is well represented in both the Bennett Hills and the scratched stone collections. It also appears that a similar technique was employed to manufacture both the stones and petroglyphs. 
Dissimilarities between the Bennett Hills scratched petroglyphs and scratched stones could be related to regional variability in style. The Santini and Gatecliff rockshelter collections are located in the southern Great Basin. The Bennett Hills are at the northern extent of the Great Basin. The Huntley and Nance, Plew, and Arkush collections are located in closer proximity to the Bennett Hills and share more similarities than those collections located farther to the south. It would be interesting to examine if scratched petroglyphs occurring in closer proximity to the Gatecliff rock shelter are more similar to the motifs on the scratched stones at Gatecliff. It is possible that there is considerable regional variation in scratched motifs and that scratched stones and scratched petroglyphs occurring in the same area would be more similar than those farther from one another. Many scholars have noted possible similarities between scratched stones and scratched petroglyphs, but there is no general consensus that these phenomena are related or what implications that relation would have. Overall, there are far more dissimilarities than similarities. It would not be accurate to conclude that scratched petroglyphs and stones are stylistically similar and share similar social functions.

\section{Quartz}

There is limited evidence suggesting that scratched petroglyphs were manufactured with quartz. The site records review and survey conducted at the ten sites in Sample One failed to identify quartz artifacts associated with scratched petroglyph panels. It is possible that the tools used to make petroglyphs were carried with the artist rather than disposed of at the petroglyph panel. If quartz was treasured for religious or shamanic purposes (Whitley 1994; Whitley et al. 1999) it may not have been disposed of 
purposefully or haphazardly. If quartz artifacts were not purposefully left behind at the petroglyphs they were used to create, then a survey of the site records and the immediate area surrounding petroglyphs would not be an effective method to identify an association between scratched petroglyphs and quartz. Residue analysis at scratched petroglyphs (Merrell and Dorn 2009) may be a more effective method to identify if scratched petroglyphs are made with quartz tools. 


\section{Chapter 5, Conclusion}

An analysis of the formal qualities of scratched petroglyphs was applied to quantify the extent and characterize the motif assemblage of scratched petroglyphs in the Bennett Hills. This analysis revealed that there are more scratched petroglyphs in the Bennett Hills than records and literature currently indicate. Few site records indicate the presence of scratched petroglyphs, although as a result of this analysis it appears to be ubiquitous in the Bennett Hills. Scratched petroglyphs have not been properly recorded or represented in rock art literature in comparison with other rock art related studies. It is possible that scratched petroglyphs are under recorded in other locals as well, and that further investigations may reveal not only the presence, but the dominance of scratched petroglyphs at rock art sites throughout the Great Basin. Having an accurate understanding of the types and quantities of rock art styles within a site and region is a critical component of a holistic model for rock art research.

The under recordation of scratched petroglyphs in the Bennett Hills, and possibly in other areas, raises an issue concerning land management decisions. Most rock art sites in the Bennett Hills are identified and recorded as part of cultural resource management (CRM) surveys. These surveys are designed to identify and record cultural resources, evaluate their significance, and assess the impact of an undertaking on those resources. It appears that past CRM surveys have overlooked scratched petroglyphs, as they are rarely recorded in site records or reports. This research has established that scratched 
petroglyphs in the Bennett Hills are extensive and have significant data potential. Identifying scratched petroglyphs as part of CRM surveys may alter how these properties are evaluated and in turn how they are managed.

The formal analysis revealed that the Bennett Hills encompass a limited and distinct assemblage of scratched petroglyph motifs that is dissimilar to petroglyphs manufactured using other techniques. Scratched petroglyphs reflect a unique manufacturing technique and distinctive assemblage of motifs that is different from pecked petroglyph motifs. This data implies that scratched petroglyphs may serve a unique function that is different from and independent of pecked petroglyphs. This bolsters the need for scratched petroglyphs to be recorded and analyzed in detail, rather than continuing to be bypassed for more interesting and elaborate rock art styles.

Contextual data was gathered as part of this research to examine patterns of proximity to artifacts, features, environments, and landscapes. Scratched petroglyph sites are located at specific elevation intervals, in close proximity to water, on south facing slopes, and on rimrock style geological features. The contextual analysis also revealed that scratched petroglyphs often occur within archaeological sites in close proximity to other artifacts and features. There are no instances where scratched petroglyphs occur independently of other archaeological materials. This study identified a limited association between stacked rock features and scratched petroglyphs. This association has potential significance and is worthy of future research. The contextual analysis suggests rock art may have been produced in a public context in close proximity to subsistence related activities, perhaps in association with resource gathering events. There are not 
sufficient data to determine if the rock art was produced while other activities were occurring and possibly in association with those activities. The production of scratched petroglyphs could represent an independent event occurring at different times of the year, certain days, or a specific time of day at the same location where other activities were occurring. An avenue for future research would be to gain a stronger understanding of how the production of rock art is organized in time and space in relation to other activities combining archaeological and ethnographic methods.

There are various hypotheses that deal with the interaction between scratched and pecked petroglyph styles. Scratched petroglyphs occur in independent and isolated contexts but the majority is associated with other pecked petroglyph styles. Scratched petroglyphs do not commonly occur with any one abraded or pecked petroglyph motif. In Sample One all of the scratched petroglyphs are later and superimposed over earlier pecked petroglyphs.

Data was collected to test three hypotheses concerning the intention of association between scratched and pecked petroglyphs. It does not appear that scratched petroglyphs serve to obliterate earlier pecked petroglyphs or function as a sketch that would be pecked later. There is evidence that some scratched petroglyphs enhance earlier pecked petroglyphs. Future research should concentrate on further testing this hypothesis using data from scratched petroglyph sites throughout the Great Basin in combination with ethnographic data. However, none of the hypotheses concerning the intention of association between scratched and pecked petroglyphs can sufficiently describe the range of patterns and associations found in the Bennett Hills scratched petroglyph assemblage. 
These results are consistent with other scratched rock art studies. Christensen (1992) recognizes that scratched petroglyphs in the Great Basin display multiple attributes including obliteration, embellishment, pre-forming, and the manufacture of the images in and of themselves and that the purpose of manufacture is not specific to a region, culture, or site, but that multiple patterns co-occur in multiple contexts.

This thesis also examines hypotheses suggesting associations between scratched rock art and other archaeological phenomena. The association between scratched petroglyphs and scratched stones is deserving of further research. Overall, there are far more dissimilarities than similarities but, there are some distinct motifs and techniques represented in both contexts. It is possible that there is considerable regional variation in scratched motifs and that scratched stones and scratched petroglyphs occurring in the same area would be more similar than those farther from one another. The methodology used to test this hypothesis may have been flawed in assuming that if scratched stones are similar to scratched petroglyphs then the motif assemblage they share should be homogenous throughout the Great Basin. Comparing a large sample of scratched petroglyphs and stones located in close proximity to one another could be a productive avenue for future research.

It may also be too soon to dismiss the association between scratched petroglyphs and quartz. The methodology employed to test this hypothesis was based on the assumption that if scratched petroglyphs were manufactured using quartz then quartz artifacts could be located in association with scratched petroglyphs. If quartz was treasured for religious or shamanic purposes (Whitley 1994; Whitley et al. 1999) it may 
not have been disposed of purposefully or haphazardly. If quartz artifacts were not purposefully left behind at the petroglyphs they were used to create, then a survey of the site records and the immediate area surrounding petroglyphs would not be an effective method to identify an association between scratched petroglyphs and quartz. Residue and use wear analysis may be a more effective method to identify if scratched petroglyphs are made with quartz tools.

Living Native American peoples representing tribes with past and present associations with the study area have not been recently consulted concerning their knowledge of the petroglyphs in the Bennett Hills. This level of research is beyond the scope of this work, but could be extremely useful and long past due. A more in-depth ethnographic review including site visits and interviews with tribal members having knowledge of the Bennett Hills could have great data potential. It would also provide an opportunity for Native Americans to have a say in research concerning their culture and heritage and allow them to collaboratively manage rock art sites in the Bennett Hills.

With the exception of the methodologies used to test scratched stones and quartz, the methodologies employed to collect data concerning the other hypotheses, qualitative and quantative data, and contextual associations were successful.

Although many ambiguities and questions remain, significant insights are gained in understanding scratched petroglyphs in the Bennett Hills. Some ambiguities in the comprehension of rock art imagery will always have to be tolerated. Out of these uncertainties new thoughts and ideas will arise (Derida 1982). Rock art research is important in that it can reveal insights into prehistoric ideologies that other archaeological 
phenomena cannot. The examination of scratched petroglyphs in the Bennett Hills provides a unique insight into the minds of the makers of these petroglyphs, contributing valuable data our knowledge of the prehistoric peoples of the Bennett Hills. 


\section{Bibliography}

Aikens, Melvin C.

1993 Archaeology of Oregon. U.S. Department of the Interior, Bureau of Land Management, Portland.

Arkush, Brooke

2011 The Archaeology of Trapper Cliff Shelter: A Late Holocene Residential Base Camp in Cassia County, Southcentral Idaho. Manuscript on file, Department of Anthropology and Sociology, Weber State University, Ogden, Utah.

Bard, Lorna

2000 Mount Bennett: Historical Cattle Ranches and Points of Interest in the Bennett Hills. Personal publication.

2005 The Town of Bliss and a Tour of Clover Creek. Personal publication.

Bettinger, Robert L., and Martin A. Baumhoff

1982 The Numic Spread: Great Basin Cultures in Competition. American Antiquity 47(3):485-503. 
Blackburn, Thomas

1977 Biophysical Aspects of Chumash Rock Art. Journal of California Anthropology 4:88-94.

Bradley, Richard

1997 Rock Art and the Prehistory of Atlantic Europe: Signing the Land. Routledge, London.

Busby, C., R. Flemming, R. Hayes, and K. Nissen

1978 The Manufacture of Petroglyphs: Additional Replicative Experiments from the Western Great Basin. In Four Rock Art Studies, edited by W. Clewlow, pp. 89-108, Ballena Press, Albuquerque.

Caldwell, Warren W. and Roy L. Carlson 1954 Further Documentation of "Stone Piling" During the Plateau Vision Quest. American Anthropology 56(3):441-442. 
Cannon, William J., and Mary F. Ricks

1986 The Lake County Oregon Rock Art Inventory: Implications for Prehistoric Settlement and Land Use Patterns. In Contributions to the Archaeology of Oregon 1983-1986, edited by Kenneth M. Ames, pp. 1-22. Department of Anthropology and University Foundation Occasional Papers, Portland State University and the Association of Oregon Archaeologists, Salem.

1999. Rock Art as an Indicator of Site Age in the Northern Great Basin. Paper presented at the $64^{\text {th }}$ annual meeting of the Society for American Archaeology. Chicago, Illinois.

2007 Settlement and Rock Art in the Warner Valley Area, Oregon. In Great Basin Rock Art: Archaeological Perspectives, edited by Angus R. Quinlan, pp. 107-125. University of Nevada Press, Reno.

Castleton, Kenneth B., and David B. Madsen

1981 The Distribution of Rock Art Elements and Styles in Utah. Journal of California and Great Basin Anthropology 3(2):163-175.

Chippindale, Christopher, and George Nash 2004 The Figured Landscapes of Rock Art: Looking at Pictures in Place. Cambridge University Press, Cambridge. 
Christensen, Don

1992 Scratched Glyphs in Arizona: A Reevaluation. Rock Art Papers Vol. 9, No. 28. San Diego Museum of Man, California.

Cinadr, Thomas J.

1976 Mount Bennett Hills Project: Analysis of Archaeological Resources.

Archaeological Reports of the Idaho State University Museum of Natural History, Pocatello.

Clewlow, C. William, Jr.

1978 Prehistoric Rock Art. In Plateau, edited by Robert F. Heizer, pp. 619-625.

Handbook of North American Indians, Vol. 15, William C. Strurtevant, general editor, Smithsonian Institution, Washington, D.C.

Coe, Joffre L.

1964 The Formative Cultures of the Carolina Piedmont. Transactions of the American Philosophical Society 54(5). Philadelphia.

Conkey, Margaret. W. and Cristine Hastorf 1990 Introduction. In The Uses of Style in Archaeology, edited by Margaret W. Conkey and Cristine Hastorf. Cambridge University Press, Cambridge. 
Cresswell, Lisa

2008 Pollen and Starch Analysis of Prehistoric Groundstone Tools from Several Bennett Hills Sites, Idaho. Paper presented at the $31^{\text {st }}$ Biennial Great Basin Anthropological Conference. Portland, Oregon.

Curtis, John S.

1990 Determination of Cultural Boundaries and Affiliations by an Analysis of Petroglyphs. Paper presented at the 22nd annual meeting of the Great Basin Anthropological Conference, Reno.

Daehnke, Jon and Anan Raymond 2008 The Archaeology of Petroglyph Lake: Landscapes, Publics Past, and Publics Present. United States Fish and Wildlife Service, Cultural Resource Series No. 14.

David, Robert

2009 The Archaeology of Myth: Rock Art, Ritual Objects, and Mythical Landscapes of the Klamath Basin. Archaeologies: Journal of World Archaeological Congress 6(2): 372-400.

Davis, E. L., D. True, and G. Sterud 1965 Notes on Two Sites in Eastern California: Unusual Finds. UCLA Archaeological Survey Annual Reports 7:323-332. 
Davis, William B.

1939 The Recent Mammals of Idaho. The Caxton Printers, Ltd., Caldwell.

Decarlo, Matthew M.

2008 Preliminary Results of the Calf Creek Oasis (10GG122) Test Excavations,

Bennett Hills, Idaho. Paper presented at the $31^{\text {st }}$ biennial Great Basin Anthropological Conference. Portland, Oregon.

Derrida, Jacques

1982 Margins of Philosophy. University of Chicago Press, Chicago.

Dewdney, Jeffery S.

1979 Verbal Versus Visual Approaches to Rock Art Research. In Heritage Record, edited by D. Lundy, pp. 325-339. British Colombia Provincial Museum, British Colombia.

Douglas, William

1973 Lonely Lives Under the Big Sky. Natural History 82(3):28-39. 
Fowler, Catherine S., and Lawerence E. Dawson

1986 Ethnographic Basketry. In Great Basin, edited by W.L. D'Azevedo, pp. 705-737. Handbook of North American Indians, Vol. 2, William C. Strurtevant, general editor, Smithsonian Institution, Washington D.C.

Gebhard, Davis S.

1963 Review of Prehistoric Rock Art of Nevada and Eastern California, by Robert F. Heizer and Martin A. Baumhoff. American Antiquity 28(4):563-564.

Georgetta, Clel 1965 Sheep in Nevada. Nevada Historical Society Quarterly 8(2):15-38.

Hambelton, Karla

2008 Distribution of Rock Art Sites in the Bennett Hills, Idaho. Paper presented at the $31^{\text {st }}$ Biennial Great Basin Anthropological Conference, Portland.

Hedges, Ken

1973 Rock Art in Southern California. Pacific Coast Archaeology Society Quarterly 9(4):1-28.

1982 Great Basin Rock Art Styles: A Revisionist View. American Indian Rock Art 7

(8):205-211 
1989 Sketches and Scratches. Rock Art Papers Vol. 6, No. 24. San Diego Museum of Man, California.

Heizer, Robert F. and Baumhoff, Martin A.

1962 Prehistoric Rock Art of Nevada and Eastern California. University of California Press, Berkeley.

Huntley, James L. and W. Nance

1980 More Incised Cobbles. Idaho Archaeologist 3(2):8-9.

Jones, B. M., Jr.

1986 Preliminary Investigations into a Southern California Summer Solstice Site.

Rock Art Papers Vol. 3, No. 20. San Diego Museum of Man, California.

Keyser, James D.

1975 A Shoshonean Origin for the plains Shield Baring Warrior Motif. Plains Anthropologist 20:207-215.

Keyser, James D. and Michael A. Klassen

2001 Plains Indian Rock Art. University of Washington Press, Seattle. 
Keyser, James D. and Michael W. Taylor

2002 The Blade Cuts Two Ways: Using Ethnographic Analogy to Interpret the Colombia Plateau Scratched Style. Paper presented at the $29^{\text {th }}$ Annual American Rock Art Research Association Conference, Dubois, Wyoming.

Keyser, James D., George Poetschat, and Michael W. Taylor 2006 Talking With the Past: The Ethnograpgy of Rock Art. Oregon Archaeological Society publication no. 16 .

Klimowicz, Janis

1988 Incised Stones from the Great Basin: A Comparison of Sites. Nevada Archaeologist 6(2):29-39.

Leach, Melinda

1988 Subsistence Intensification and Settlement Change Among Prehistoric Hunters And Gatherers of the Northwestern Great Basin. Ph.D. Dissertation, Department of Anthropology, University of California.

Lee, Georgia and William D. Hyder

1991 Prehistoric Rock Art as an Indicator of Cultural Interaction and Tribal Boundaries in South Central California. Journal of California and Great Basin Anthropology 13(1):15-28. 
Leen, Daniel G.

1988 An Inventory of Hells Canyon Rock Art. Enterprise Oregon: U.S. Forest Service, Hells Canyon National Recreation Area.

Loubser, Johannes H. N., and David S. Whitley 1999 Recording Eight Places with Rock Imagery, Lava Beds National Monument, Northern California, Vol. 1. New South Associates Technical Report 604, on file at National Park Service, Redwood National Park, Areata, Califomia.

Malde H. E., Powers, H. A., and Marshall, C. H., 1963 Reconnaissance geologic map of west-central Snake River Plain, Idaho: U.S. Geol. Survey Misc. Geol. Inv. Map I-373.

Merrell, Carolynne L. 2000 Black Canyon Wilderness Survey Area Rock Art Inventory. Cost Share Agreement No. DDP990013. Report on file with Snake River District BLM. 2002 Fifteen Pictograph Sites Located Between Skull Canyon and Goddard Canyon in Birch Creek Valley. Cost Share Agreement No. DAA000103. Report on file with Idaho Falls District BLM.

2003 Rock Art within the Blue Dome Campground Containing Bison (10CL10) and Veratic (10CL3) Rock Shelters. Cost Share Agreement No. DAA010110. Report on file with Snake River District, BLM. 
2004 Pictographs from the Middle Fork of the Salmon River. Report on file with the Salmon Challis National Forest, Salmon, Idaho.

2005 Location, Location, Location: Rock Art as Sacred Geography. In Making Marks:

Graduate Studies in Rock Art Research at the New Millenniun. Edited by Jennifer K.K Huang and Elizabeth V. Cully, pp. 183-196. American Rock Art Research Association Occasional Paper No. 5.

2007 Indian Writing Waterhole Petroglyphs. A Report on File with the Shoshone District, Bureau of Land Management, Shoshone, Idaho.

Merrell, Carolynne and Julie Rodman

2005 Site Report for Brand Rock. Report on file with the Shoshone District BLM, Idaho.

Merrell, Carolynne L. and Ronald I. Dorn 2009 Indian Writing Waterhole and Tom's Spring: Two Central Idaho Petroglyph Sites in the Great Basin Tradition. American Indian Rock Art 35:203-217.

Miller, Jay

1983 Basin Religion and Theology: A Comparative Study of Power (Puah). Journal of California and Great Basin Anthropology 5:66-86. 
Minor, Rick, Stephen Dow Beckham, and Kathryn Anne Toepel

1979 Cultural Resource Overview of the BLM Lakeview District, South-Central

Oregon. Report on file at the Department of Anthropology, University of Oregon, Eugene.

Molyneaux, Brian Leigh

1977 Formalism and Contextualism: A Historiography of Rock Art Research in the New World. Master's thesis, Department of Anthropology, Trent University, Peterborough, Ontario.

Monteleone, Sue Ann 1998 Great Basin Rock Art: Numic Tradition or Multicultural Diversity? American Indian Rock Art 22:19-28.

Moriarty, James R.

1982 Ritual Plaques from Southern California. Masterkey 56(3):85-94.

Murphey, Kelly

1994 Rock Art of the Eastern Bruneau Desert and Adjacent Segment of the Middle Snake River Country. Idaho Archaeologist 17(1):3-28. 
Pavesic, Max G. and William Studebaker

1993 Backtracking: Ancient Art of Southern Idaho. Idaho Museum of Natural History, Pocatello.

Pilles, Peter J., Jr.

1975 Petroglyphs of the Little Colorado River Valley. Arizona. Paper presented at the 1974 Rock Art Symposium, Bloomfield, New Mexico.

Pilling, Arnold R.

1957 An Incised Pebble from Lassen County, California. University of California Archaeological Survey Reports 38(51):6.

Plew, Mark

1976 A Note on a Notched Stone Cobble from Southwestern Idaho. Idaho Archaeologist 1(3):9-12.

1996 Distribution of Rock Art Elements and Styles at Three Localities in South Central Owyhee Uplands. Idaho Archaeologist 19(1):3-10

Quinlan, Angus R. and Alanah Woody

2003 Marks of Distinction: Rock Art and Ethnic Identification in the Great Basin. American Antiquity 68(2):372-390. 
Ray, Verne F.

1942 Culture Element Distributions: 12 Plateau. Anthropological Records 8:2.

Berkeley.

1963 Primitive Pragmatists: The Modoc Indians of Northern California. University of Washington Press, Seattle.

Ricks, Mary

1995 A Survey and Analysis of Prehistoric Rock Art of the Warner Valley Region, Lake County, Oregon. Master's thesis, Department of Anthropology, Portland State University.

Ritter, Eric W.

1994 Scratched Rock Art Complexes in the Desert West: Symbols for Socio-Religious Communication. In New Light on Old Art: Recent Advances in Hunter Gatherer Rock Art Research, edited by David .S Whitley and Lawerence L. Loendorf. Institute of Archaeology Monograph 36, University of California, Los Angeles.

Santini, James D.

1974 A Preliminary Report on the Analysis of Incised Stones from Southern Nevada. Nevada Archaeologist 2(1):4-15. 
Schaafsma, Polly

1971 The Rock Art of Utah. Papers of the Peabody Museum of American Archaeology and Ethnology No. 65. Harvard University, Cambridge.

1985 Form, Content, and Function: Theory and Method in North American Rock Art Studies. In Advances in Archaeological Methods and Theory, edited by M.B.

Schiffer, pp. 237-277.Academic Press, New York.

1986 Rock Art. In Great Basin, edited by Warren L. D’Azevedo, pp. 215-226.

Handbook of North American Indians, Vol. William C. Strurtevant, general editor, Smithsonian Institution, Washington D.C.

Schuster, Carl

1968 Incised Stones from Nevada and Elsewhere. The Nevada Archaeological Survey Reporter 2(5):4-23.

Simonis, D.

1986 Scratched Style Petroglyphs near Kingman, Arizona. Paper presented at the 13th Annual American Rock Art Research Association Symposium, Flagstaff.

Smith, Chuck

2000 Map of the Great Basin Culture Area. Electronic document, http://www.saa.org/Portals/0/SAA/Publications/StyleGuide/styleguide.pdf, accessed November 29, 2011. 
Spier, Leslie and Edward Sapir

1930 Wishram Ethnography. University of Washington Publications in Anthropology

\section{3:3. Seattle.}

Steward, Julian H.

1938 Basin-Plateau Aboriginal Sociopolitical Groups. Bureau of American Ethonology Bulletin No. 120.

Stoney, Stephen

1994 Rock Art in the Great Basin: The Scratched Style Mystery Reexamined: Is it Illusion or Reality. Pacific Coast Archaeological Society Quarterly 30(4):34-54.

Taylor, Michael W. and James D. Keyser

2003 Colombia Plateau Scratched Style: A Preliminary Interpretation. American Indian Rock Art 29:11-20.

Thomas, Trudy

1979 Petroglyph Distribution and the Hunting Hypothesis in the Central Great Basin. Tebiwa 18(2):65-74. 
Thomas, David

1983a Material Culture of Gatecliff Shelter: Incised Stones. In The Archaeology of Monitor Valley, edited by David Hurst Thomas, Anthropological Papers pp. American Museum of Natural History, New York. 1983b The Visual Symbolism of Gatecliff Shelter. In The Archaeology of Monitor Valley 2: Gatecliff Shelter, edited by Davis Hurst Thomas, Anthropological Papers, pp. 332-352. American Museum of Natural History, New York.

Touhy, Donald R.

1963 Archaeological Survey in Southwestern Idaho and Northern Nevada.

Nevada State Museum Anthropological Papers, No. 8, Nevada State University.

Turner, Christy G.

1971 Petroglyphs of the Glen Canyon Region. Museum of Northern Arizona Bulletin Vol. 38, No. 4.

Walker, Deward E., Jr.

1971 American Indians of Idaho. Anthropological Monographs of the University of Idaho No. 2. University of Idaho, Moscow. 
Waller, Steve

2011 Acoustic Mapping of Rock Art Soundscapes: Depicting Echoes Visibly. Paper presented at the $38^{\text {th }}$ Annual American Rock Art Research Association Conference, Idaho Falls, Idaho.

White, Thain and Carling Malouf

1963 Again, Those Stone Piles. Archaeology in Montana 5(1):19-21.

Whitley, David S., Baird J. Bennett, and R.G. Tuck

1984 The Use of Relative Repatination in the Chronological Ordering of Petroglyph Assemblages. Journal of New World Archaeology 4(3):19-25.

Whitley, David S., J. Loubser, and D.T. Hann 2004 Friends in Low Places: Rock Art and Landscape Symbolism on the Modoc Plateau. In The Figure Landscape of Rock Art: Looking at Pictures in Place. Edited by Christopher Chippendale and George Nash. Cambridge University Press, New York.

Whitley David S., Ronald I. Dorn, Joseph M. Simon, Robert Rechman, and Tamara K. Whitley

1999 Sally's Rockshelter and the Archaeology of the Vision Quest. Cambridge Archaeological Journal 9(2):221-247. 
Whitley, David S.

1988 Bears and Baskets: Shamanism in California Rock Art. In The State of the Art: Advances in World Rock Art Research, edited by T.A. Downson, pp. 34-42.

Archaeology Department, University of the Witwaterstrand, Johannesburg, South Africa.

1992 Shamanism and Rock Art in Far Western North America. Cambridge Archaeological Journal 2:89-113.

1994 By the Hunter, for the Gatherer: Art, Social Relations, and Subsistence Change in the Prehistoric Great Basin. World Archaeology 25:354-377. 1998 Meaning and Metaphor in the Coso Petroglyphs. Understanding Great Basin Rock Art. In Coso Rock Art: A New Perspecitve, edited by E. Younkin, pp. 109174. Maturango Museum, Ridgecrest. 2005 Introduction to Rock Art Research. Left Coast Press, Walnut Creek. 
Appendix A

Scratched Petroglyph Tracings 


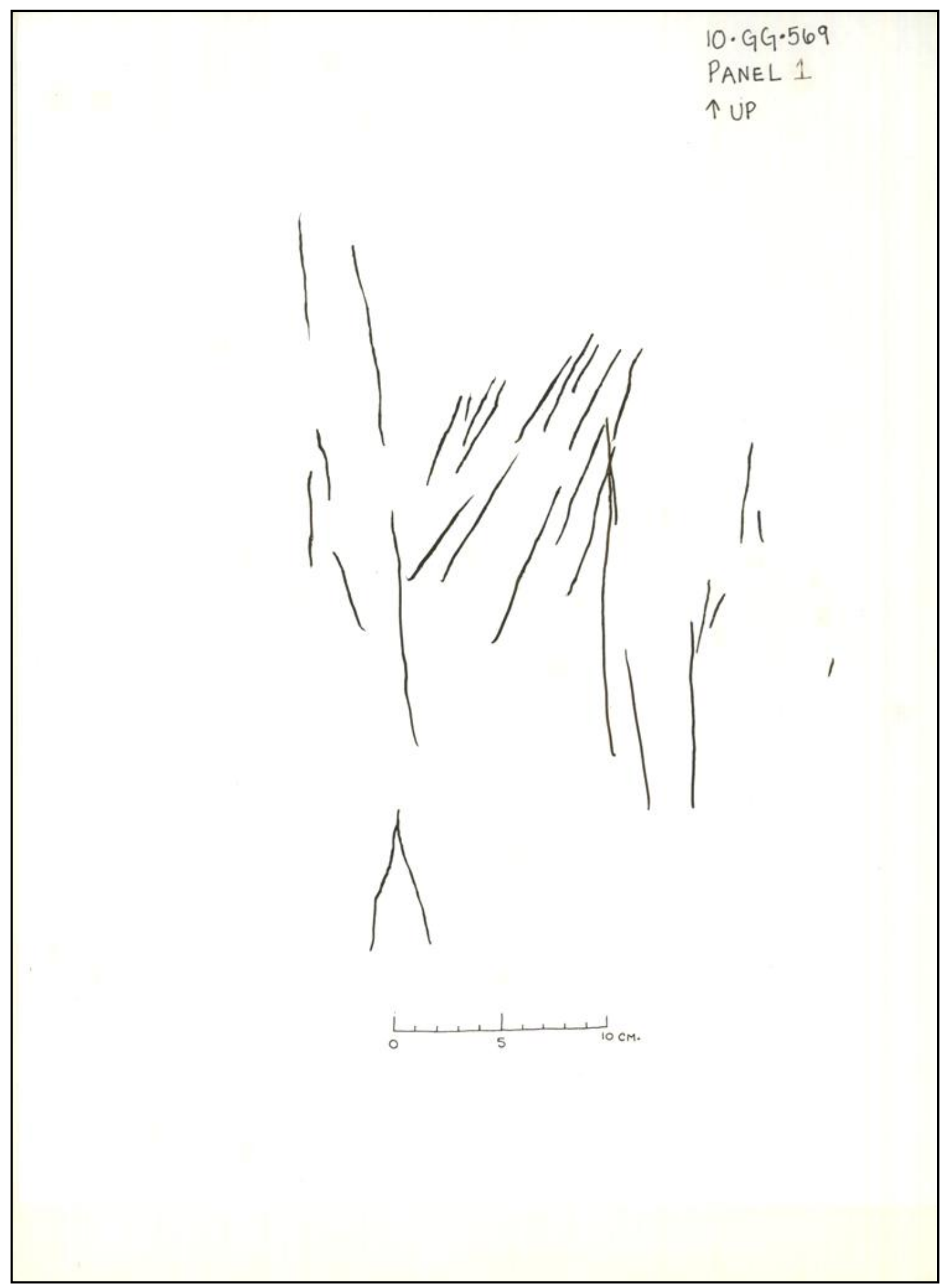

Figure A.1. 10GG569, panel 1. 


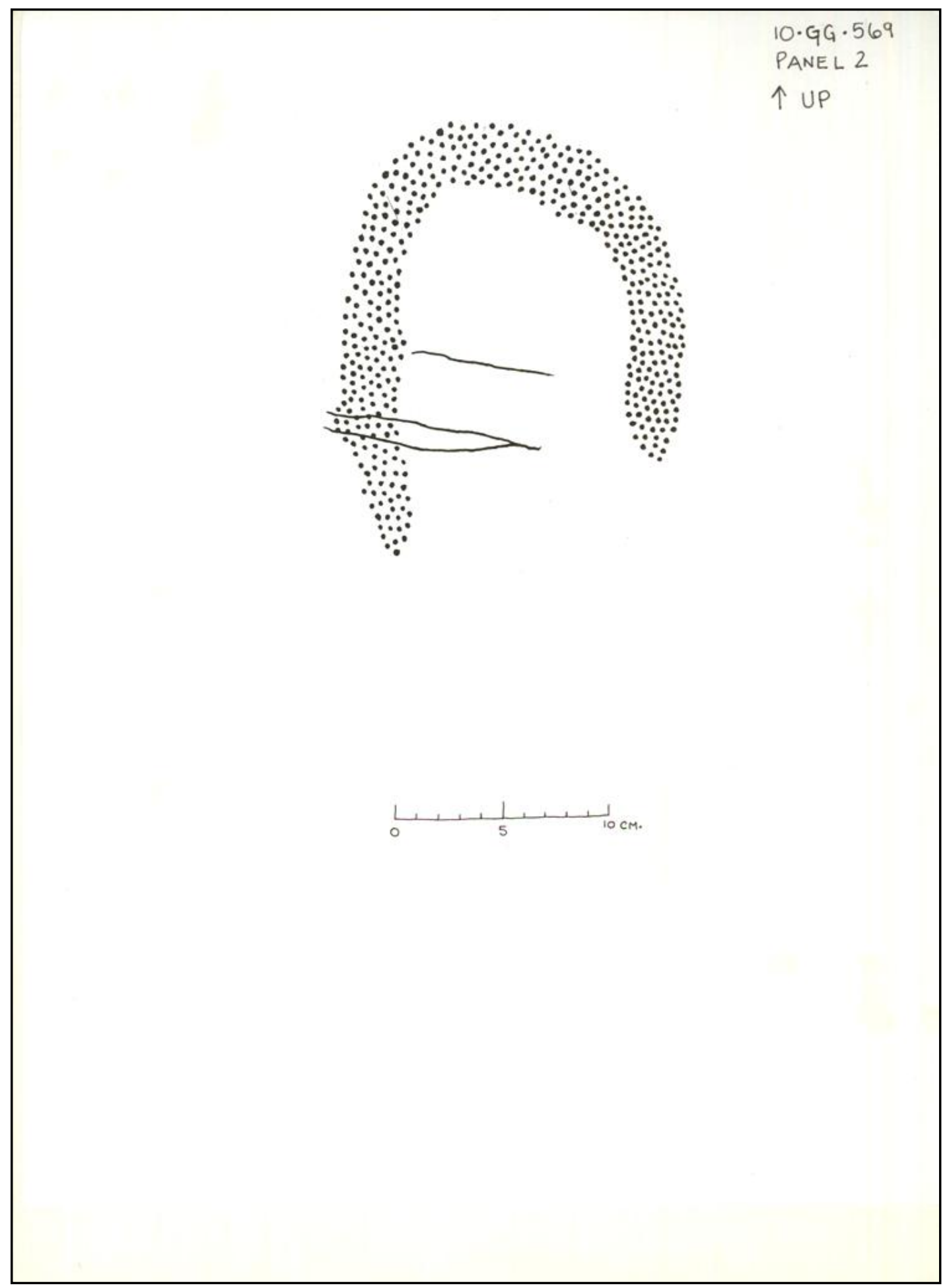

Figure A.2. 10GG569, panel 2. 


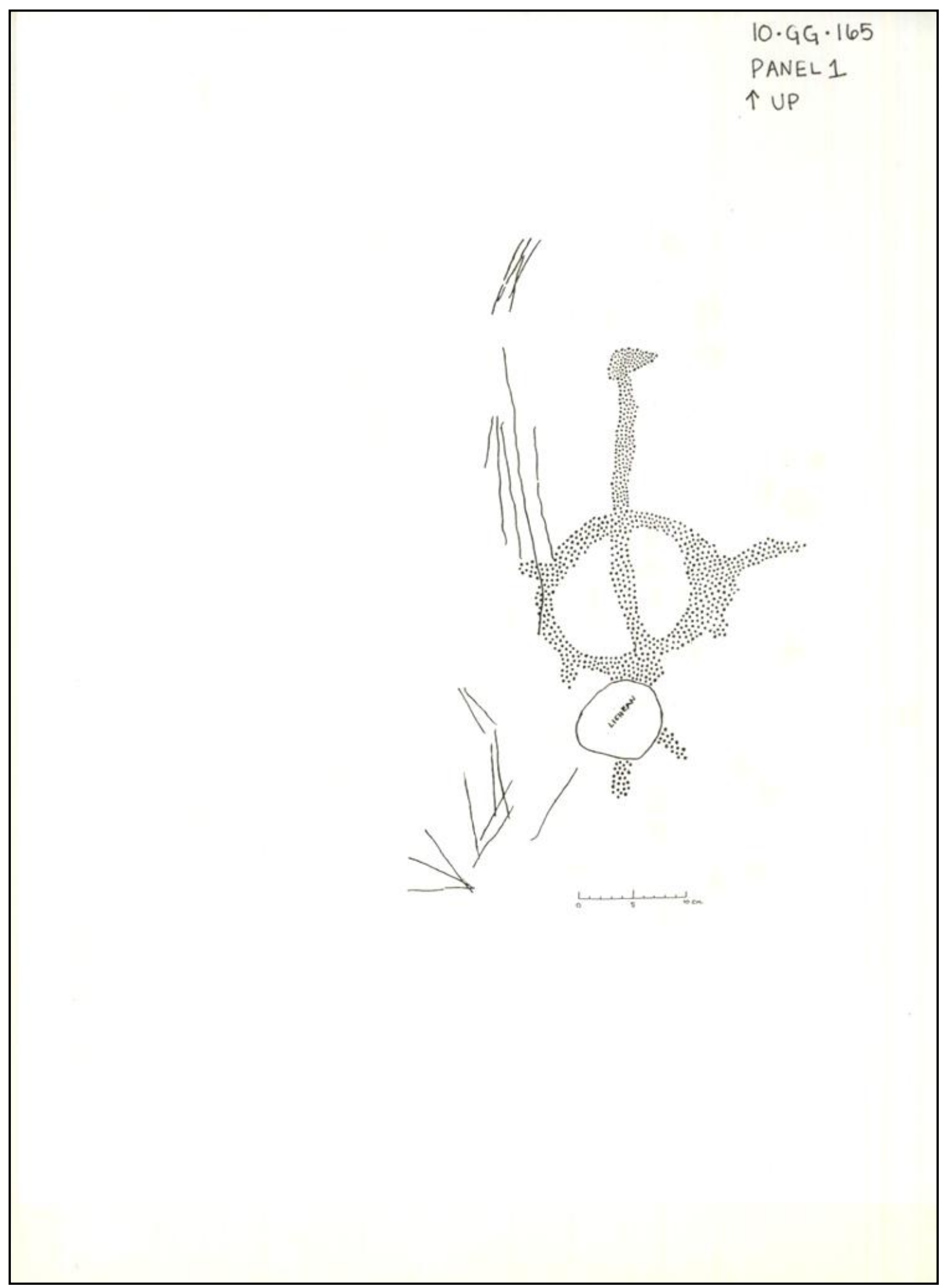

Figure A.3. 10GG165, panel 1. 


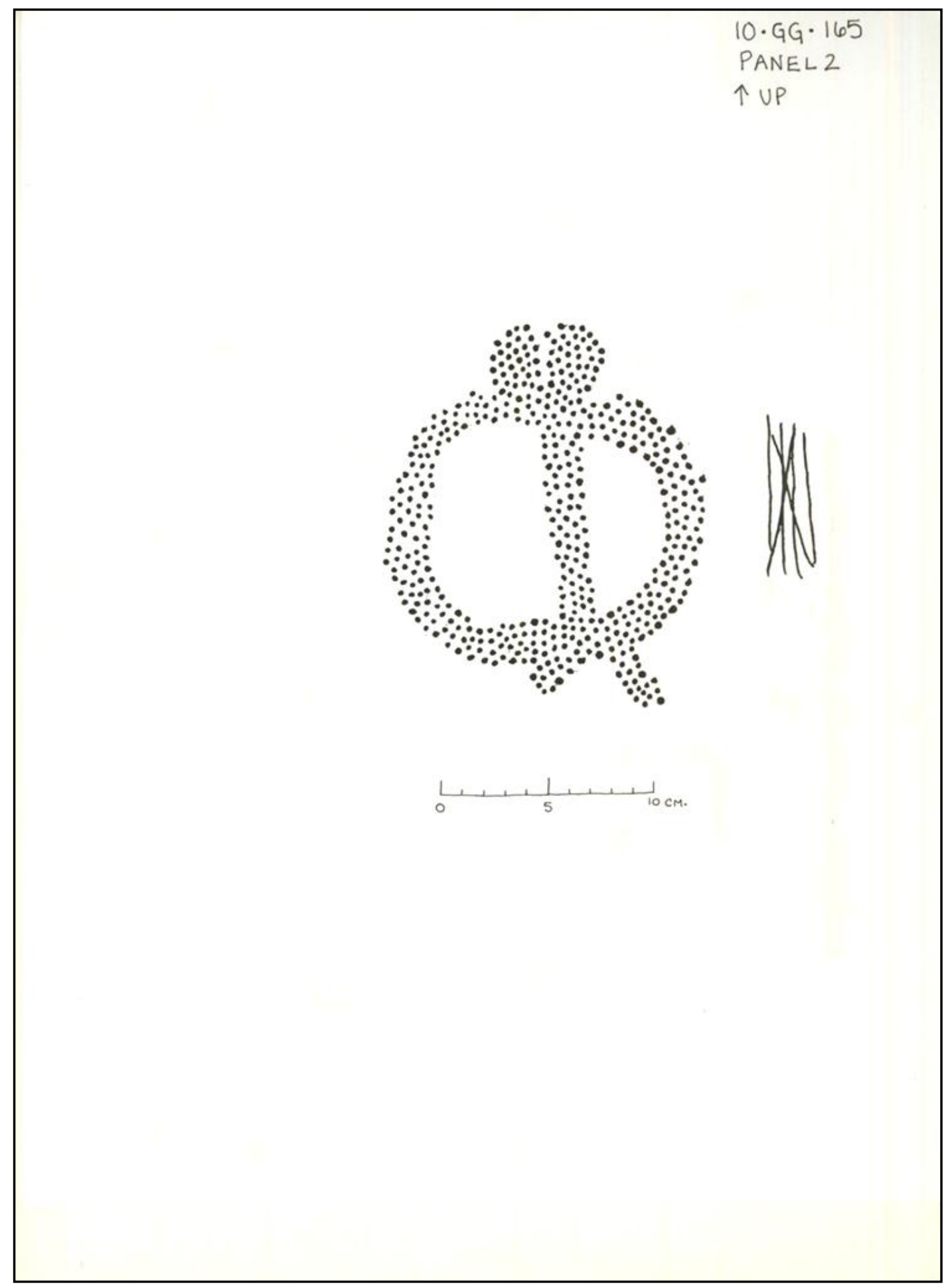

Figure A.4. 10GG165, panel 2. 


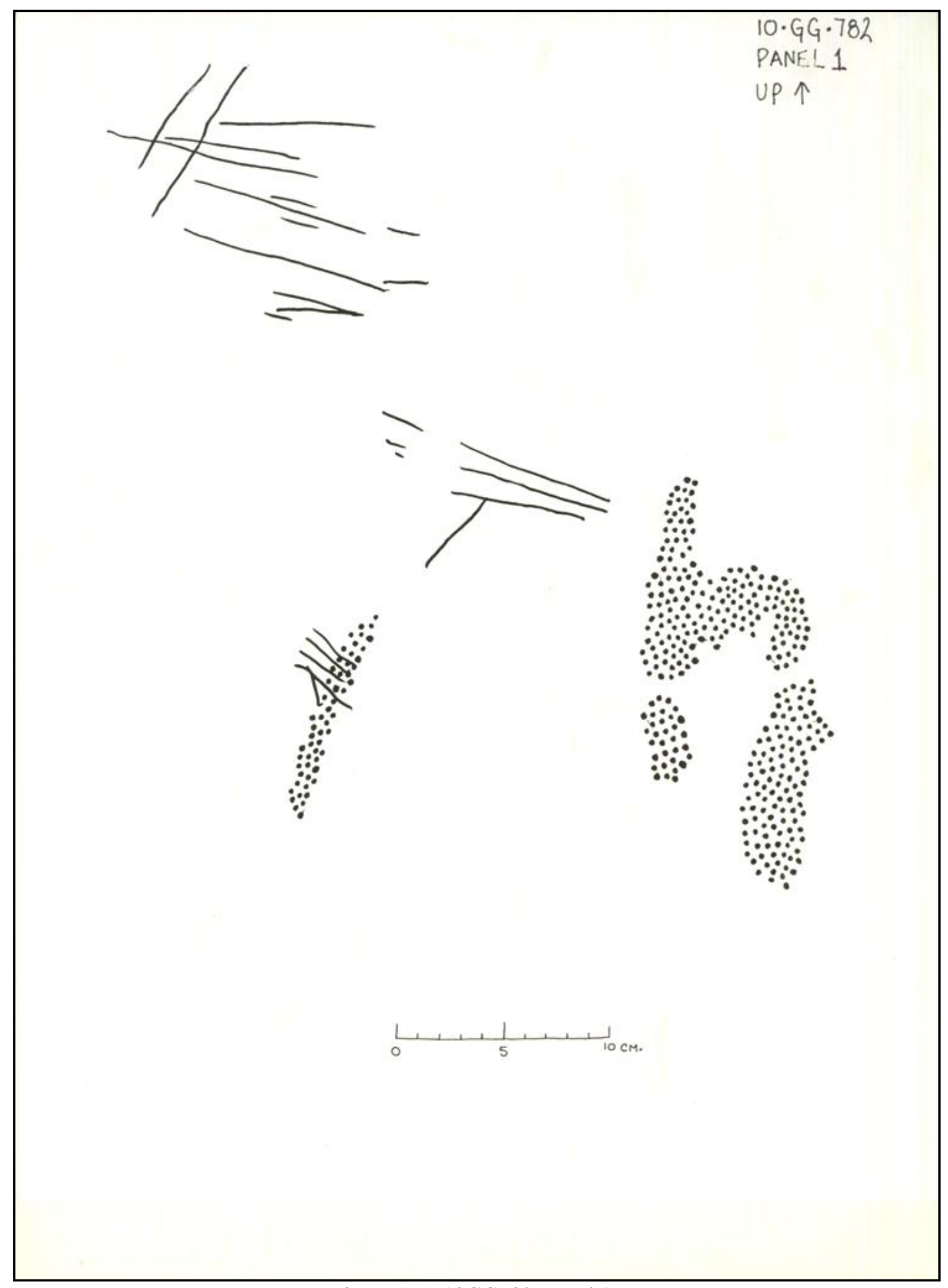

Figure A.5. 10GG782, panel 1. 


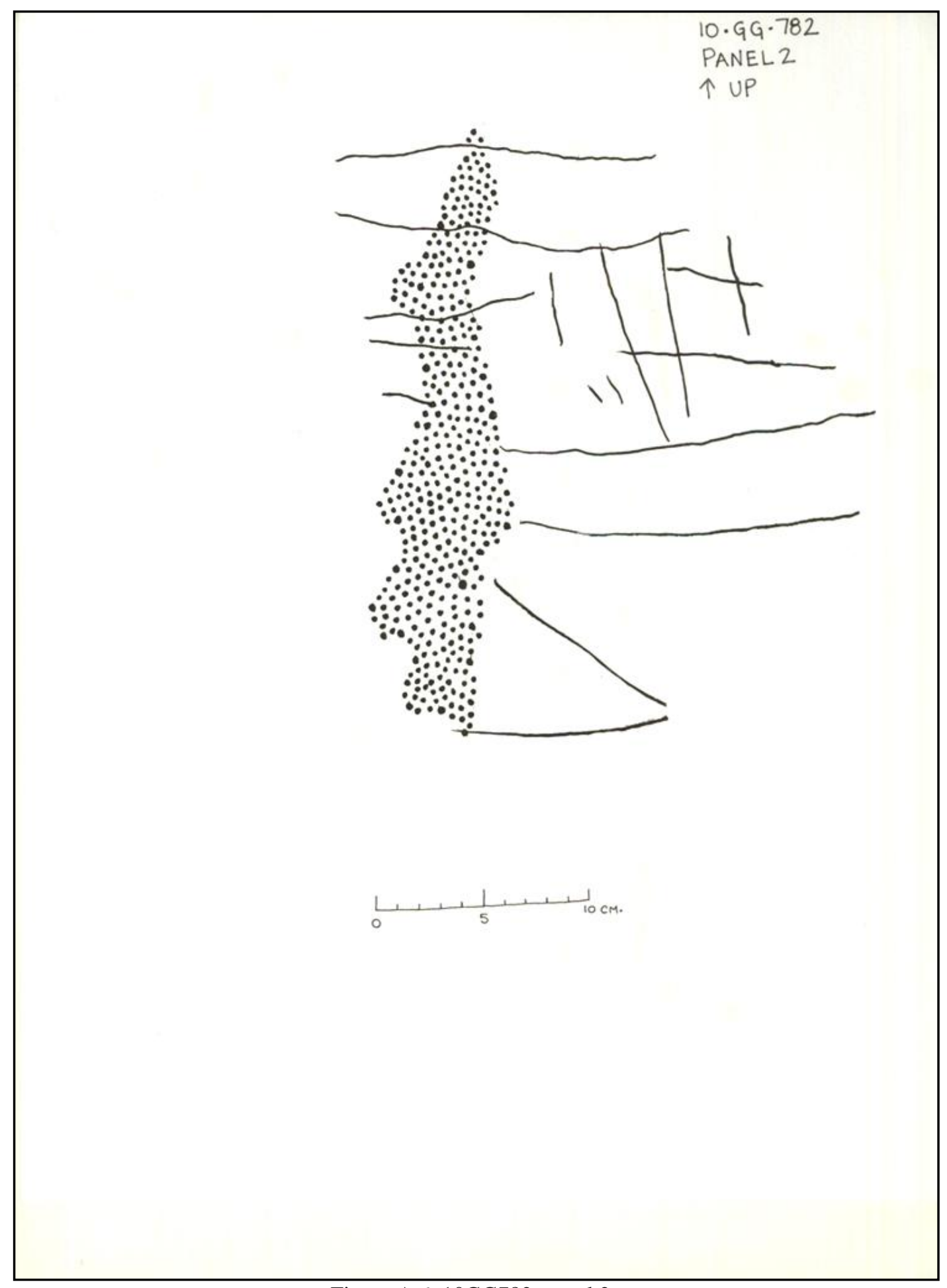

Figure A.6. 10GG782, panel 2. 


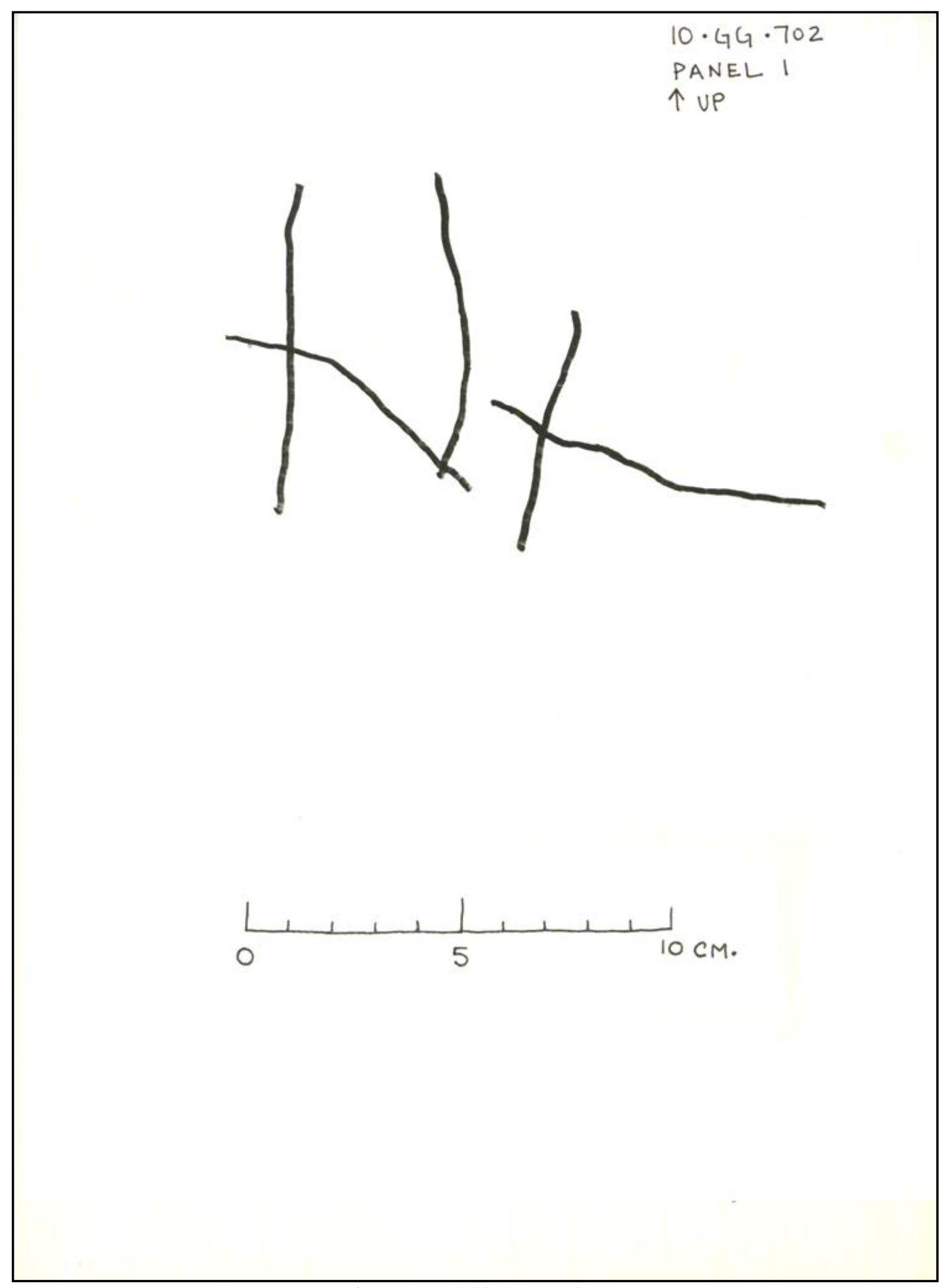

Figure A.7. 10GG702, panel 1.

139 


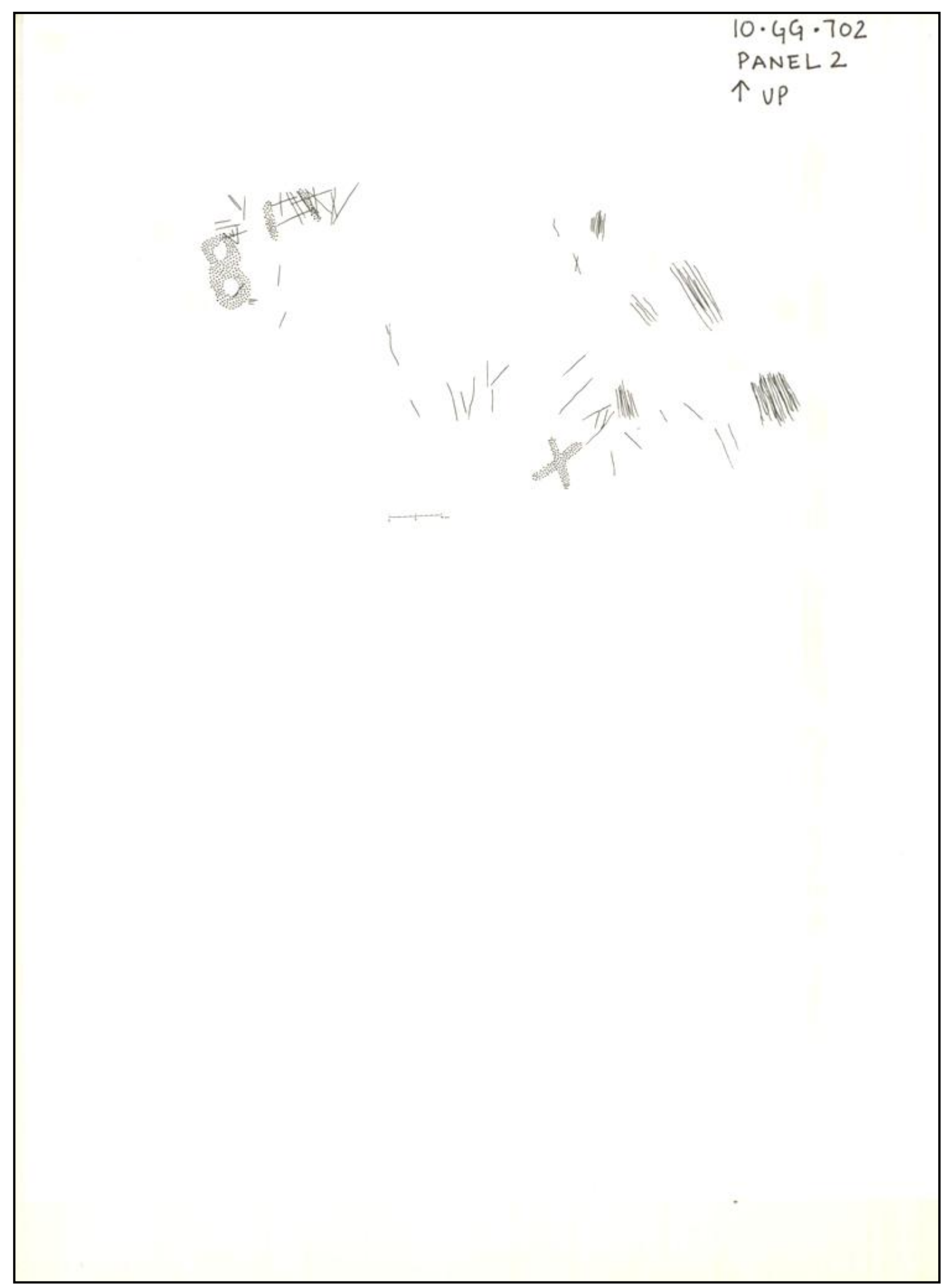

Figure A.8. 10GG702, panel 2. 


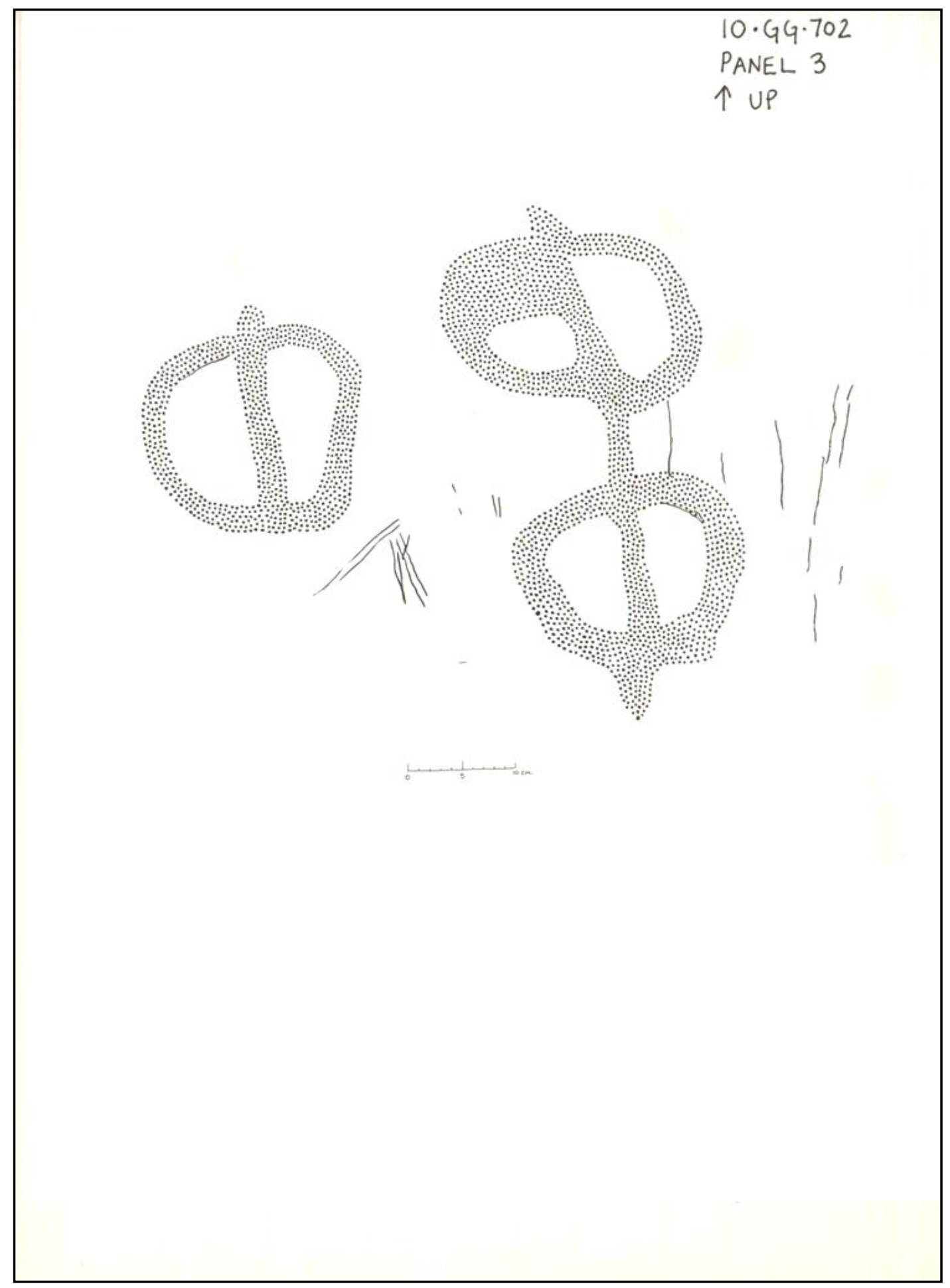

Figure A.9. 10GG702, panel 3. 


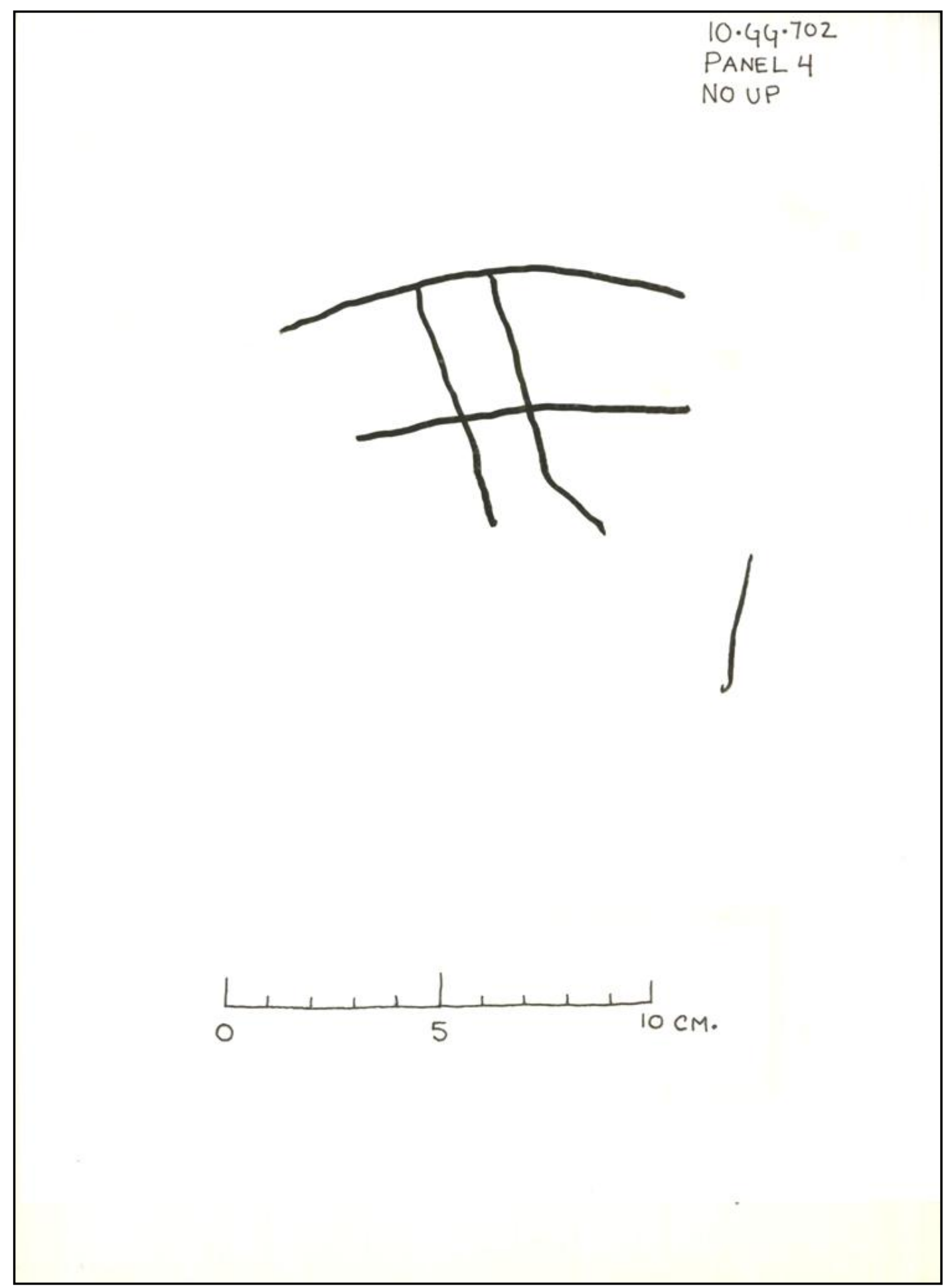

Figure A.10. 10GG702, panel 4. 


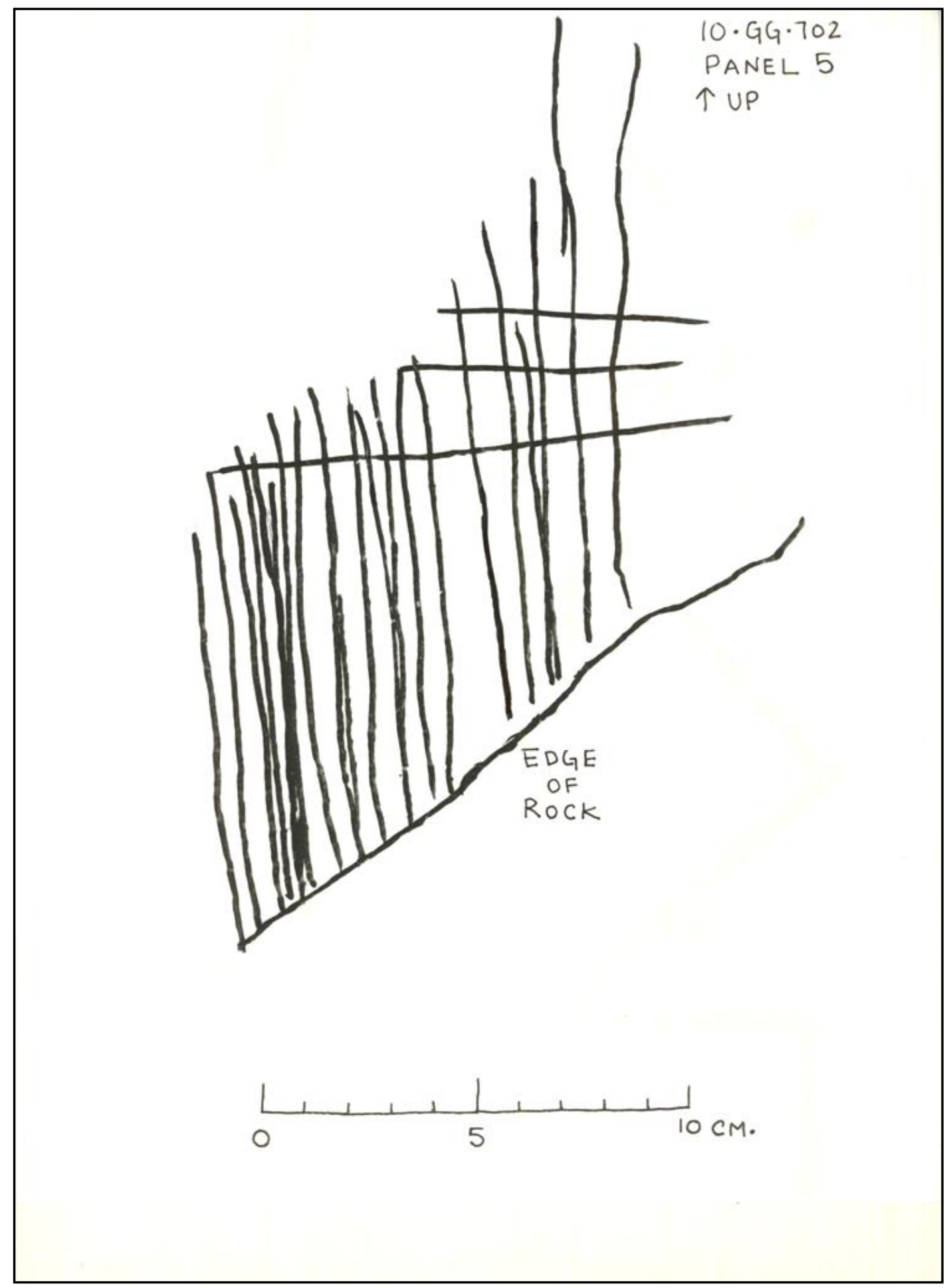

Figure A.11. 10GG702, panel 5 . 


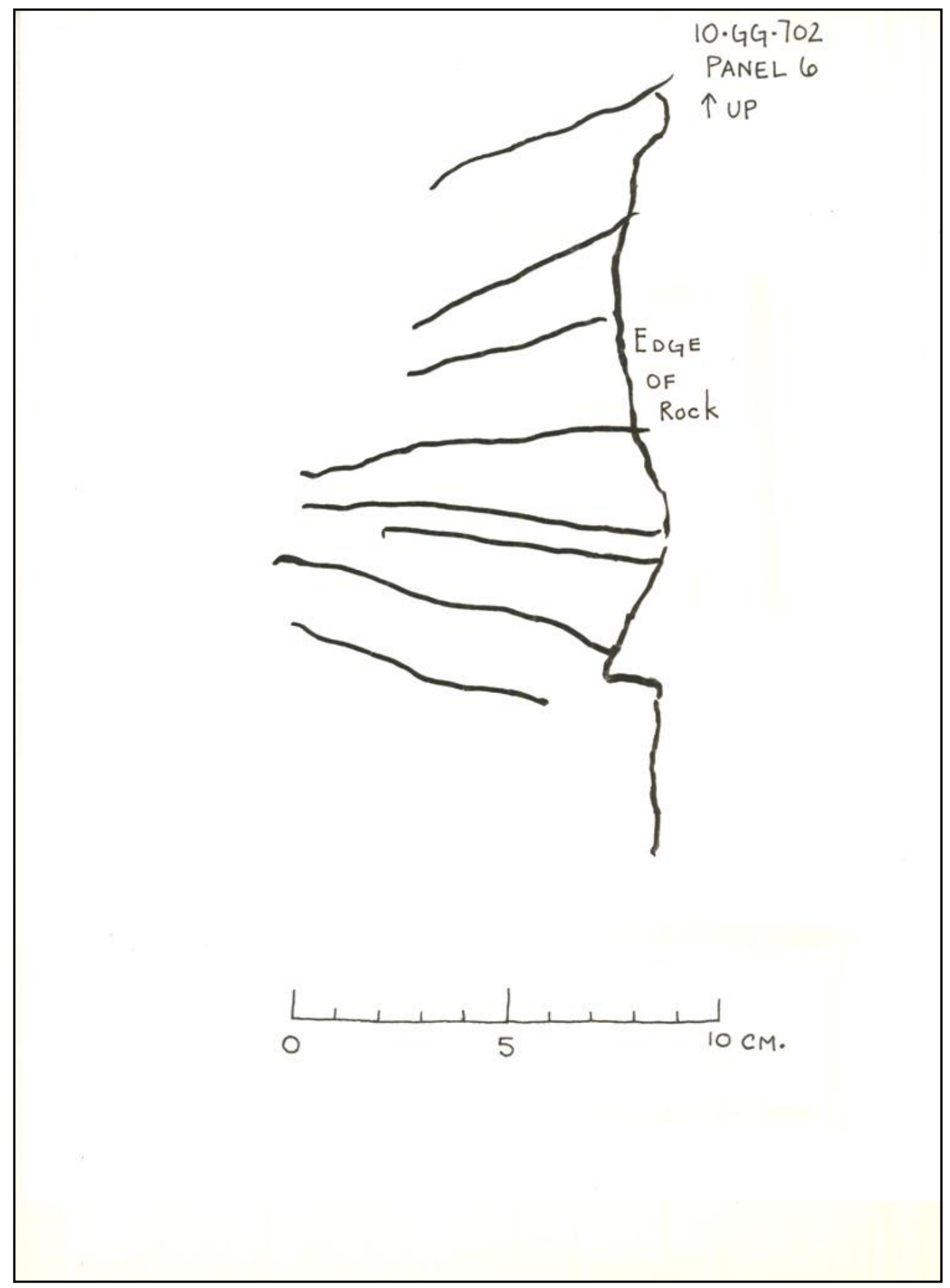

Figure A.12. 10GG702, panel 6. 


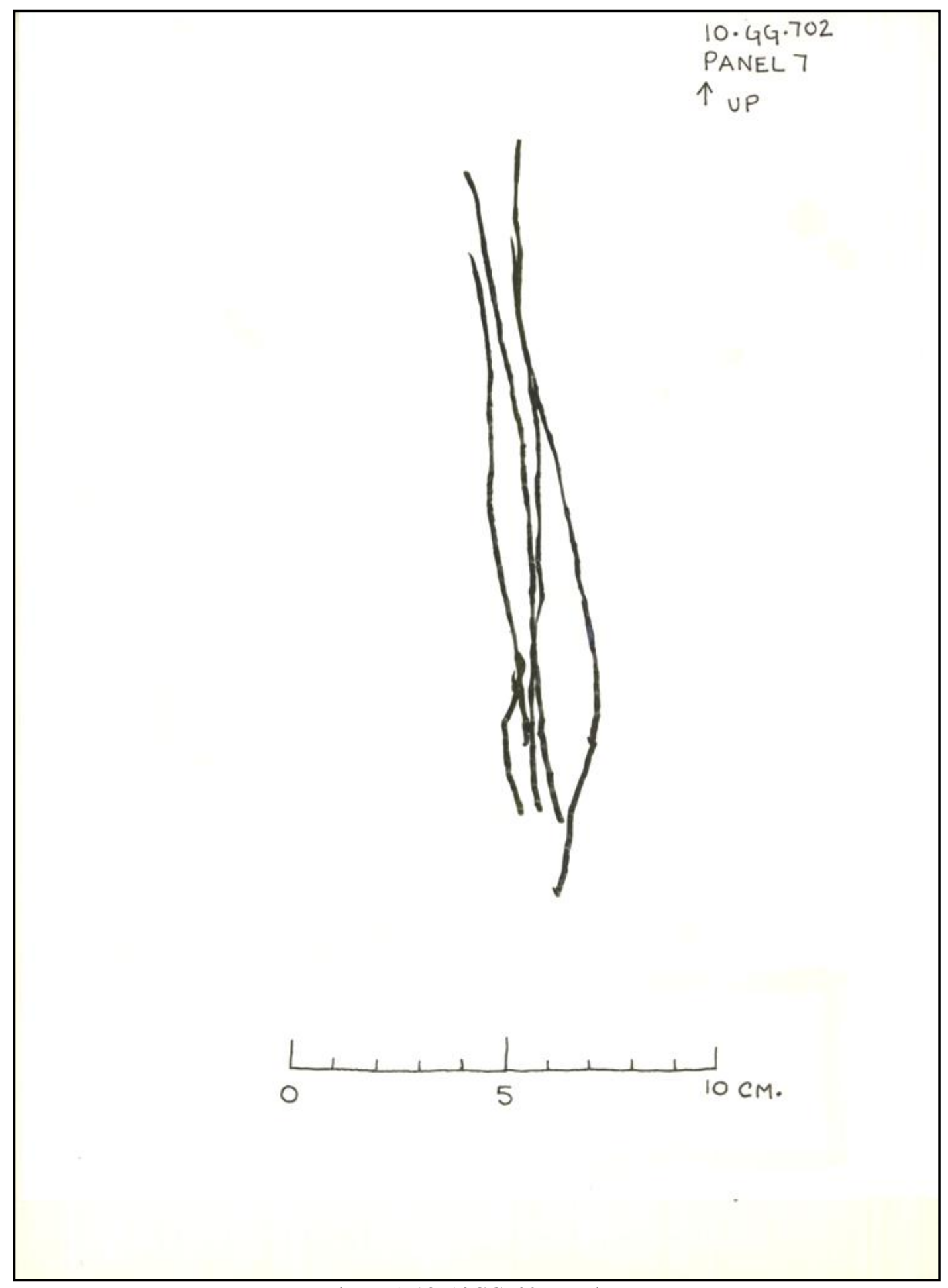

Figure A.13. 10GG702, panel 7. 


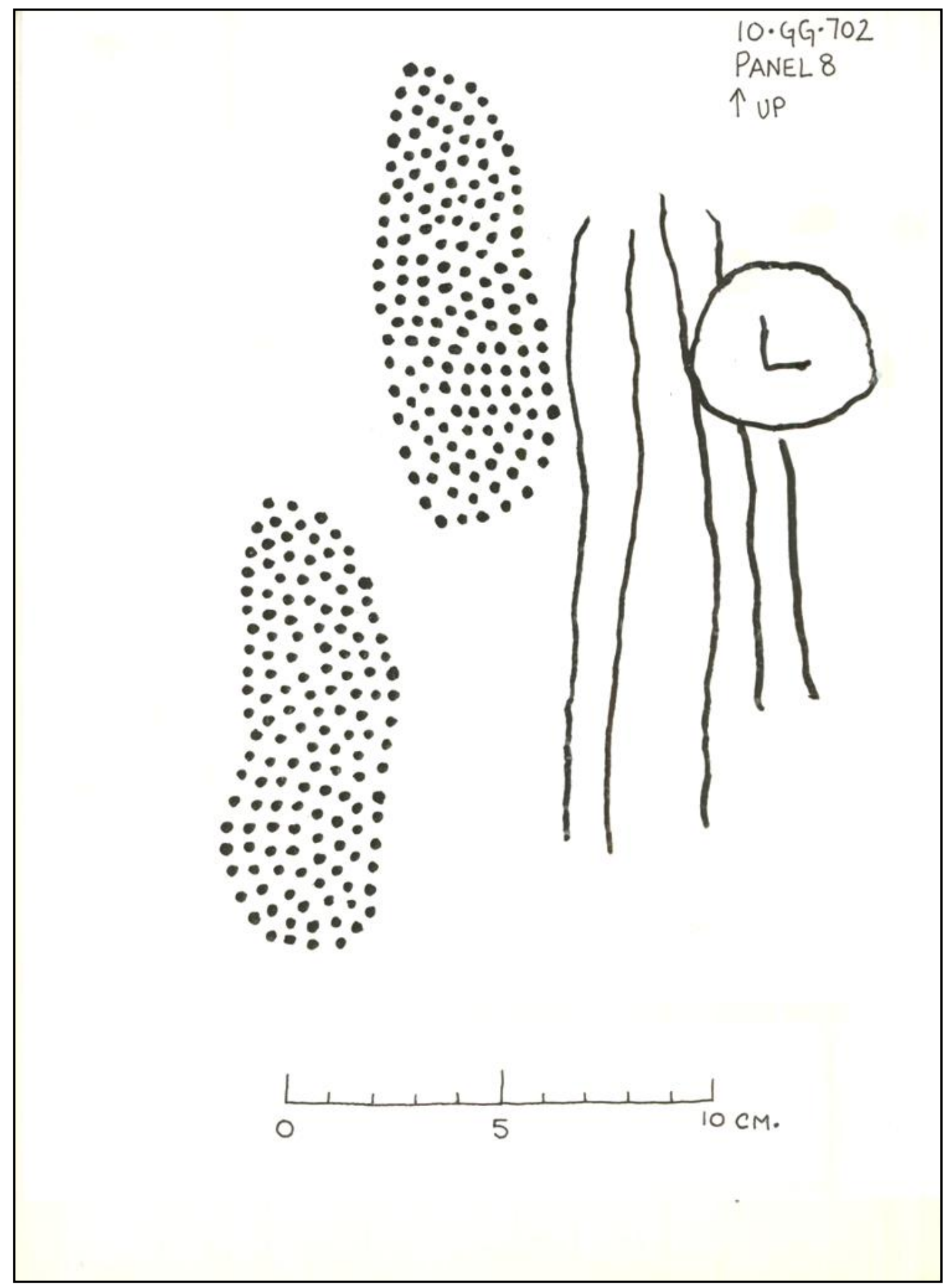

Figure A.14. 10GG702, panel 8. 


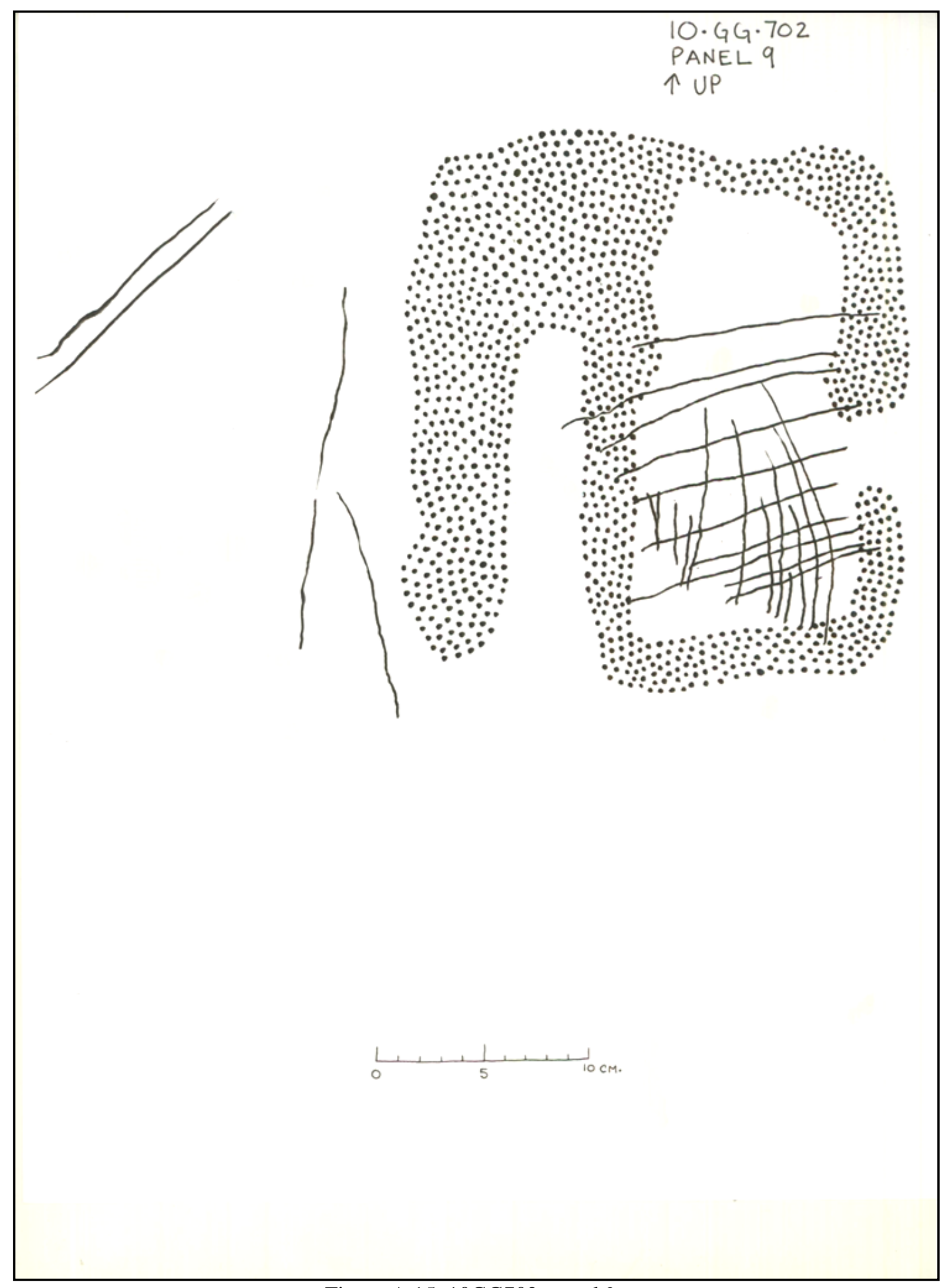

Figure A.15. 10GG702, panel 9. 


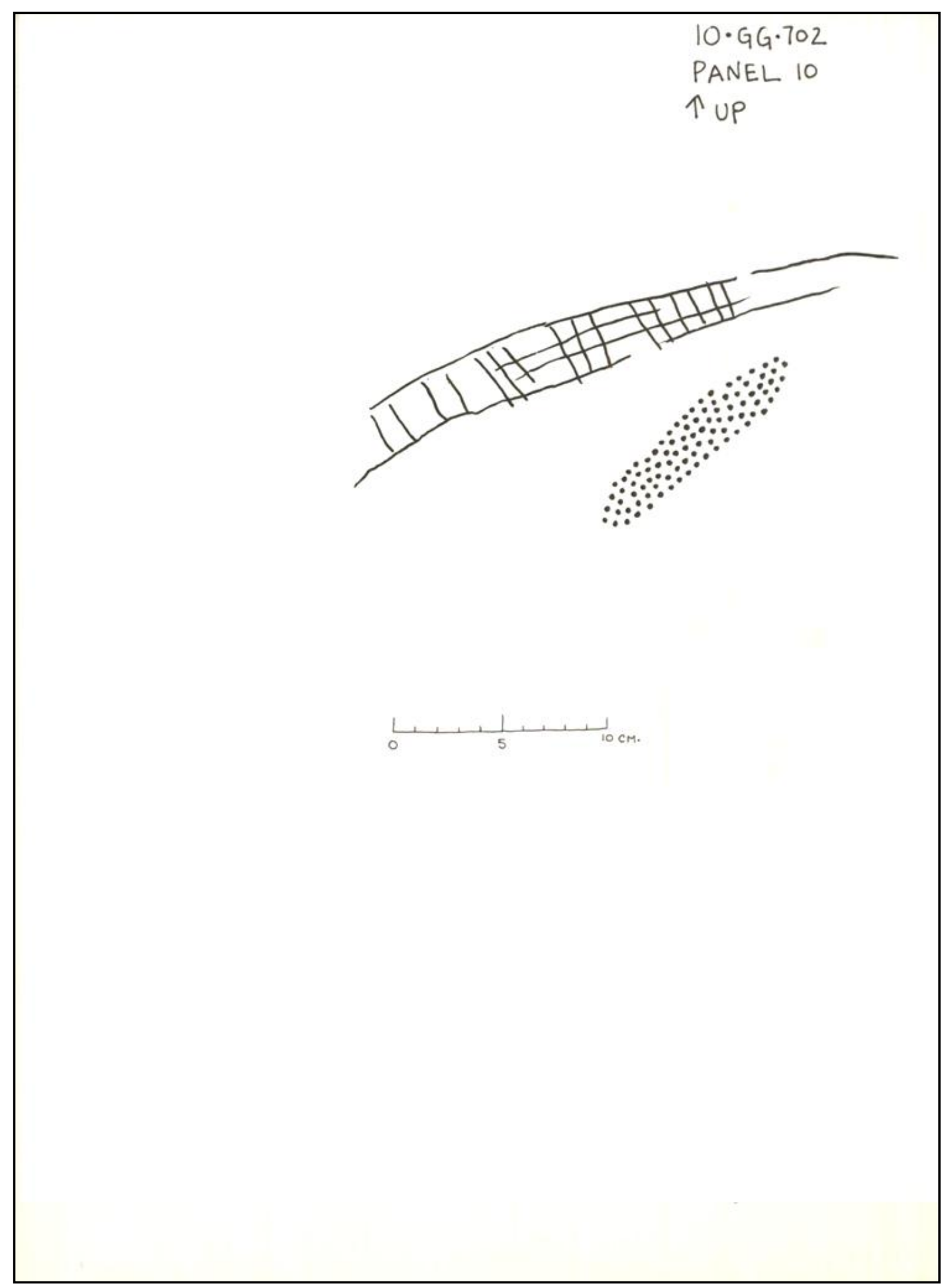

Figure A.16. 10GG702, panel 10. 


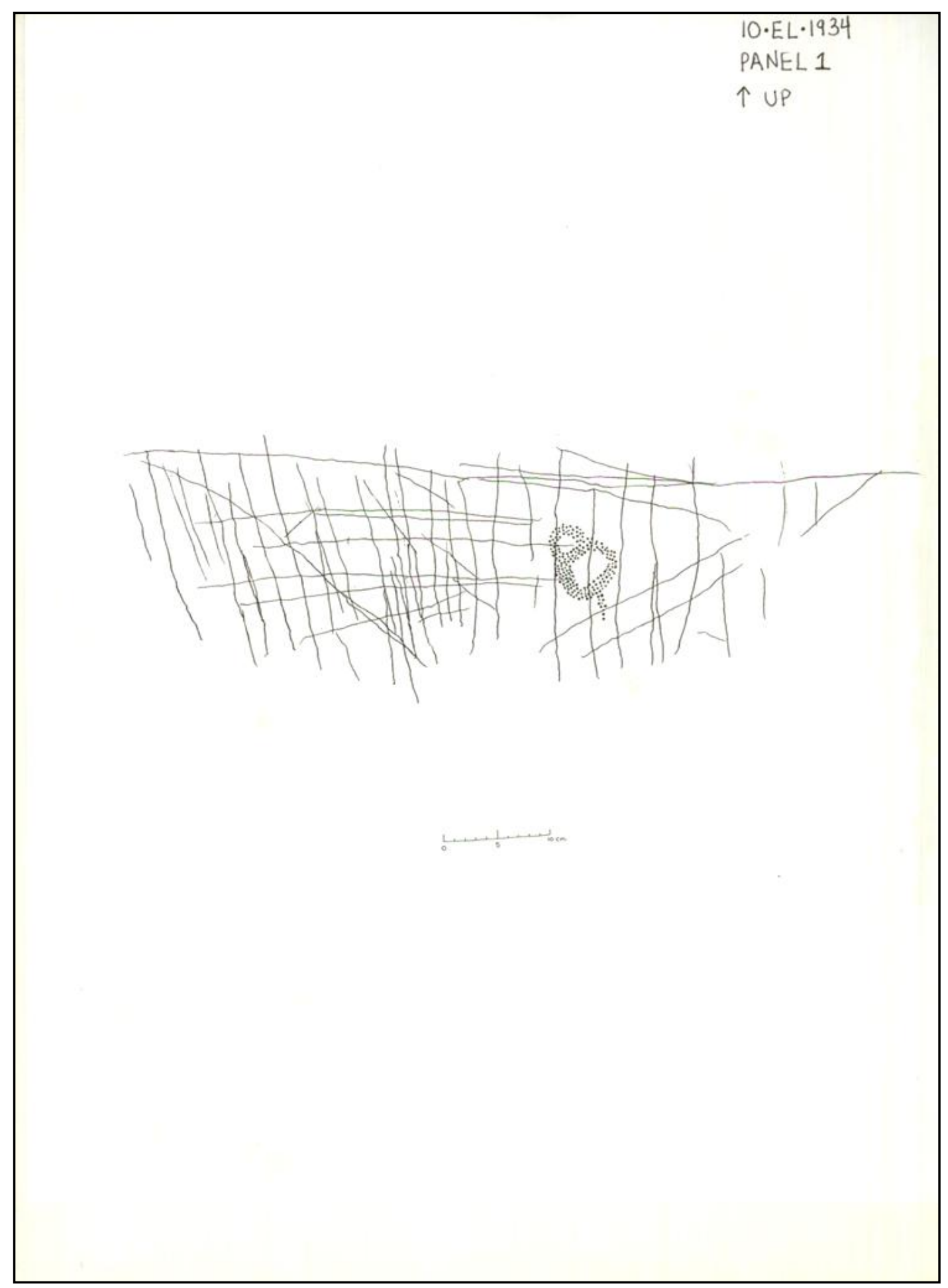

Figure A.17. 10EL1934, panel 1. 


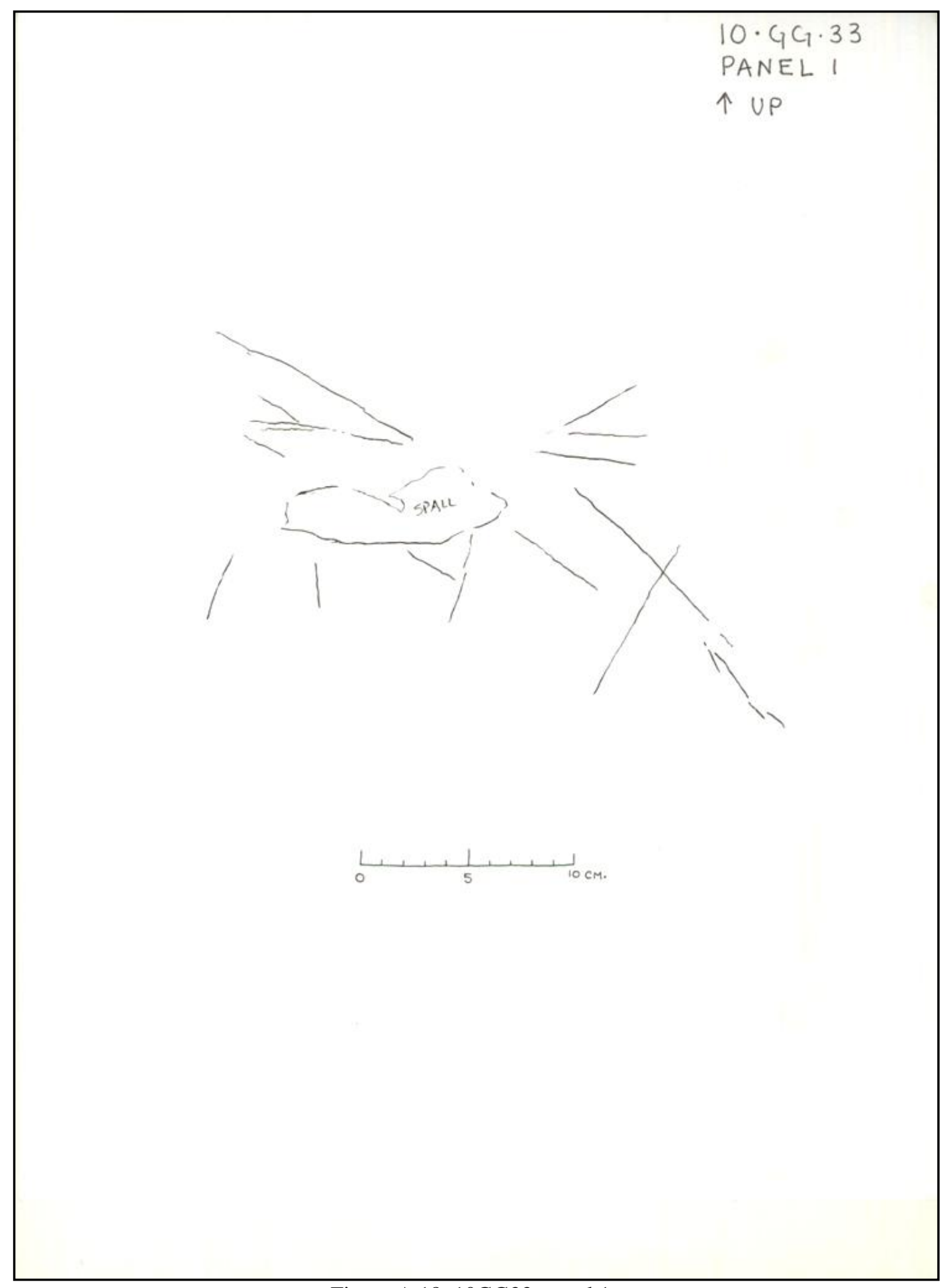

Figure A.18. 10GG33, panel 1. 


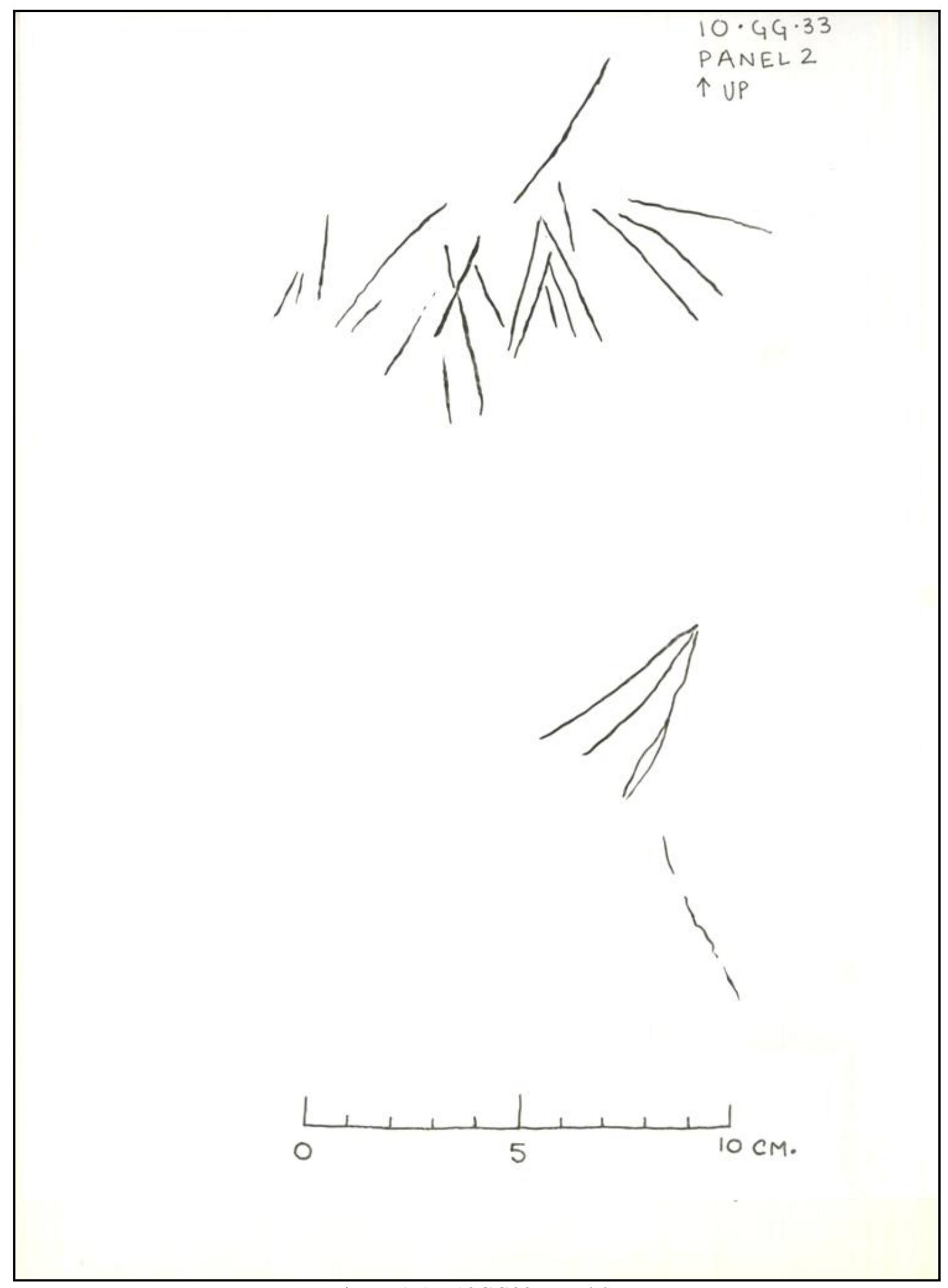

Figure A.19. 10GG30, panel 2. 


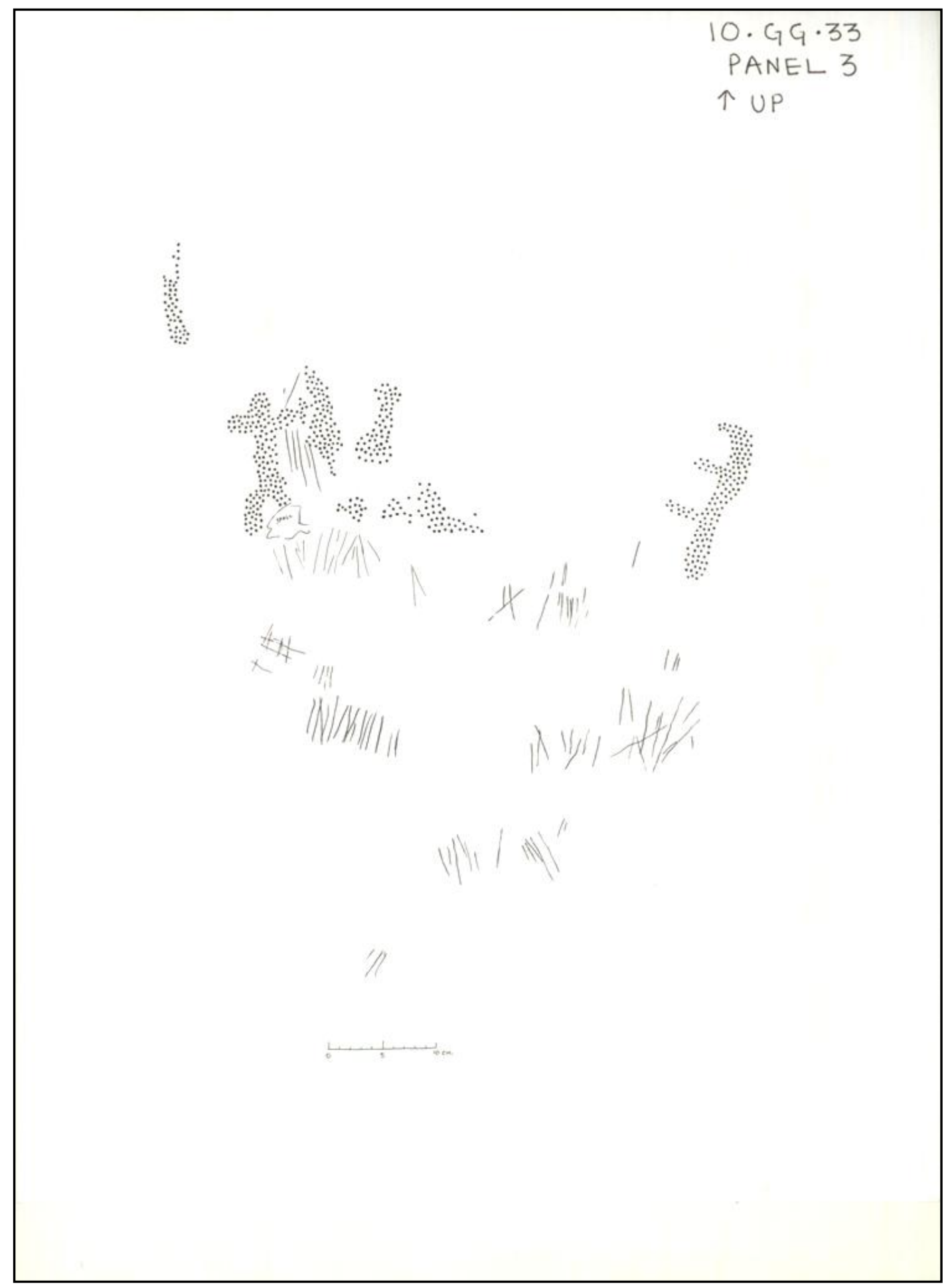

Figure A.20. 10GG33, panel 3. 


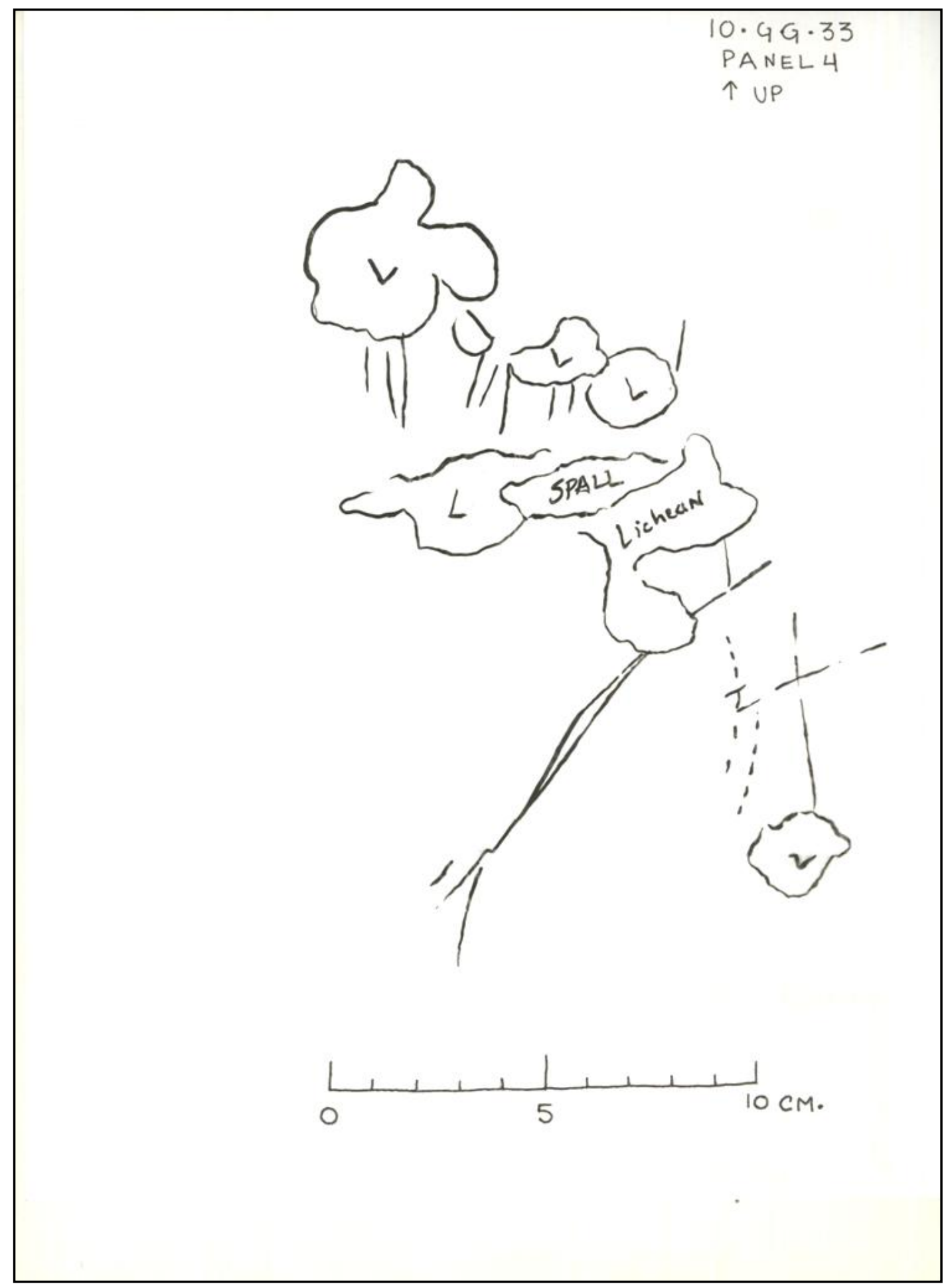

Figure A.21. 10GG33, panel 4. 


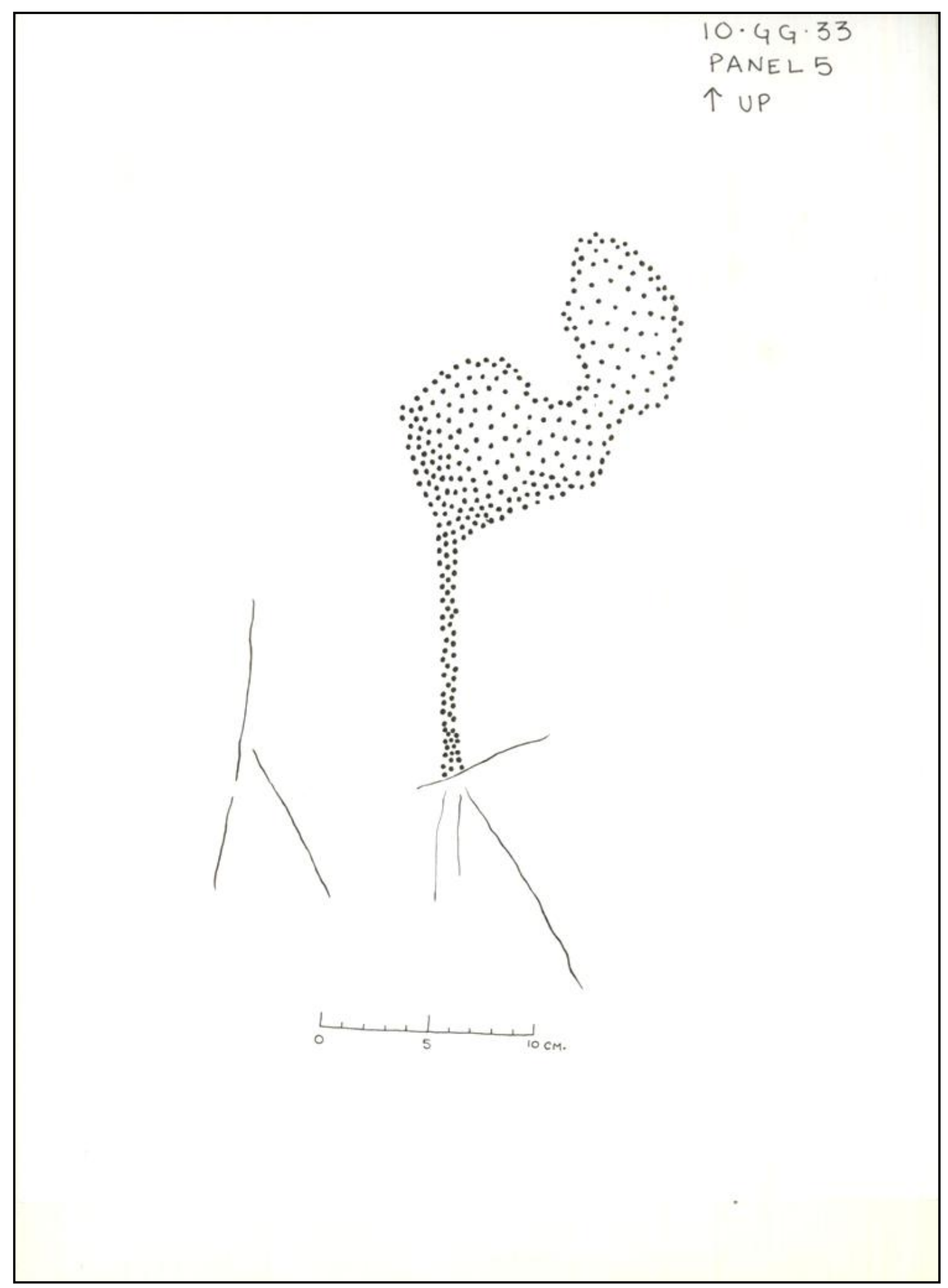

Figure A.22. 10GG33, panel 5. 


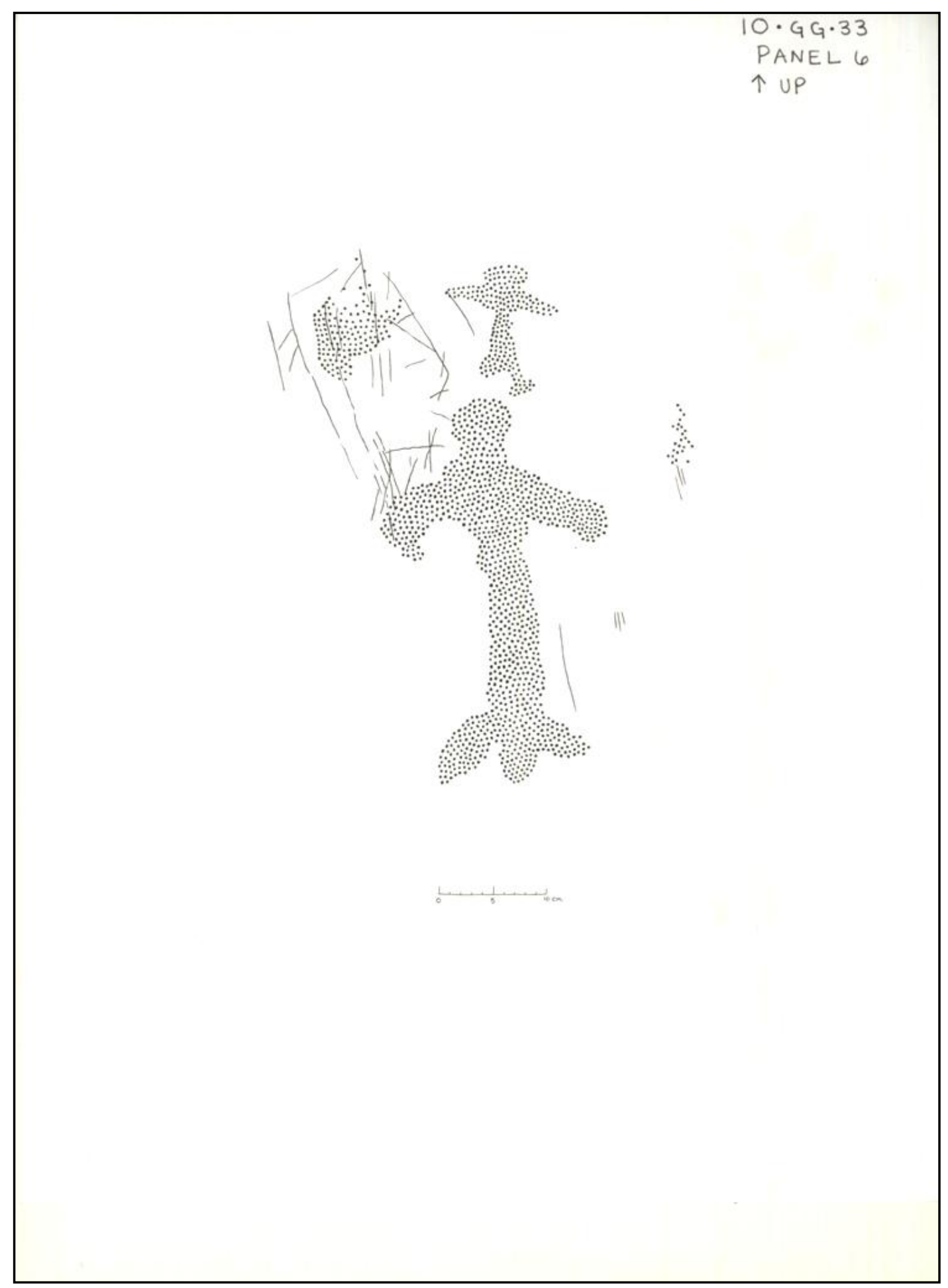

Figure A.23. 10GG33, panel 6. 


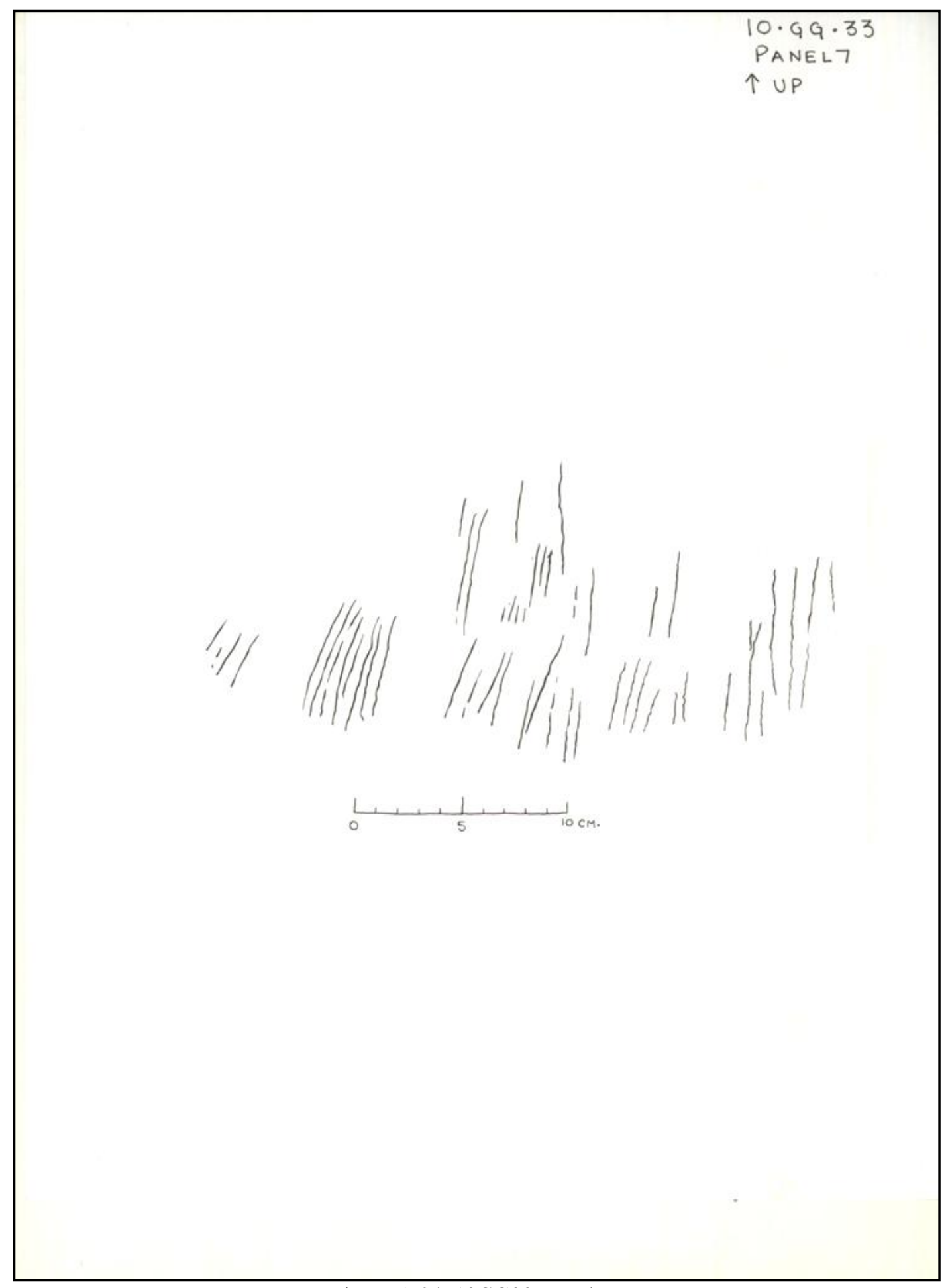

Figure A.24. 10GG33, panel 7. 


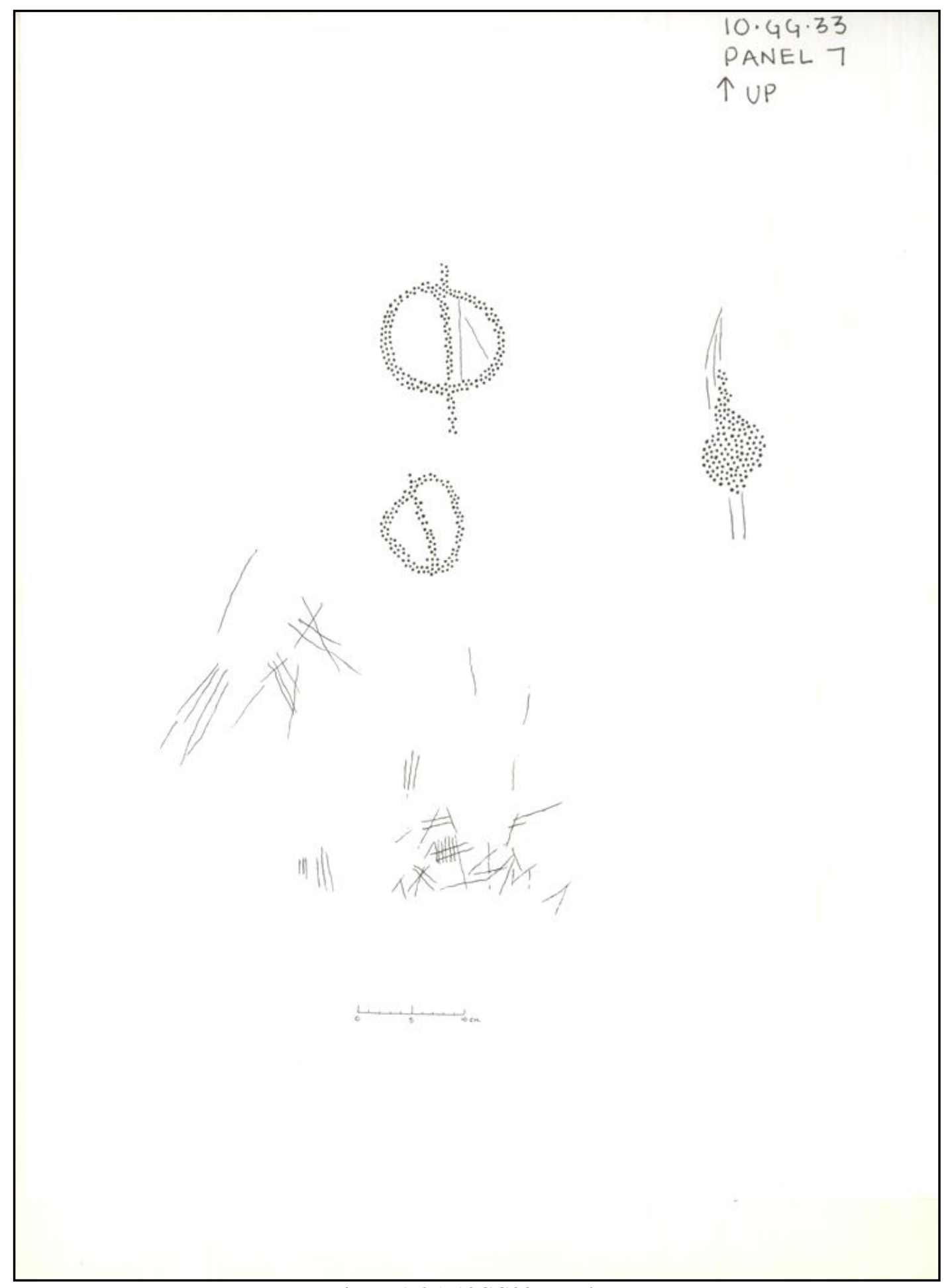

Figure A.25. 10GG33, panel 7. 


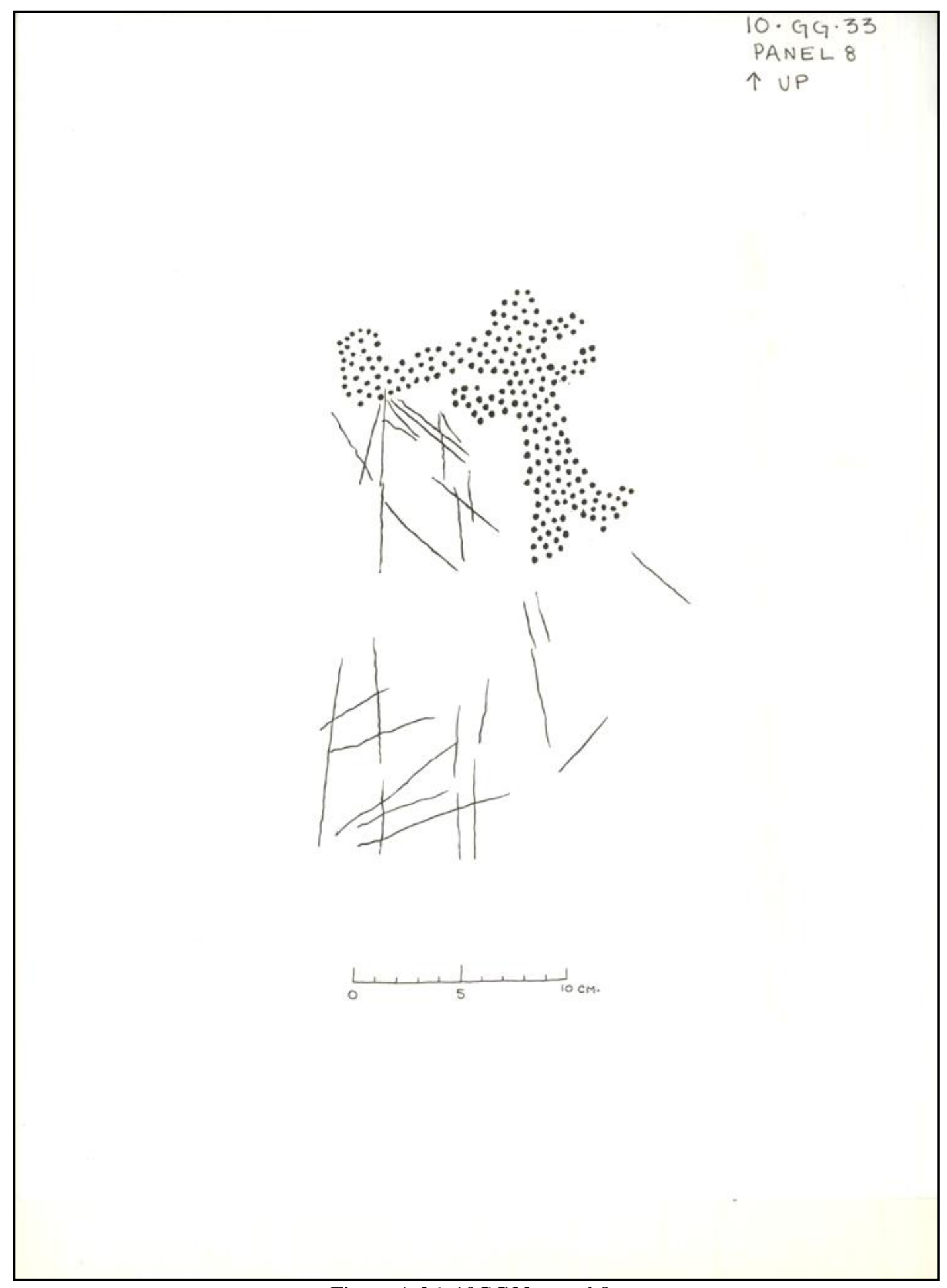

Figure A.26. 10GG33, panel 8. 


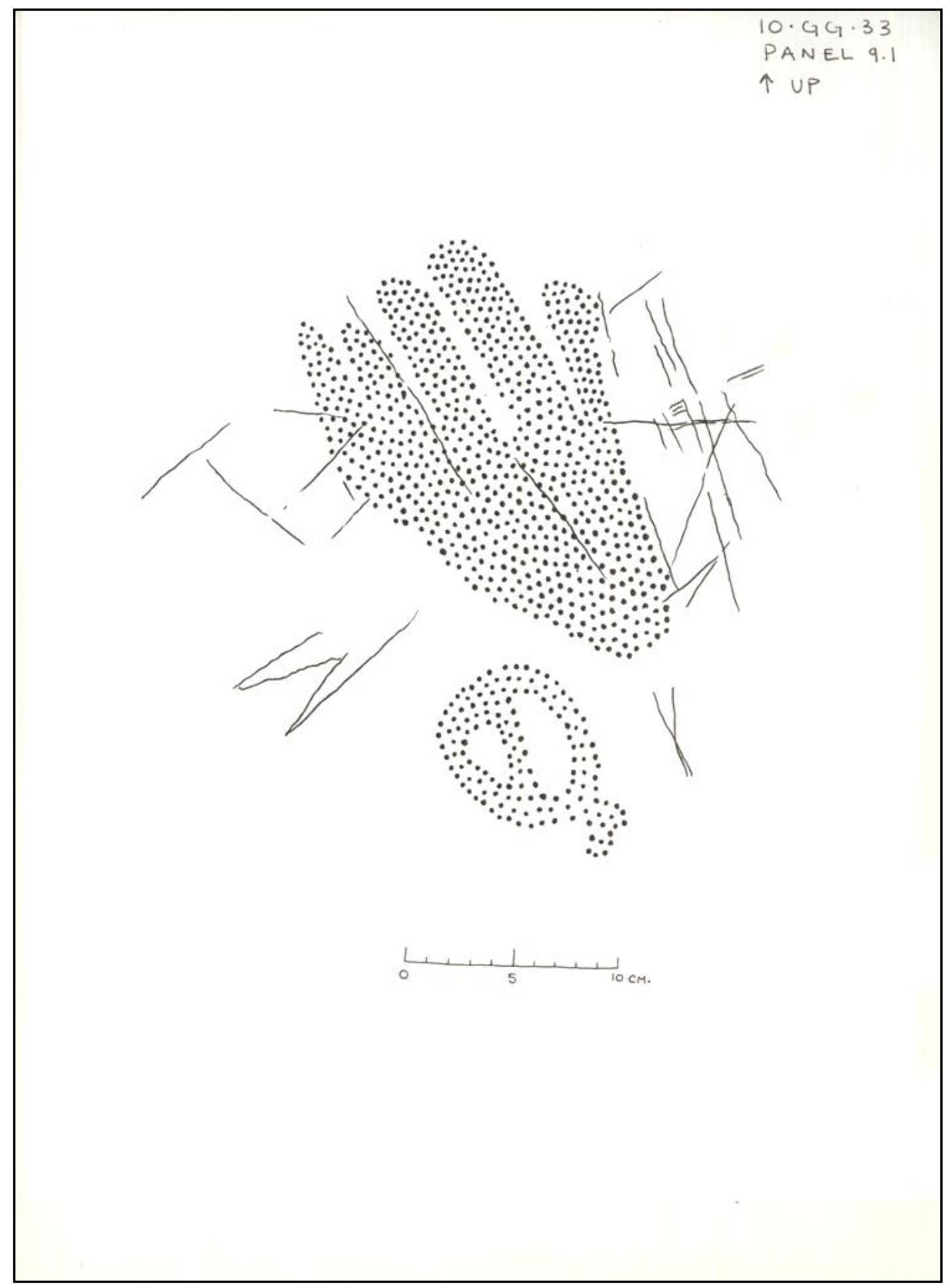

Figure A.27. 10GG33, panel 9.1. 


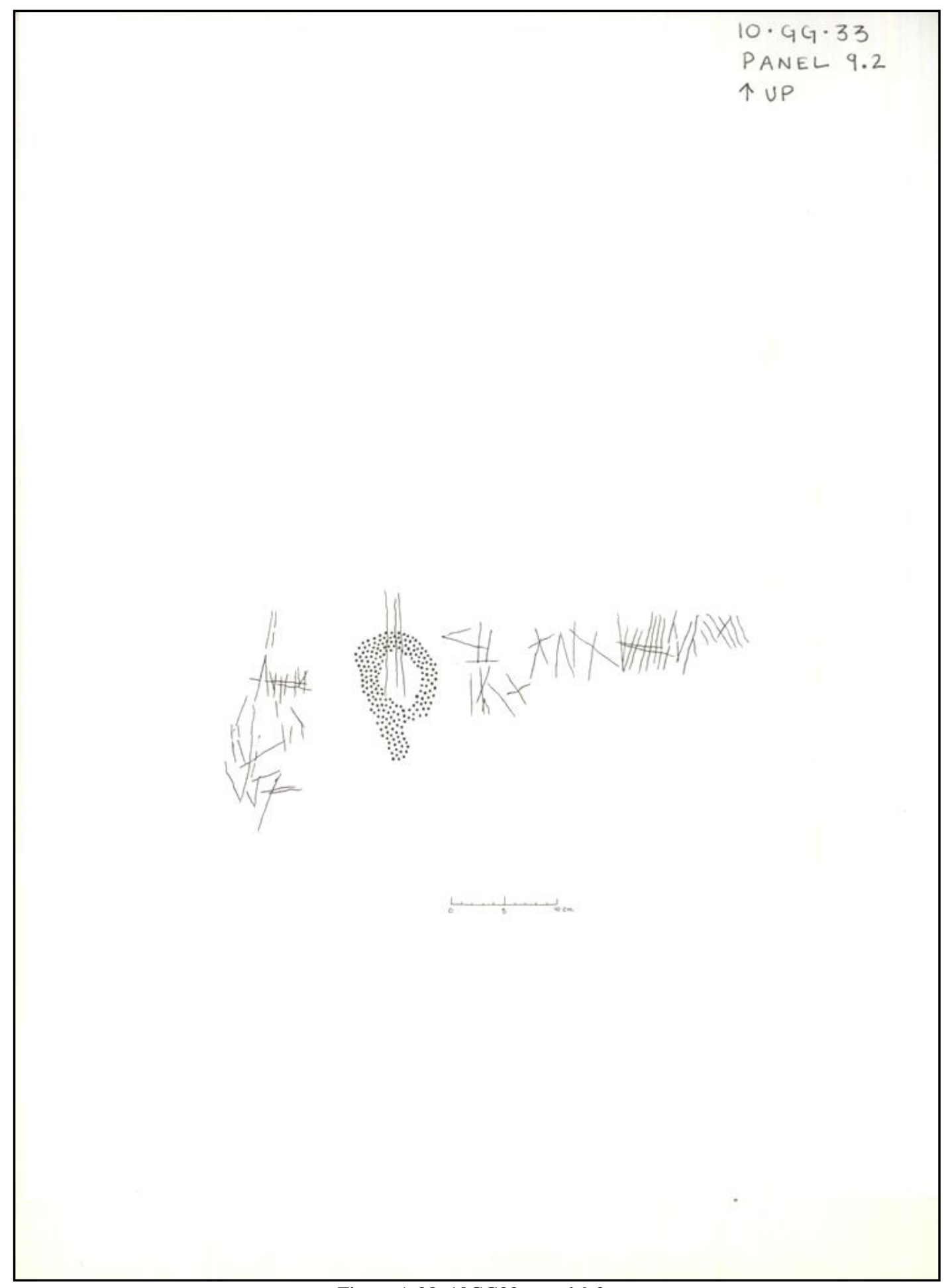

Figure A.28. 10GG33, panel 9.2. 


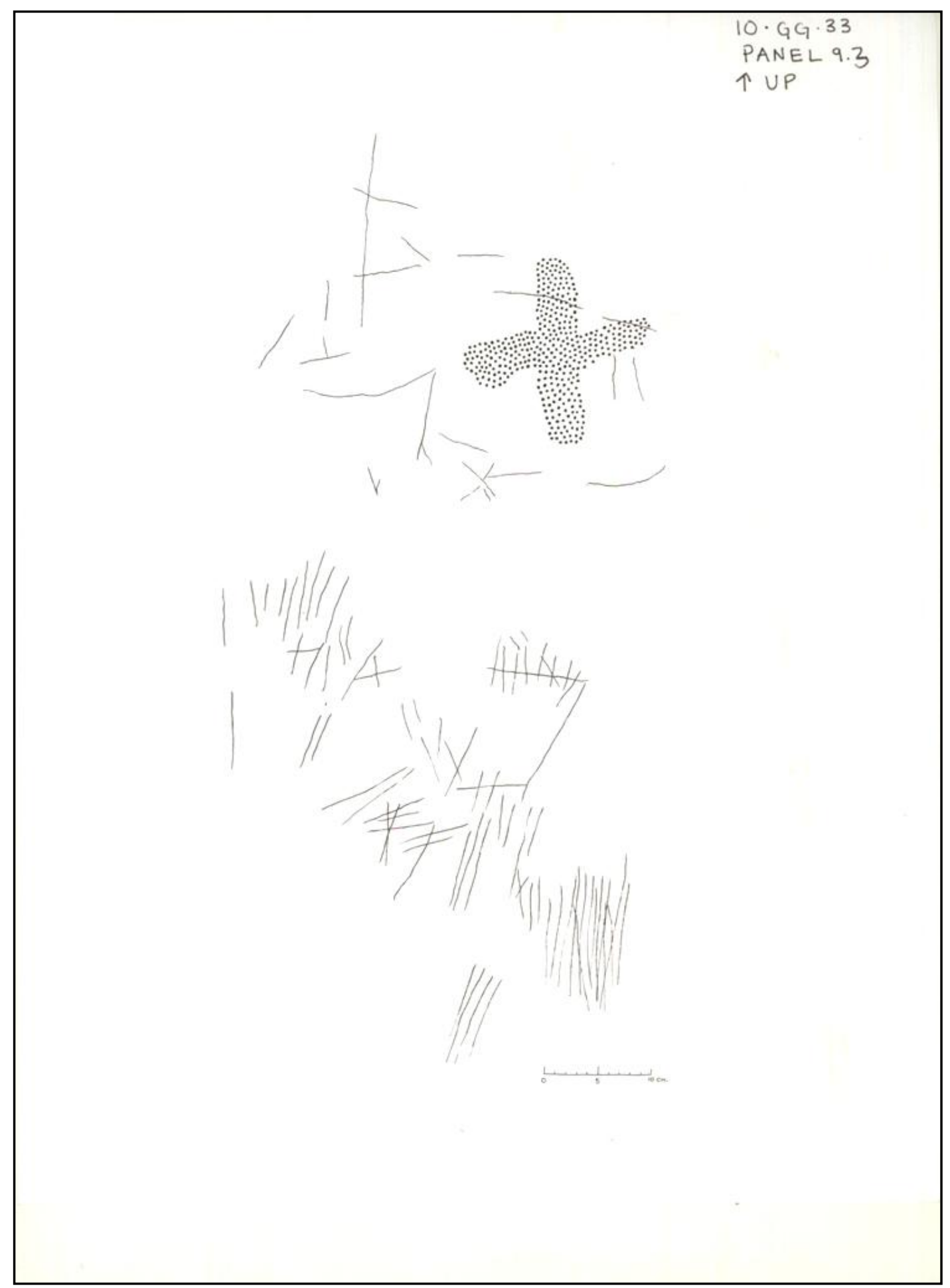

Figure A.29. 10GG33, panel 9.3. 


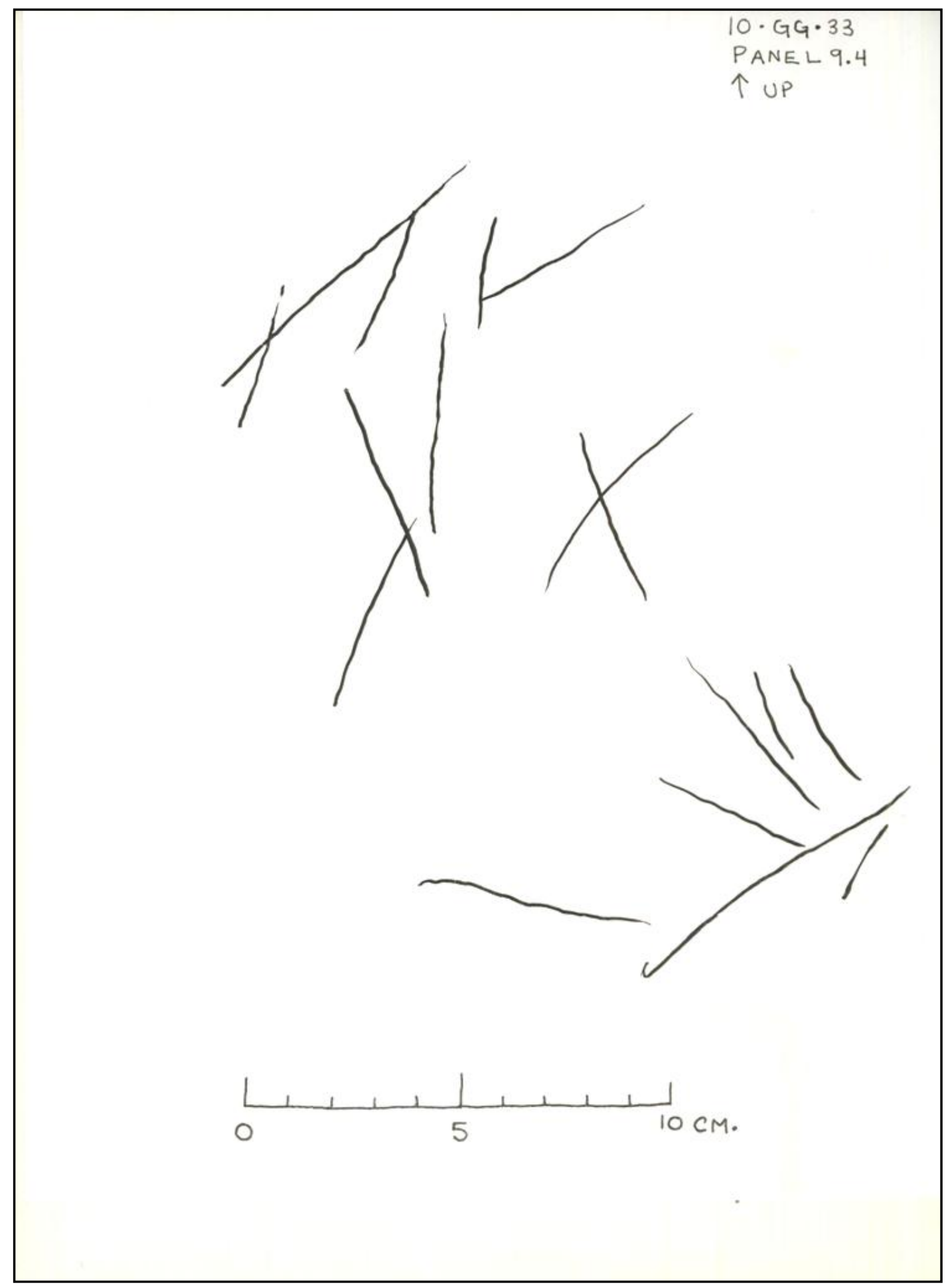

Figure A.30, 10GG33, panel 9.4 


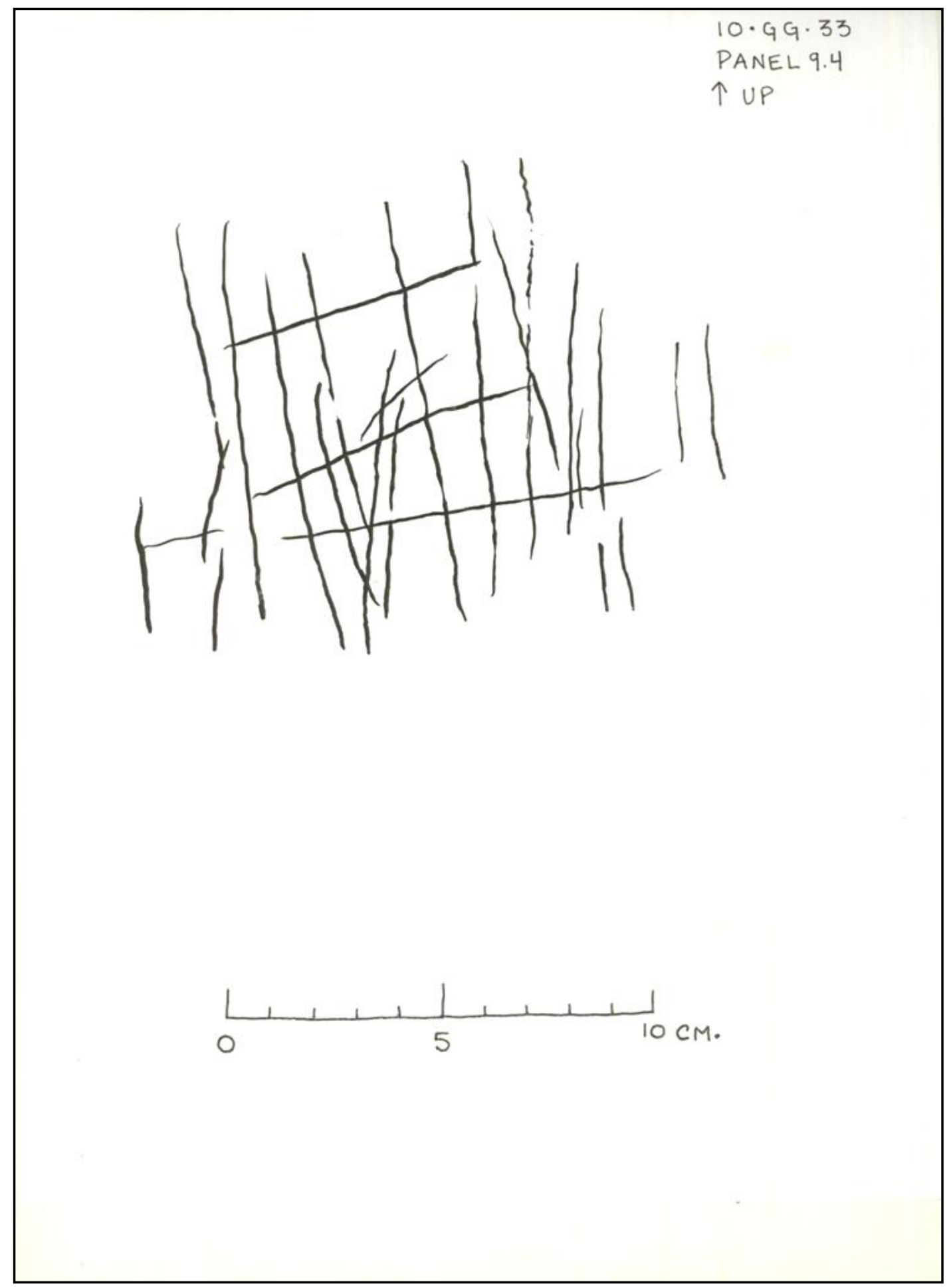

Figure A.31. 10GG33, panel 9.4. 


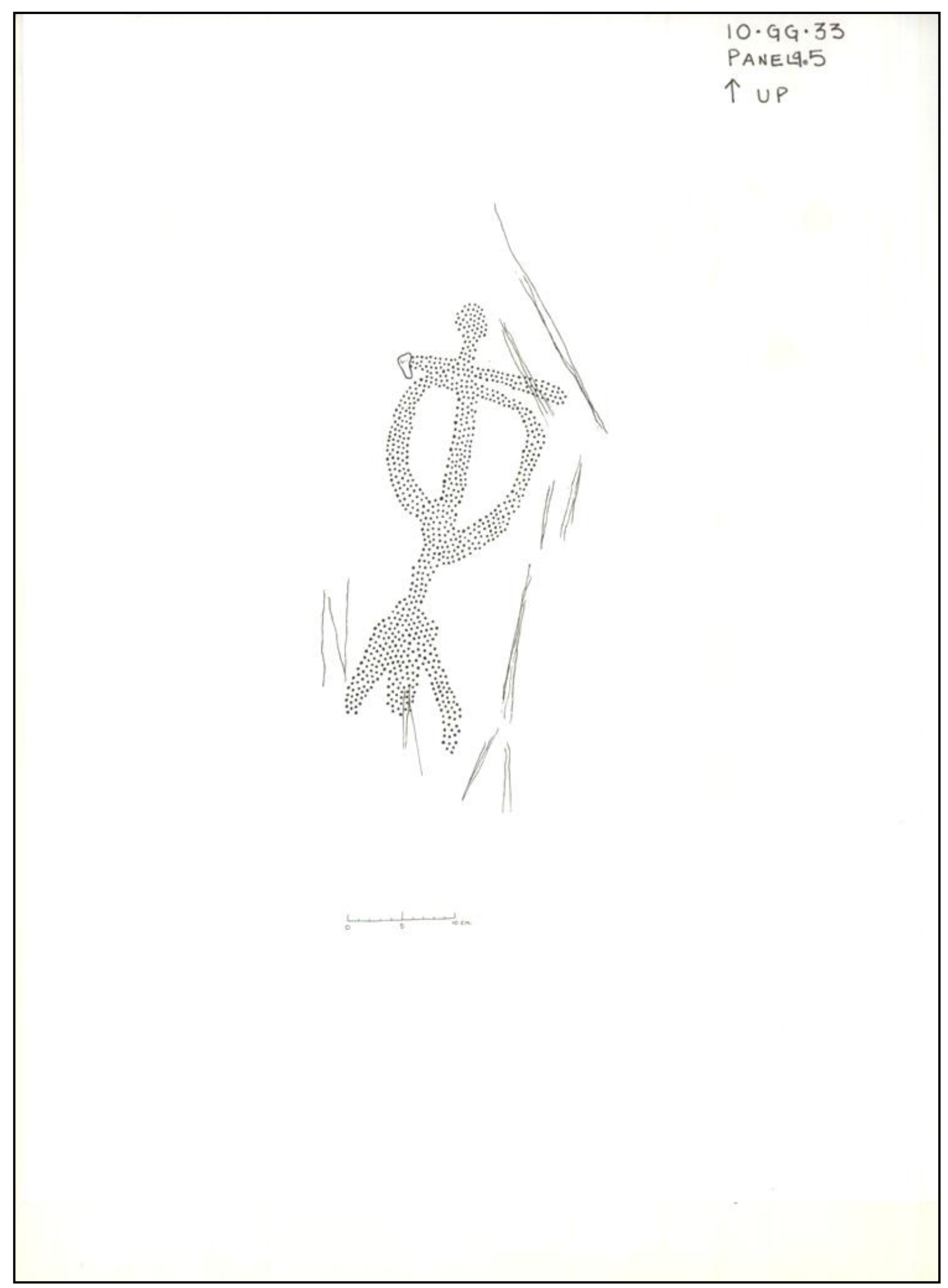

Figure A.32. 10GG33, panel 9.5. 


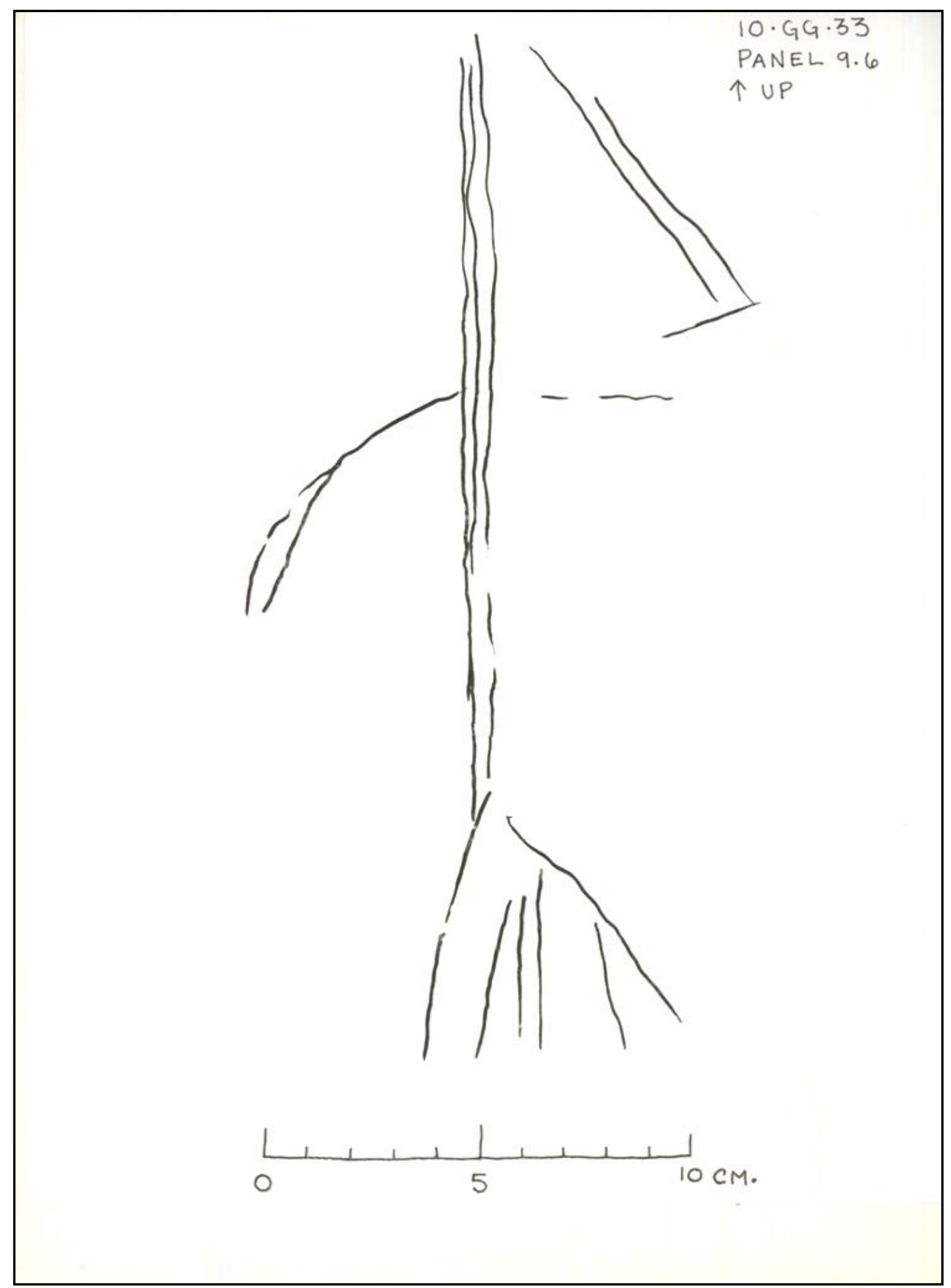

Figure A.33. 10GG33, panel 9.6. 


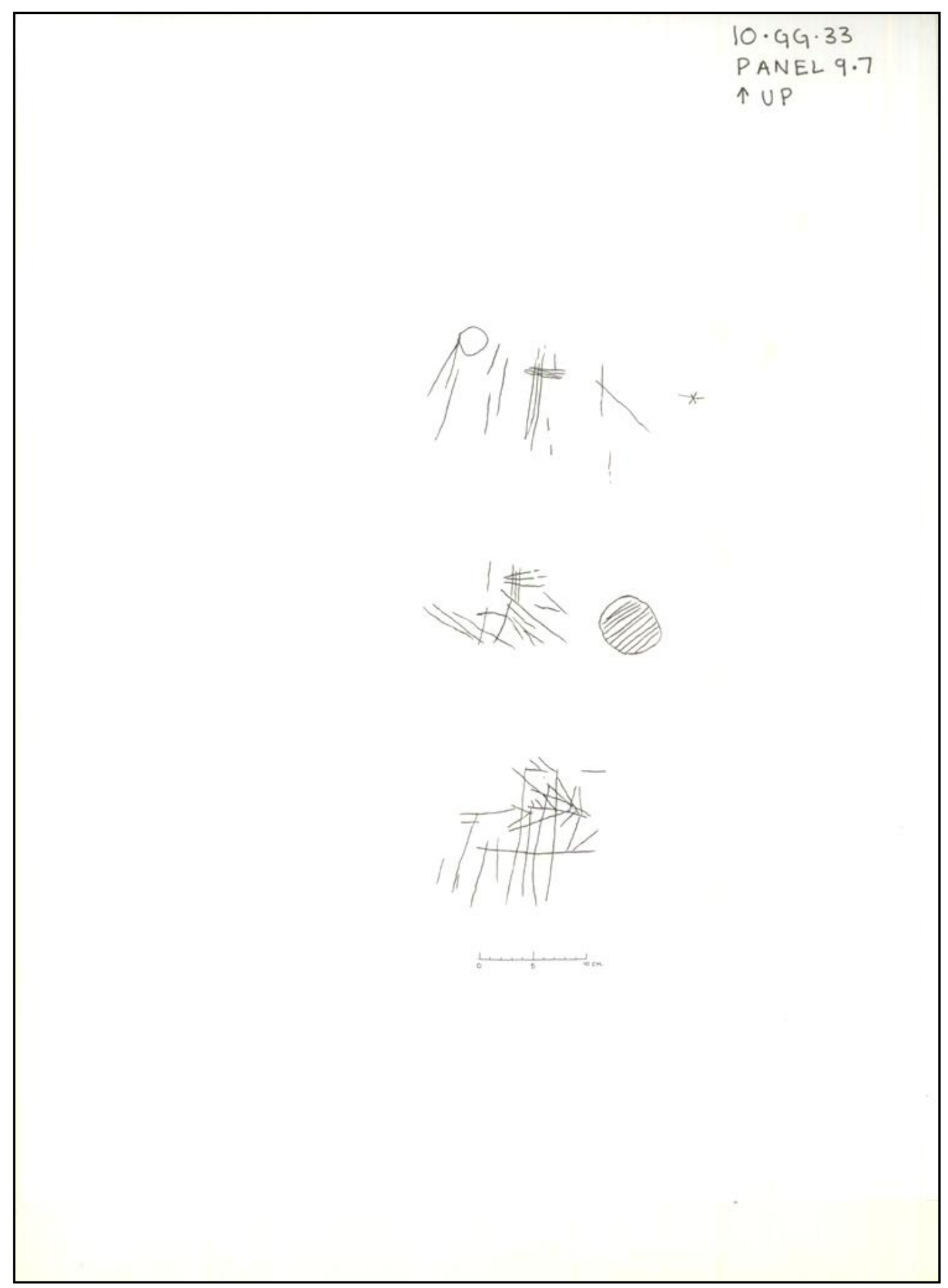

Figure A.34. 10GG33, panel 9.7. 


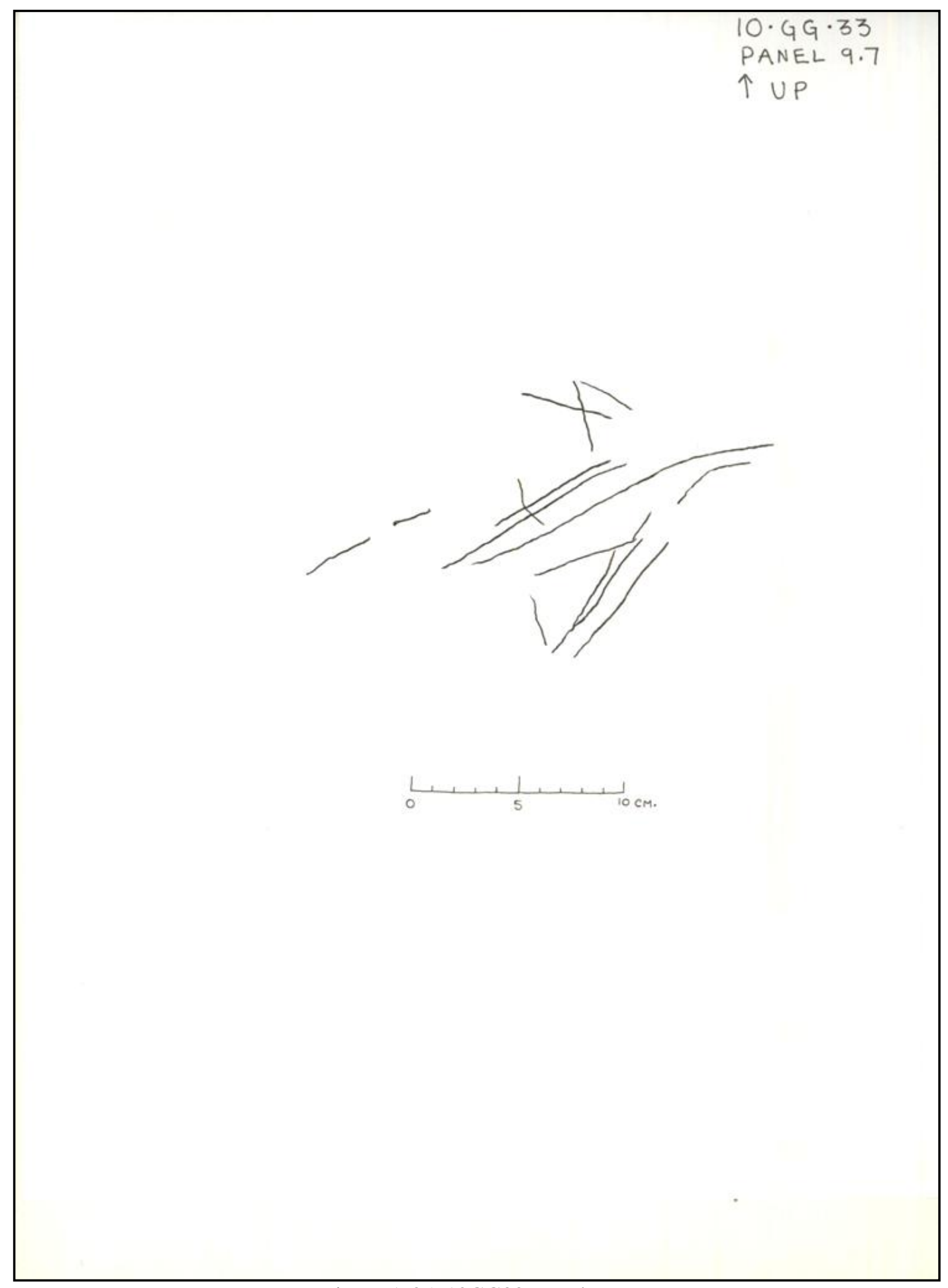

Figure A.35. 10GG33, panel 9.7. 


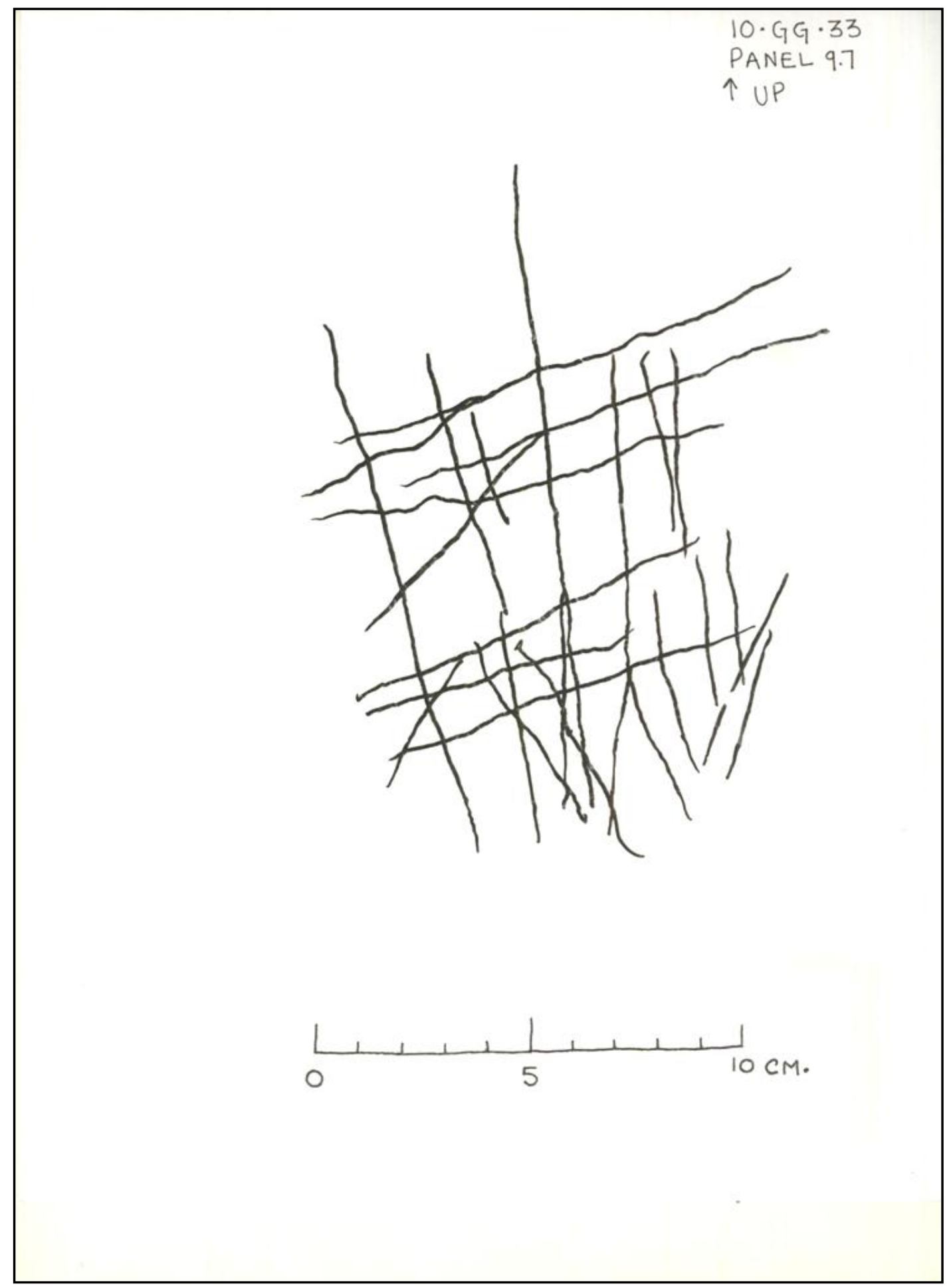

Figure A.36. 10GG33, panel 9.7. 


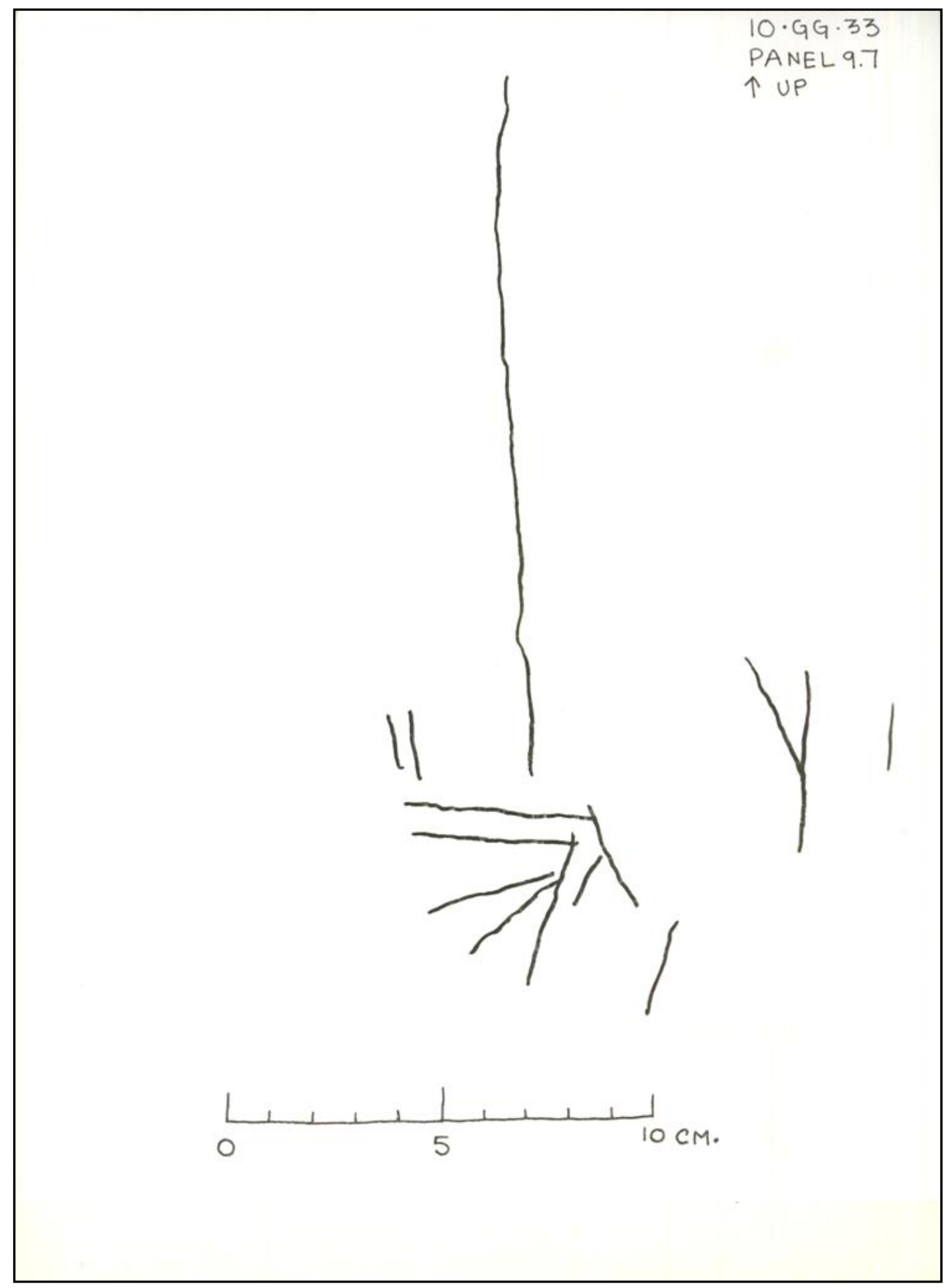

Figure A.37. 10GG33, panel 9.7. 


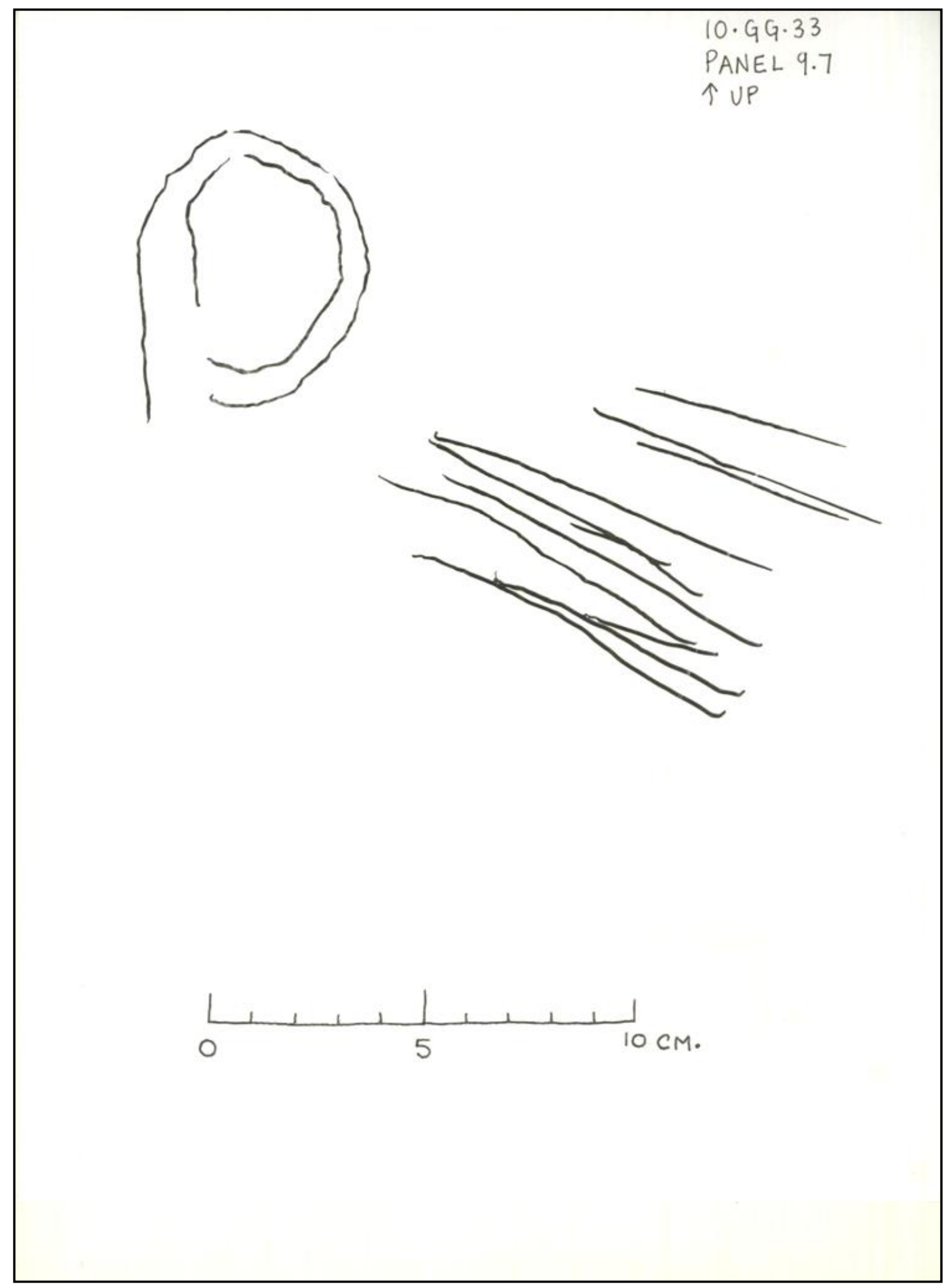

Figure A.38. 10GG33, panel 9.7. 


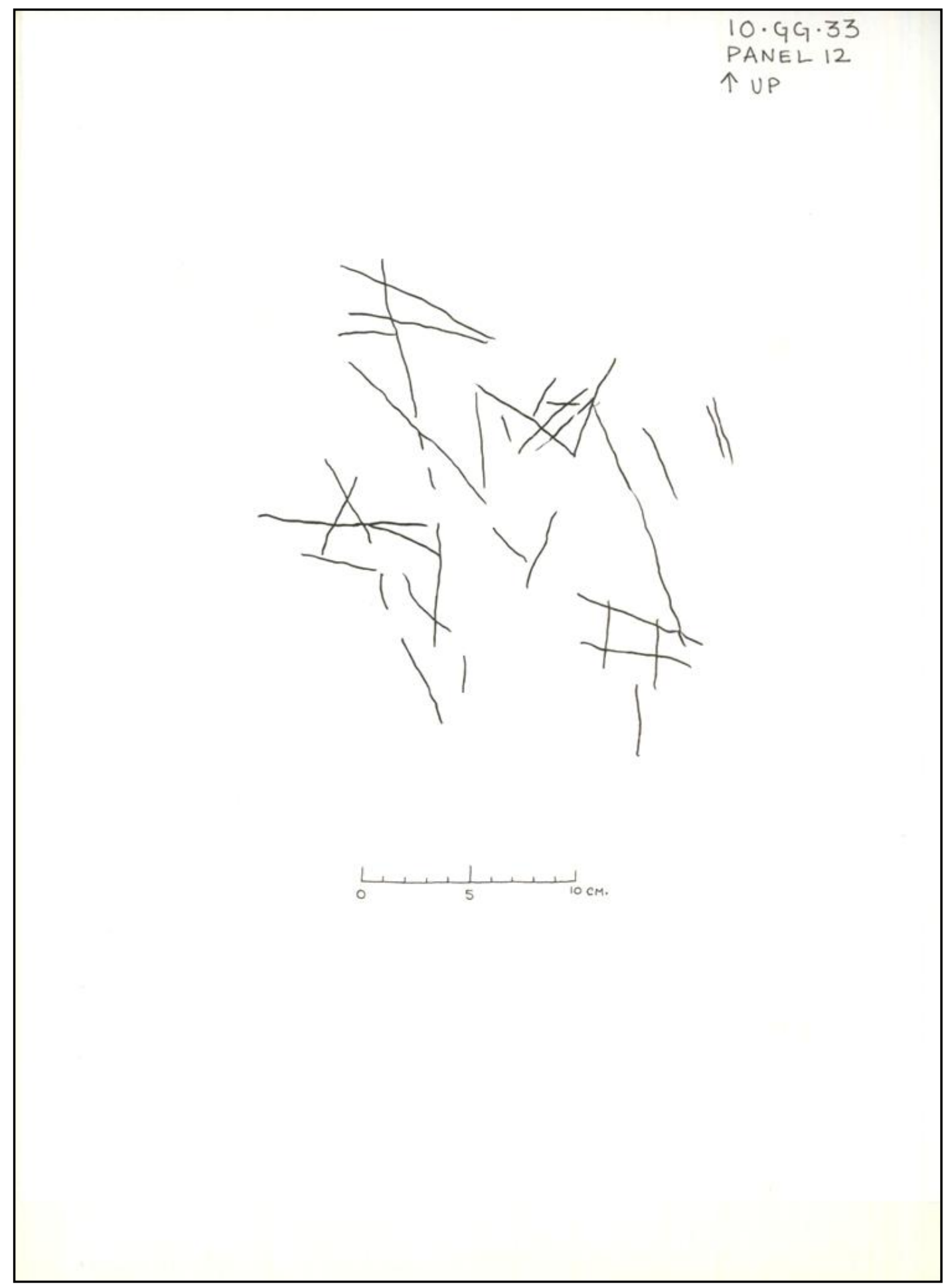

Figure A.39. 10GG33, panel 12. 


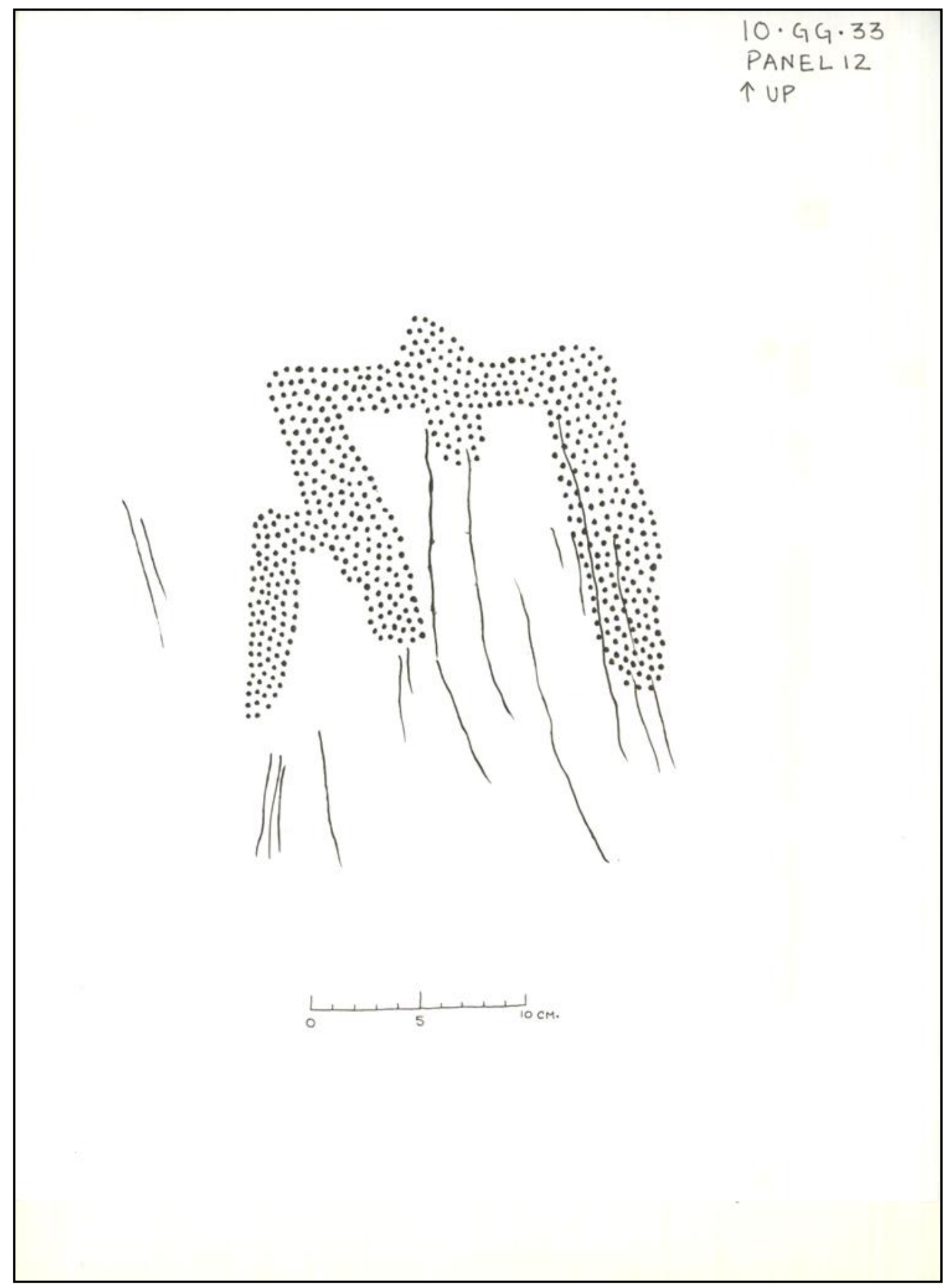

Figure A.40. 10GG33, panel 12. 


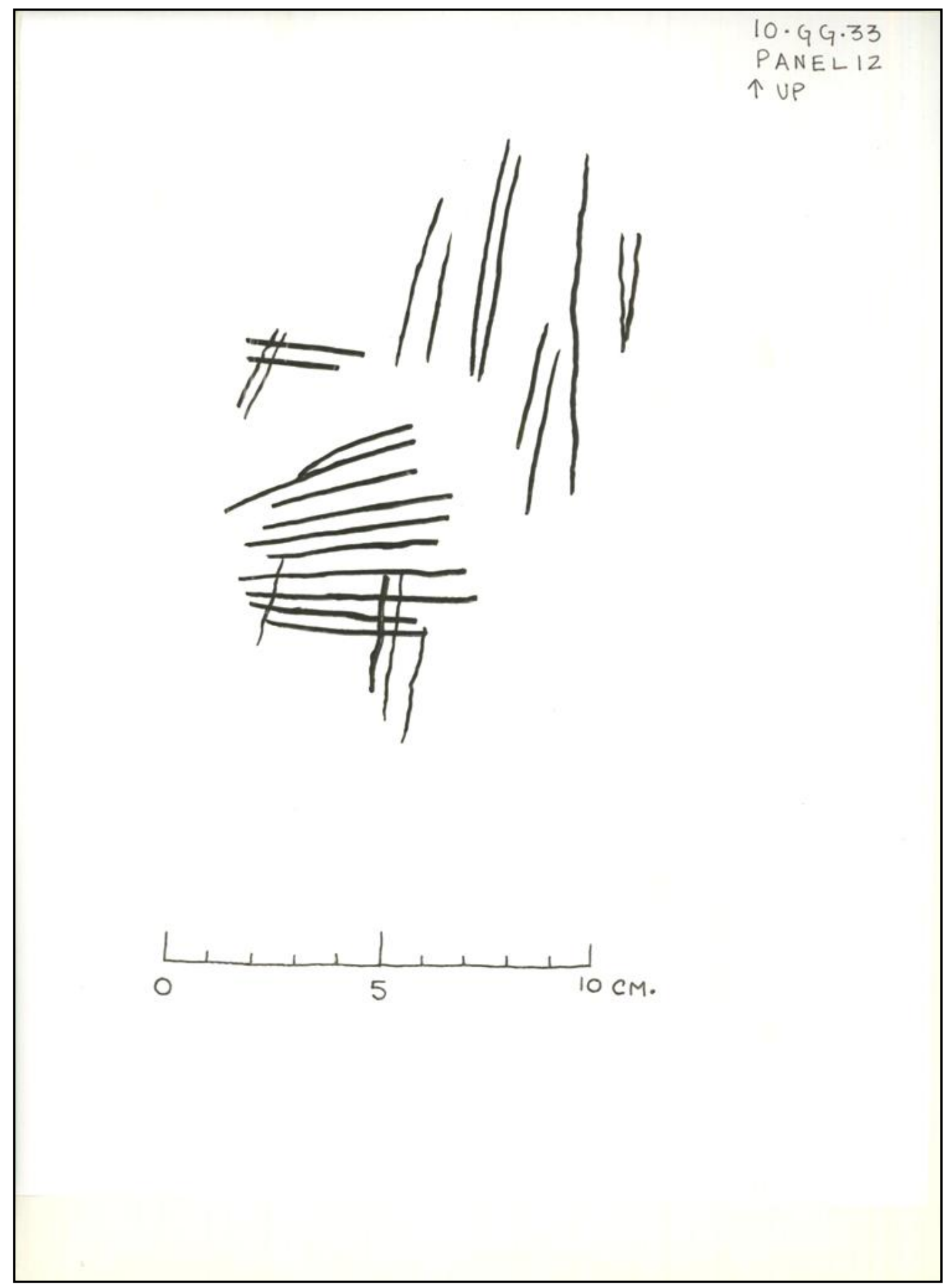

Figure A.41. 10GG33, panel 12. 


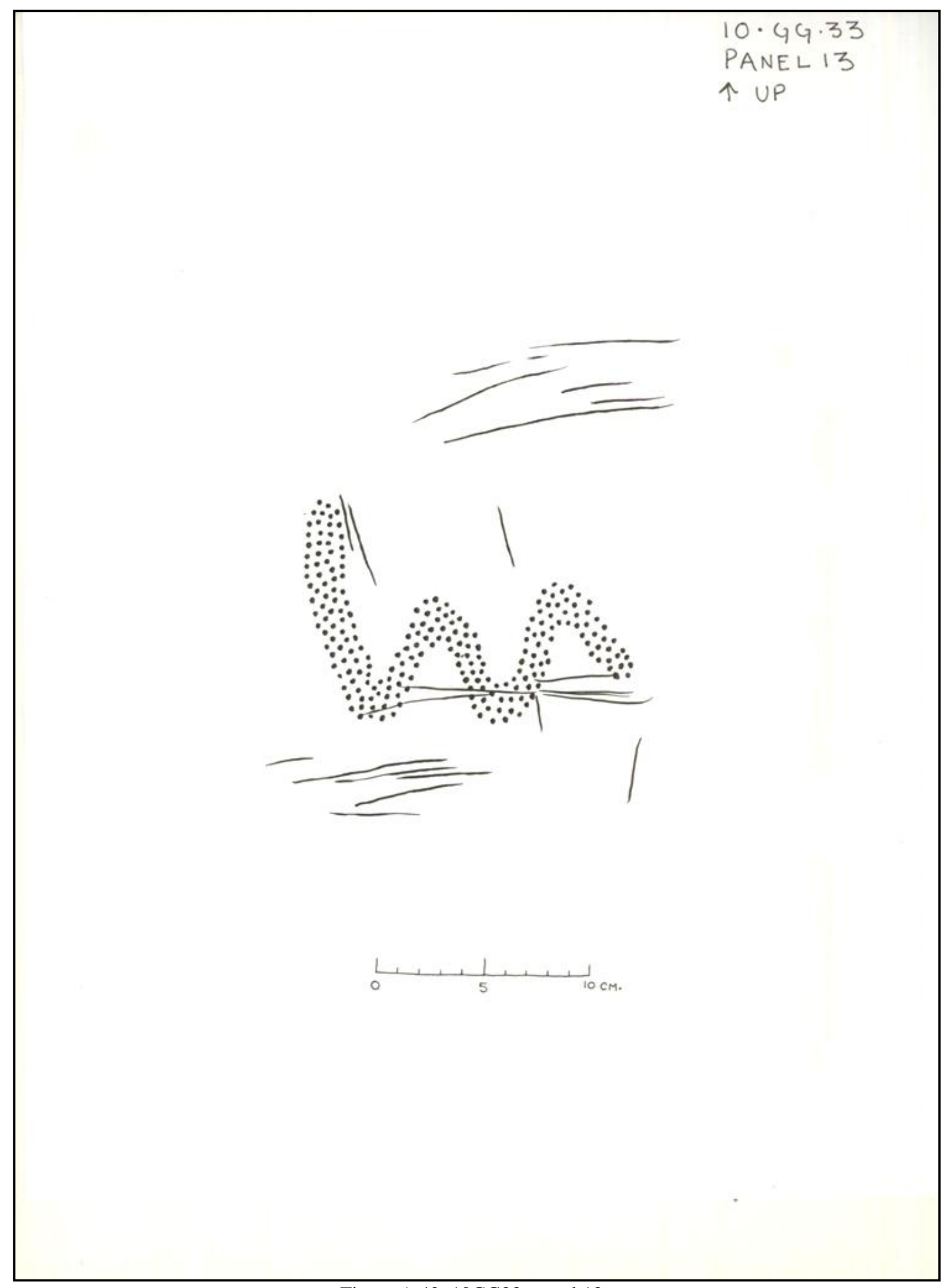

Figure A.42. 10GG33, panel 13. 


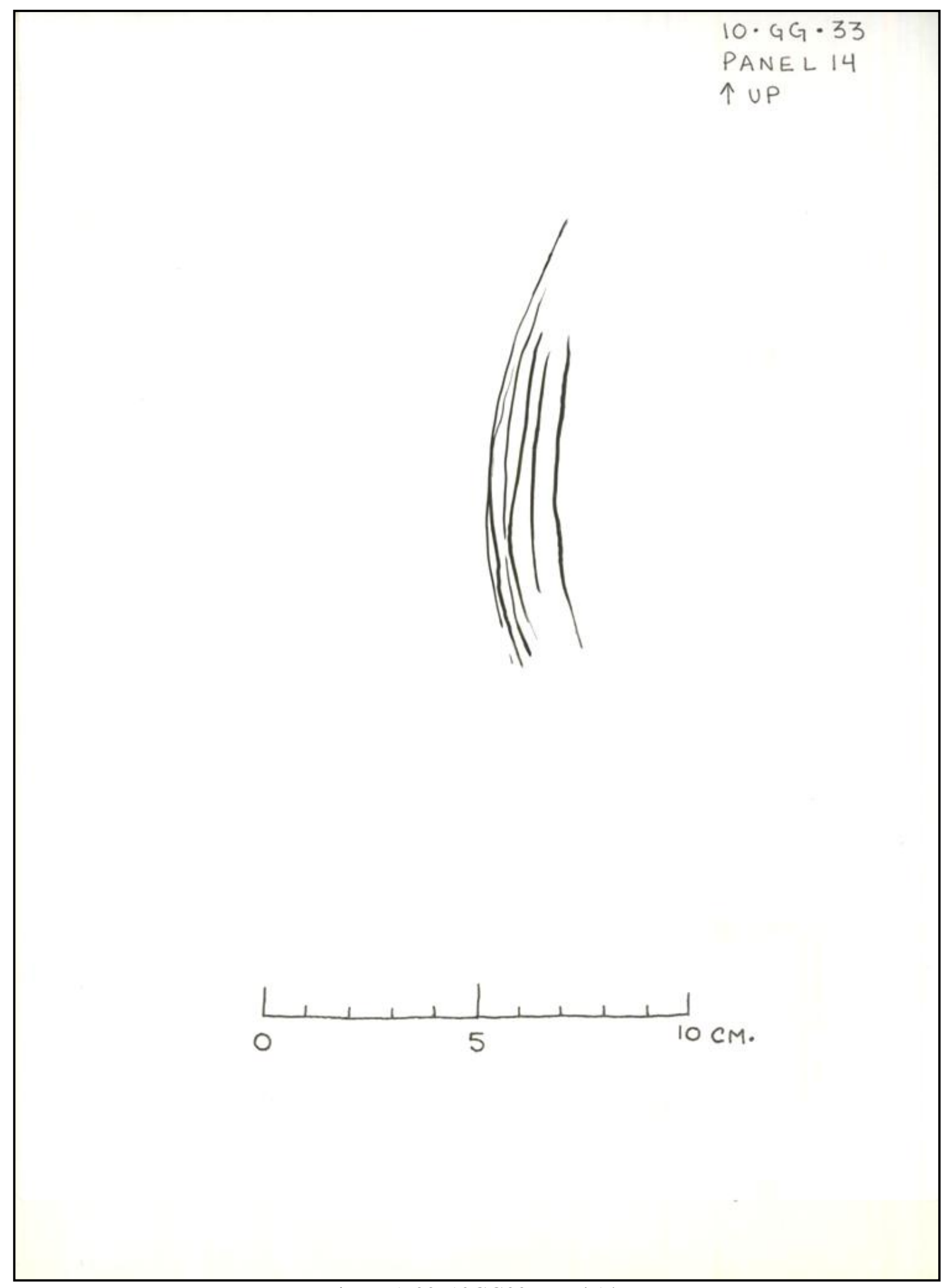

Figure A.33. 10GG33, panel 14. 


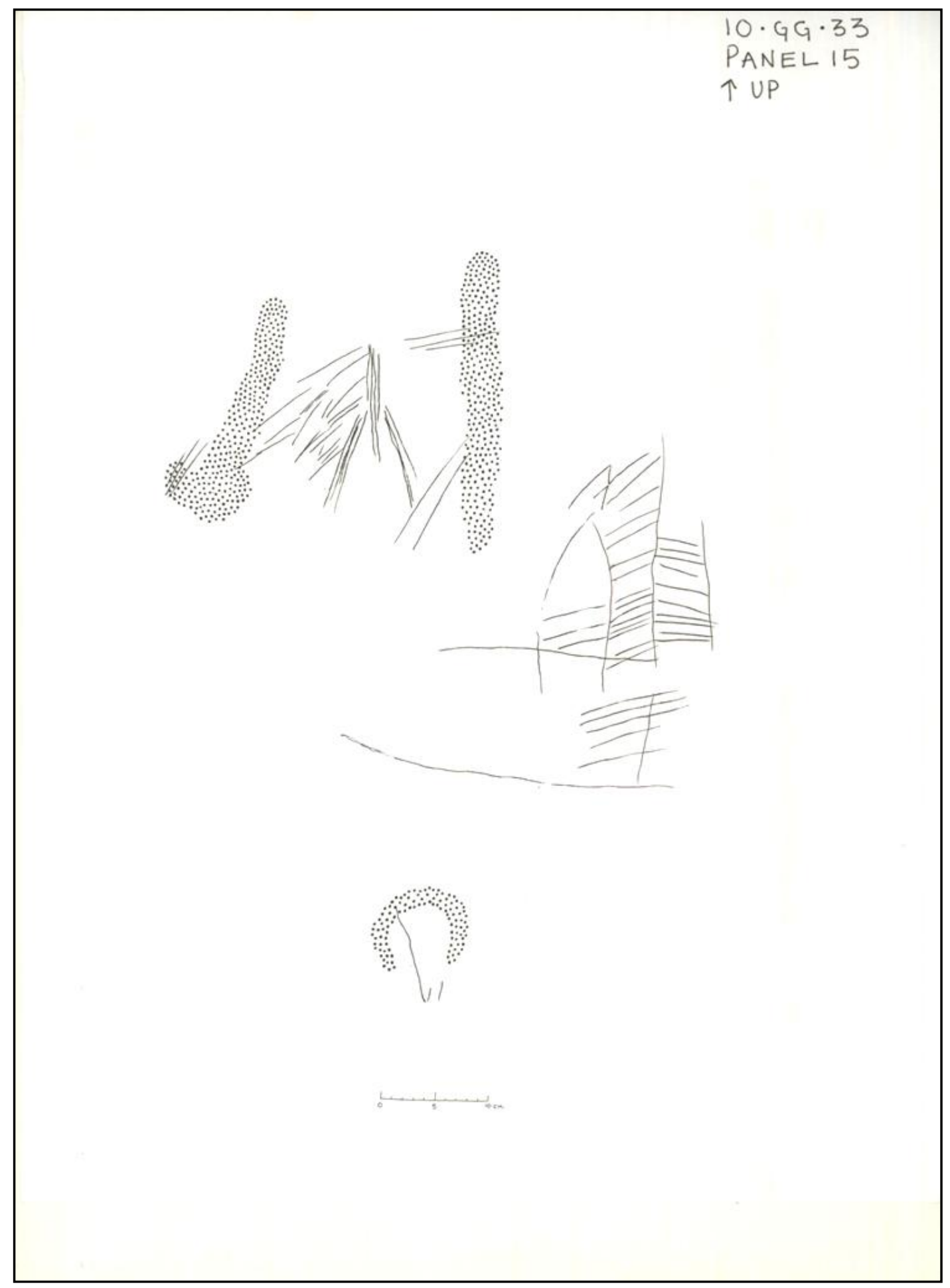

Figure A.44. 10GG33, panel 15. 


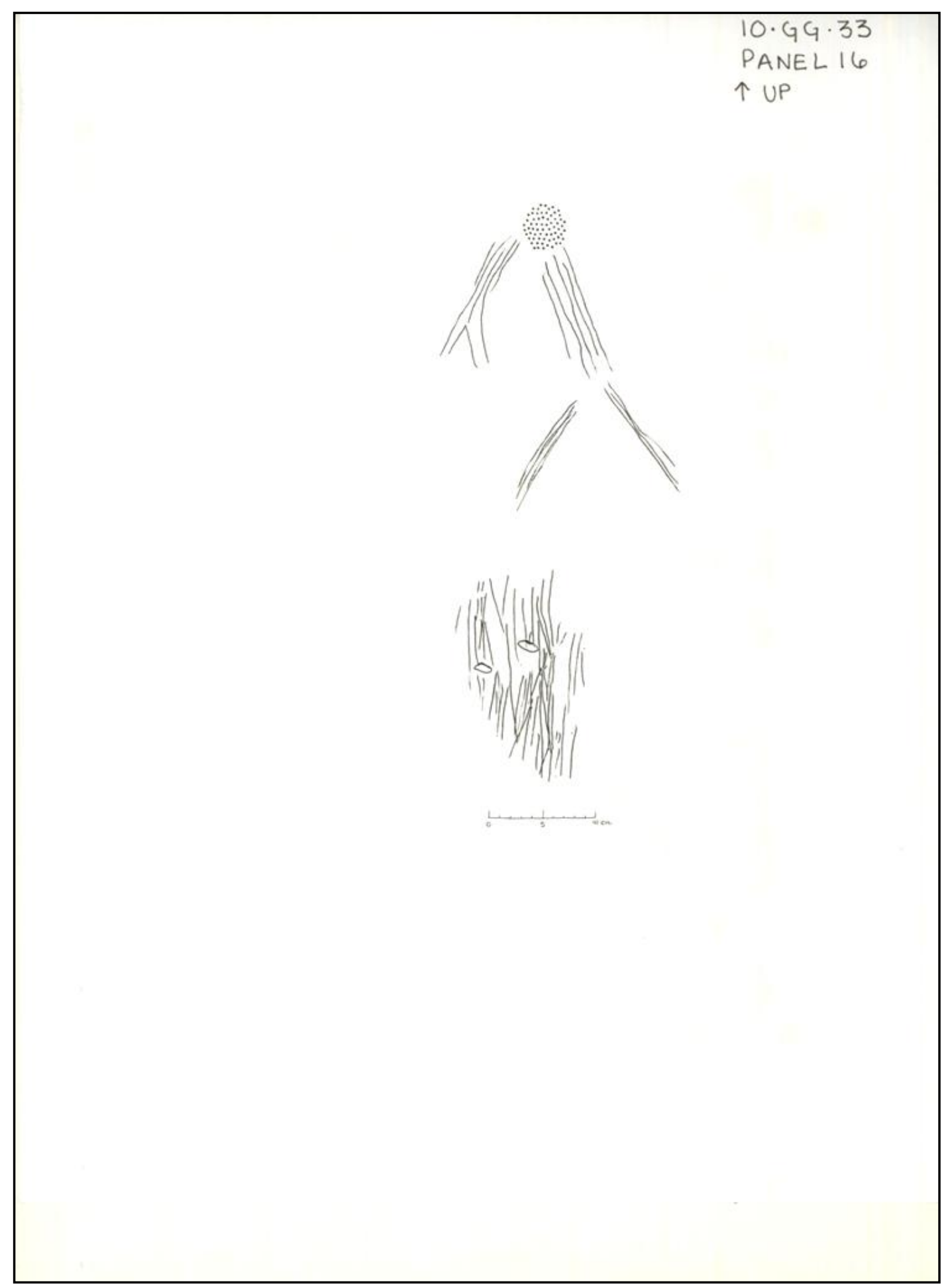

Figure A.45. 10GG33, panel 16. 


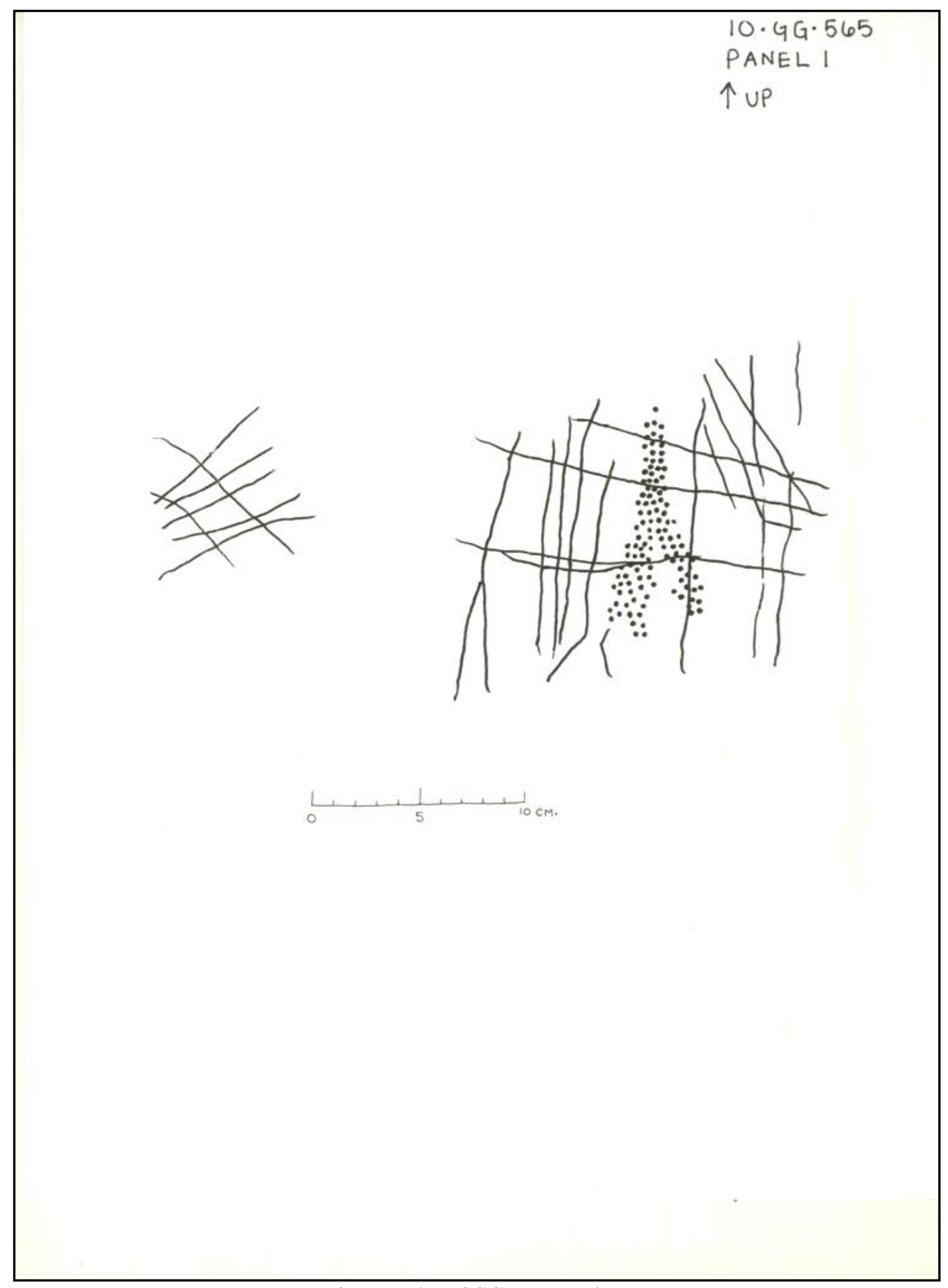

Figure A.46. 10GG565, panel 1. 


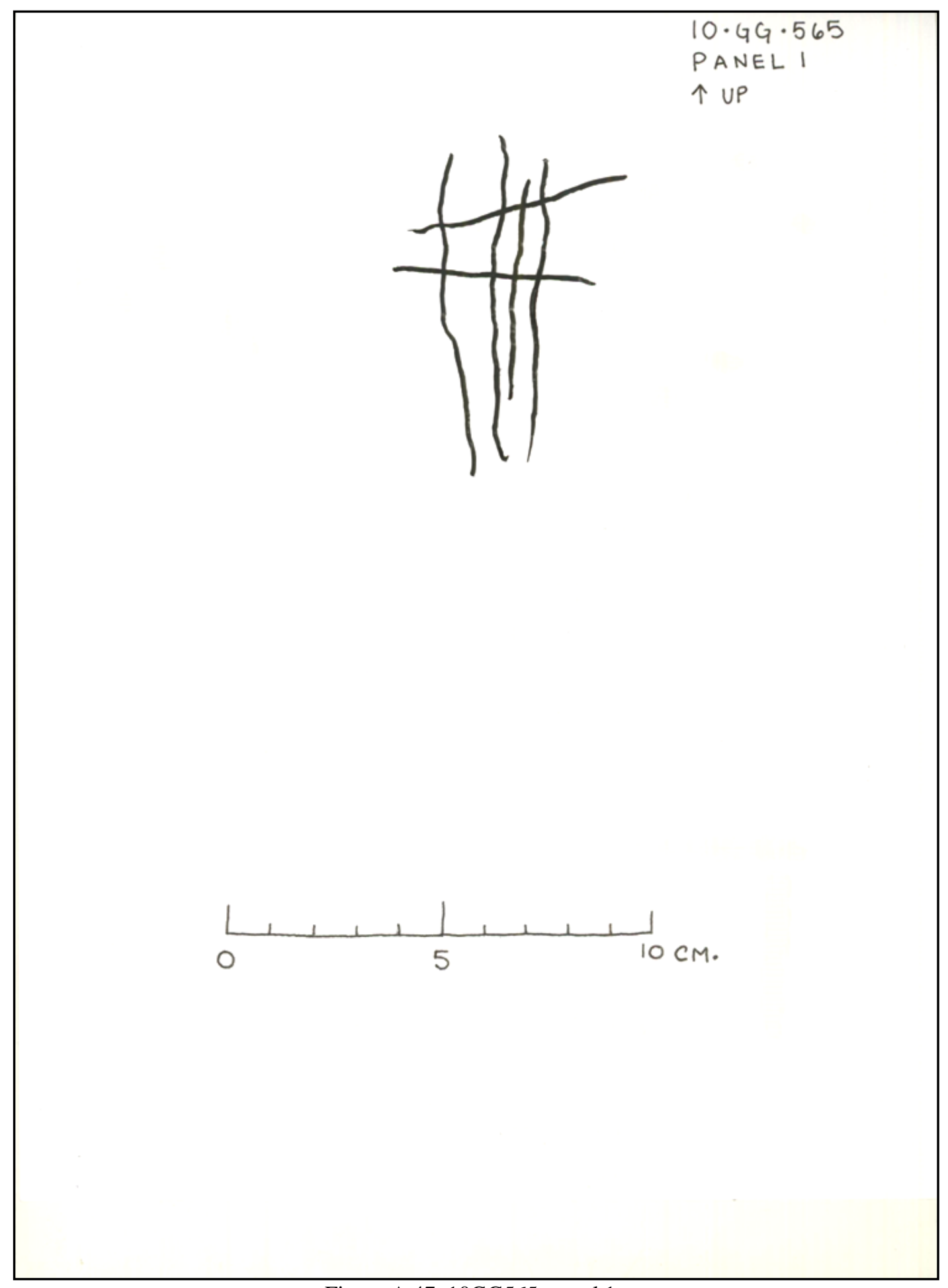

Figure A.47. 10GG565, panel 1.

179 


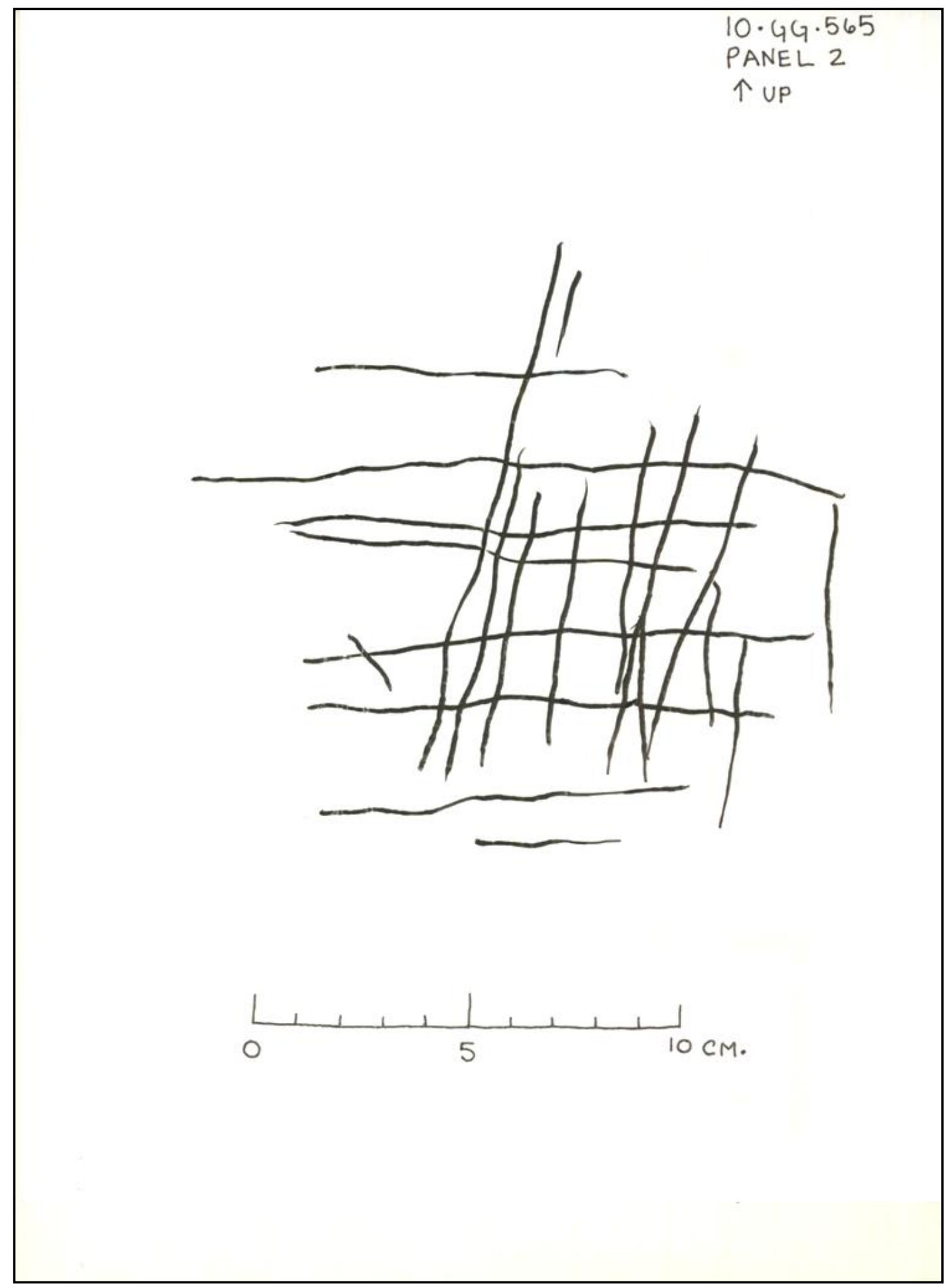

Figure A.48. 10GG565, panel 2. 


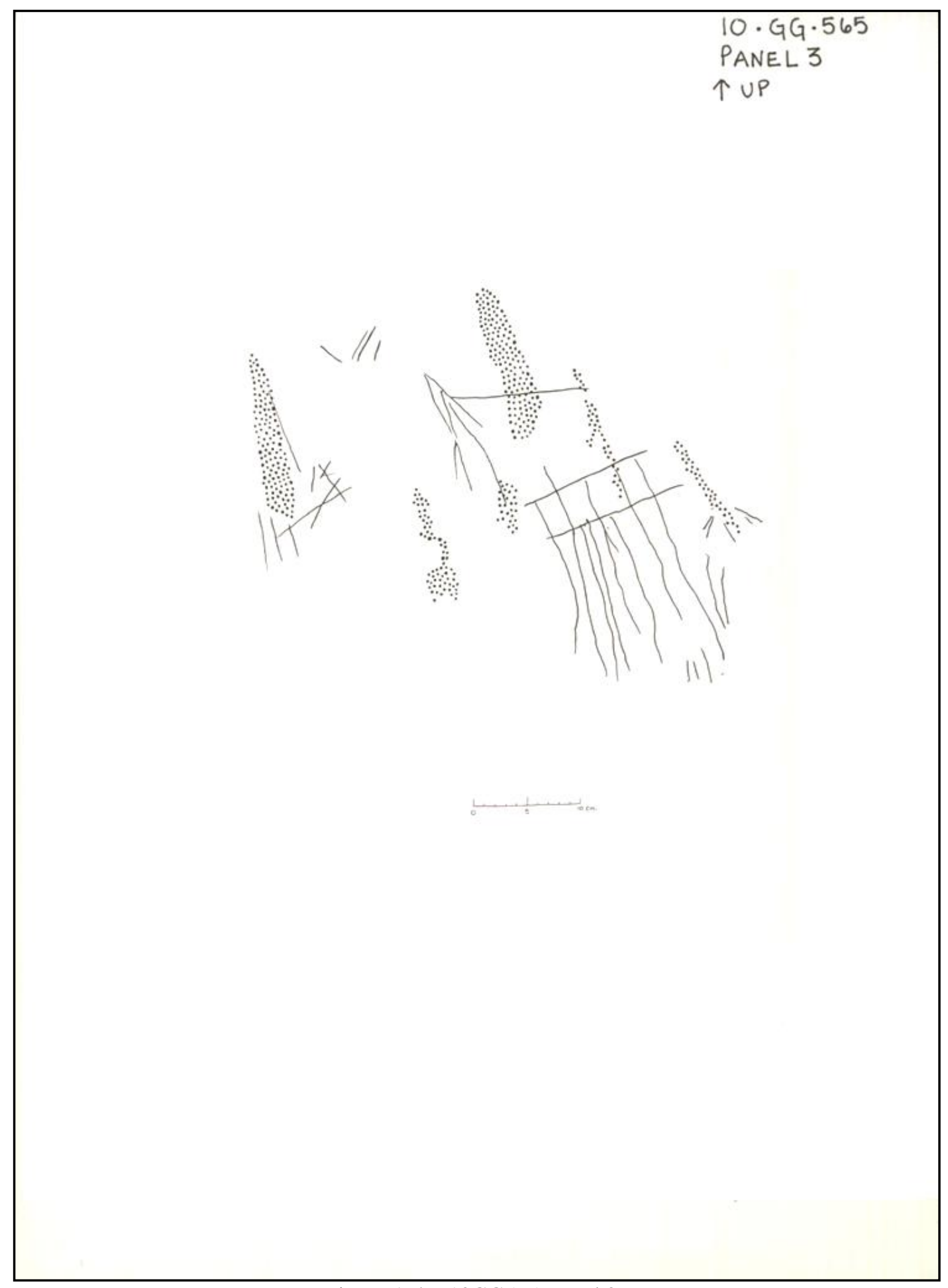

Figure A.49. 10GG565, panel 3. 


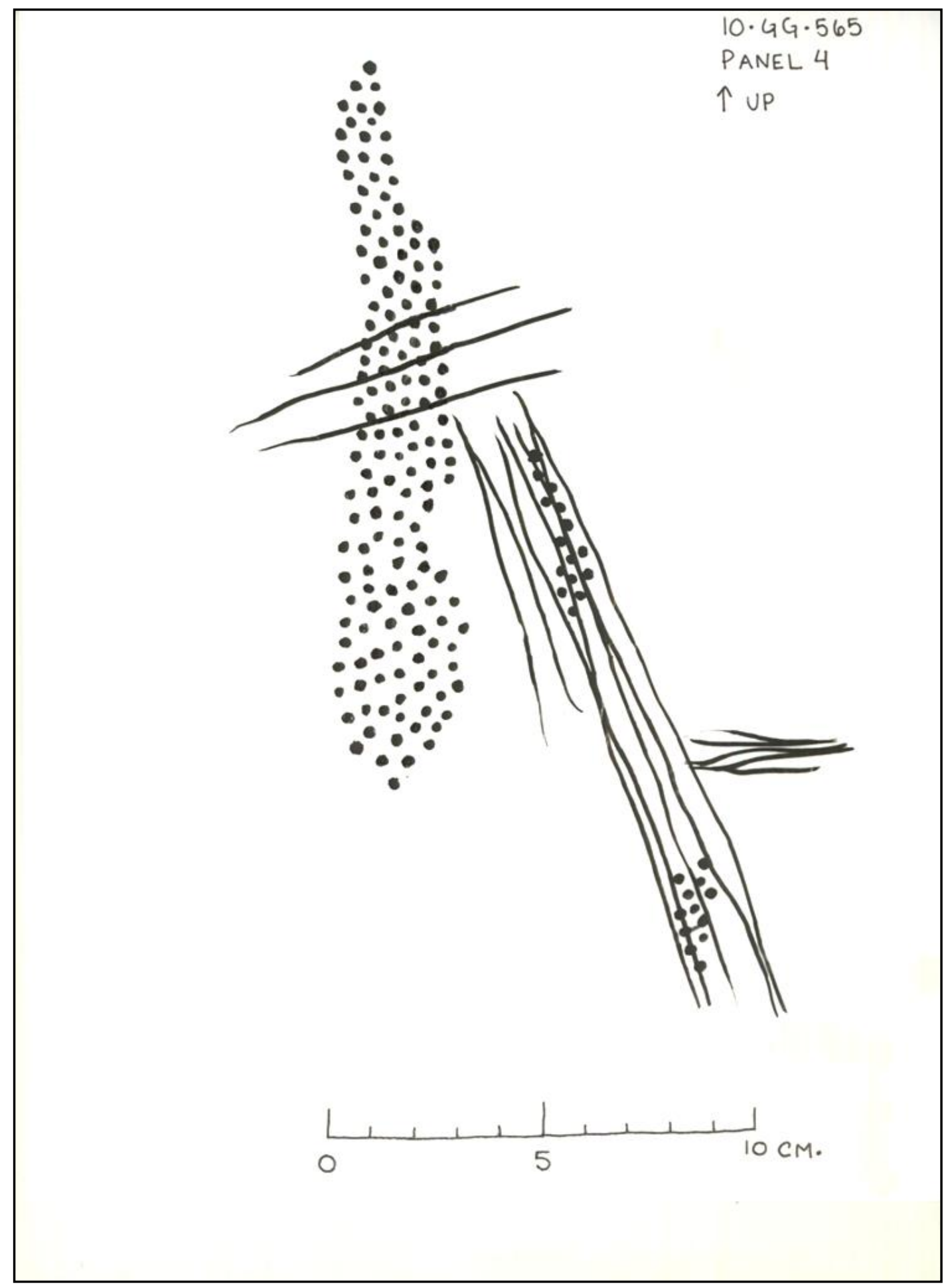

Figure A.50. 10GG565, panel 4. 


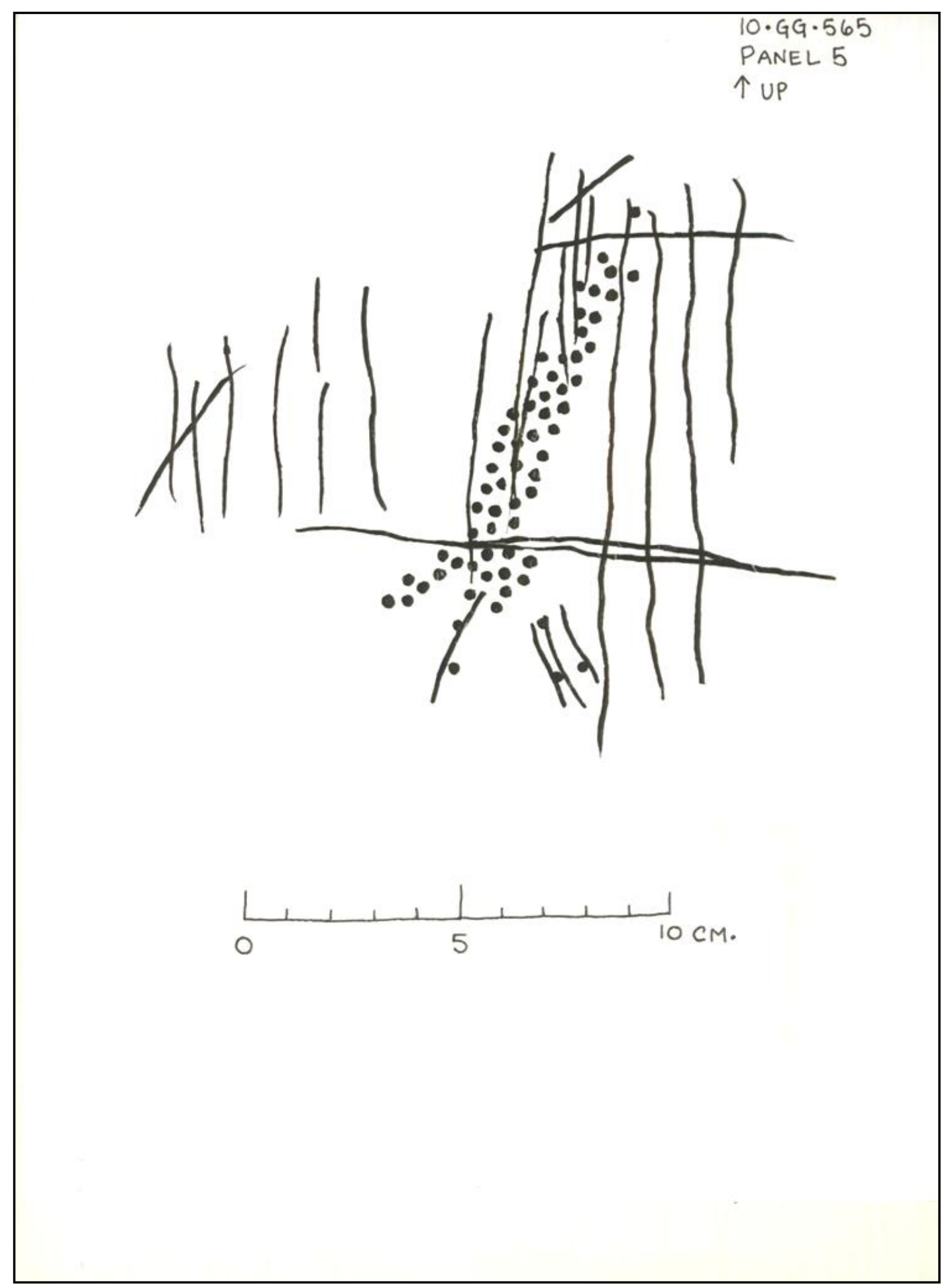

Figure A.51. 10GG565, panel 5. 


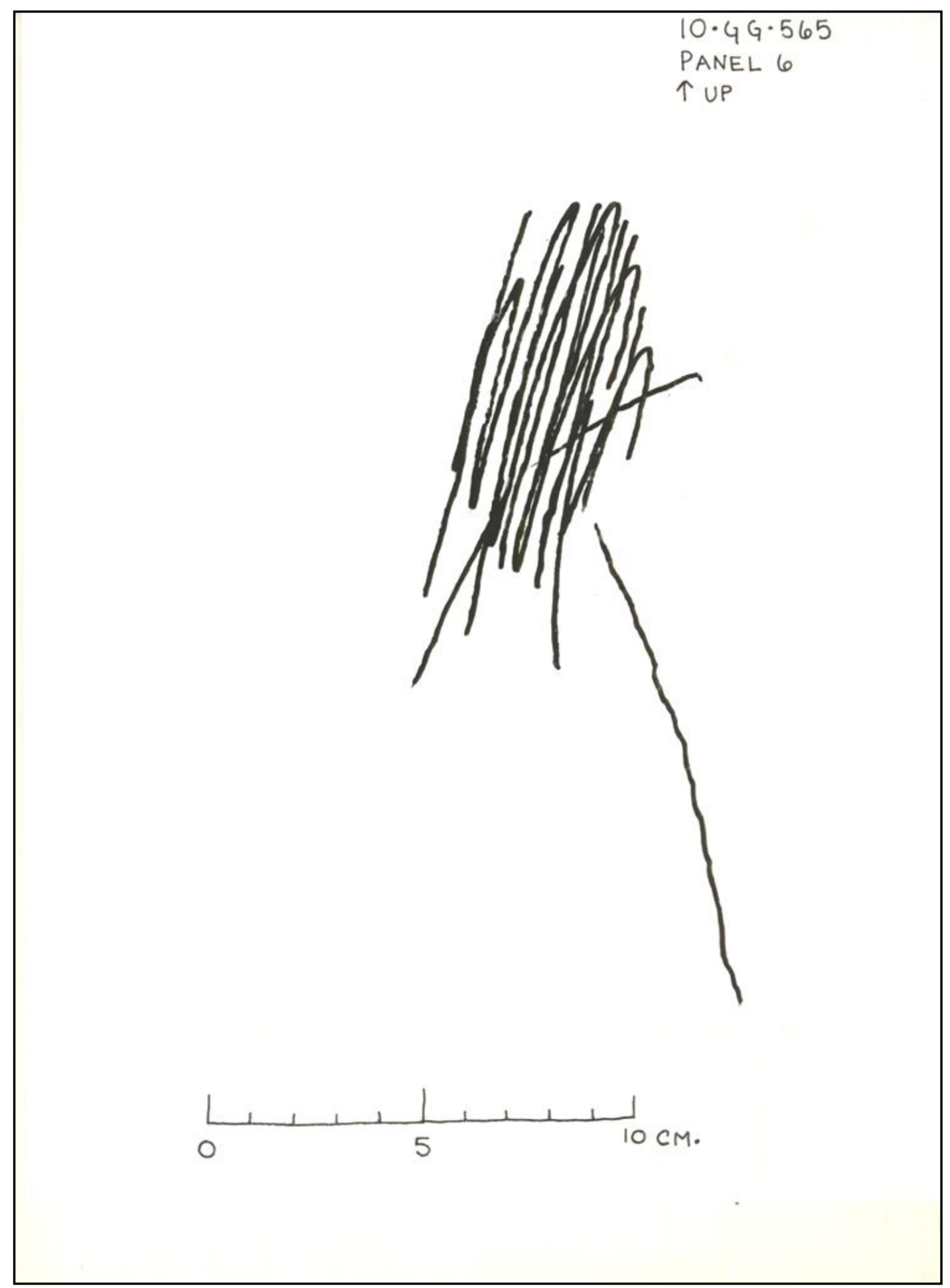

Figure A.52. 10GG565, panel 6. 


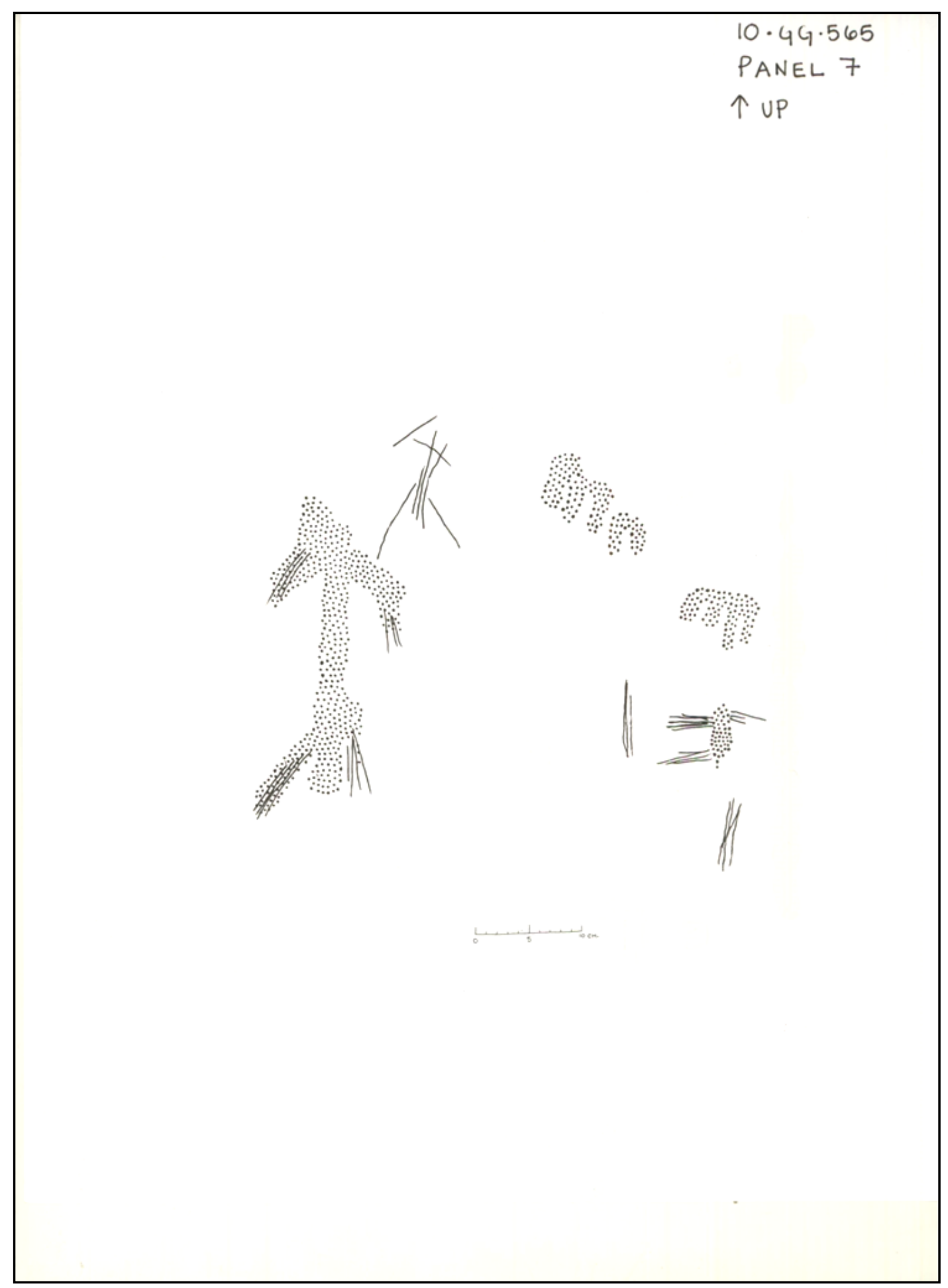

Figure A.53. 10GG565, panel 7. 


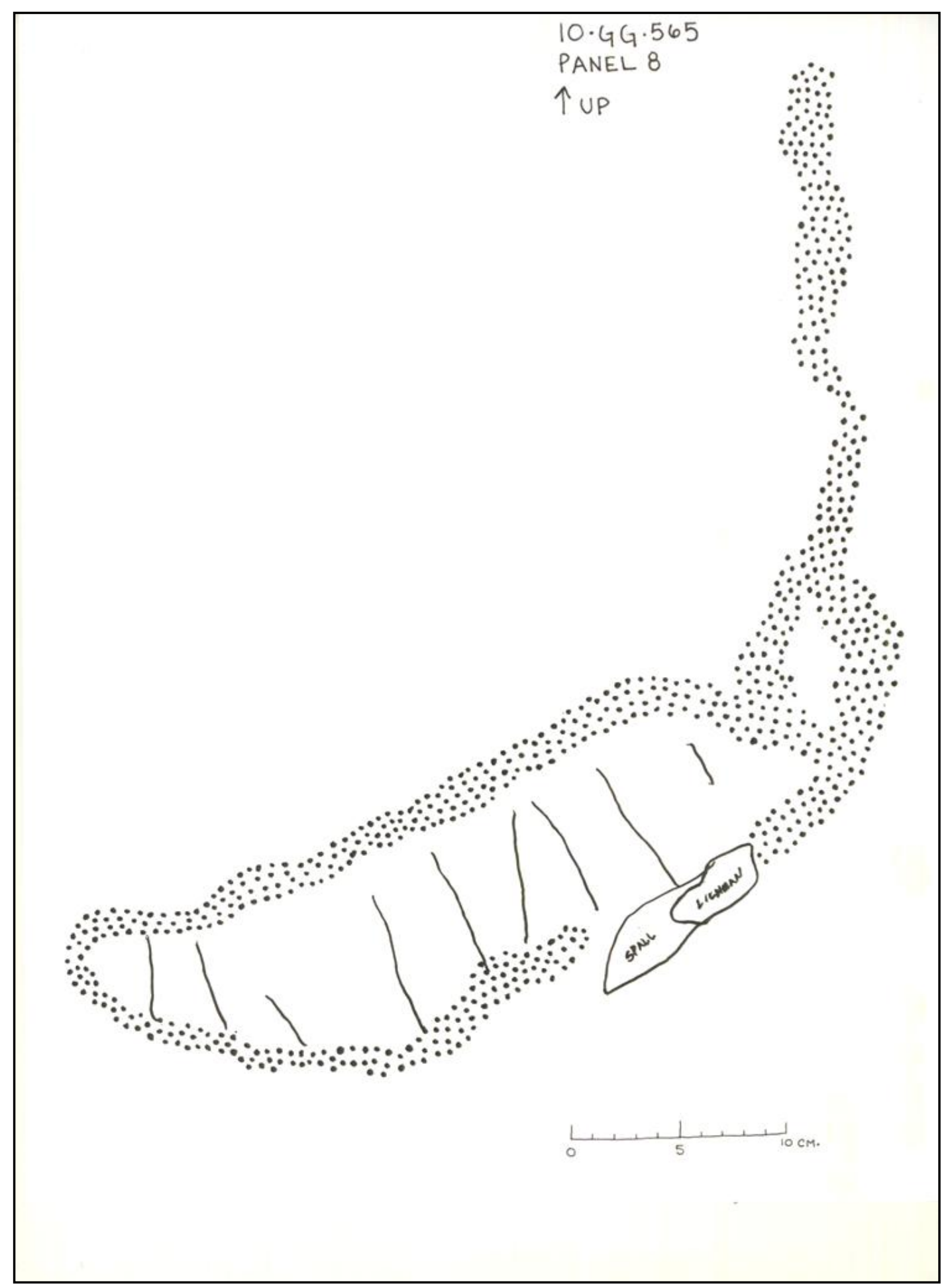

Figure A.54. 10GG565, panel 8. 


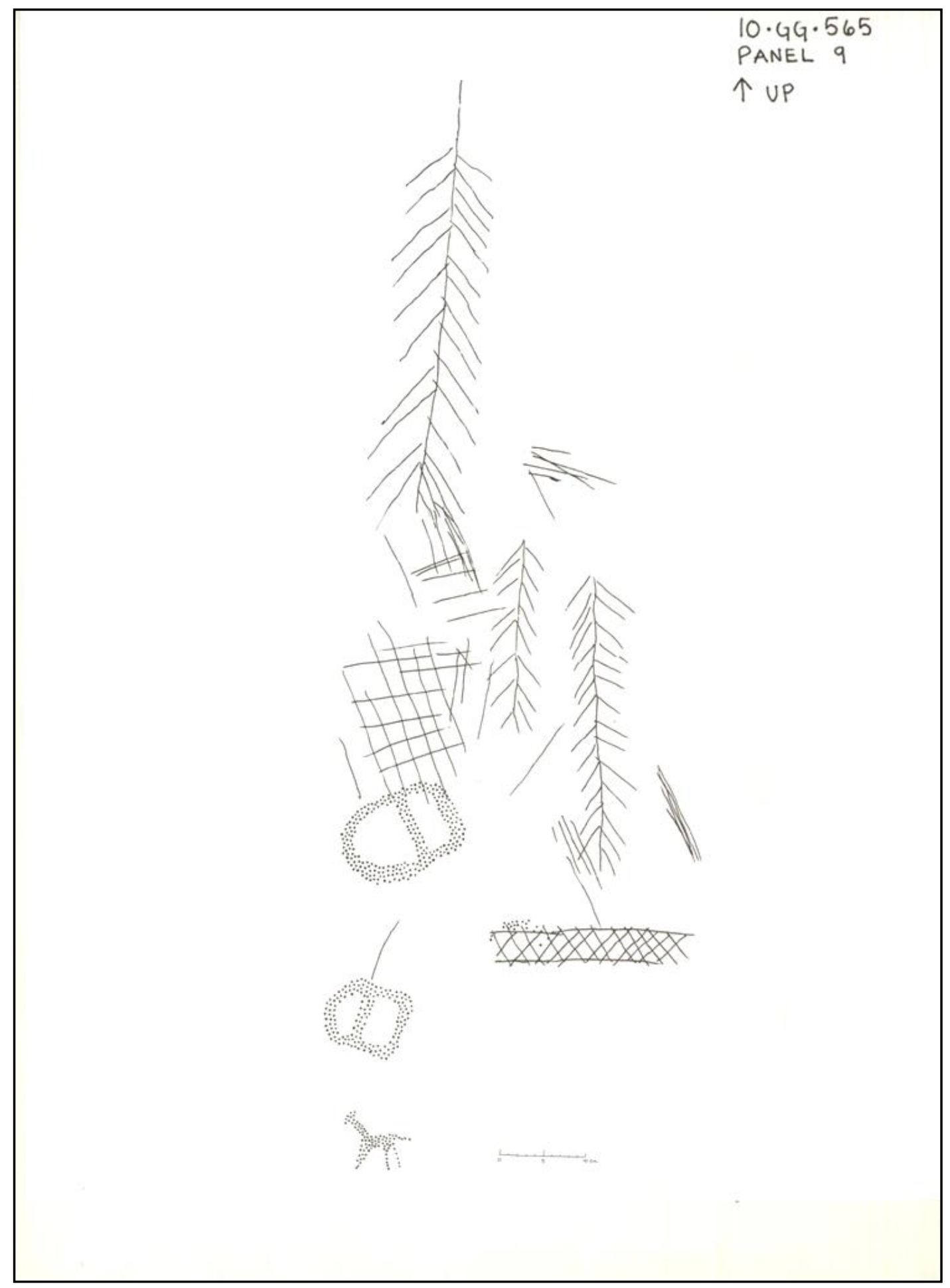

Figure A.55. 10GG565, panel 9. 


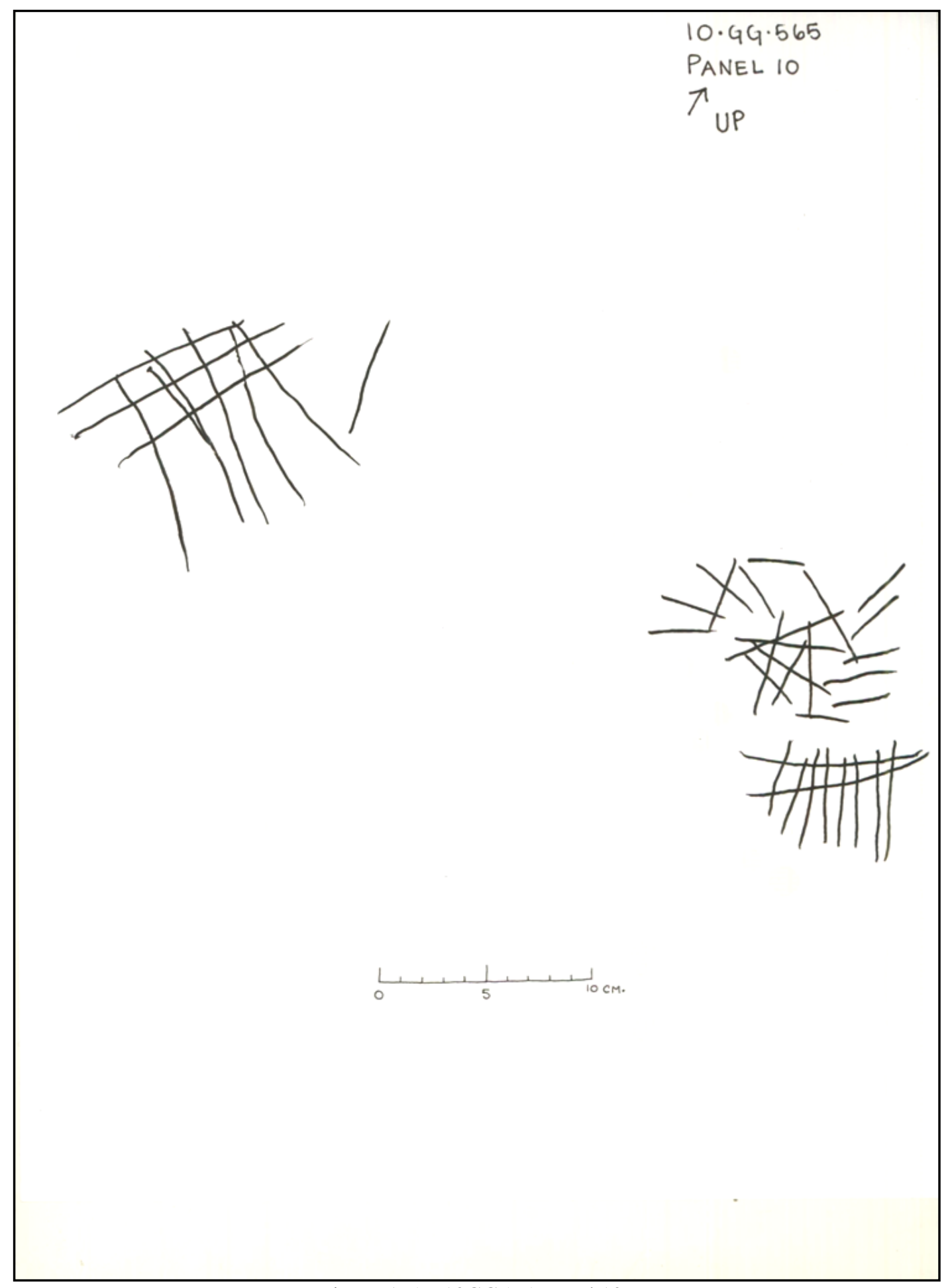

Figure A.56. 10GG565, panel 10. 


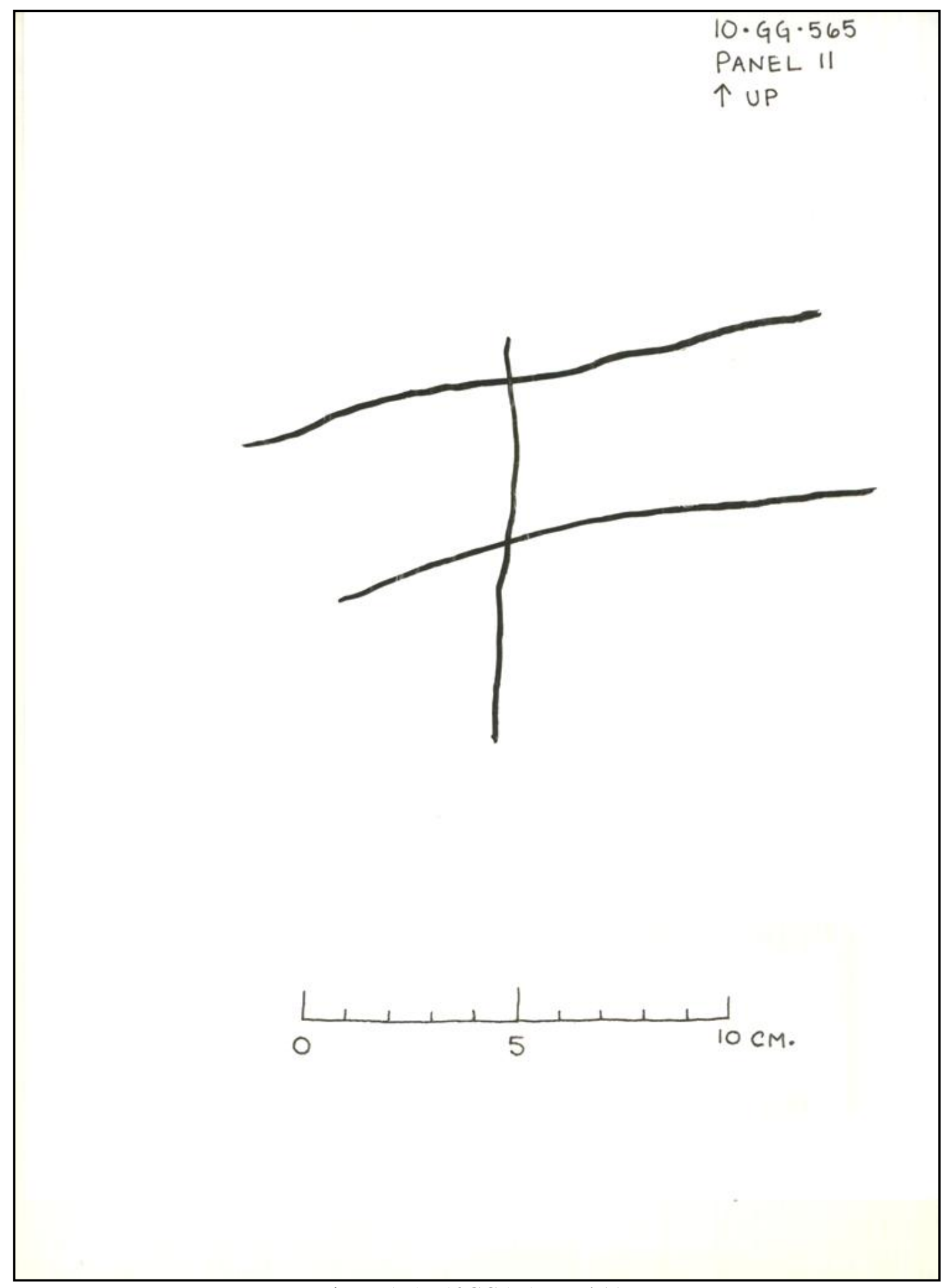

Figure A.57. 10GG565, panel 11. 


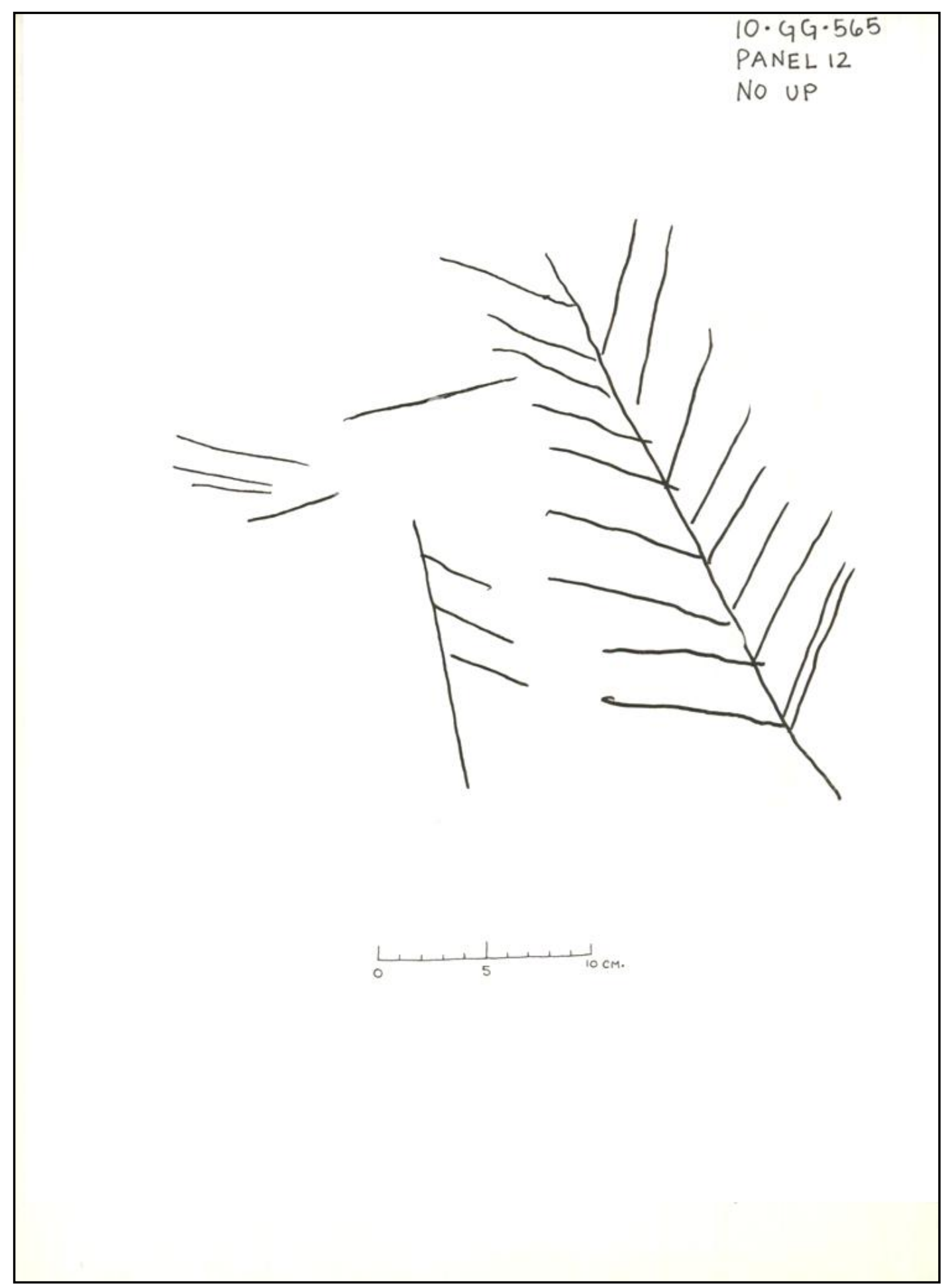

Figure A.58. 10GG565, panel 12. 


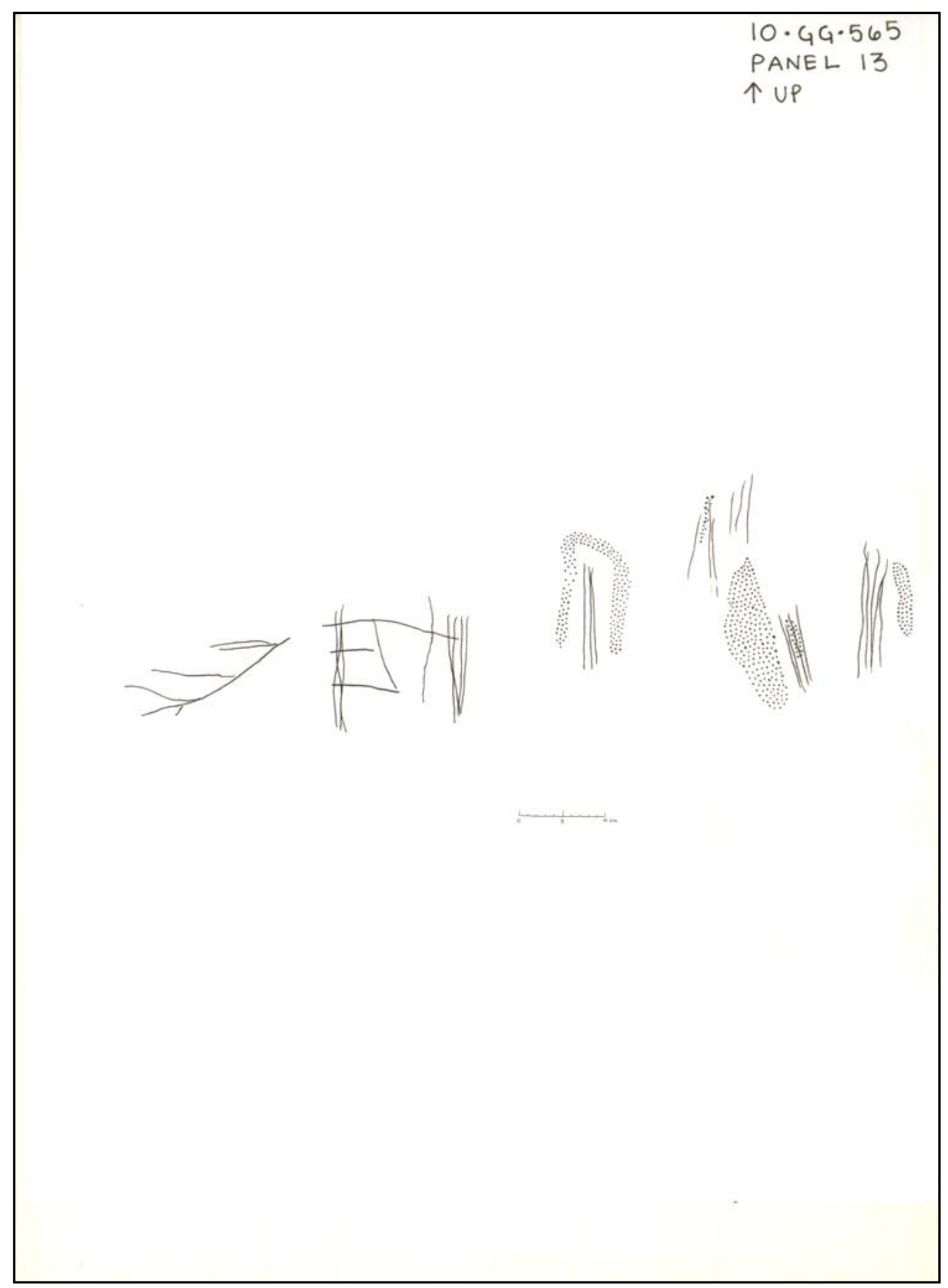

Figure A.59. 10GG565, panel 13. 


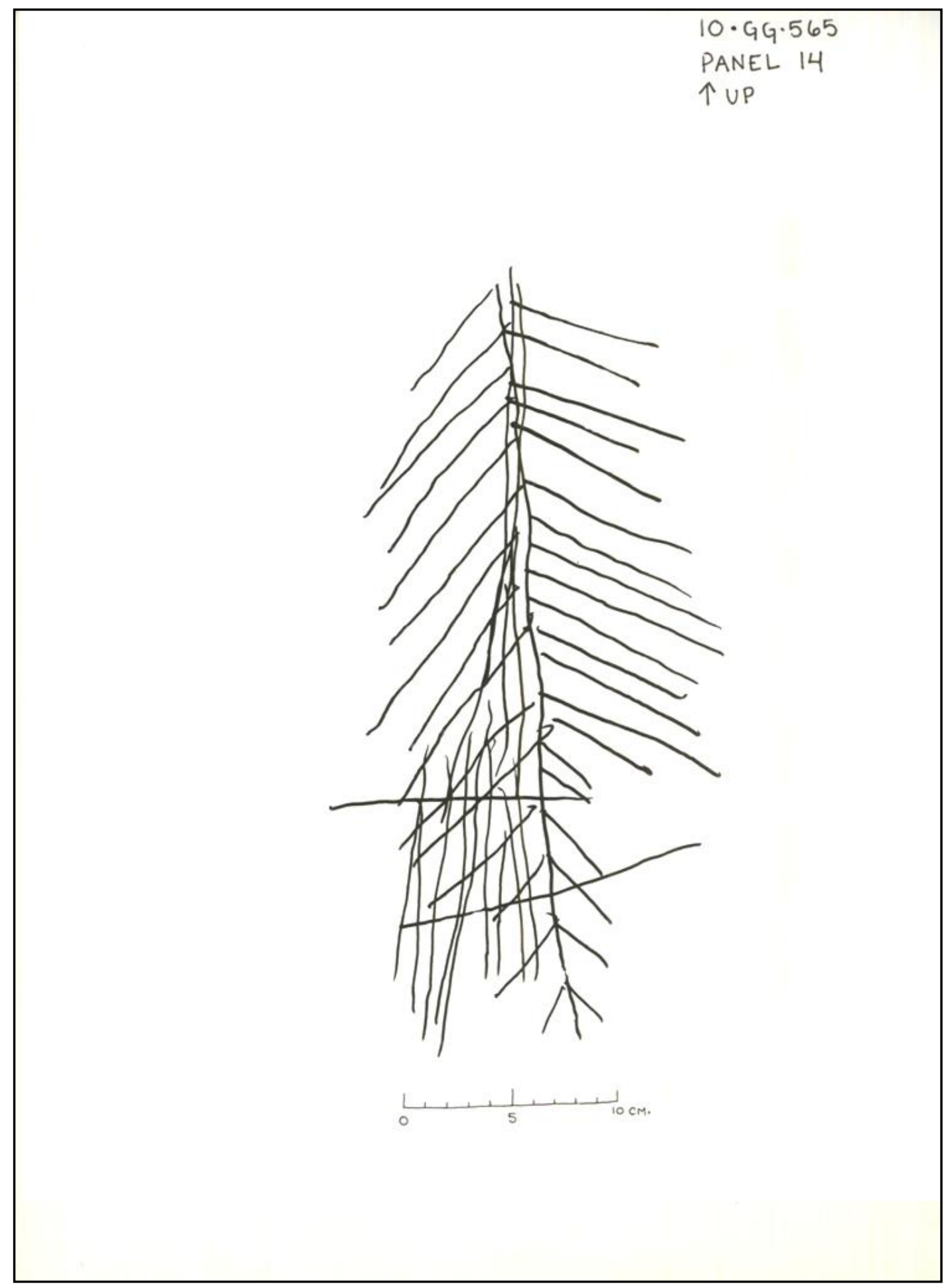

Figure A.60. 10GG565, panel 14. 


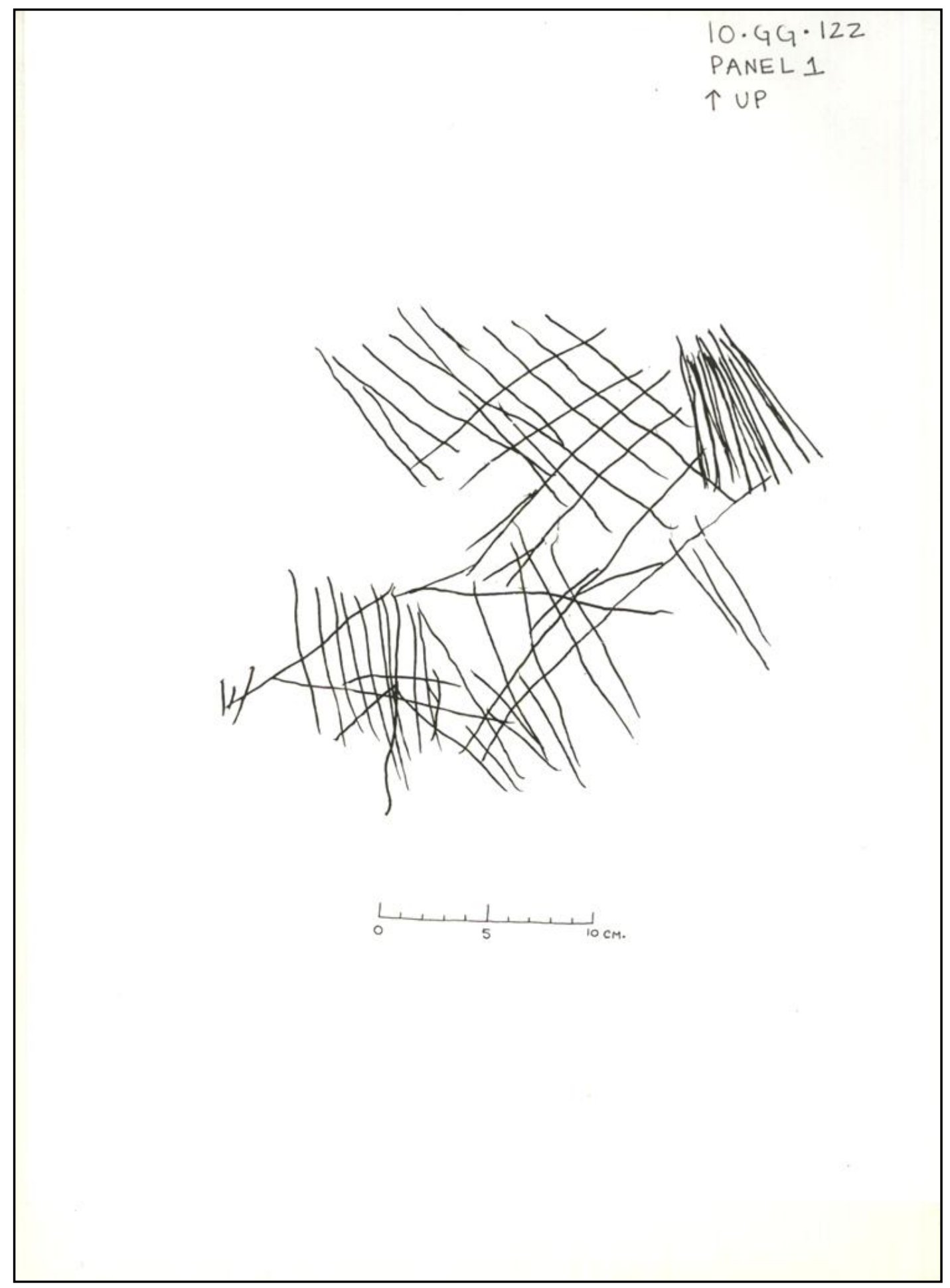

Figure A.61. 10GG122, panel 1. 


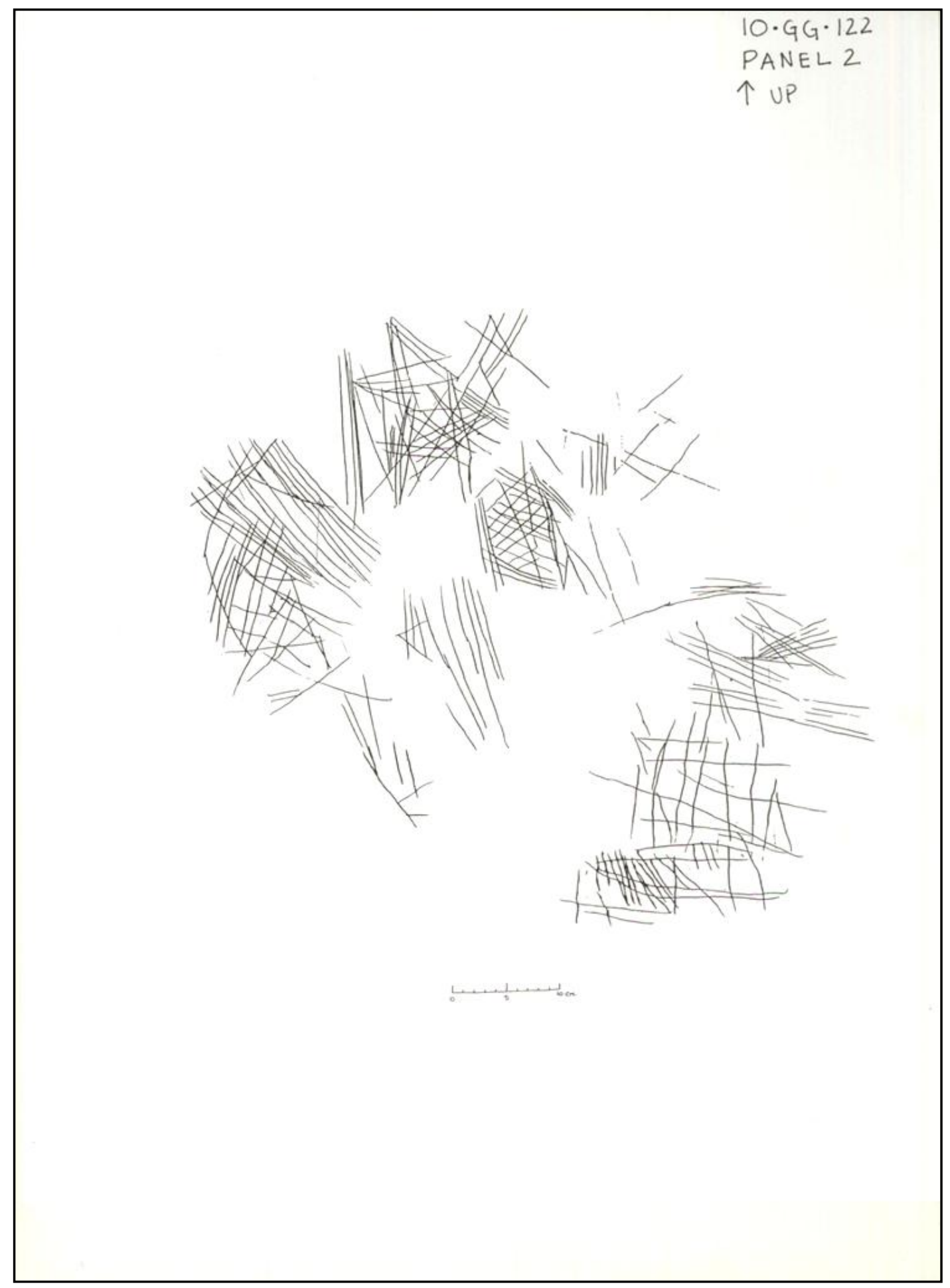

Figure A.62. 10GG122, panel 2. 


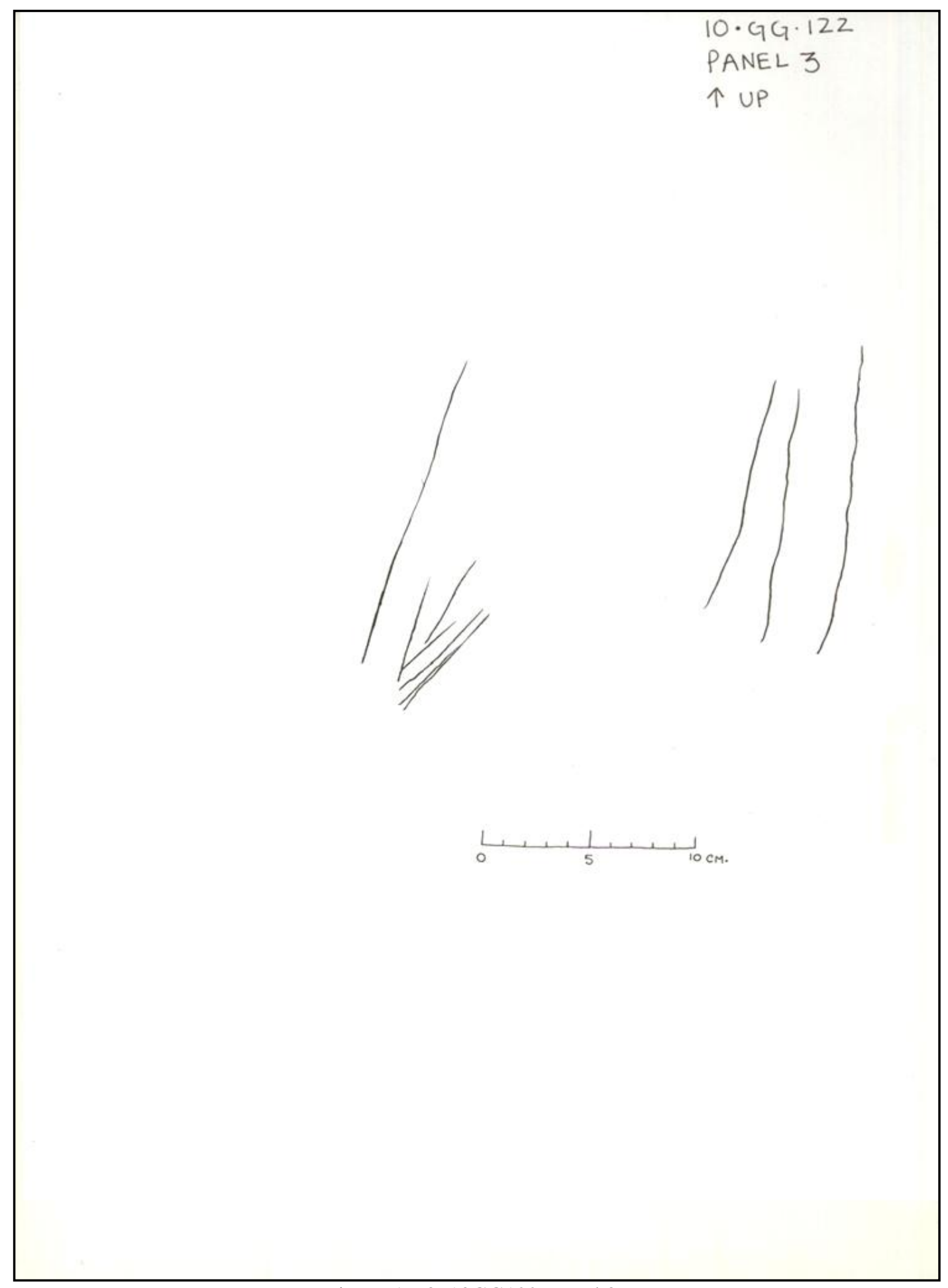

Figure A.63. 10GG122, panel 3. 


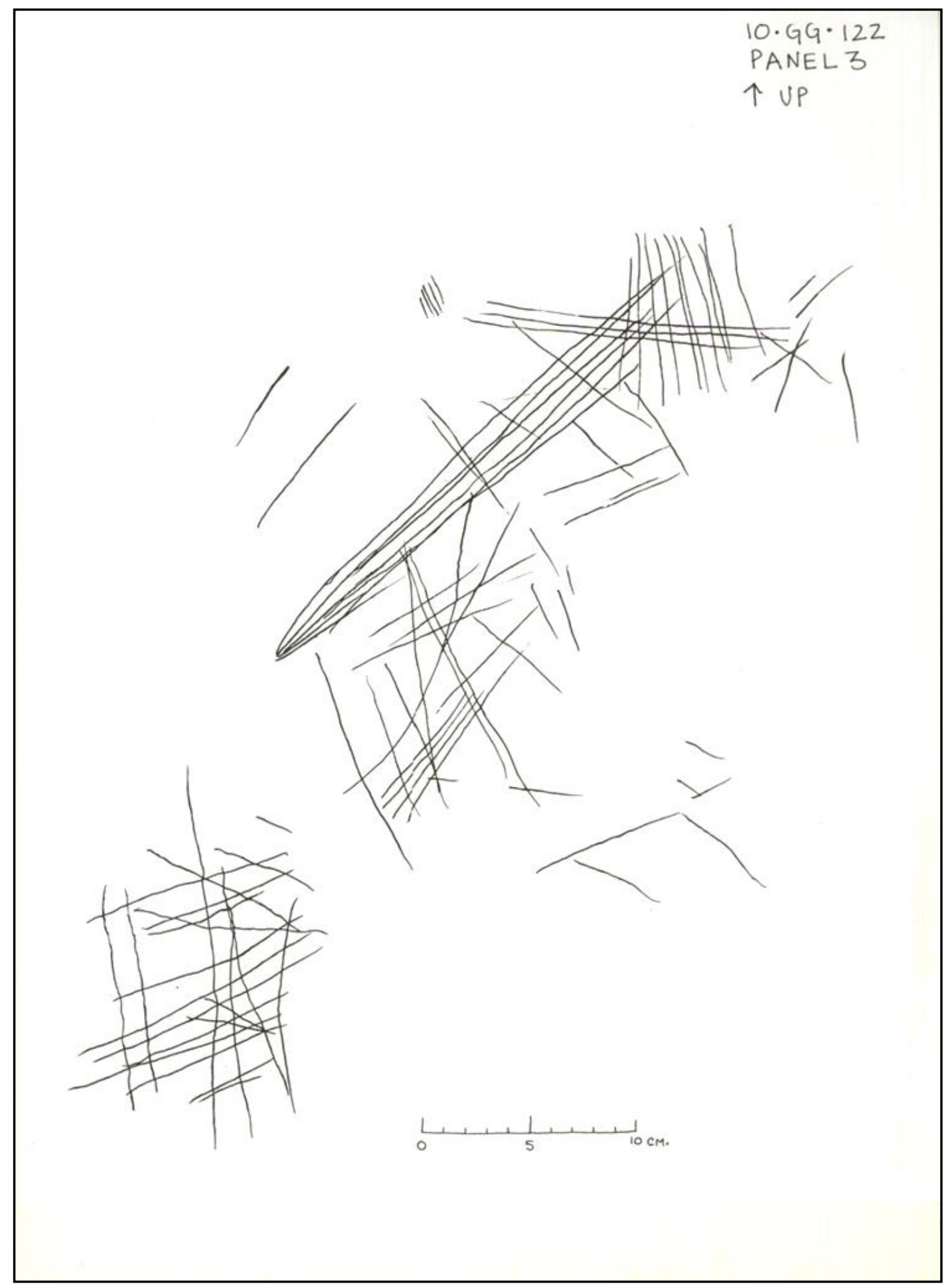

Figure A.64. 10GG122, panel 3. 


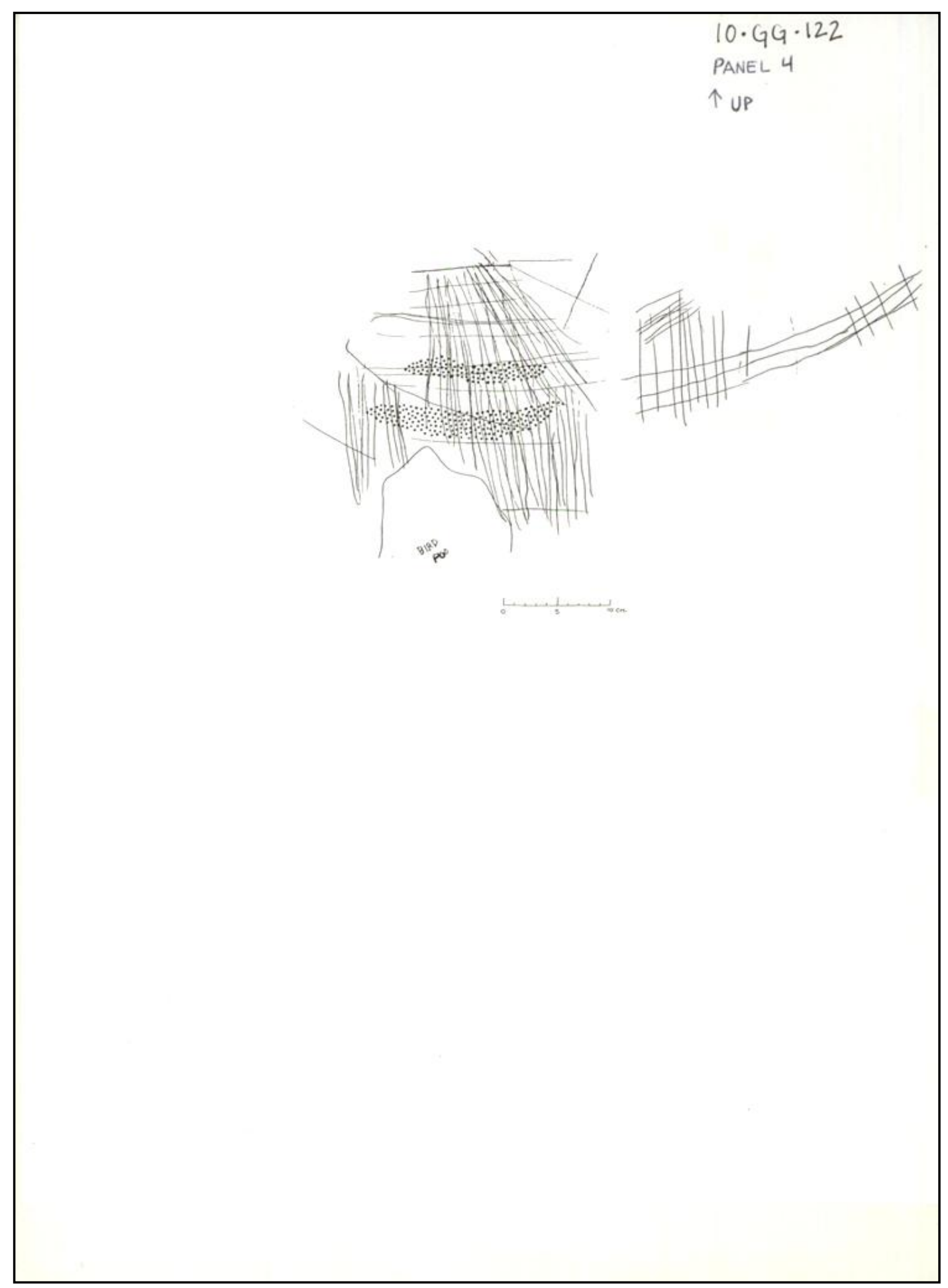

Figure A.65. 10GG122, panel 4. 


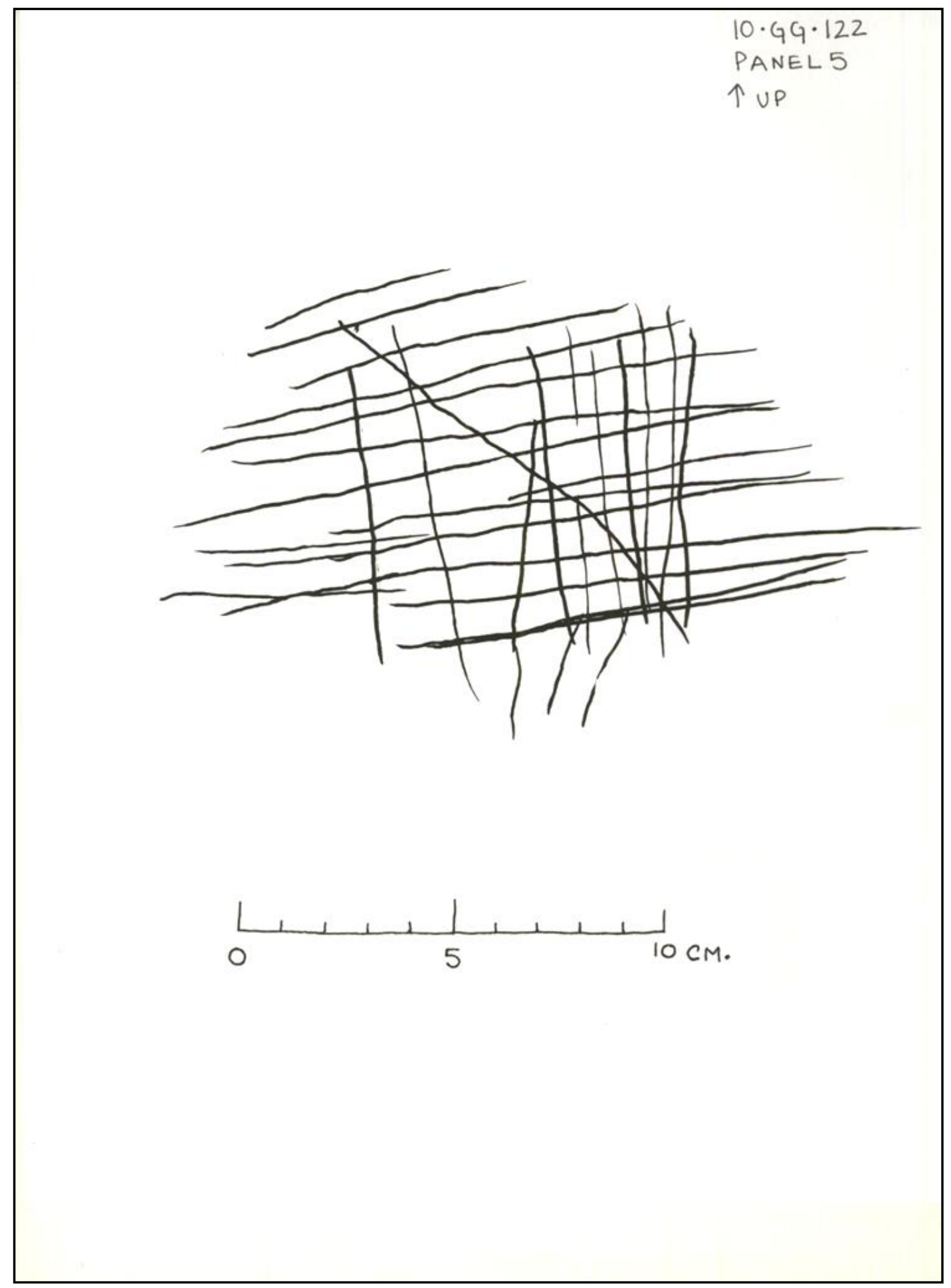

Figure A.66. 10GG122, panel 5. 


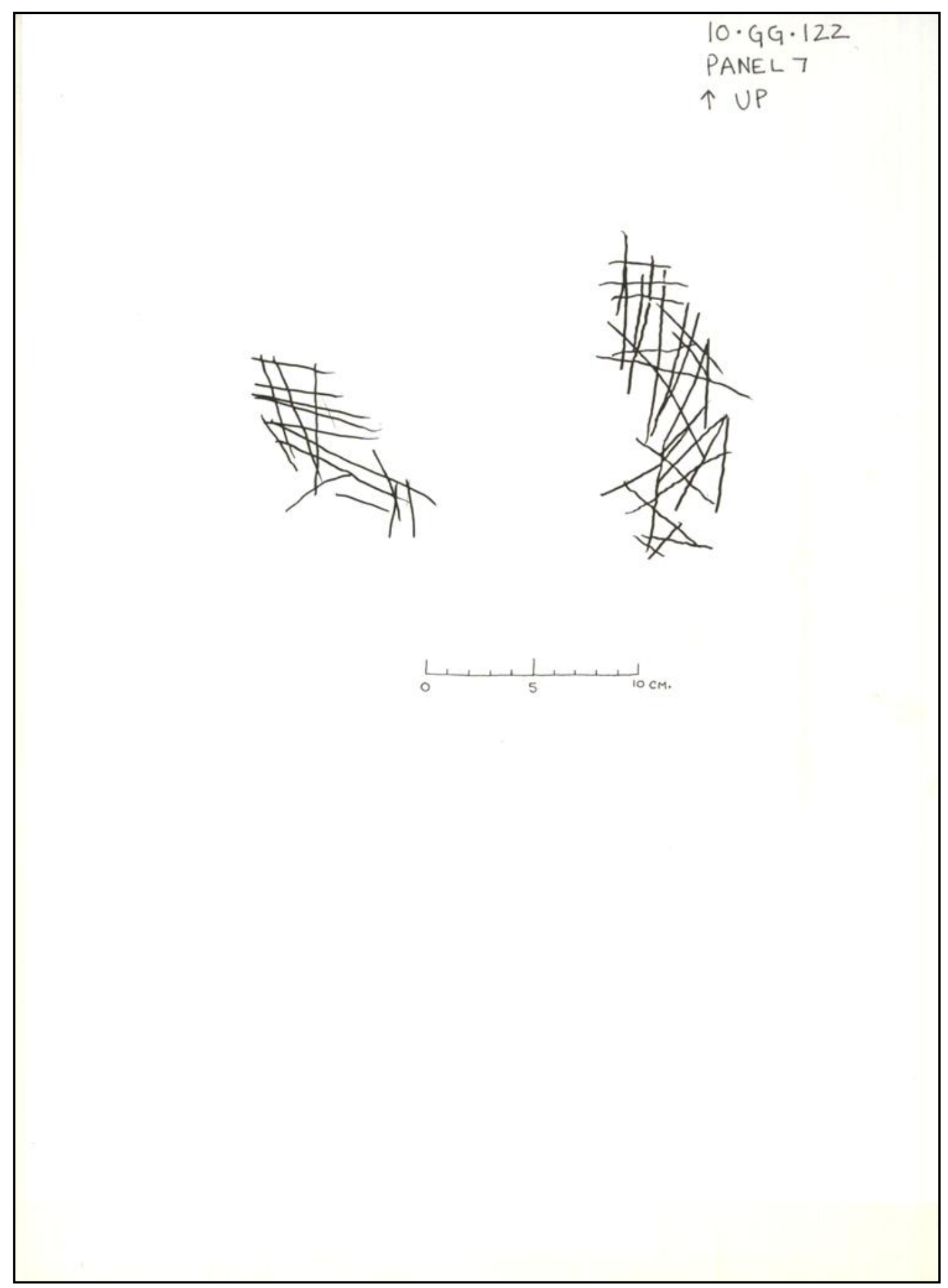

Figure A.67. 10GG122, panel 7. 


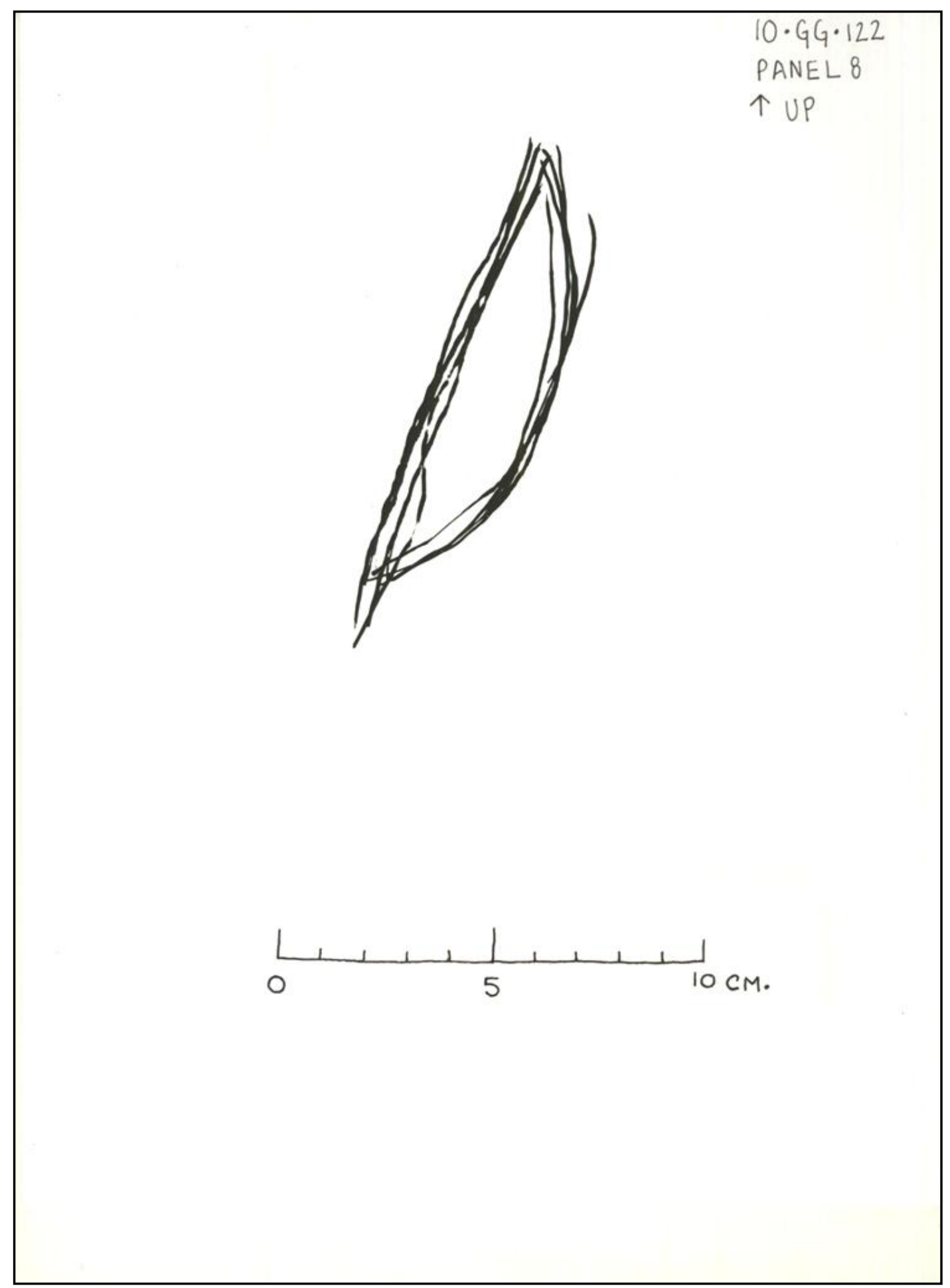

Figure A.68. 10GG122, panel 8. 


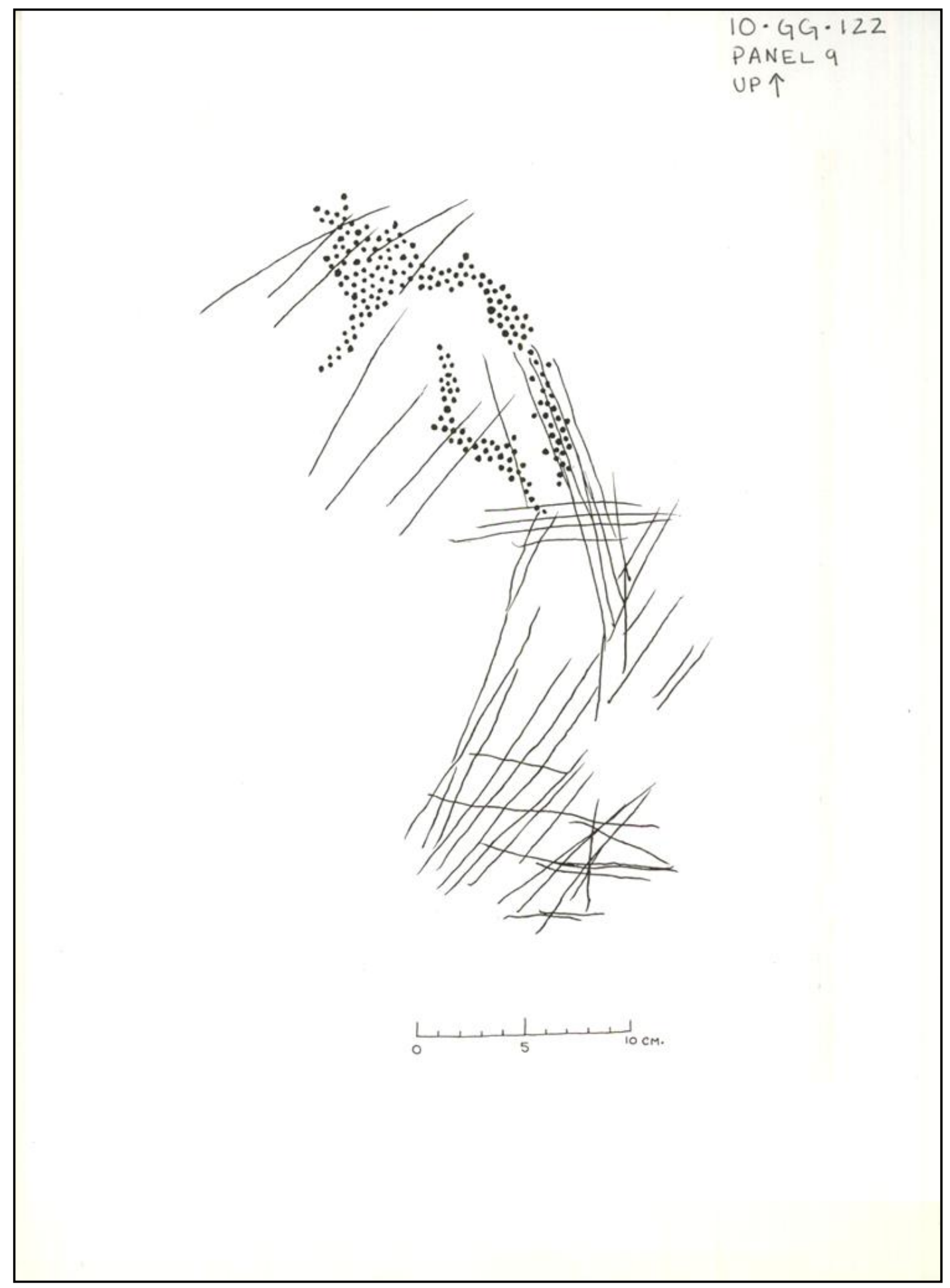

Figure A.69. 10GG122, panel 9. 


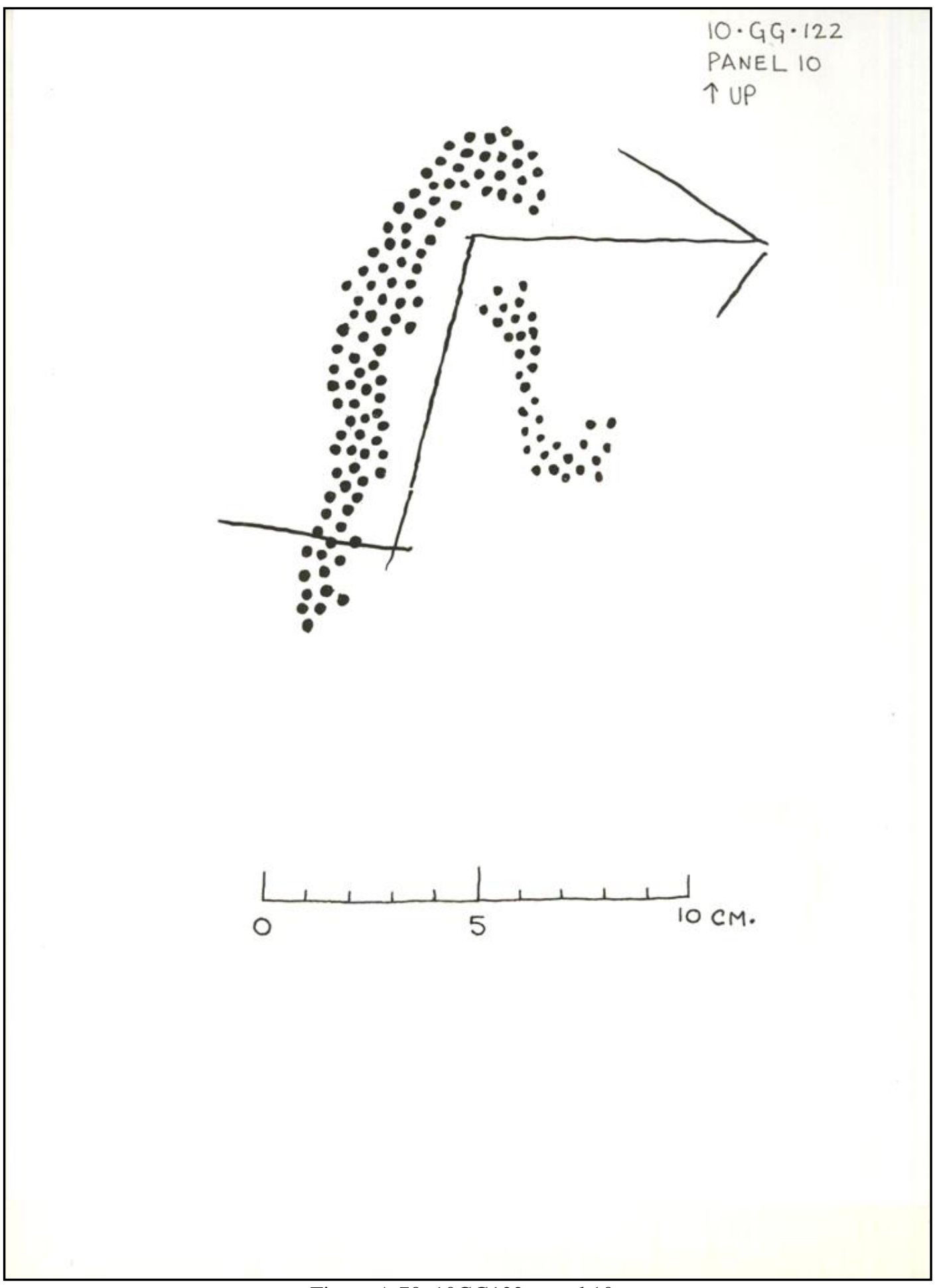

Figure A.70. 10GG122, panel 10. 


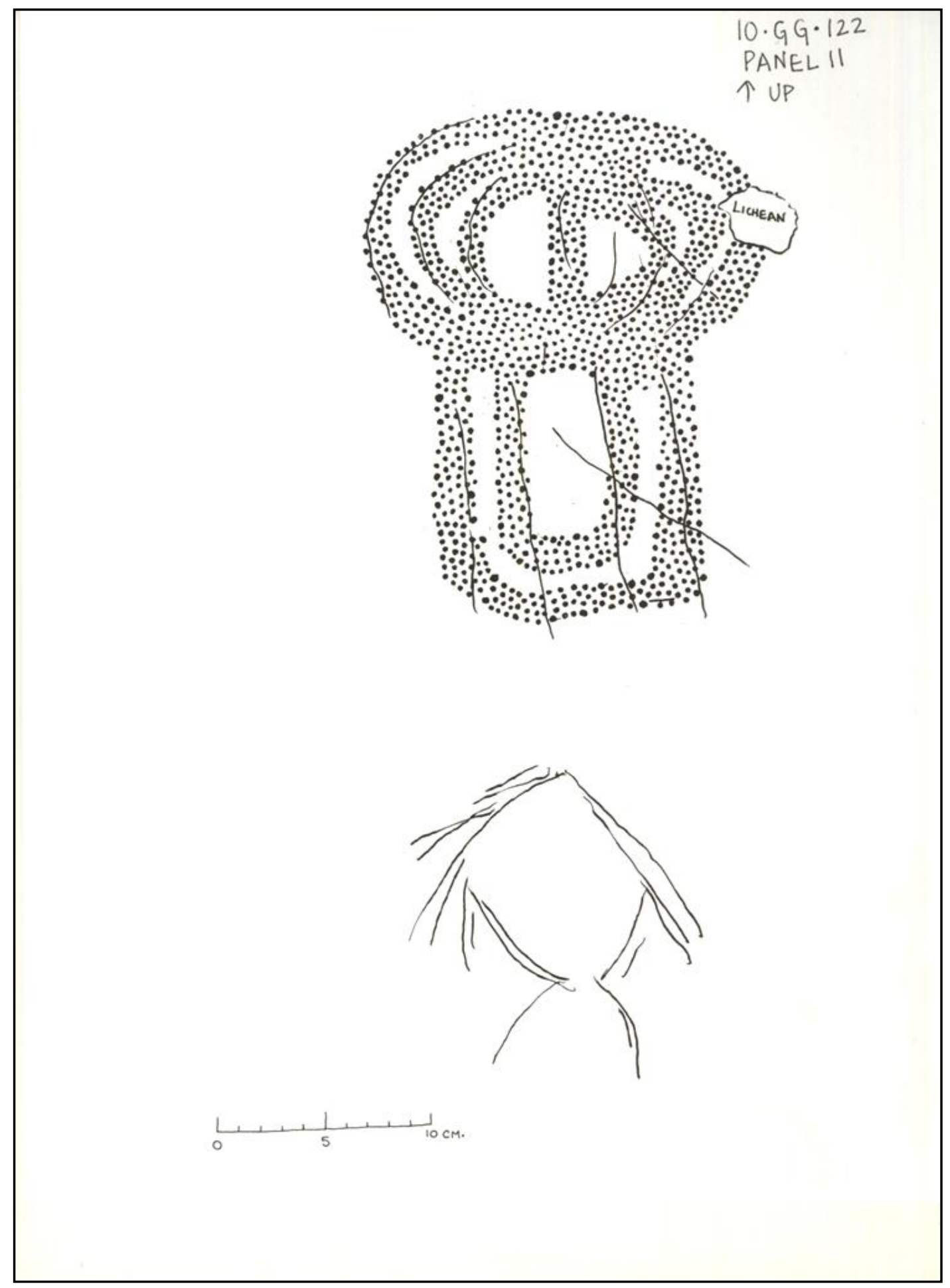

Figure A.71. 10GG122, panel 11. 


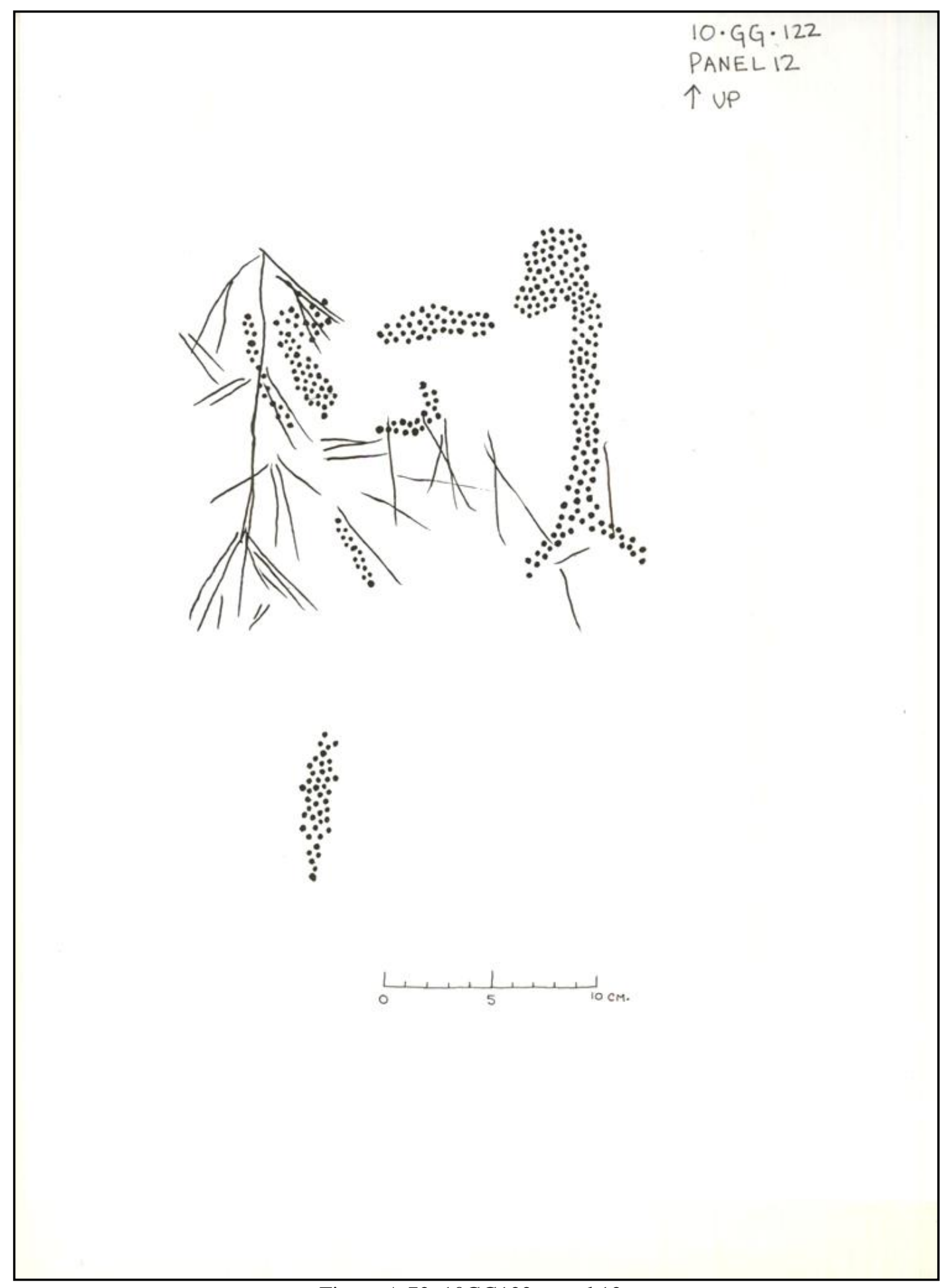

Figure A.72. 10GG122, panel 12. 


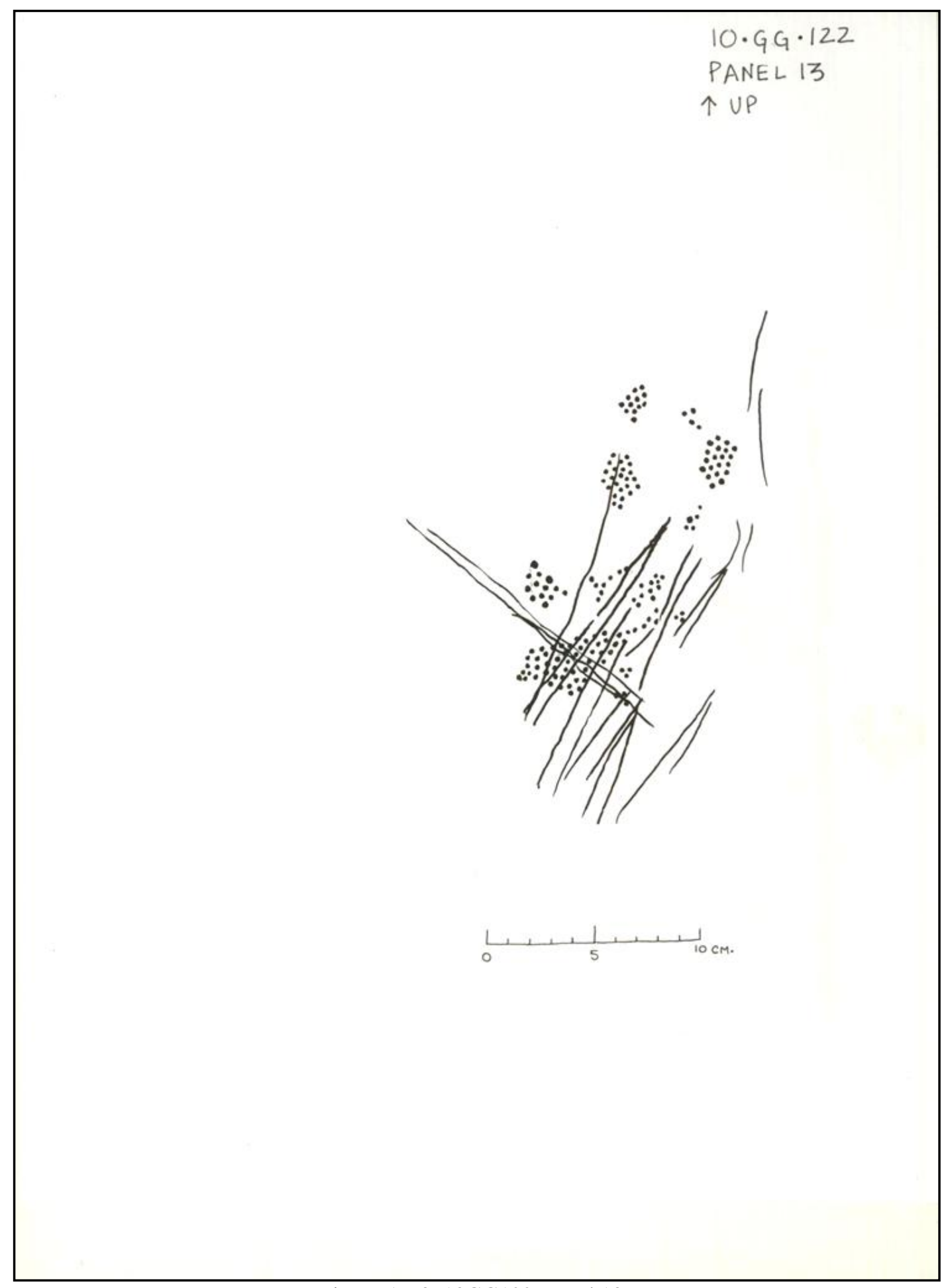

Figure A.73. 10GG122, panel 13. 


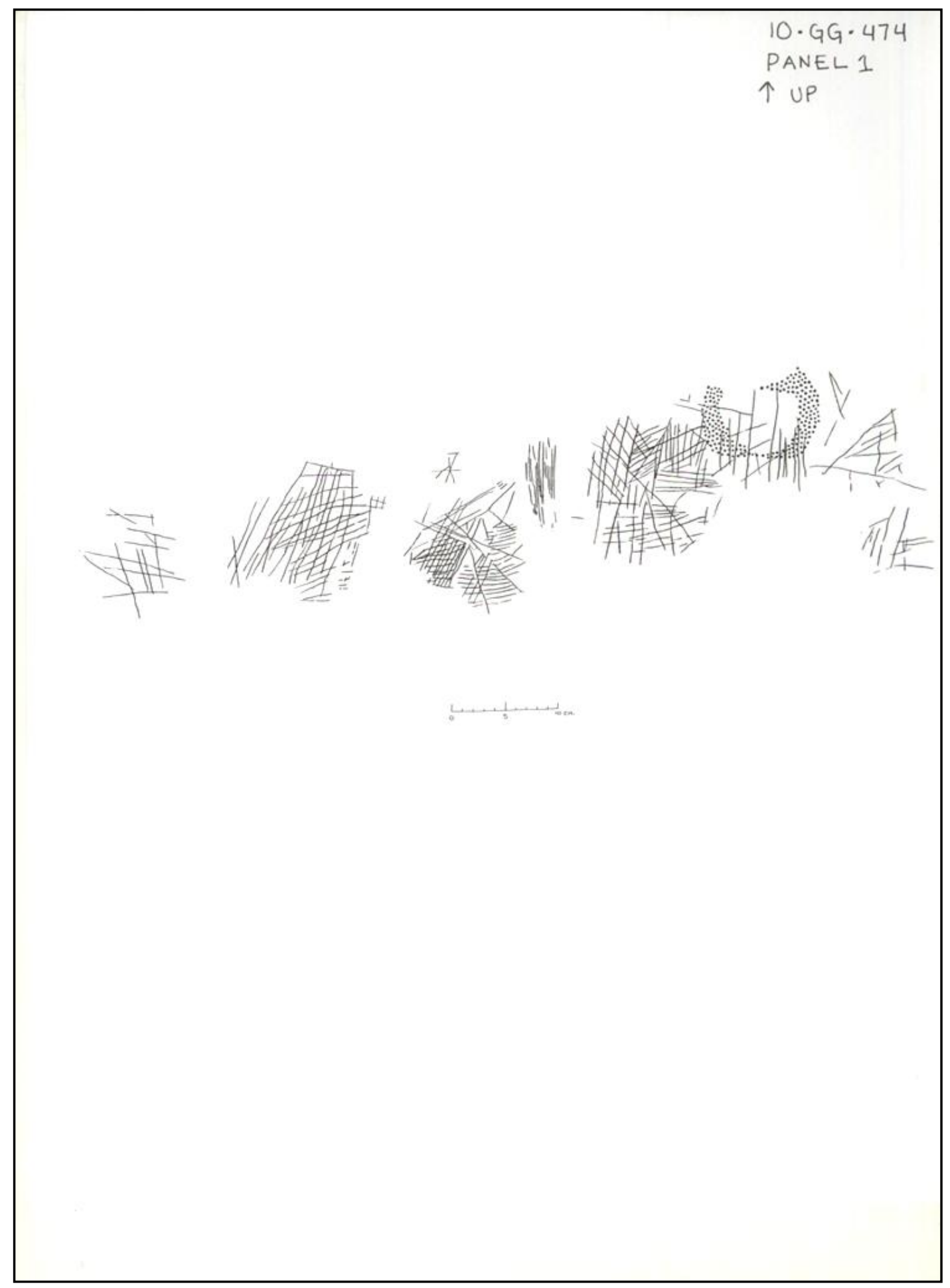

Figure A.74. 10GG474, panel 1. 


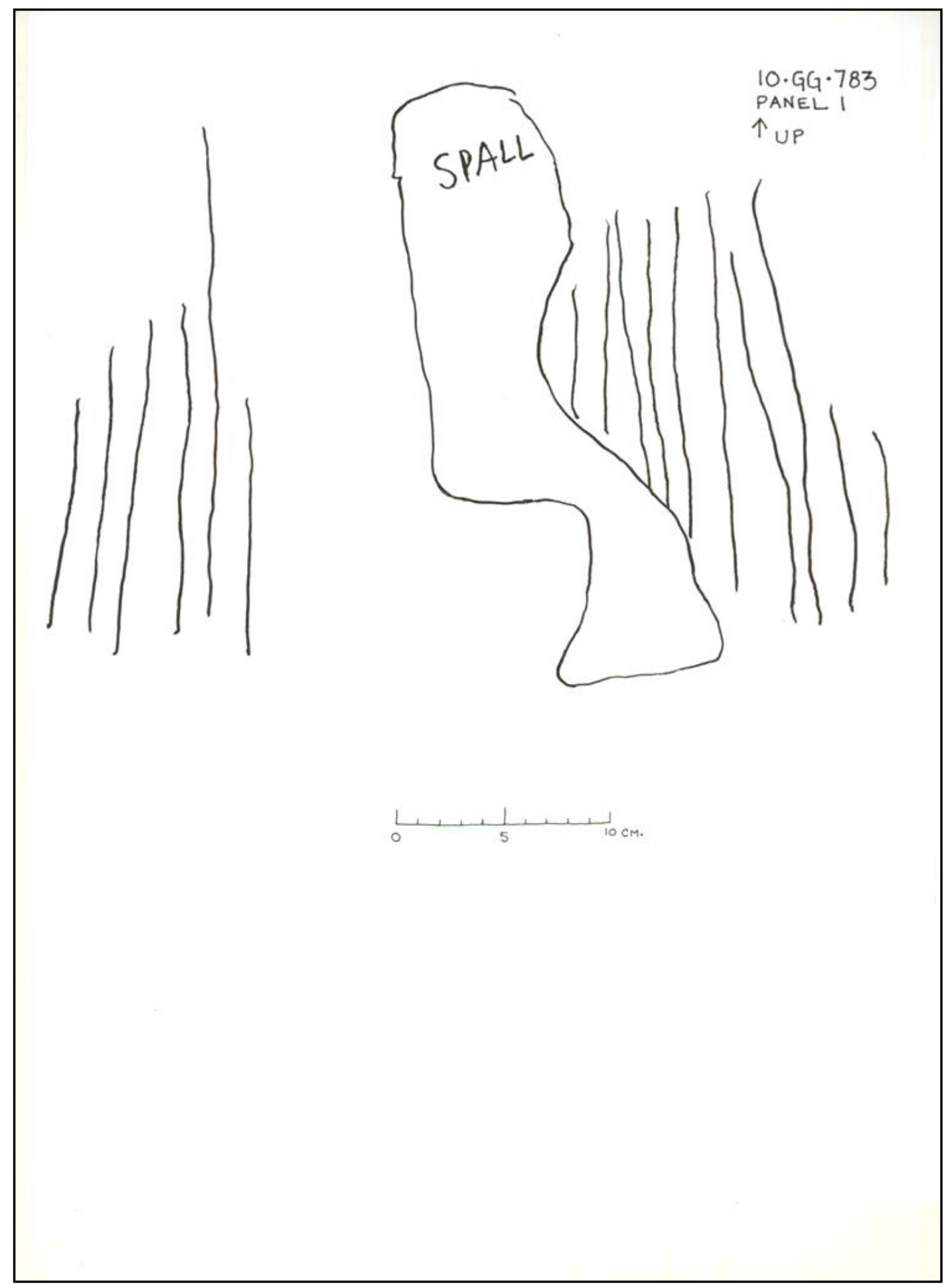

Figure A.75. 10GG783, panel 1. 


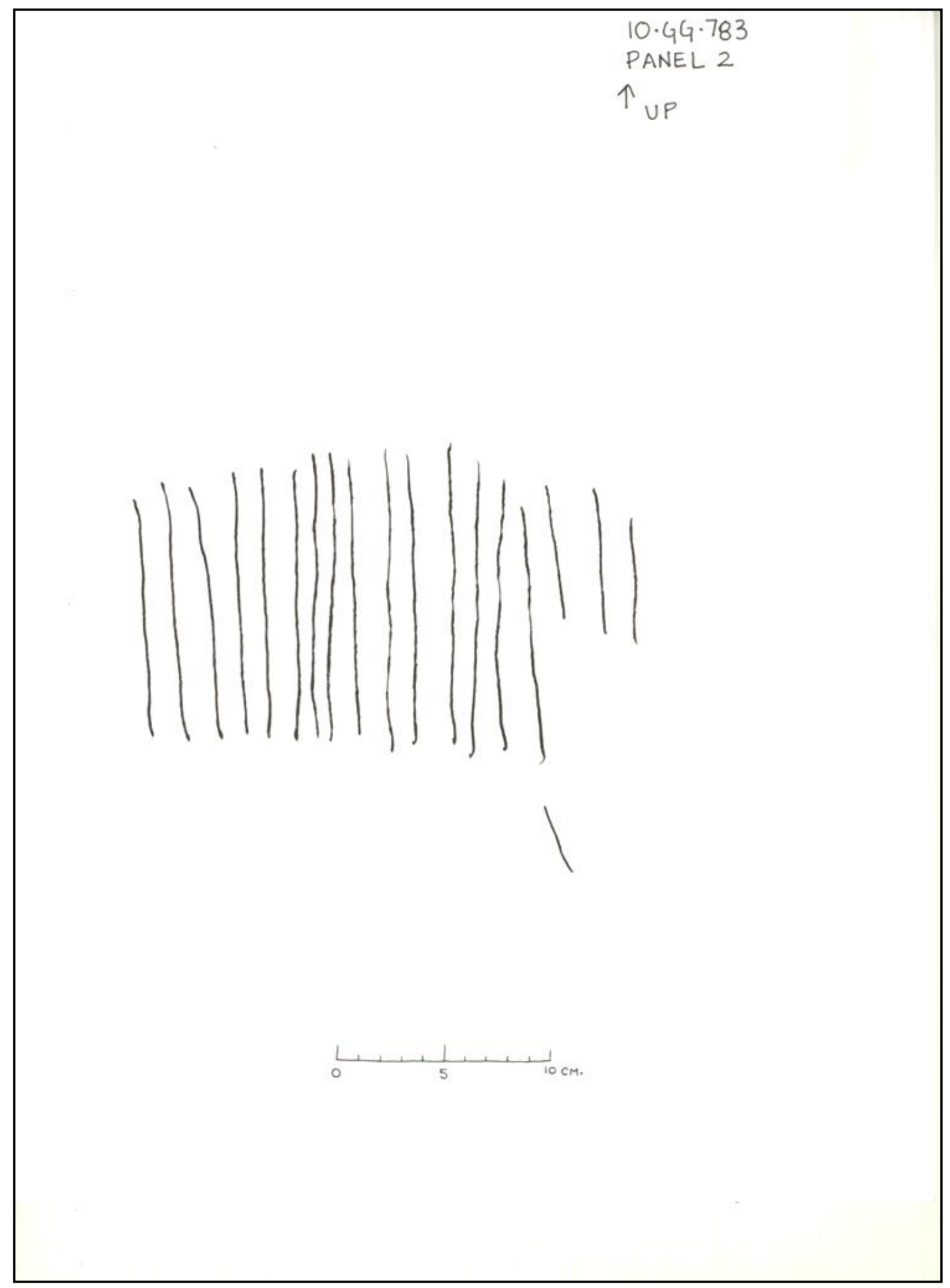

Figure A.76. 10GG783, panel 2. 


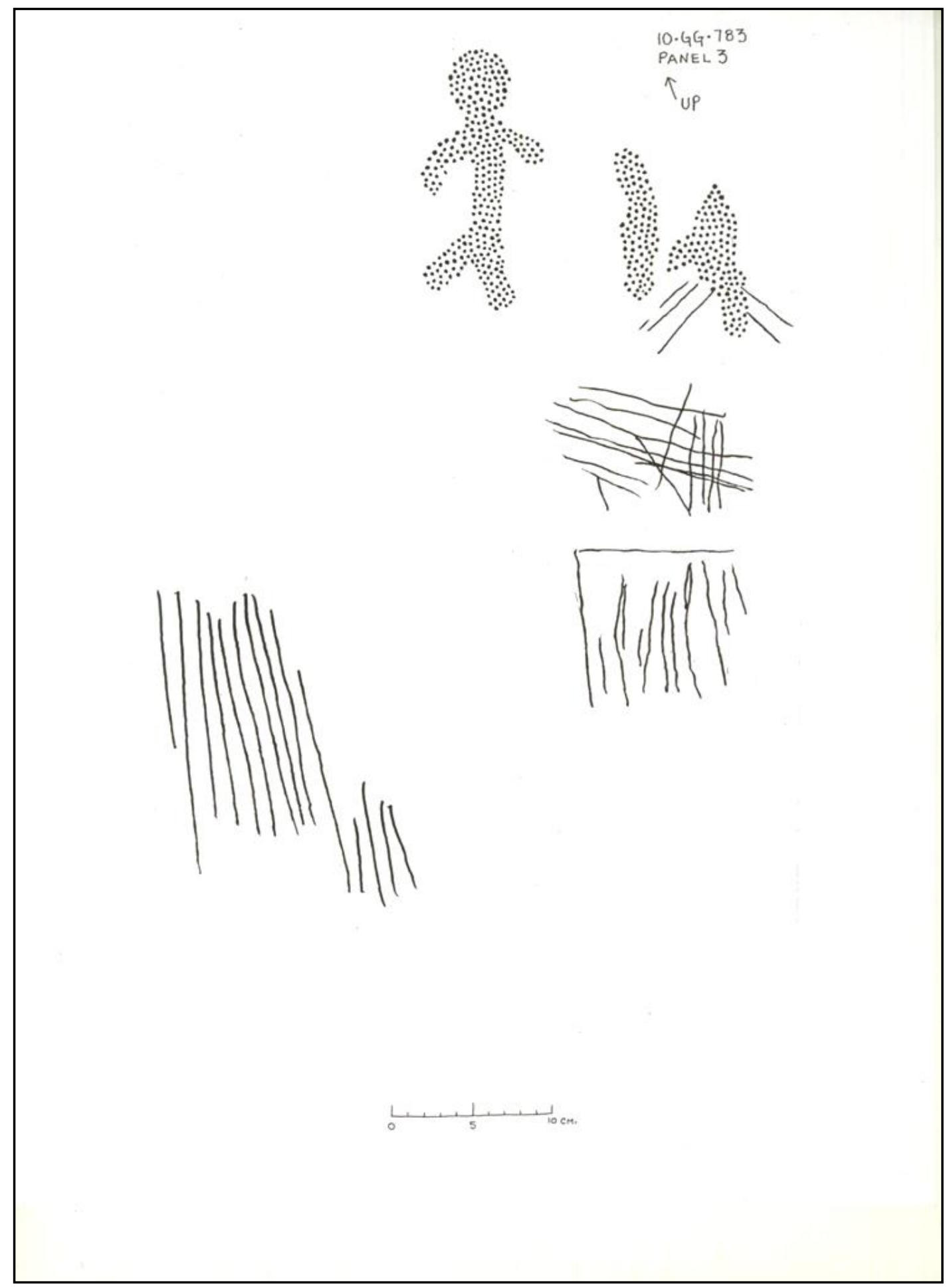

Figure A.77. 10GG783, panel 3 . 


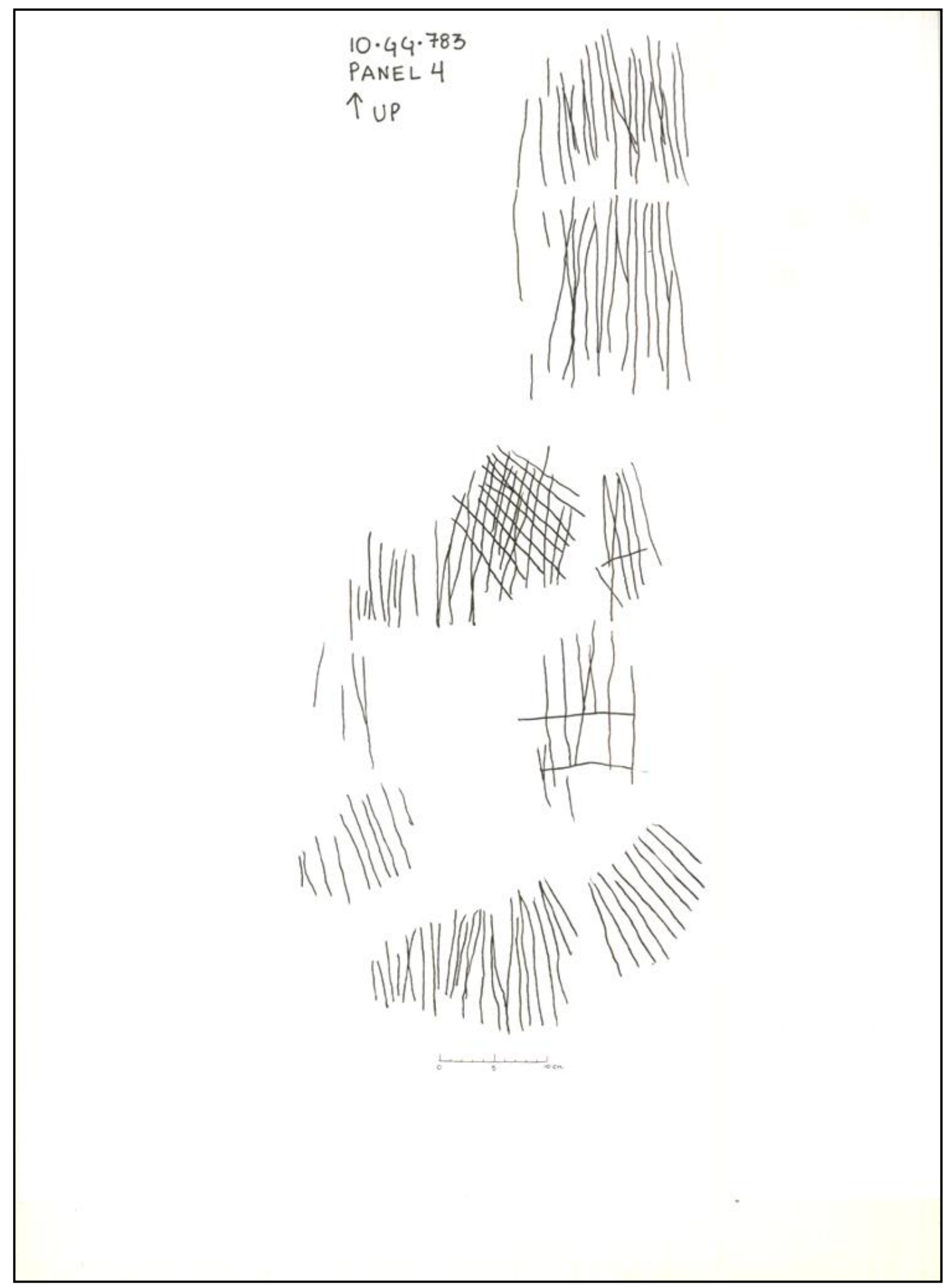

Figure A.78. 10GG783, panel 4. 


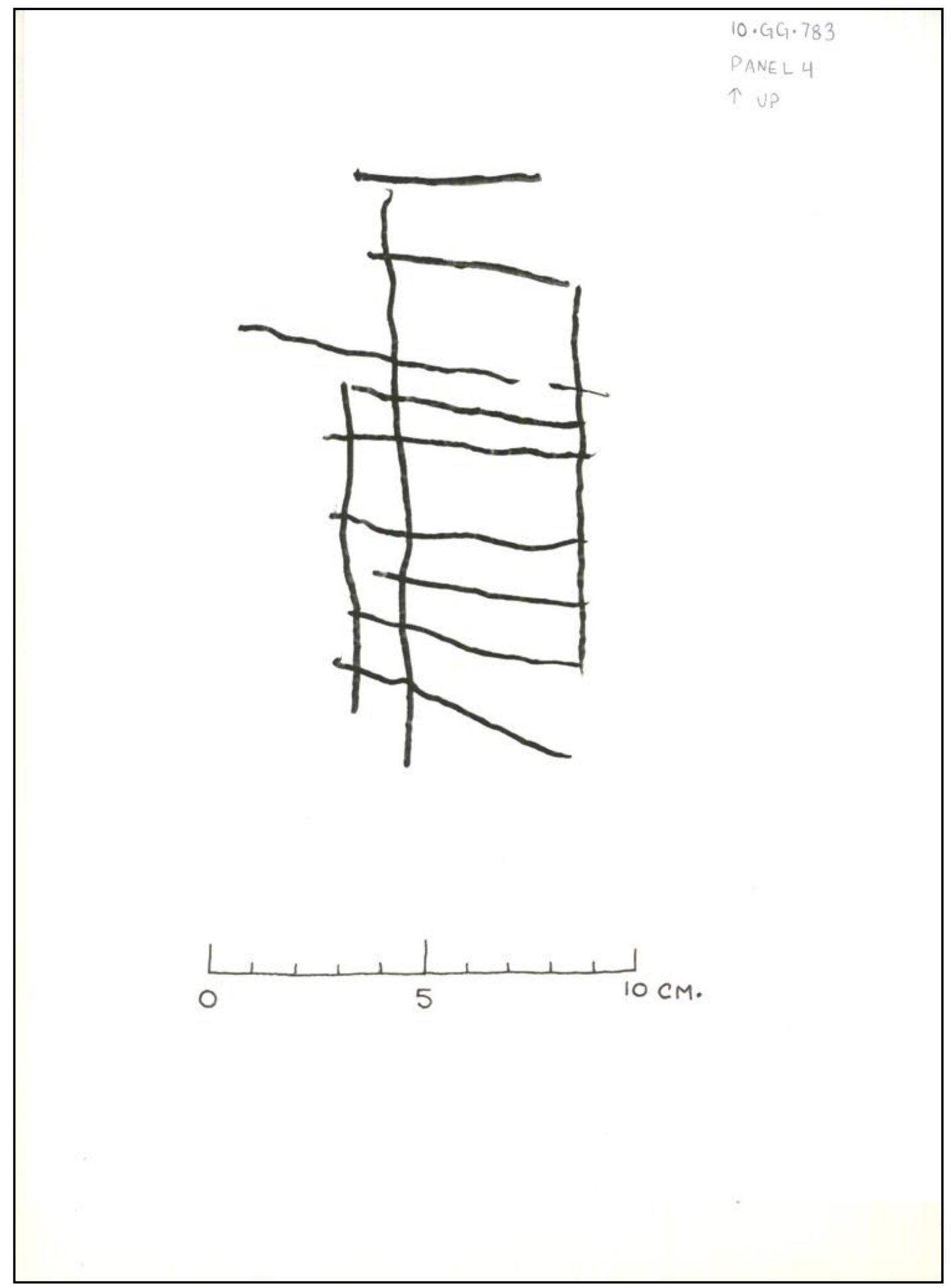

Figure A.79. 10GG783, panel 4. 


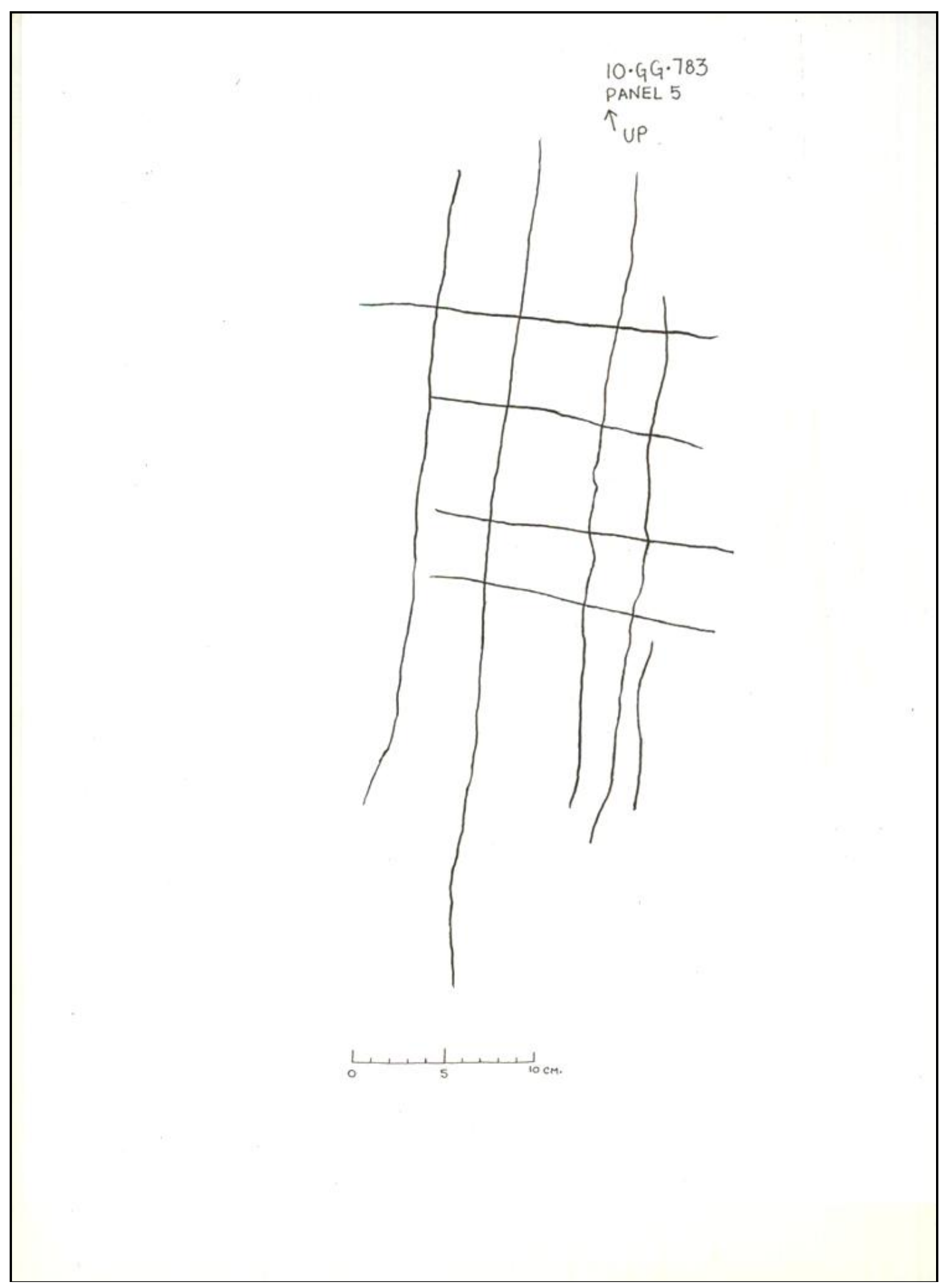

Figure A.10. 10GG783, panel 5. 


\section{Appendix B}

Scratched Petroglyph Survey Form 


\section{Scratched Petroglyph Survey Form}

\section{General Data:}

$\underline{\text { Site No.: }}$

Site Description:

Aspect:

Inclination:

Vandalism/Natural Defacement:

Artifact/Feature Association:

Panel Size / Scratched Petroglyph Size:

Free standing scratched motif or associated with another petroglyph:

Digital Photo No.:

UTM: N: $\quad$ E:

List other petroglyphs located on the same panel as the scratched petroglyphs:

Relative repatination between those petroglyphs listed above and the scratched petroglyphs:

The number of petroglyph at each site and how many of those panels contain scratched $\underline{\text { rock art: }}$ 


\section{Superimposition:}

Percentage of superimposition:

$100 \%$ superimposed

$<50 \%$ superimposed

$>50 \%$ superimposed

no superimposition

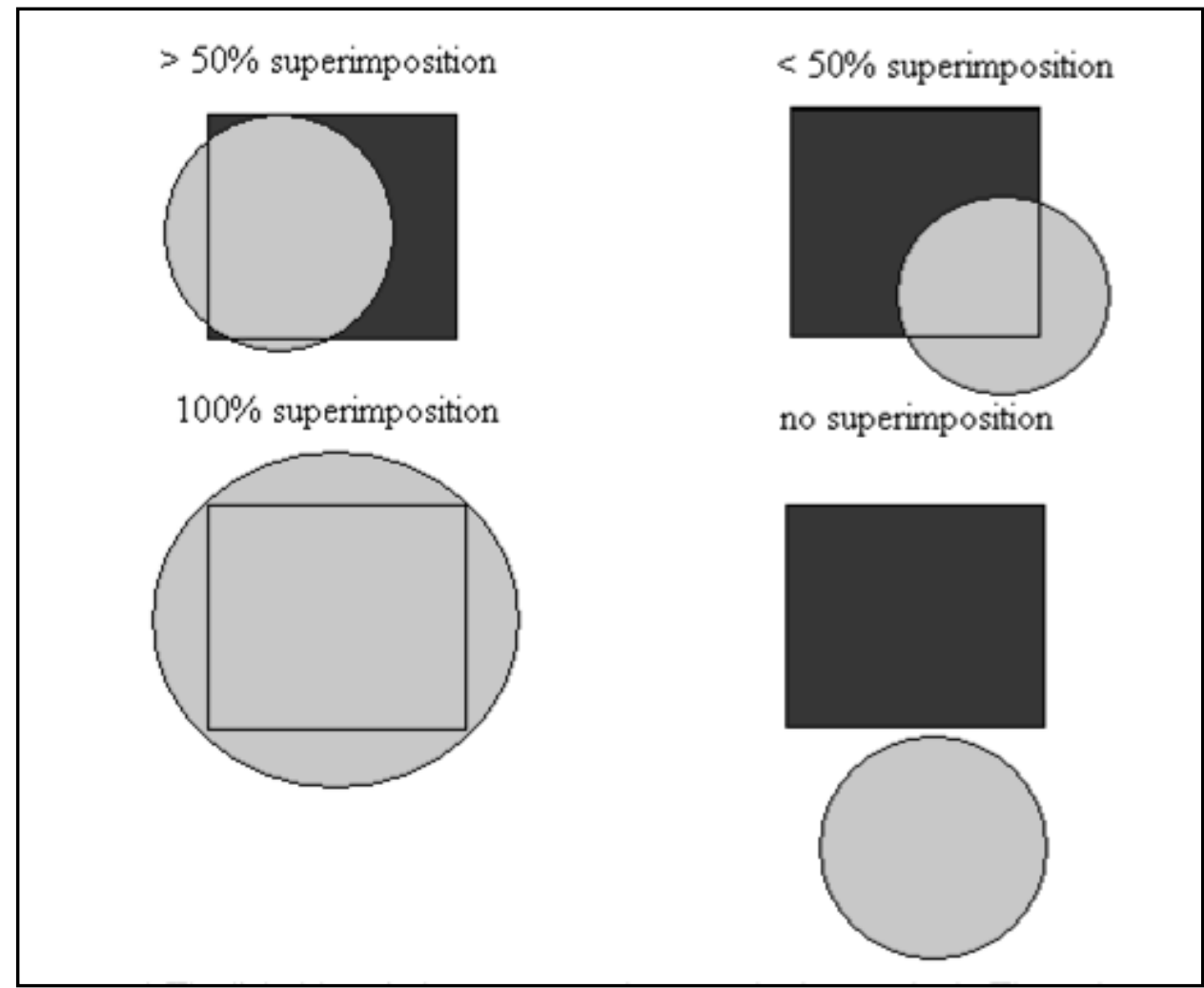

Figure B.11. Visual representation of superimposition percentages. The gray circle represents the scratched petroglyph the black square represents the abraded or pecked petroglyph.

$\underline{\text { Style and motif of "other rock art": }}$

$\underline{\text { Relative repatination: }}$

\section{Embellishments:}

Associated with an abraded or pecked motif (yes or no): 
Style and motif of associated petroglyph:

Description of association between scratches and abrasion or pecking (differentiate between an outline or embellishment):

Relative repatination:

Scratched preforms:

Associated with an abraded or pecked motif (yes or no):

Style and motif of associated petroglyph:

Description of association between scratches and abrasion or pecking (differentiate between an outline or embellishment):

Relative Repatination:

Motif (for comparison with mobile art):

Motif Type:

Scratched petroglyphs and quartz:

Quartz crystal located on site (as indicated by site form):

If yes, describe:

Quartz crystal located within a 10 meter radius of the scratched petroglyph?

If yes, describe:

Photo No.: 


\section{Appendix C}

Issues with Using Munsell Color Charts to Determine Relative Repatination Data Concerning Rock Art Superimposition 
There are several methods for dating petroglyphs. Relative dating methods using superimposition and repatination are the most commonly employed dating methods, and were applied during this research. Differences in the accumulation of rock varnish between scratched petroglyphs and abraded or pecked petroglyphs can be examined to determine a relative chronology. Rock varnish is a biogeochemical coating that develops over time on rock surfaces in arid regions and typically causes them to darken with age. An earlier petroglyph should have a darker accumulation of rock varnish than a later one. A Munsell rock color chart has been employed in the past (Ritter 1994) to define color variation in petroglyphs to estimate relative repatination. On rock art panels containing more than one petroglyph motif, each motif is assigned a color using the Munsell rock color chart. The assigned colors are then compared to establish which petroglyph is darker and thus older than the lighter and younger petroglyphs. Relative dating using superimposition is based on the assumption that if one rock art motif is placed over another then the bottom motif is older than the one on top.

A Munsell rock color chart was used to measure relative accumulation of varnish to determine if scratched petroglyphs are contemporaneous, earlier, or later than associated pecked or abraded petroglyphs. During fieldwork a number of issues arose with this method. Applying the Munsell rock color chart to measure relative accumulation of varnish has significant room for error.

This method is dependent on the assumption that both the scratched and abraded or pecked petroglyphs penetrated the varnish at the same depth. However, scratched, abraded, and pecked petroglyphs do not appear to penetrate the varnish at a consistent 
depth. Occasionally, scratched petroglyphs only lightly penetrate the varnish. This may result in a darker base color than a pecked petroglyph that fully penetrates the varnish. If the petroglyphs do not penetrate the rock varnish at equal depths, then it is not safe to assume that lighter petroglyphs are younger and darker petroglyphs are older. The petroglyphs in the Bennett Hills do not appear to penetrate the rock surface at consistent and equal depths. This generates a significance source for error.

Another source for error in measuring relative accumulation of varnish using the Munsell rock color chart is variation in color between rocks. There is considerable variation in the color of the rocks and the varnish between petroglyph panels. Due to inconsistencies in color one could not compare relative accumulation of varnish data between two or more petroglyph panels. Relative accumulation of varnish would only apply to the petroglyph motifs on a single rock art panel. For example, one could not say that the scratched motif on panel 1 is darker and thus older that the abraded motif on panel 2. These petroglyph panels may be on different types of rock, one being naturally darker than the other. The variation in darkness may be representing natural differences between the two rocks rather than variation in varnish accumulation.

It is also important to recognize that varnish can take a long time to accumulate. Even a period of 50 years between pecking and scratching would not be sufficient time to observe a difference between the color of varnish. Two petroglyphs may look the same color, suggesting the two motifs are contemporaneous but they may have been manufactured many years apart. 